
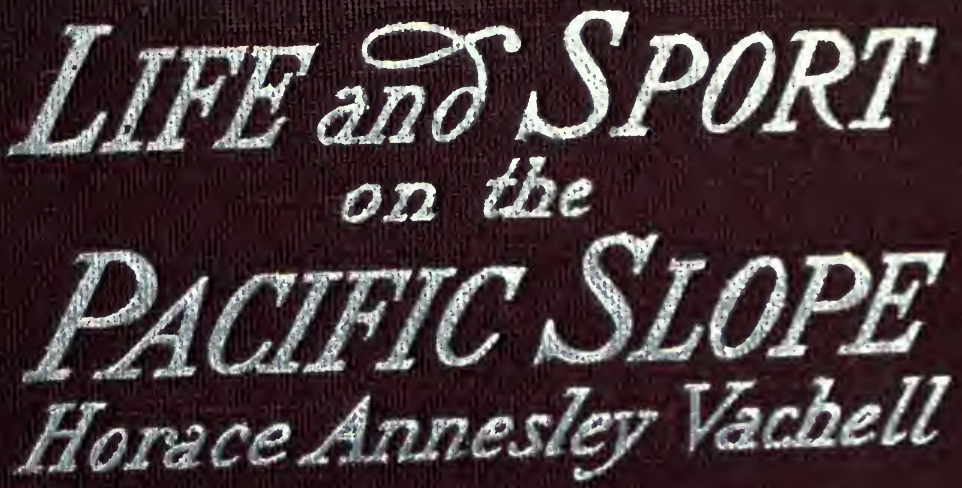


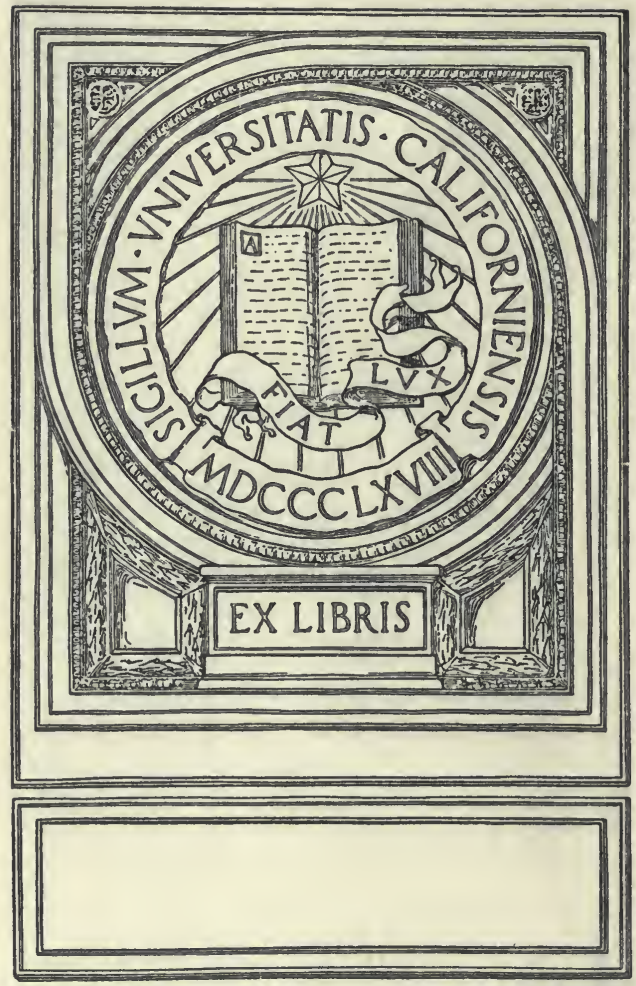




Digitized by the Internet Archive in 2008 with funding from Microsoft Corporation 



\section{Life and Sport on the Pacific Slope}






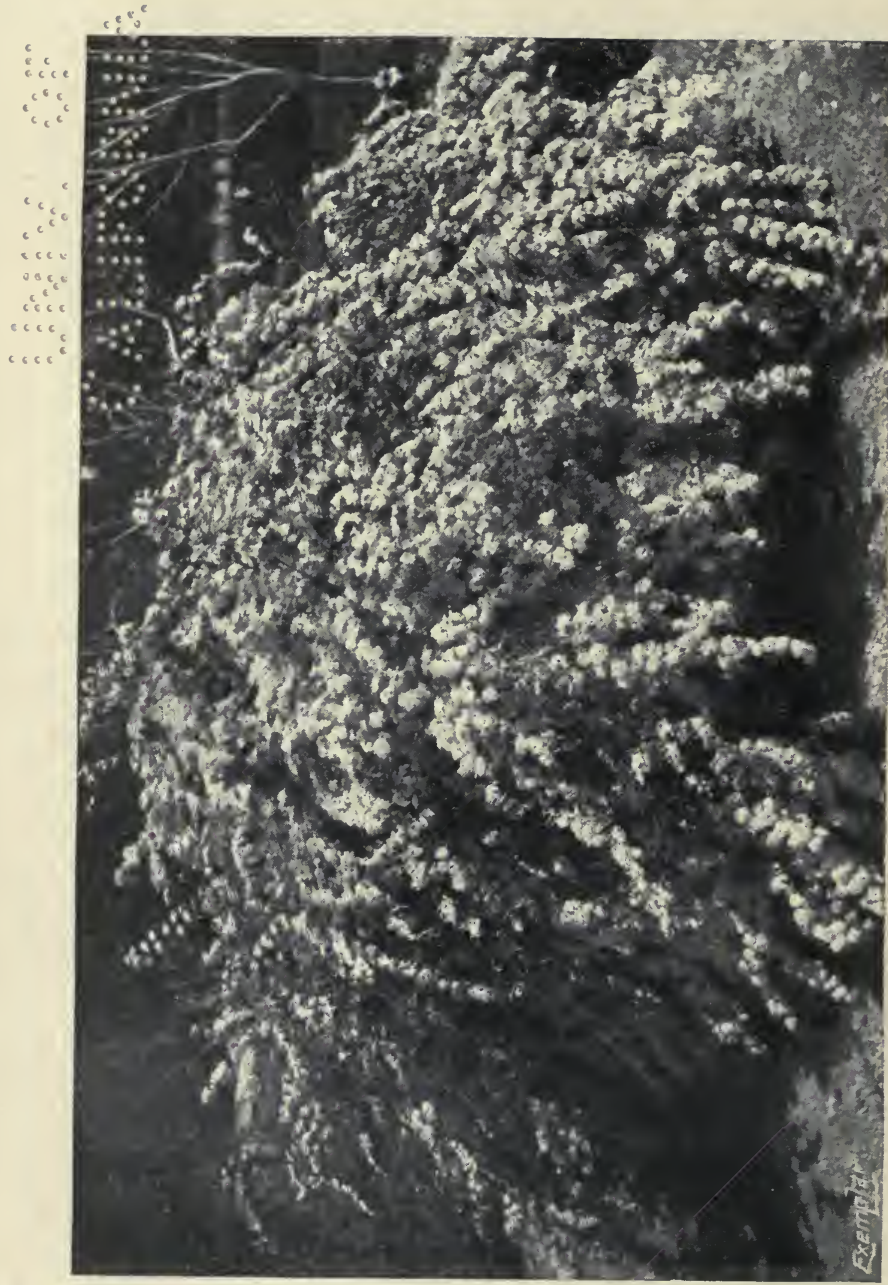




\section{Life and Sport on the}

\section{Pacific Slope}

By

Horace Annesley Vachell

Author of "The Procession of Life," "A Drama in Sunshine," etc.

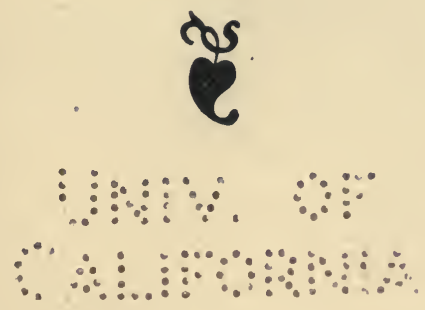

New York

Dodd, Mead and Company

I 90 I 
Copyright, 1900 By Dodd, Mead and Company All rights reserved

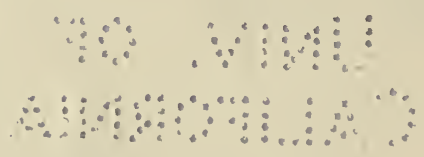


TO

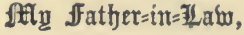

\section{CHAUNCEY HATCH PHILLIPS,}

\section{WHO, BORN IN THE EAST, IS ESSENTIALLY OF THE WEST,} I DEDICATE THIS BOOK. 



\section{Prefatory Note}

Mr Dear ChIef, - I dedicate this book to you with profound pleasure, in acknowledgment of an affection and sympathy which have been sealed by a great sorrow. From your hands I received a loyal, loving wife; but the fact that she was born in California has not shackled my lips in speaking of the West. She, I know, would have entreated me to write with a free hand; and if at times I seem to criticise somewhat harshly certain women who, consciously or unconsciously, are widening the gulf between their husbands and themselves, let it be remembered by my friends that I have judged these women according to a standard set by a daughter of the West, a standard of tenderness, fidelity, unselfishness, and modesty to which few wives, be their country what it may, can attain.

Many and many a time have you and I talked orer the subjects treated in these pages; but 


\section{viii}

\section{Prefatory Note}

although our opinions clashed now and again, our intercourse continued absolutely free from friction and discord. That intercourse, which began seventeen years ago, and our friendship, which sunshine could not wither nor shadow obscure, have indirectly inspired this volume. But I ask you to shoulder no responsibility in regard to it; and whether you approve what I have written or not, believe me,

Most affectionately yours,

Horace Annesley Vachell.

Hursuex, Winchester. 


\section{Contents}

CHAPTER PAGE

I. ThE LAND OF To-MORROW . . . . . . 3

II. The Men of The West • • . . . . 23

III. The Women of The West . . . . . 49

IV. The Children of the West • . . 73

V. Ranch IIfe, I. • • • • • • • • • . 91

VI. Ranch LIfE, II. . • . • • . . . 107

VII. Business LIFE • • • . • . . . . . 131

VIII. Anglo-Franco-Californians . . . 149

IX. The Englishman in the West, I. . . 161

X. The Englishman in the West, II. . 177

XI. The Side-Show . . . . . . . . 191

XII. Pot-pourri • • . . . • • . . 205

XIII. EThical • • . . . . • . . . 229

XIV. Big Game Shooting . . . . . . . 243

XV. Small Game Shooting, I. . . . . . 273

XVI. Small Gamf Shooting, II. • . . . 289

XVII. Sea Fishing • • • • • • • • • 507

XVIII. Fresh Water Fishing . . . . . 335 


\section{APPENDICES}

CHAPTER

I. A Few Statistics . . . . . . . . 347

II. Horticulture •. . . . . . . . 360

III. Viticulture . . • . • . . . . . . 369

IV. Beet Culture . . . . . . . . . 375

V. IrRigation • • • • • • . . . . 378

VI. Hints to Sportsmen . . . . . . 385 


\section{I \\ THE LAND OF TO-MORROW}





\section{Life and Sport on the}

\section{Pacific Slope}

\section{I}

\section{THE LAND OF TO-MORROW}

$\mathbf{N}^{\mathrm{OT}}$ long ago I saw the sun rise in a Surrey 1 garden. Standing at an open window I looked down upon dew-laden, silvery lawns that sloped to a lovely mere. In the mid-distance the mist lay like a velvety blur upon the woods skirting the northern bank of the Thames. It veiled, too, the great cedars and elms in the garden, robbing them of colour and substance, so that they seemed, as it were, grey ghosts, - spectral sentinels of an Eden whence the glory had departed. The mist began to melt beneath the kiss of an August sun, and I lingered at my window, waiting expectantly for what would be revealed, as if I were a stranger to the garden and its beauties. Very soon the trees and shrubs and flowers were clearly defined, fresh and glowing. Against the yew hedge that encompassed this pleasaunce was an herbaceous border. Here, great salmon-pink hollyhocks towered above the graceful larkspurs - dark and pale blue. Below these again were those sweet vagabonds the cornflowers, the stocks, the verbenas, and snapdragons. 


\section{Life and Sport on the Pacific Slope}

Fringing the border were the gaudy calceolarias. Not for the first time I was struck by the amazing finish of the picture, its exquisite texture and quality. And I reflected that in Surrey alone there are hundreds of such gardens, and that they represent the care and the culture of a thousand years.

Looking at this perfect miniature I was fain to contrast it with a picture I knew and loved in ancthis land seven thousand miles away. I could see in fancy a great valley sloping westerly to a great ocean. Upon the face of this landscape lay the same glad freshness of morning. And here too the mist had spread her magical carpet, obscuring the bare plains, veiling the rude houses and barns, blotting out, in fine, the works of man while lending unearthly beauty to the works of God.

In both pictures was revealed the hand of the Master. And the less included the greater, even as the infinite spaces of the sky are reflected in a dewdrop.

The Surrey garden was an epitome of yesterday and to-day. Upon the other, the great valley sloping to the Pacific, broods the promise of to-morrow.

This Land of To-morrow includes within itself the material resources of all the nations. It has a great seaboard, rich valleys, mountains of minerals, vast forests, rivers, lakes, reservoirs of oil (the fuel of to-morrow), and a people not to be matched in energy, patience, pluck, and executive ability.

Fifty years ago this was the Lotos Land, where life was essentially Arcadian, pastoral and patriarchal. Another race dwelt upon the shores of the 


\section{The Land of To-Morrow}

Pacific, the Hispano-Californians, who ate and drank and made merry. Some of them may still be found south of Point Concepcion; they have absolutely nothing left - except their charming manners. When I came to the Pacific Slope, in '82, you might find, here and there, a ranchero, the lord of many acres, of many flocks and herds. At his house a warm welcome awaited the stranger. The men of the family, the caballeros, entertained their guests with feats of horsemanship, barbecues, and stories of the past. The señoritas danced and sang. The word "work" was seldom mentioned. These were simple primitive people: content with little, grateful to God for the blessings vouchsafed them, truly free, if we may accept their own testimony, and truly happy. Such as they were, however, the Pacific Slope will never see their like again.

Their songs, I remember, were infinitely tonching. One had a pathetic refrain (it was a favourite with the señoritas): Adios, adios, para siempre adios. I never heard it sung without reflecting that this so to speak - was the swan-song of the Latin to the all-conquering Anglo-Saxon.

During the fifty years that followed the American occupation of the West so much has been accomplished that an encyclopedia would hardly find room for facts. In the appendices of this book will be found figures taken from reliable sources that will serve to faintly indicate what has been done. By applying to these figures the rule of geometrical progression some conception may be formed of what will be done - to-morrow.

It will be-conceded, I think, that so far as Cali- 


\section{Life and Sport on the Pacific Slope}

fornia, Oregon, Washington, and British Columbia are concerned the experimental stage has been passed. Mining, for instance, has become an exact science. The same may be said of fruit culture, viticulture, the breeding of fine horses and cattle, the making of wine and oil, cereal-raising, and manufactures. The cruiser upon whose bridge stood Admiral Dewey when he entered the harbour of Manila was built in San Francisco. An immense battle-ship, "The Oregon," doubled Cape Horn without misadventure, a marvellous feat. Her keel was laid in the ship-yards of the West. The modern war ship is a machine so complex, combining in itself so many of the arts and sciences, so incomparably difficult of nice adjustment, that it would seem to be the ne plus ultra of human ingenuity and mechanical skill. To the hands and brains that have constructed an "Oregon" nothing can be deemed impracticable.

I shall now set forth, as briefly as may be, my reasons for speaking of the Pacific Slope as the land of To-morrow. The people who live in the West are profoundly convinced that their country is a land of to-day. More, the word "to-morrow" has an offensive signification. California, for instance, was once known as the land of "mañana," a land where nothing must be done to-day that could possibly be put off till to-morrow.

Time has brought many changes to the Pacific Slope, but none more amazing than the change from ignorance and indolence to activity and intelligence. But the promise of the future dwarfs the performance of the present. Heretofore, despite her unpar- 


\section{The Land of To-Morrow}

alleled resources, California has been, for the many, terra incognita. Over and over again I have been asked the most absurd questions. A lady of rank and fashion told me only the other day that she hoped to visit California, because she wished to see the - Andes. Another thought that the Golden State belonged to England. A third was interested in Yo Semite, but feared the terrors of the wilderness. She really believed that I roamed my ranch clad in skins of wild beasts, that the plains were black with Apaches, the towns at the mercy of desperadoes! Some of my friends have greeted me on my return to England as if I were a long lost explorer. "How glad you must be," they say, holding my hand in a fervent clasp, "to find yourself once more in a civilised country." When I explain that I have been living in a town of thirty thousand people, a town better lighted, better kept, more abundantly blessed with the amenities of life, than two-thirds of the cathedral towns of England, I am confronted by a pitying stare.

I remember taking some English travellers to a luncheon at the country house of a Californian. After luncheon a drag came round, and we went for a drive. The visitors cocked bewildered eyes at the coach, the harness, the servants, the horses. When their surprise found words, they overwhelmed our host with compliments far too florid for his taste. Silence would have been a subtler form of commendation. French visitors would have conveyed their sense of pleasure and concealed their amazement.

But this ignorance of the West is passing away, and with it will pass the fear also, that fear which 


\section{Life and Sport on the Pacific Slope}

a great raw boy so often inspires in his elders. In a certain sense the West has been running amok. It has had a stormy youth. It has played queer pranks. Talk to the wise men of the East - why is wisdom supposed to dwell in the East? - and they will shake their hoary heads at the mere mention of the West. Some of them, doubtless, have suffered real pain, finding themselves in the grip of a young giant unconscious of his strength. Gold has come out of California and been sown broadcast all over the earth. There is no advertisement like gold. Even wise men are dazzled by the sight of it. And accordingly the very name of California became a synonym of the precious metal. Men who were unwilling to leave their snug hearths sent some of their savings to the State that was called golden. And it is to be feared that these savings were never seen again. In Wall Street, in the city of London, on the continental bourses, Californian mining stocks were freely bought and sold. But, for the most part, the great fortunes were made by the Californians themselves: the Fairs, the Floods, the Mackays, of bonanza times. The outsiders, who-like Kipling's woman - did not know, who never could know, and did not understand, lost their money and with it their faith in the El Dorado on the shores of the Pacific. Although gold was being taken by the ton from the mountains and streams, although the country was extraordinarily prosperous, yet the bottom - as the phrase runs - was out of the boom. California had the whooping-cough.

The measles followed in due course. In mining times, land was held at a few cents an acre. The 


\section{The Land of To-Morrow}

dons who owned hundreds of leagues were in the habit of giving it away. A miner, shrewder than his fellows, asked Mariano Vallejo for a farm. Vallejo gave him eight thousand acres of fine land, and bade him take more if he wanted more. Others followed. The Haggins, the Tevises, the Millers acquired principalities for a song. When the psychological moment came, these vast ranchos were subdivided and put on the market, on the world's market. Mr. Nordhoff wrote a book about California that was widely read. Pamphlets, maps, special editions of newspapers, lecturers, agents of the transportation companies, Boards of Trade, proclaimed the virtues of Californian soil. Of course, the facts, quite amazing enough in themselves, were embellished. It was a day of individual successes. One man had cleared four hundred pounds sterling from one acre of cherries! Another had made a fortune out of apricots, or oranges, or ostriches. Not a word was said of the patience, labour, and special knowledge that had made such results possible. Reading the pamphlets one was not only assured of success, but failure was proved to be impossible. The prose, in which these alluring statistics were embalmed, was homely enough, mere fustian, but the poetry that lay between the lines of it might have lent enchantment to a dustbin. Great stress was laid upon the climate. To the farmer in the East, or mid-West, to the British labourer, to the French or German peasant, - all of them groaning and travailing under conditions more or less intolerable, the slaves of the elements, the playthings of cyclones and blizzards, - to these poor weary workers, 


\section{Io Life and Sport on the Pacific Slope}

life beneath the soft blue skies of California was pictured as a sort of triumphant procession.

And so it proved - for a season or two.

I remember planting potatoes - the Early Rose variety - upon some land for which I had just paid (in '82) five dollars an acre. My neighbours, men of flocks and herds, laughed at my folly. They too had read the pamphlets, and sneered at the predictions of the prophets. According to them, land in Southern California was adapted to pastoral uses and nothing else. I was pronounced a tenderfoot with money to burn. The potatoes were planted in virgin soil. They increased and multiplied. In due time the crop was sacked and sold. After paying expenses, I found that I had cleared about one hundred dollars per acre!

I could cite a thousand such instances.

During the decade that followed, the Pacific Slope was peopled with petty farmers and fruit-growers. Land values steadily rose in obedience to the immutable laws of demand and supply. The men of flocks and herds, the "silurians" as they were called, the " moss-backs," ploughed up their pastures and sold their sheep and cattle. The spirit of the times had them by the throat. These patriarchs, knowing but one business (and that indifferently well), became of a sudden horticulturists, winemakers, fruit-growers, or dealers in real estate. They no longer laughed at others, they laughed with them. Everybody laughed. A broad grin rested on the face of the landscape. We were all blowing soap-bubbles, and that is glorious sport when you are young. And there was plenty of 
soap. It greased - so to speak - the ways of every enterprise. Heavens! what crazy crafts put to sea!

Town properties began to boom. At Los Angeles men stood patiently in line for many hours waiting to buy lots which they had never seen. The same lot was sold again and again within a week. New towns were hastily surveyed and put up at public auction. The bidders fought with each other for the privilege of securing corner lots on avenues that were laid out on - paper. These auctions were advertised in all the daily papers; excursions were organised; the railroads, of course, had more than a finger in the pie. When the new town-site was reached, meat and drink were provided for the hungry and excited buyers. A band furnished appropriate music.

Looking back it seems incredible that we could have been such fools. The craze affected all alike, rich and poor, young and old, wise and simple. If you had no money the banks clamoured for your patronage. Their gold lay in shining piles upon the counters. You could borrow what you pleased - at ten per cent. The men of business, the tradesmen, the lawyers, the doctors, and the parsoms bought land. We were all, in a sense, thieves, for we robbed Peter to pay Paul. The saloons did a roaring trade. Champagne, at a sovereign a bottle, was the only liquor fit to slake the thirst of the Native Sons. They smoked shilling cigars; fat perfectos, encircled with gaudy paper bands upon which was inscribed "Habana." Some of these full-flavoured weeds were made by Chinese cheap labour in the stews of San Francisco. Perhaps the opium in 


\section{2 Life and Sport on the Pacific Slope}

them lulled to sleep the prudence of the smokers. Who can tell?

During these halcyon days there were no Popocrats, no Silverites (for silver - as in the time of Solomon - was counted as dross), no Unemployed. Everything being upside down, the man became the master. I remember that I was graciously permitted to pay my cook eighty-four pounds a year for services worth, as we compute results in Europe, a ten-pound note. The ranch hands wore diamonds. On Sunday they arrayed themselves in suits of broadcloth at fifteen pounds the suit, silk-lined; they took their " best girls" for drives in well-appointed buggies drawn by fast pairs of trotters. As for the young ladies, I dare not describe their toilettes.

But the outward and visible sign of this amazing prosperity was most manifest in the houses (they were always spoken of as residences) which - like Aladdin's palace - seemed to be built and furnished in a single night. $\dot{A}$ propos of them I have a story: I was in a Pullman car, and we were passing through a valley dotted with most unsightly houses, - ramshackle buildings, for the most part, each an amalgam of half a dozen styles of architecture, each obviously built for show.

"What are yon?" said an old Scotchman, who was of the party.

"They 're private residences," replied an American, proudly. "Yes, sir, we're passing through Paradise Park. Six months ago, sir, this tract was a howling desert of cactus and sage brush."

"Eh, eh-h-h? Ye surprise me. Private residences, ye say?" 


\section{The Land of To-Morrow}

"Yes, sir. What do you take them for?"

The old Scotchman answered soberly: "I was of the opeenion that they must be lunatic asylums."

A big fellow, evidently a cattleman from Arizona, burst into Homeric laughter.

"Jee-roo-salem!" he exclaimed. "That's just exactly what they air."

Of course adversity trod hard upon the heels of her twin, prosperity. The pendulum began to swing the other way. We had had, as I have said, the measles, and the body politic was enfeebled and anæmic. Bad prices, an over-glutted market, drought, frost, and blight, set their stigmata upon us. "Laugh," says Mrs. Wilcox, "and the world laughs with you: weep — and you weep alone." Our laughter had rung through the East and Europe. Our youth and high spirits had enchanted the older civilisations. Now, recovering from a contagious disease, we were constrained to mourn alone, in silence and seclusion. The contrast between the smiles of the past and the tears of the present would have been pronounced humorous had it not been pathetic. When I first came to the West, I was speaking one day to a Califormian of London and the glories thereof. He listened politely, but when I had finished he said meaningly: "London is all right, though it ain't Paris, but both of them are - remote." To him, San Francisco was the centre of the solar system: the sun itself. Only last year I happened to meet the same man. His forehead, I noted, was puckered with perplexity; his clothes were shabby; his linen was not immaculate; he smoked a pipe. After a minute's 


\section{4 Life and Sport on the Pacific Slope}

talk, he said to me, feverishly: "Say, what ails California?"

I told him that, in my humble opinion, the hard times were over, that the future was rosy with the blush, not the flush, of returning health, and that California would be richer and stronger and wiser than she had ever been before. My friend's expressive face brightened.

"The State is all right," he replied earnestly. "The trouble lies with us. We 've had a bad dose of the swelled head. And now," he added mournfully, "we 've got cold feet."

In the slang that comes so pat to the lips of a Western man, he had said - everything.

When California begins to laugh again, the world will laugh with her. She is smiling already. The discovery of gold in the tributaries of the Yukon, the opening up of Alaska, the acquisition of the Philippine Islands, railroad competition, the Oriental trade, the possibilities that encompass the cutting of a canal across the Isthmus of Panama, ${ }^{1}$ and the completion of the Trans-Siberian Railway, the discoveries of coal fields and oil wells, these - to name only a few - are the heralds of a progress and prosperity that must prove radical and enduring. ${ }^{2}$

1 Since writing the above the Panama Canal has become the property of American capitalists.

2 The Hon. John Barrett, late United States Minister to Siam, writes: "Three great States, California, Oregon, and Washington, forging ahead in material strength with tremendous strides, developing vast resources, increasing rapidly in population, and possessing mighty potentialities yet to be exploited, debouch with their entire western boundaries upon the Pacific, and look to it for 
I am not prepared to discuss the pros and cons of Imperialism in a book which merely professes to be a pot-pourri of personal experience; but I can understand why the word itself is offensive to many good Americans. Expansion, to my mind, better expresses the purpose and policy of those who have annexed the Philippines. Already, we are told, the bill to be paid for these islands amounts to more than two hundred millions of dollars: a large sum, but not too heavy a price to pay for that moral expansion which has revitalised a country needing perhaps no fresh territory. Although I use the word "moral" I am confining myself to practical politics. The sentimentalists, the men of Utopia, are as usual astride the fence. We know only too well that from them proceed, in endless prolixity, empty words, - vox, et proeterea nihil. But even to those who take the world as it is, to those whose eyes are undimmed by party prejudice, the annexation of the Philippines and the protectorate of Cuba mean something far more important than the acquisition of rich territory, or the right to take a leading place in the councils of the nations. It is very questionable to the writer whether the one or other of these is worth much

a goodly share of their future prosperity. ... If we include the long winding coast of Alaska and the Aleutian Islands, we have a grand total of nearly thirty-five hundred miles facing the Pacific. ... China, Japan, Siberia, Siam, the Philippines, and Korea, not only want the flour of the Pacific Coast, but they are developing a growing demand for timber, manufactured food supplies, and a long list of lesser products."

Note. - The grand total of Pacific trade exchange - exports and imports - was $\$ 210,000,000$ for the year 1898. 


\section{6 Life and Sport on the Pacific Slope}

in hard cash to the United States; but it does seem absolutely certain - if the testimony of the past is to be accepted - that with nations as with individuals a policy of self-sufficiency, of restriction, and of isolation, is demoralising, and in the end disintegrating. The Spanish-American war, where millionaire and cowboy fought side by side in the ranks, did more to adjust the relations between rich and poor than all the synthetic philosophies of the world. Expansion will create new and enlarge old professions; it must have a permanent civil service, a diplomatic corps, an army, an adequate navy, a merchant marine; but these are merely the phylacteries of evolution; beneath and unseen lie the quickening pulses of a life richer in its opportunities, wider in its scope, more varied and variegated, a life in sympathy and in touch with others, a life that is ampler, nobler, freer, and happier than the life which lives in and for itself alone. As the egg of an eagle is to the monarch of the air, so is the incubation to the "hatch and the disclose" of a great nation.

However, dismissing the subject of Imperialism as one not germane to these pages, we must remember that rightly or wrongly the Philippines and Hawaii now belong to the United States, and that their possession affects the future of the Pacific Slope more than any other part of Uncle Sam's domain. Californians, at any rate, have no cause to complain of or criticise a policy which must benefit directly and indirectly every farmer and merchant west of the Rocky Mountains. It has been computed that the Philippines' imports from 
foreign countries (including Spain), compared with the imports from the United States, were in the ratio of thirty-three to one. This fact indicates the volume of trade awaiting a market nearer (China excepted) by thousands of miles than any I have named. Roughly speaking the imports into the Philippines are some ten millions, while the exports will be about twice as much. But this is nothing. Mr. John Foreman, in his book entitled "The Philippines" (London, 1899), says that the possibilities of development are so great that the next generation will look back with astonishment at the statistics of to-day. If Mr. Foreman proves a prophet, San Francisco will be one of the five great cities of the world. She has a harbour that can be entered by any ship afloat, at any time of the tide, and at all seasons of the year; a harbour vastly superior to New York harbour; a harbour with an anchorage of seventy-nine square miles! New York has an anchorage of nine and a half miles.

- Let us make, however, no mistake. The West, intellectually and morally, has proven itself both wild and woolly. The healthiest sign of a vigorous recovery is the recognition of this by the people themselves. Cold feet may be quickly warmed; a swelled head is not so easily treated. For the present the Pacific Slope is - so to speak - in the corner. Our nurses, the great capitalists, have their eyes upon us, but we must be careful. It is time for us to put aside childish things, the swaddling-clothes of conceit and ignorance, and to assume instead the toga of manly modesty. 


\section{8 Life and Sport on the Pacific Slope}

Then, and not till then, we can take our rightful place in the senate-house of the world.

When I was asked to write this book, I replied that although I was provided with matter for it, the varied experiences of seventeen years, yet the manner of setting them forth adequately would prove, I feared, beyond my powers. I have reason to know that the people of the West are extremely sensitive to criticism - especially from Englishmen. And having many warm friends in the West, having, moreover, many connections by marriage amongst them, wishing, if I did write at all, to write with entire frankness, I hesitated for a long time before I undertook a task that may be best described by the old Greek word of - " bitter-sweet." In the Greek it is "sweet-bitter," for the ancients held that the bitter follows the sweet-and remains. We, as Christians, hold otherwise. With us the sweet prevails and endures. Speaking personally - and it is only as an individual who has lived many years of his life in the West that I am entitled to a hearing - I would say emphatically that the bitter has passed from me. Were it not so I would hold my tongue. More, had I not suffered in common with the people of the West, did I not know, as they know, the peculiar trials and temptations of a new country, if I was not willing to share the blame, to shoulder my part of the load, I would lay down my pen before it is hardly wet. My object is primarily to show what life in the West is, not what it ought to be. I believe in the Pacific Slope. I am profoundly con- 


\section{The Land of To-Morrow}

vinced that it has a great and glorious future before it; and that it stands to-day upon the threshold of that future. If Horace Greeley were alive, I am sure that he would repeat his famous dictum: Young man - go West. 



\section{II}

\section{THE MEN OF THE WEST}





\section{II}

\section{THE MEN OF THE WEST}

M UCH was forgiven to Mary Magdalene, quia II multum amavit, and much may be forgiven to the sowers of the West because they have laboured so hard and so faithfully. - Nice customs curtsey to great kings, they grovel before conquerors. And the men who apprehended the possibilities of the West, who not only crossed the plains, and the forests, and the mountains, but who recrossed them with shining ribands of steel, were - Cæsars, endowed with the strength and the weakness of giants. You must consider them and their actions, in the aggregate, panoramically, as you would survey a Californian landscape.

The English traveller, who merely touches the phylacteries of American life, always lays stress upon the dollar as being the unit of value on the Pacific Slope. According to this authority we are money-grabbers, worshippers of the Golden Calf, sacrificing to the god our own flesh and blood. And yet no people on earth are more truly lavish with their gold than the men of the West; no people care less for gold as gold; no people greet the loss of it with greater fortitude and good-temper. What gold represents - power and success - is dear to the Native Son, for he knows that he cannot plead as an excuse for failure the burdens of 


\section{Life and Sport on the Pacific Slope}

tradition and convention that hamper the strivers in older countries. In the West runners are nude when they start: the race is to the swift, the battle to the strong. Each is given credit for what he does, not for what he is. Indeed, in a country where the only gentlemen of leisure are tramps, it is shameful to be other than a bread-winner. Dives works harder than Lazarus. Only the other day a millionaire, a comparatively young man, was stricken down. He died of - over-work. Why did he not take it easy? Surely, he had enough. I knew this man, and he told me that he laboured more diligently than the meanest clerk in his employ, and for practically the same wage: clothes, board, and lodging. He dared not do less than he did. It is against the spirit of the West to shirk responsibilities.

Mr. Clarence Urmy, a Californian, whose tuneful verses are familiar to readers of American magazines, has written some charming lines upon this theme. According to Mr. Urmy, those only fail who strive not. The sentiment is as pretty as the verses that embalm it. And it is a sentiment essentially of the West. But it would be truer to say that only those who strive can know the bitterness of failure. In a new country the strife is so strenuous, it demands so many sacrifices, that failure becomes almost a synonym for death. God help the man who, in the accounting that comes to all of us sooner or later, finds his balance on the wrong side of the ledger. Surely, in that dark hour the sense of what he has suffered and endured becomes a crown of thorns. Later, perhaps, he 
may realise that it is better to have striven in vain than not to have striven at all.

The men of the West never take the word "failure" home to their wives. It is locked up, when they leave their office, in that symbol of prosperity, the safe, which often contains nothing more valuable than the record of wasted endeavour. One and all are stoutly self-assured that if the slippery yesterdays have eluded them, if the silvery to-days belong to others, the golden to-morrows are theirs by the unalienable rights of faith and hope. The door-mat kind of man who lies down grovelling, and permits the foot-passengers to wipe their shoes upon him, is not to be found west of the Rocky Mountains. Robustly conscious of his strength, the Native Son confronts the beasts of the marketplace with the same courage and determination that sustained his father in the wilderness. I have stood in the wheat-pit of San Francisco when wheat was jumping like a kangaroo. Around me were men - some of them young - who had large fortunes at stake. I saw one "bear" unmercifully gored by the stampeding "bulls." But he picked himself up with a grin, lit a cigar, ate a capital luncheon, told a good story, and made it plain to my wondering eyes that physically, mentally, and morally, he was none the worse for his misadventure.

Curiously enough, despite this pluck and energy, the men of business are ignorant of much that they ought, in their own interest, to know thoroughly. The average English gentleman, the magistrate and landlord, lacks the intelligence, the cleverness and 


\section{Life and Sport on the Pacific Slope}

tact of his American cousin, but, narrow and prejudiced as the Briton is in many ways, he takes the broader view in regard to the conduct of the world's affairs. Not till the war with Spain did these challenge the serious interest of Americans. I have read, even in sober reviews, the grossest blunders, the most absurd misrepresentation of facts within the reach of any journalist who has access to a library. In this particular regard the press is French: to please the public, to tickle the ears of the groundlings, they ignore the truth as perversely as the Dreyfusards and anti-Dreyfusards writing in the "Figaro" and the "Echo de Paris." In an English party paper, say the "Standard," you will mark that an account of a Liberal meeting will be faithfully recorded. The speeches will be printed verbatim; the cheers, the hisses, the questions, will be honestly reported. I have never read in a Western paper a true description of a political meeting. The facts are embellished or mutilated according to the political views of the editor. Of an enemy, who in private life may be a blameless citizen, nothing too shameful can be said. He is proclaimed a Judas, a Catiline, a Nero, a Verres. Ancient history is ransacked to find his peers in infamy. This is entirely a Gallic characteristic, alien to the AngloSaxon spirit and love of fair play. The men who wish to be "posted" buy two daily papers, the Republican and Democratic organs, and form their opinions by what is left unsaid in both.

On the other hand, the Western man is keenly conscious of his limitations. He wants to know. England is full of men who are quite convinced 


\section{The Men of the West}

that what they don't know is not worth knowing. I can hear the voice of the old colonel, a rasping voice mellowed somewhat by sherry, as he pronounces all subjects without the magic circle of his own intelligence-bosh. Not so the Western man. He is catholic in his sympathies. Everything interests him - and everybody. He devours an essay upon liquid air and its possibilities, and turns from that with gusto to a vol au vent of political gossip, or a chaudfroid of economics. And this being so, it is a thousand pities that the cooks who cater to this appetite should not supply wholesomer diet. Western people suffer from dyspepsia, but what they eat is as Mellin's food compared to what they read.

Some months ago I was returning from a fishing tour in British Columbia. In the smoking-room of the Pullman car, I encountered a youth of about seventeen, who, taking me for a tenderfoot, proceeded to set forth at great length the resources of California, its sociology, topography, and climate. I listened patiently for a couple of hours. Presently he asked me if this were my first visit to his State. I replied in the negative, saying that I lived in California, that I owned land, that I was engaged in a large business. He looked uncomfortable ; then in quite a different tone he said: "Say - when did you first come to California?"

It was my turn.

"You are a Native Son?"

"I am," he answered proudly and promptly.

"About seventeen years old?"

"That's right; seventeen last fall." 


\section{Life and Sport on the Pacific Slope}

"Ah-well, I came to the State of California about the same time you did."

He blushed scarlet; then he laughed heartily. "Great Scott! Why did n't you tell me to come off my perch?"

After that, he asked a number of questions and listened civilly to my replies. We parted the best of friends.

An Englishman is never seen to worse advantage than when he is insisting upon what he is pleased to call his - rights. For in the development of character it is expedient that men should sometimes do without privileges to which they conceive themselves entitled. Perhaps if we clamour too persistently for our dues in this world, we may also, in the world to come, be dealt with according to our deserts. At any rate it is a charming characteristic of the men of the West that they are good-humouredly content with less than that to which they are legally and morally entitled. As much, be it noted, cannot be said of the women. In San Francisco, at certain times of the day, the demand for seats in the cable cars invariably exceeds the supply. And the men of course always give up their seats to the ladies, who accept them without thanks. Once, however, I saw a Briton who refused to budge. Finding the eyes of the fair upon him, he fidgeted and finally burst into speech. "You 're all looking at me," he said angrily ; " and you think I ought to give up my seat. Well, I'm not going to do it. And if the men of this country had more sense they'd keep what they 've paid for, 
and then the cable companies would provide seats enough to go round." He was scarlet in the face before he finished, and everybody laughed.

At the theatre, in church, at race meetings, country fairs, at all times and in all places where a little patience and good-humour temper what is disagreeable, the people of the Pacific are at their best.

Once at a performance of "La Tosca," some youths in the seats behind me were "guying" the actress who was sustaining the principal rôle. And this to the annoyance of all of us. A man not far from me silenced them. "That lady on the stage," he said, very politely, "is making so much noise that we cannot hear what you are saying. But I hope we shall have the pleasure of listening to your criticisms later, after the act is over."

At times something more drastic is wanted. A lady had been rudely treated by some minor official of a railroad. As a rule, ticket-sellers give themselves great airs. To women, however, they almost invariably show courtesy and consideration. This man was an exception. The lady, very indignant, at a loss for words, but with a comical sense of humour, turned to a stranger at her elbow. "Pray, sir," said she, "tell this man what I think of him." The stranger proved equal to the task set him. In a melancholy drawl, without betraying the smallest excitement, he said slowly: "Sir, this lady thinks you are an understrapper, clothed with a little brief authority, whose only qualification to the position you occupy is your - impudence."

The English reader will pronounce this to be tall 


\section{Life and Sport on the Pacific Slope}

talk. In England, even amongst men of mark, niceties of speech are banned and barred. The phrase-maker is commonly a prig, the precisian in grammar is despised as a pedant. The American on the contrary, has found out that a well-sharpened tongue is more reliable than a six-shooter. But it must be noted that (regarding the tongue as a weapon) conversation in America is necessarily aggressive and competitive. Club talk in England is narcotic in quality, in the West it is stimulant. I have met vampire talkers, who seemed to suck from the brains of others vigour and vitality. Some impress one painfully as struggling against odds too great to be overcome. Up to the neck in a quagmire of words, they finally sink into silence, defeated but not disgraced.

I remember meeting a friend who had been elected a state senator, and asking him how he had fared at Sacramento. "First rate," he replied, taking hold of the lapel of my coat. "Yes, first rate. I was really scared out of my wits, but I didn't wilt. And I rehearsed carefully my own little song and dance. You read my maiden speech? Yes: good-eh? My boy, I practised it in front of my mirror. Yes, I did! And I gave 'em a little of everything: a dash of Mill, a teaspoonful of Spencer, Shakespeare, the Bible, and a line from the Mikado. It was great, great! It hit 'em all. I tell you - don't give me away that the western orator's vade mecum, his staff, his shield, his cruse of oil, is - a Dictionary of Quotations."

Nothing upsets the equanimity of a Californian 
crowd. At one of the great football games between Stanford and Berkeley Universities, a huge stand, flimsily constructed of timber, began to shake ominously. Several persons jumped up and a panic was imminent. Just then there arose a wellknown man, something of an autocrat in his way. "Sit down!" he said sternly. "SIT Down! SIT DOWN!" He was obeyed, but a clear voice was heard in reply: "That's all right, Fred. But why don't you sit down yourself ?"

Another anecdote that illustrates well the temper of an American crowd as contrasted with an English assembly is worth repeating: A great singer was enchanting a large audience, when suddenly at her feet a column of flame soared up into the flies. In the front row of the stalls a man sat beside his wife (some wags said she was his motherin-law). As the flames shot upward this fellow bolted. He was next to the gangway, and was up and out of the theatre before the audience had realised what was impending. The flames vanished; the cantatrice smiled and assured the house that the danger was over. Then the man came back! In England he would have been greeted with hisses. In America he was cheered! For my part, I think that his moral courage in returning was more amazing than his cowardice in running away.

In a thousand ways the men of the West show that they are willing and content to accept less than their due. In lawsuits a compromise is generally possible, whereas in England the same suit would be fought to a finish. And in their 


\section{Life and Sport on the Pacific Slope}

daily dealings with others, the Native Sons are humorously sensible that "the other fellow" may get the best of the bargain, and if he does none complains. A question at such a time would provoke a grin and the assurance that the speaker's turn would come - later. I remember a very stout dealer in real estate who once showed me a rocky and sterile piece of land, for which he asked an exorbitant price. I was indignant. "You must," said I, "take me for a fool of fools. How dare you show me such a scarecrow of a ranch as this! To whom does it belong?"

My stout friend answered sorrowfully: "It's mine. I was fool enough to buy it in boom times; I've been waiting ever since to find a bigger fool than I to take it off my hands. And," he added sotto-voce, "I don't know now that I 'll ever find him."

Another real estate agent was showing some rough hills to a client. The day was hot, the slopes were almost perpendicular, and the client tired and out of temper. After seeing the ranch he demanded the price. It was named. "What! You have the nerve to name a figure as steep as that for such land!"

"Well," murmured the other, blandly, "you see the land is steep too."

The consideration shown to employees by the great corporations and business houses is a manifestation of that genial, kindly spirit which is indeed as mortar binding one human soul to another. The master seldom forgets that once he was the man, and the man never forgets that he in his turn may be the master. I cannot recall, during seventeen 
years, one single instance of a cruel and cutting rebuke from one in authority to a clerk or servant. A friend of mine had a clerk who was always forgetting important duties: letters would be left unmailed; important entries on the books would be ormitted; messages, even, were sometimes not delivered. Said my friend to me one morning: "Really, I must speak to John." So John was summoned, and I wondered what manner of rebuke would fall upon his head. "John," said my friend, "it is most astonishing what a very bad memory you have. But I believe that in time it will improve, because I notice that you have never once forgotten to draw your salary on the first of the month." John took the hint, and after that my friend was truly and faithfully served.

It has been said that corporations have no consciences. I can personally testify that this is, generally speaking, untrue of the banks in the West. The kindness and forbearance shown by them to their debtors have tided many and many across the quicksands of ruin. It is often, I admit, the policy of the strong not to seize the spoil, but I know of cases where bankers have preferred the interests of customers to their own, and during recent years of drought and panic, notably during the time when the Australian banks were breaking by the score, the policy pursued by the capitalists of California averted a general panic. Had they, in their hour of sore need, pressed claims upon an impoverished community, half the farmers and storekeepers in Southern California would have become bankrupt. More than one bank suspended 


\section{Life and Sport on the Pacific Slope}

payment, but the confidence of the people in those who held their fortunes in the palm of the hand was sustained and justified.

I was in California when war was declared between the United States and Spain. Of that war so much has been written by so many and such able men that little remains to be said-now. Later, when the history of it is set forth calmly and dispassionately, when time has adjusted the scales by which the great events of the world are measured, it will be found that the Declaration of Independence has not been fraught with more vital interest and significance to the people of the New World than this declaration - so to speak of Dependence: the dependence, not of the weak upon the strong, but of the strong in relation to the ignorance and folly and vice of the weak: a confession that no nation, however great, can stand alone. The particular causes that constrained Mr. McKinley to let loose the dogs of war have not yet been determined. The ugly word "revenge" was in many mouths. Political expediency, increase of territory, were phrases heard at the street corners and in the clubs. And, doubtless, these and half a dozen others were factors in'a sum that must have sorely puzzled the President and his Cabinet. But, personally, I believe that from Maine to California the Puritan spirit, using the adjective in its best sense, was stirring the hearts of the people.

There is a feeling all over America, but more especially in the West, a feeling essentially Gallic, that leads men to pose as being worse than they 
are. I remember a charming American woman saying to me, a propos of her husband: "He is the most domestic man I know, but he would like to be thought a little wild." Now, the London "Spectator" predicted war some weeks before it was declared, and it pointed out the good motives that would surely animate our cousins over-seas. The article was able, but a note of condescension lurked between the lines of it, that condescension in regard to foreigners of which James Lowell wrote so delightfully. American readers might infer from the "Spectator" that they were expected by England to do their duty, not as free-born Americans, but as the kinsmen of Englishmen. I do not say that the writer of the article in question deliberately meant this. But I assert that by Americans such interpretation was placed upon it, and upon other similar articles in the London papers. At any rate, the San Francisco "Argonaut," the best weekly upon the Pacific Slope, and one of the best in the world, burst into coloured sparks of rhetoric. After reading carefully an impassioned leader, I was quite satisfied (temporarily) that Duty, as an entity in American affairs, was dead, that Evil always triumphed over Good, that Might was Right, and that the finger of Destiny was the finger of Death. The article was widely read in the West, and its phrases snapped up by many an Autolycus. Men who had talked glibly enough only the week before of philanthropy, and the obligations of a model republic, went about the streets dancing a sort of Carmagnole. It was high time - some of them said - to grab all they could get. 


\section{$3^{6}$ Life and Sport on the Pacific Slope}

Why not be bold and bad, like the buccaneering Briton? Let the United States annex Cuba, and Spain, and Europe, and the Aurora Borealis, if necessary. The reaction had set in. Then I remembered one of Max O'Rell's best stories. Mons. Edmond About had written of a hero that he was "virtuous as a pupil of the Polytechnique." The pupils of the Polytechnique at once held an indignation meeting that simmered into the form of a round robin to the distinguished author. "Monsieur," it ran, "pray mind your own business. We are no more virtuous than you are!" Max O'Rell always added that he knew this story was true, because he signed the round robin himself !

But be the causes of the war what they please, the spirit in which the youth of America responded to the call of arms must awaken the liveliest admiration in all of us. If Mr. McKinley had asked for a million men, he would have had them within twenty-four hours. Friends of mine, men with many interests at stake, volunteered to serve in the ranks. A private's musket might have been a marshal's batton, judging by the eagerness with which it was sought. One patriot - to cite a single instance out of a thousand - no longer young, very rich, occupying a high position in society, a man of fashion and culture, wired to Washington entreating his friends there to procure him any position, however humble, in either the army or navy. It is said that his wife wired also : "Pay no attention to Jimmy." No attention was paid to Jimmy, except perhaps by the Recording 
Angel; but his fervent wish to serve his country, abandoning thereby all that most of us count as making life worth living, has curious significance to a foreigner. There are about a million Jimmies in the United States.

In the West the war was taken very soberly. In the clubs, in the restaurants and cafés, at the theatres and music halls, there was none of that cheap and vicious excitement that in its worst phases is delirium. The regiments marched into San Francisco, they sailed through the Golden Gates, and always the streets and docks were black with friends to wish them "God speed you." An observer could not fail to be profoundly impressed by these comings and goings. Between them and the mimic parades of the National Guards upon high days and holidays, was the difference between the real thing and the sham. The faces of the fathers were grim as they watched their sons file past (they were thinking of Gettysburg and Vicksburg), and the women's cheeks were wet.

The word "Chauvinism" has been used more than once of late in connection with the people of the West, - a word to which a deserved stigma is attached. But, for my part, the militarism of the people was a pleasant thing to witness. Rich and poor alike joined hands in singing the national anthem, and the fact that it is set to the music of "God Save the Queen" did not detract from its power and purport so far as I was concerned. Columbia called her sons to arms, -

"And all the bugle breezes blew Réveillé to the breaking morn.". 


\section{$3^{8}$ Life and Sport on the Pacific Slope}

The Stars and Stripes floated from the top of every house. Upon hundreds of thousands of windows were pasted paper flags. The girls encircled their hats and waists with ribbons of red, white, and blue. The boys bought badges and buttons. The men wore tiny enamelled scarf-pins. Some Englishmen took exception to this perfervid patriotism. They said that love of country was cheapened when a man wore it in his cravat instead of in his heart. In England, continued these critics, the flag was held too sacred to be defamed to calico uses. ${ }^{1}$ I can quite sympathise with this point of view, but I can also sympathise with and apprehend the spirit of a new country which exacts, and exults in, a demonstration. And a demonstration is necessary, - the confession of faith of a heterogeneous people. Englishmen can well take the patriotism of their fellow-countrymen for granted; they are and have been Englishmen for nearly a thousand years. But in the West is it not common prudence to demand from the Kelt, the Teuton, the Latin, the Slav, an answer to the question, "Are you truly of us, or merely with us?" Fifty years hence the Stars and Stripes will be still the beloved flag, but it will not be seen twisted around the hats of the maidens, or pasted in paper upon the windows.

The men of the West may be divided into three classes: those who live by the seaboard, those who live on the plains, and the stockmen and miners who dwell in the mountains.

1 Since these lines were written the author has witnessed the scenes in London after Ladysmith and Mafeking were relieved. 
It has been my unhappy experience that most of those who live by the seaboard are - tricky, as were, doubtless, the traders of Tyre and Sidon. And there is small excuse for their trickiness inasmuch as to them, the citizens of a great republic, have been given advantages denied to the strivers in less favoured countries. All these knaves know the right, yet they choose the wrong. In the old world you find the seller putting the biggest strawberries on the top of the pottle, his smallest potatoes in the bottom of the sack, water into the milk, sand into the sugar, and so forth. In the West, where neither poverty, nor vice, nor disease, nor ignorance can be pleaded in excuse, these tricks assume a darker complexion.

It is true that the worst offenders come from the East and from Europe, for the West is a sanctuary to the pariahs of the nations. Here, mind-healers, clairvoyants, astrologers, card-sharpers and the like, flourish as the bay tree. These are the dregs of the older civilisations, the scum of the new, and therefore the more readily seen. Perhaps, if choice must be made of two evils, it is better that sewage should be spread upon the fields than lie festering in cellars. The bad that has come to and is in the West lies upon the surface of all things, in full view of a too hypercritical world. If this scum be not soon skimmed and cast to the void it will filter through every stratum of society, as it has done elsewhere, and then the last state of the West, outwardly immaculate, will prove worse than the first. I believe, personally, that the period of purification has begun. There is said to be honour amongst thieves. 


\section{Life and Sport on the Pacific Slope}

Western thieves are exceptions to this rule. I remember subscribing toward the construction of a steam schooner that was to carry at a minimum rate the produce of our county to San Francisco. Many farmers pledged themselves to ship their wheat and wool by this vessel. The railroad, a local road, was run upon the well-known principle of charging the shipper "all that the tariff would bear," a policy which enriched the shareholders of the road, but did not endear them to the farmers of our county. It was pointed out that as soon as the steamer was put in commission, the railroad rates would be cut in a competition that must prove disastrous to the fortunes of the steamer, unless the farmers loyally observed their contract. It was also pointed out that if the farmers failed to support the steamer, it would be sold, and that the railroad would have our county at its mercy. Were they loyal? Had they the wit to avail themselves of an opportunity? No. The railroad did cut their rates. The poor little steamer was wiped from the seas. And then, when it was too late, the penny-wise farmers paid in full for their folly and dishonesty.

Of the men who live in the plain, the less said the better. The sun seems to have sucked the sap from them, leaving them, as it leaves the grass in the pastures, drab-coloured and withered. Here are the wheat farmers of the Pacific Slope, who hold the prosperity of the inland towns at the mercy of the elements. If the sun shines too fiercely, if the wind blows too hard, if the rain fails, if blight, or rust, or wire worms attack the crops, the community trembles. The banker, the storekeeper, the 


\section{The Men of the West}

lawyer, the doctor, and the parson may well join in the farmer's prayers for rain. To all, a drought spells ruin. These big gamblers are the curse of a new country. They have done enormous harm to the State of California. They impoverished the soil that yielded at first fabulous harvests, and they impoverished the souls of those dependent upon their success and failure. Credit is the life blood of a new country; it irrigates the waste places of the earth. Without it the greater portion of the West would be to-day what it was in the time of Daniel Webster - a wilderness. But credit, like water, can do grievous harm. Credit, in full flood, has swept from the West those habits of thrift and industry and patience that alone make for character and prosperity in a community, as in an individual. They will return, they are now returning, halting in the wake of adversity, and under more generous conditions will become vertebrate and vigorous.

In the old days, it will be remembered, Lot chose the plain, and to Abraham was given the hill. And since those ancient times, it has always seemed to me that the best men live nearest the stars. Certainly in the West you will find that the mountaineers are a finer race, more robust than their brethren of the plain, simpler in their habits, breathing a purer air and leading a purer life. For the most part they are miners or cattlemen. If you meet one of these fellows, be sure and mark the quality of his glance. George Eliot's much criticised adjective " dynamic " describes it best, - that all-compelling gaze, the glance of a man whose eyes are weapons not of offence, but of defence. In the foot- 


\section{Life and Sport on the Pacific Slope}

hills, in the forests, and in the plateaux of the Sierras, you will find these men. They are a silent race, save when possessed of strong drink, sober of countenance, impassive (some of them) as Redskins, very prejudiced, but as a rule honourable, kindhearted and truthful. Like the ancient Persians, they can ride, shoot, and speak truth. They are loyal to their friends. Some years ago two outlaws set the officers of justice at defiance. They lived on the plain, but in their hour of need betook themselves to their friends in the mountains. Here they found sanctuary and food and drink. A great price was set on their heads, but for many months they remained at large.

Shooting and fishing among these people, I have always found them hospitable and honest. Often they have refused money for my board and lodging. Not once can I recall an overcharge for services rendered. Talking with them around the campfire, I have been told amazing stories of obstacles surmounted, stories of almost superhuman pluck and endurance. Of the life beyond their forests and mountains they are profoundly ignorant. An English Minister of Education, Sir John Gorst, has said that he considers " reading, writing, and arithmetic to be of dubious value to a boy who lives in the country; and grammar a positive curse." The men who live nearest the stars are learned in other lore, the ancient wisdom of the woods and streams, where every leaf and pebble tells its tale to the attentive eye and ear. They are still masters of the arts that an educated world has forgotten. Perhaps contrast colours too vividly the imagination, and 


\section{The Men of the West}

warps our sense of proportion. But, in the cool northern woods in springtime, when the forest appeals in turn to all the senses, lying, may be, on the banks of a lovely stream, watching the rainbow trout, the big fellows at ease in the tail of a rapid, seeing, perhaps, a stag quenching his thirst, hearing the melodious murmur of the stream, the soft sigh of the cedars kissing overhead, smelling the perfume of the pines, I have wondered if this, the life of the primal man, is not, after all, the best that can be lived under God's high heaven. At any rate, as an antidote to the fever of modern life it has no peer. O weary worker of the West, see to it that for a season in each year you live out-of-doors! Sleep beneath the stars. Eat the food that the woods and streams provide. Fill your lungs with ozone and oxygen, fill your body with plain, wholesome food, fill your heart with the freshness and fragrance of the forest, your soul with the glory of the firmament; and then, when you return to the roaring thoroughfares of the world, you will realise that, no matter how dun the days of strife may be, you too have had your golden hours - of rest.

I have spoken hitherto of men generally, but the West produces certain giants, who by virtue of their size challenge special attention. These are the aristocrats, the few, who at all times and in all places mould and control the many. I shall name two. Mr. Collis Huntington was the President of the Southern Pacific Company, the richest man in California, the ablest financier in the United States, and one of the shrewdest politicians of this or any 


\section{Life and Sport on the Pacific Slope}

other age. He has been compared to Bismarck, to Napoleon, to Gladstone. He had enormous executive ability, stupendous capacity for work, a great sane mind in a great sane body. I have had the pleasure of chatting with him, and I recall without effort his leonine head, his keen, kindly eyes, his massive body, and the power and vigour that emanated from it. Mr. Huntington could stand upon the ragged edge of an abyss, and gaze undaunted into frightful depths. There is said to be a line between right and wrong. Mr. Huntington ploughed close to the line, where the soil is richest; some say that he went beyond it. That line, most of us will admit, is a meridian, variable and varying. Perhaps when Mr. Huntington's figures are given to the public, it will be agreed that his line has been, after all, nicely computed. To most of us this same, line is a broad strip of debatable land upon which we wander, poor vagabonds, asking of each other where we are. Tò Mr. Huntington must at least be given the credit of always knowing exactly where he was. More, he showed others where and what they were. He plucked the eagle's feathers from many a daw; he stripped many an ass of his lion's skin. An octogenarian, he worked as hard as any youth. Born in a small Eastern village, he was essentially of the West. His life was simple, primal even. By the sweat of brow and brain he made himself - a Colossus. And you cannot measure him with the foot-rule of pygmies.

Of Mr. Huntington scores of stories are told. One, pregnant with significance, is repeated from Shasta to San Diego. The driver of a cab, recog- 
nising the great man, protested that he had been paid no more than his legal fare. "Your nephew," said the fellow, "pays me three times as much."

"Is that so?" replied Mr. Huntington. "Well, you see, my friend, I have not a rich uncle - as he has."

What Mr. Huntington has been to the material growth of the Pacific Slope, Doctor Jordan, of the Leland Stanford Junior University, has been to the more subtle development of the world unseen. His influence to-day amongst the young men of the West cannot be measured till to-morrow. In a country where gold colours the very flowers of the field, Doctor Jordan; like Agassiz, has had no time to make money. He has refused preferment again and again, cut down his salary, when the university was in financial straits, laboured strenuously in many fields without the labourer's wage, and, in fine, has set an example of energy and fortitude that thousands are striving to emulate. But David Starr Jordan's friends - and their name is legion - say that he does too much. $\mathrm{He}$ is a world-famous ichthyologist, an international authority upon natural science, a writer of note, a poet, a lecturer, a journalist: the Charles Kingsley of the New World. Is it not to be feared that this Protean capacity of playing a dozen parts will work evil rather than good? The weakness and the strength of the West lurk in its varied resources. A child taken to a toy-shop squanders his dollar upon a dozen trifles because the sense of selection is paralysed. Likewise the young man, apprehending, through the clear lenses of a Jordan, the infi- 


\section{Life and Sport on the Pacific Slope}

nite possibilities of the future, the alluring wares that Nature has spread upon a thousand counters, may wander here and there, frittering away his capital of energy upon a score of gewgaws, whereas he might have bought and paid for a radiant pearl.

Some of my readers must have seen that amazing Italian, Fregoli. He plays by himself a comedietta, in which he alone assumes the various rôles. He is ubiquitous. Here, a dotard - there, a ballerina. There are many Fregolis in the West. I used to know one who was in turn doctor, parson, undertaker, justice of the peace, paper-hanger, and painter. He played all these parts indifferently well; he was intelligent, temperate, hard-working - and he never had been able to earn more than a bare living. 


\section{III}

\section{THE WOMEN OF THE WEST}





\section{III}

\section{THE WOMEN OF THE WEST}

T REMEMBER a pretty Californienne with whom 1 I used to dance, a true daughter of the West, charming on account of her beauty, vivacity, health, and youth. She had never left the Pacific Slope except on the wings of a perfervid imagination and she afforded an amazing contrast to other young women of my acquaintance, the gilded girlies who had had what is humorously called advantages, - a season in London, a winter in Riviera, a summer at Newport, and so forth. Perhaps I had better say at once that in speaking of the men and women and children of the Pacific Slope, I do not include the Anglo-Franco-Americans, who have built around themselves a stone wall that I, being an Englishman, am willing to respect.

Our pretty Californienne dines in the middle of the day and sups at six. The same girl, in England, would be painfully ill at ease in the presence of a stranger. Moreover, you would note regretfully that the English girl's skirt was ill hung, that her hair was somewhat tousled, that her shoes were vilely cut. The Californienne, on the contrary, challenges criticism out of a pair of sparkling eyes. "Take a square look at me," she seems to say; "it will brace you up." Should you accept this invitation in sober earnest, defiance will curve her lips 


\section{$5^{\circ}$ Life and Sport on the Pacific Slope}

into a smile. The odds are she will put you to the blush with the sharp question, "Anything wrong?"

The first time that I had the honour of a valse with this young lady, I committed a breach of etiquette. She danced admirably. I-well, no man is bound to incriminate himself - I did my best. But, after circling twice round the room (the night was sultry), I stopped and began to talk. She seemed provoked at something, answered in monosyllables, and when I said, "Shall we go on dancing ?" replied curtly, "That's what we 're here for." After a couple of turns I stopped again, and then my lady Disdain, out of the fulness of her heart, spoke :-

"It's not hard to tell that you 're an Englishman." "Thank you," said I. "My dancing betrays me."

"Yes, it does. No, no, I don't mean that. You dance fairly well, but - "

For a couple of minutes she would not budge from her "but." Finally, she was constrained to entire frankness. Why had I stopped twice without consulting her convenience? I was so paralysed with amazement that I had no answer pat, save the obvious one. I had stopped - so I said - because, in my opinion, it was better to stop than to fall down.

"Giddy?" she demanded incredulously.

"Yes; giddy."

"American men never get giddy," she observed, after a significant pause.

"If they did," I submitted, "would they stop without consulting their partner?"

"They would go till they dropped," she retorted. 


\section{The Women of the West}

Did she mean it literally? Perhaps not. But truth underlies these idle words. The Western man is expected to "go till he drops;" and the Western woman sets the pace. Are women judges of pace?

You may roughly divide the daughters of the West into two great classes: the bond and the free; those who have leisure and those who have none. The woman of leisure is a charming creature; clever, plastic, cheery, and always womanly (the English girl who hunts, shoots, swears, and gambles has no understudies on the Pacific Slope); but, be she maid, wife, or widow, she obeys no law save that of her own sweet will. There are many exceptions, of course, but the Western woman of leisure, in startling contrast to other women, does what she likes rather than what she ought; although often duty and inclination march hand in hand? If a daughter of the West sits up with the sick child of a neighbour, the chorus says, "How good of her!" The chorus does not say, "How good for her."

She is unconsciously the most selfish creature of her sex. To find her mate, you must go to England and take the gilded youth who fondly thinks that the world owes him a living. He has had, as a rule, an expensive and superficial education, he can talk glibly enough about most things on this earth, particularly his neighbours, and his neighbour's wife. He has a feminine love of being "done well." He will join a great house-party and leave it without saying good-bye or thank-you to his hostess. He will invite his pals to drink his father's vintage 


\section{Life and Sport on the Pacific Slope}

champagnes and to shoot his father's coverts; and when the author of his being writes a fatherly letter complaining that his son's extravagance will force him (the sire) to let his town house and spend the season out of town, the son sends a postcard in reply, expressing his regret and offering to rent the house in question himself! Once and again a youth such as I have described (from life) marries a daughter of the Golden West; and then Greek meets Greek. One girl I knew married a man who died under peculiarly tragic circumstances. Everybody condoled with her, and perhaps she grew tired of cheap verbiage. At any rate she silenced sympathy one day by saying, in the most naïve manner: "Yes, it was dreadful, dreadful; but, thinking it all over, I would sooner it was him than me!"

It is not uncommon to read in the society notes of a San Francisco paper that Miss X- is entertaining a party of her friends at her country place. The country place belongs to her father the breadwinner, but he is seldom seen and as seldom heard. The English father of daughters, loud-voiced, didactic, prone to fits of "waxiness," the laughing-stock of many, and the terror of the few unhappy women over whom he rules, is unknown on the Pacific Slope. If a Californian father ventured to find fault with a daughter, he would be sent, metaphorically speaking, to bed. For a week he would be given to understand that he was in disgrace. $\mathrm{He}$ would have to take his meals - as it were - at the sidetable.

The women I am describing improve their minds at the expense of their souls. Culture, which - 
according to Matthew Arnold - is only one-fourth of life, teaches them nothing about the vital threefourths - conduct. The men are busy making money - they have no time to do anything else; but the wives and daughters are taking French and German lessons, studying Spencer, or Maeterlinck, or Mrs. Mary Eddy, devouring, with an appetite which grows by what it feeds on, the contents of every new book, good or bad, - in a word, eternally busy in widening and deepening the intellectual gulf between the men and themselves.

The men are responsible for this state of affairs. Indeed they brag of it. They are willing to die that their beloved may live. The hotels (and the divorce courts) are full of idle'wives. Why? Because housekeeping in a new country is a synonym of work. Many a good fellow has said to me, "My wife, sir, shall not work, so long as I can work for her."

None of these butterflies are happy. Mark the quality of their laughter. Note the tinkle of raillery. The educated daughter of the West would sooner laugh at you than with you.

This one-sided condition of things cannot be dismissed with a phrase. In all new countries, there is a time when woman is compelled to bear dreadful burdens. Look at the pioneers, - the men who advanced step by step into the wilderness, performing prodigies of labour, hewing down vast forests, reclaiming hideous swamps, irrigating the barren places, for ever working and fighting, the prey of wild beasts and wild men, the heroes, who, despite all obstacles, perhaps because of them, 


\section{Life and Sport on the Pacific Slope}

triumphantly vindicated their unparalleled patience and energy, - these were accompanied by their wives, the mothers and grandmothers of the daughters of the West. Stop and think what these women, some of them delicately nurtured, suffered and endured. Think not only of the physical ills, but of the mental worries and anxieties: the sense of isolation, the impending sword of death and disease, the possibility of what is worse than death, - torture and dishonour.

Is it then to be wondered at that when a brighter day dawned for these men they realised what was owing to their wives? And have they not bequeathed the sense of this obligation to their sons? Can you not hear them saying, "Nothing that this world can give is too good for the women of the West"?

And accordingly she has been exalted, and the hands that placed the idol on high are loath to pull it down. Indeed, so beloved are their women by the men of the West that some of them (a few), who are truly no more than graven images, have been given articulate speech. I know one man, a charming fellow, witty and humorous and the husband of a stupid wife. Again and again he has told me what his wife has said upon subjects whose very names, I am convinced, are Greek to her. I have never failed on such occasions to express my sense of his wife's wit, and upon my soul I am beginning to believe that my Pygmalion really gives his Galatea credit for the good things which he puts into her mouth. Such a husband brings no business cares to his shrine. Often the divinity 
is the last to learn that the worshipper who has decked her with diamonds is on the eve of bankruptcy. But let it never be forgotten that when adversity comes the idol steps quickly down from her pedestal. The shrine is dismantled. The divinity enters the kitchen. And you can wager that she soon learns how to cook an excellent dinner.

Again, in early days the men were many, the women were few, and, as a commodity in the marriage mart, of extravagant value. It is unfair to say that they went to the highest bidder, for Western girls are not mercenary in the sense that applies to the daughters' of Mayfair, but naturally they fell into the arms of the rich rather than the poor. Indeed, a poor man, unable to give his wife the luxuries of life, remained at the mines or on the plains - $a$ bachelor.

Another reason: the last. At a time when vast fortunes were made and lost in a few weeks or months, it was part of the general scheme of things to make hay while the sun of prosperity was shining. The man who had sold a big herd of fat steers, who had struck a rich lead at the mines, who held booming stocks, was not one to grudge his wife a few diamonds or an extra dress or two. Freely they had received, as freely they gave. And so, petted and pampered, with not a caprice left unsatisfied, the women of the West, touched to the finest issues by poverty and hardship, were by prosperity debased and discoloured. Not long ago a friend of mine met a charming woman on one of the big Atlantic liners. She confided to him 


\section{$5^{6}$ Life and Sport on the Pacific Slope}

her plans for her honeymoon. Nothing was wanting, seemingly, but a husband. $\mathrm{He}$ - it appeared - had been left behind in San Francisco.

Let us turn now to the women who earn their own living: the type-writers, the stenographers, the book-keepers, the telegraph and telephone girls, the doctors, and insurance agents. The fact that a girl can and does earn a fair living gives her a sense of independence and a self-possession quite admirable. But often, avoiding the Scylla of ineptitude, she is engulfed in the Charybdis of a too strenuous endeavour. She is pushing behind a coach that already is over-horsed. Whatever she may accomplish to-day, to-morrow must hold for her sickness and disappointment, - the protest of the body feminine against uses to which it is ill-adapted, the protest of the mind whose desires have outgrown performance. There is a loss - who can deny it? - of womanliness. Does this loss to a community outweigh the gain?

Some years ago I walked into my office, and found at my desk, in my chair, reading my paper, an insurance agent. She was tall, well-dressed, and had the impudence and insolence of her tribe. With these weapons she had fought her way past my clerk, and through a door marked "Private." When she saw me she smiled and nodded.

"I'm making myself to home," she said blandly.

"So I see," was my reply.

"Won't you be seated?"

"You are very kind."

I sat down and waited. 


\section{The Women of the West}

"Do you carry life insurance?" she asked.

"I do, madam."

"In what companies, sir?"

"Upon my honour, madam, I do not see how that concerns you."

She explained that she represented a new company, that an exchange would benefit both of us, and so on and so forth. After five minutes of this I said quietly, -

"I am sure that your time is money to you, so I tell you frankly that I have gone into the subject of insurance, that I belong to an old-line company, and that nothing you can say will make me leave it. And so I wish you - Good-morning."

The hint was wasted. For another ten minutes her tongue wagged faster that a terrier's tail. By this time I had almost forgotten her sex.

"Madam," said I, "I made a mistake just now. I perceive that your time is not worth much, not as much as - mine, for instance. I wish you again - Good-morning."

I rose, and held open the door. She rose also, somewhat after the fashion of the immortal Sairey Gamp.

"You are an Englishman," she said, and there was not sugar enough left in her voice to sweeten a fairy's cup of tea.

"I am."

"Yes, you are. And let me tell you, sir, that you are the rudest Englishman I have ever met. Good-morning, sir."

I did not grudge her the last word.

A well-known Californian tells another story. 


\section{$5^{8}$ Life and Sport on the Pacific Slope}

$\mathrm{He}$ was standing in some public office, chatting with other men, when a brazen-faced lady sailed into the room, note-book in hand, interrogation on her brow. She was, it seemed, the moving pillar of flame of some organisation that had concerned itself, amongst many matters, with female suffrage. This Gorgon approached a man, and addressed him, -

"Are you in favour of woman's suffrage, sir?"

"Most emphatically I am not," he replied.

"You are not. Your name, sir, - and your address?"

The man stammered out both name and address. The lady marched on, asking each the same questions. None refused their names or addresses. Finally, she tackled a stout farmer.

"Are you in favour of woman's suffrage, sir?"

"I am not," he replied. "Indeed, I think there are fools enough in pants voting already."

"Sir-r-r-r !!! Your name, your address?"

The stout farmer eyed her calmly. The other men waited a-quiver with expectation. The stout farmer conveyed somehow the impression that he would stand his ground, and vindicate the superiority of the male.

"That is none of your $d-d$ business," said he, very deliberately.

The Gorgon stared into his impassive face. Then she turned and confronted the others. Nobody smiled or frowned. But the sense of the meeting had been adequately set forth by the stout farmer. The lady fled.

There are many such women in the West, and 
they make the lives of their "men folks," as they are pleased to call them, abjectly miserable. The following anecdote, not a new one to Western readers, illustrates the man's point of view. A longsuffering husband was burying his wife. The coffin had been taken from the hearse by the pall-bearers, and was being carried through the somewhat narrow gate of the cemetery. It chanced that in passing through the gate, the coffin was thrust hard against one of the posts. Almost immediately, to the amazement of the mourners, a muffled scream was heard. The lid was hastily unscrewed. And, lo! the woman was not dead at all. She was taken home and lived for three more years. Then she died again. At the funeral, as the coffin was being lowered from the hearse, the husband addressed the bearers very solemnly: "Boysmind that post."

We come now to the Western woman who leads the double life, - the life of the peasant and the gentlewoman. There are hundreds of these between San Diego and Victoria, nay, thousands, who, as a factor in the future of the Pacific Slope, challenge attention - and pity. Personally I can conceive nothing more pathetic, more heart-breaking, than the spectacle of a gently nurtured girl constrained by poverty to bake and wash and sweep, to play the parts of cook, nurse, wife, servant, and washerwoman, and yet, by virtue of what is bred in her, constrained also to dress as a lady dresses, to eat what a lady eats, to read what a lady reads. Here, again, the curse of a new country, the insatiable desire to appear other than what 


\section{6o Life and Sport on the Pacific Slope}

you are and ought to be, grinds these unhappy women to powder. They wish - they will tell you - to keep up with the procession! Where is the American sense of humour? The men know that the double life cannot be lived. Accordingly, they give their undivided attention to business. When success crowns his labours, the Westerner can - and often does - apply himself diligently to art, or letters, or politics, and the powers of concentration that made him a man of money serve also to make him a man of culture; but what chance has the woman who wishes to make soup and poetry in the same place and at the same time? She is sure to forget to put salt into either. It is easier to bale out an ocean with a pitchfork than to live successfully the double life. Think of Browning and-basting, of a crying baby and French irregular verbs, of kitchen odours and Herbert Spencer. The end is inevitable. These women die, worn out. Before their first boy is breeched the colour and form and fragrance of life have fled. And they leave to their children what? A taint, in a sense, as of scrofula, the stigmata of the suffering and sorrow that wait on failure. These children in their turn will try to shave Shagpat. Their mother, in the attempt to do two things at once, has given them indigestible food for mind and body. Upon the graves of these unhappy women should be inscribed the famous French line: "Malheureuse est l'ignorance, et plus malheureux le savoir."

A feature of home life in the West to which so far as I know - no writer has drawn attention, 
is the gradual backsliding of maternal love and tenderness as the child grows older. This is so insidious as to escape the notice of most persons particularly the parents; but amongst nearly all classes in the West - as in the upper and uppermiddle class of England - there is an animal love of the very young, a wish to cuddle, and kiss, and flatter, and dress, and spoil the little ones, a love which diminishes as imperceptibly, but as surely, as the adored object increases. And the men like to see it. They take the mother at her own valuation. She tells them that she loves babies, that she is $s o$ fond of children; and they believe it! These women always sigh because their children are growing up. The child is, or ought to be, developing, maturing, becoming in short a human being, ceasing to be a kitten or a puppy; and this - say the mothers - is cause for regret. And as a rule, it is cause for regret. The child is growing up to be vain, hard, selfish, deformed in mind, perhaps in body - essentially unlovable. Some wit said that the spinsters of England were the mothers of English gentlemen. He was alluding to the nurses, the governesses, the maiden aunts, the plain elder sisters, who do not perhaps kiss and cuddle, but who patiently and laboriously, day after day, month after month, year after year, shape and prune and water the tender plants committed to their charge. And these are the women whom the men of the world hold cheap! I never meet a mother but I wonder whether her children are denied, not kisses, but that love which finds expression in ceaseless miniștration to the mental and moral faculties. I 


\section{Life and Sport on the Pacific Slope}

know one mother - it is a privilege to know her who is in and of the West. She has no servants, no sister, not even a friend to help her care for her three children. Does she hug her little ones in public? Not she. But she gives them hours of patient teaching and gentle correction. And when her children grow up she will have her reward.

There are many such in the West, but there might be so many more. And, mark you, the "animal" mother, beneath the veneer of tenderness is hard - hard as the nether millstone ; and her hardness grinds to powder the gawky hobbledehoys and hoydens who are not a credit to her whom they have the misfortune of calling - mother!

Some of my readers will remember a paragraph of Daudet's in that delightful book Fromont Jeune et Risler Aîné. It is so pat that I cannot forbear quoting it: a translation would spoil it.

"Ce que Sidonie enviait par-dessus tout à Claire, c'était l'enfant, le poupou luxueux, enrubanné depuis les rideaux de son berceau jusqu'au bonnet de sa nourrice. Elle ne songeait pas aux devoirs doux, pleins de patience et d'abnégation, aux longs bercements des sommeils difficiles, aux réveils rieurs, étincelants d'eau fraîche. Non! dans l'enfant, elle ne voyait que la promenade. ..."

The women of the Pacific Slope have indirect control of the churches and schools. We are told that "the hand that rocks the cradle is the hand that rules the world," but in the West it not infrequently happens that in attempting to rule the world, the cradle is allowed to stand still. Work is 
done in churches and schools that might be better done at home. It would seem as if the women of the West, living in a country where everything is on a large scale, were absolutely unable to see what is small. With their eyes fixed on the mountains they ignore the molehills. The men will tell you, with a fine disregard of ancient wisdom, that if you take care of the dollars, the cents will take care of themselves. Such matters are ordered better in France. There the men make the francs, and the women save the centimes. But in the West the dollars made by the men are squandered by the women. And the children buy candy with the cents.

Perhaps the word "squander" is ill-chosen. The Western woman is keen to get what she calls "value received" for her money. She will spend a morning as lightly as a dollar, looking over samples at a drygoods store. Generally speaking, she buys something unsuited to her station in life and her husband's monthly income. You see more trash upon the counters of Western shops than anywhere else in the world: cheap shoes, cheap clothes, cheap jewelry, cheap underwear. What is plain and serviceable finds no favour and no sale.

Some of the men and women who think about these things have said to me that what is wanted is an example: a Roosevelt in petticoats, who will preach and practise the gospel of simplicity and thrift. One cannot help feeling that such work now that the war is over - might be undertaken by the Red Cross Society. Comfort is one of the most alluring words in the English language, but in 


\section{Life and Sport on the Pacific Slope}

the West it is found for the most part only in dictionaries. It is conspicuously sacrificed to show in the palaces of the very rich, and it has never entered the cottages of the poor. You may find it in the homes of what would be called in England the middle class, especially amongst the Jews, but even here it is jostled and pinched by its bastard brother Display. The women of the West are very hospitable, but at their luncheons and dinners you are sensible that too much is attempted. A lady with one servant entertains upon the same scale as her neighbour who has four. Many of the dishes she has prepared herself; and in consequence she comes to table a physical wreck, unable to eat, unable to talk. In such houses a famine follows the feast; after the guests have departed the mistress takes to her bed.

Speaking of examples, it is a pleasure to cite Mrs. Phœebe Hearst and Mrs. Jane Stanford. These ladies own and control many millions of dollars. They are the widows of two senators who began life poor and obscure men. Senator Stanford was one of four who conceived and carried to a successful issue the building of that colossal railroad which linked the West to the East. Senator Hearst was a famous miner. The bulk of their fortunes will eventually be absorbed by the two Universities of California. One can conceive no nobler use for great wealth than this: the endowment and equipment upon the most munificent scale of institutions whose doors stand open to all who are worthy to enter them. To this single end Mrs. Stanford has devoted her fortune and her life. It is a fact that 
when the Leland Stanford Junior University was in sore financial straits, she denied herself no sacrifice, living in poverty and seclusion until the dun days were past. More, at an age when most women count themselves entitled to rest in peace, she mastered those difficult arts by which alone great trusts are properly administered. She became a woman of business, the slave of innumerable interests, shifting responsibilities to none, the patient indefatigable worker and executrix. The same may be said of Mrs. Hearst.

To women such as these, the Pacific Slope owes an incalculable debt. The money, vast sum that it is, which they give is the least part of that debt. The sleepless nights, the anxious days, the physical exhaustion - can these be computed?

'The girls of the West marry for love. Very often the daughter of a rich man, accustomed to every luxury, marries a poor clerk, or a struggling lawyer or doctor; and while the struggles last she almost invariably proves a loyal and tender helpmeet. Adversity would seem to link such lovers with golden fetters; prosperity tears them apart. It is curious to note that the rich father rarely makes his daughter an allowance, no matter how sharply poverty pinches her. There may be virtue in this Spartan discipline (I believe there is more than we suspect), but to English eyes it appears unnecessarily rigorous. There is a true story of a millionaire who gave his daughter a very large fortune when she came of age. Later, she married against his wishes a poor man, and the father said 


\section{Life and Sport on the Pacific Slope}

bitterly that if he had been vouchsafed a glimpse of the future, his daughter would liave gone penniless to the man of her choice. The daughter, with her husband's consent, in accordance, perhaps, with his wishes, returned her fortune to the father - and he accepted it.

The women of the West have undertaken one colossal labour. They have not sprinkled the demon Drink with their tears; they have fought him tooth and nail. For many years it seemed to me that the advocates of Temperance, a synonym in the West for Total Abstinence, were far too radical in their proposed reforms. Myself a moderate drinker, believing then (as I believe now) that a glass of wine with one's dinner is far more wholesome than a cup of strong tea or coffee, and infinitely less injurious than the lime-saturated water of the Pacific Slope, I could find no words strong enough to condemn those who, styling themselves temperate, proved in debate to be the exact opposite. Since then I have learned to look at the matter from the woman's point of view. I must admit, very reluctantly, that nothing short of the knife will cut out this cancer. I hold no brief for the W.C.T.U., I pronounce Prohibition a sorry plank in any political platform, but I do believe that working amongst individuals, fathers, husbands, and brothers, the women are justified in demanding total abstinence; they are not likely to obtain it. It seems almost impossible for the average man of the West to confine himself to a pint of light claret a day. The experiment has been tried again and again; it has always failed. 
And in the past seventeen years I have seen so many seemingly sound apples drop rotten from the tree - gin-sodden and worthless. In England drunkenness is confined to a certain class; the drunkards of the West are ubiquitous. You find them everywhere - except, be it said, in the pulpit. The doctors, the lawyers, the business men are the worst offenders, for they nip, nip, nip, all day long, till they become - as they are called whisky-tanks, and cease, for the practical purposes of life, to be men at all. What has been done to check the growth of this monstrous tumour has been done by the women, and to them be the credit.

There are some public positions which women fill with genuine dignity. At the outbreak of the late war, a Red Cross Society was organised in San Francisco (I think), with branches all over the Pacific Slope. The Society concerned itself with the welfare of the American soldier, and in particular the American volunteer, for whose comfort those in authority had made inadequate provision. One regiment arrived in San Francisco to find itself without rations. It is true that a banquet was prepared for the officers at the Palace Hotel, but the men would have gone without food for twenty-four hours had it not been for the Red Cross Society. It was a flagrant case of Red Tape versus Red Cross, and the Red Cross was not found wanting.

I have found in country-bred girls an air, a grace, a charm quite irresistible. And you cannot classify them collectively. The typical Western girl does not exist. Each is unique, a study in white, or red, 


\section{Life and Sport on the Pacific Slope}

or blue, or yellow (primary colours, mark you); each appeals to the curiosity, not to mention the cupidity, of the male ; each, too, has a chameleon-like facility of adapting herself to her environment without sacrificing an iota of her personality. Many Englishmen waste valuable time in making up what they call their minds upon purely domestic matters. In the West, the daughters generously assume this task. Without the circle of politics and business, the young American man follows wherever his sister, or some other man's sister, may lead. About this spinster, moreover, are no skirts of compromise: those clogging garments which cramp and compress the walk, the talk, the very thoughts of the English miss.

Perhaps the common denominator of the young women of the West is a magnificent charlatanerie; an imposture that would be ridiculous if it were not sublime. Each pretends to be what she is not; each thinks herself the superior of the women in the classes below hers, the equal of those in the classes above; each strives to appear cleverer, younger, wittier, and prettier than God intended her to be. Indeed, it is an impertinence to speak of them as women; they are all - ladies. And all are ambitious. The ambition of the wife spurs the husband to efforts beyond his strength. Living as they do in the country of infinite possibilities, the humblest unconsciously try to fit themselves for positions that but few are destined to occupy. I remember, many years ago, being accosted by a tramp, who asked me for money wherewith to buy " a bite of something to eat." I gave him a small coin, re- 
marking that in my opinion he was likely to spend it on "a bite of something to drink." As he moved away, ragged and forlorn, my father-in-law, who was with me, said soberly: "You should not cut jokes with free-born American citizens. That fellow may live to be senator of this State."

The balance must be adjusted between the woman who does not work at all and the woman who works too hard. I am of opinion that a radical change is taking place in the hearts and heads of the women themselves. I have already said that adversity brings out and develops what is best in the Western woman. The hard times have given them a clearer perception of values, a saner common sense. Environment is more potent than heredity. The New England women, for instance, bring with them to the West the qualities that distinguish them, - a love of truth and duty and renunciation; and as a rule these good gifts abide with them till they die. But their daughters born in the West will be of the West; and as the West changes, sloughing its skin, so will they change, in obedience to the laws of evolution, till they stand at length, strong and triumphant upon the pyramid of experience, not what they are to-day, but what they ought to beto-morrow. 


\section{IV}

THE CHILDREN OF THE WEST 



\section{IV}

\section{THE CHILDREN OF THE WEST}

T $T$ has been said that the pioneers were the salt 1 of the earth, but their children have been reared for the most part as if they were sugar. A man who has practised rigid self-denial, who knows - none better - what he has lost, as well as what he has gained, and who, perhaps, lacking a perfect sense of proportion, is apt to overestimate the value of advantages he has been forced to forego, - an academic education, for instance, culture, sport, in fine, the amenities of life, - such a one, sitting alone in his counting-house, may well swear that his children shall drink freely of the s cup denied to him. And how can he - poor fellow - be expected to foresee the results: intoxication, folly, bitterness?

Many a father in the West has said: "My son is not like me; we have nothing in common."

"Why should he be like you?" one might reply. "You have kept him in cotton wool; you have humoured his whims; you have taught him to consider himself alone. Now you complain that he is selfish, indolent, and extravagant. Who made him so?"

This question the fathers of the West are unwilling to answer. One can conceive no more pathetic condition of affairs: a father successful 


\section{Life and Sport on the Pacific Slope}

beyond the dreams of avarice, conscious of powers turned to rich account, respected and admired by his fellows, a pillar of his State, and yet sensible that in the greatest thing of all, in the administration of the most stupendous trust, in the care and culture of his own flesh and blood - he has failed; that he has killed his best-beloved son with - too much kindness!

This kindness, as in the case of King Lear, often breeds rank ingratitude, especially amongst the poor. Here is a story - I cannot vouch for the truth of it - which illustrates a relation that too often exists between son and father. The son is speaking. "Yas - I've had the worst kind o' luck with the old man. I knew he was ailin', so I paid his expenses out from Missourah, and fed him the best o' corn all through the fall and winter. And then, when spring come and I was a calculatin' that I'd get a summer's work out of him, he up and died!"

Throughout the West, in the cottages of the poor and in the mansions of the rich, you will find fathers and mothers the slaves of their children. The poor work their fingers to the bone in order that the little ones may wear clothes quite unsuited to their station in life. Upon a hundred ranches I have seen mothers cooking, washing, sewing, while the daughters of the house were reading novels or playing the piano. I have known a mother make her own underclothing out of flour sacks, when her little girl was wearing silk.

"They can only have a good time once," is the cant phrase of these altruists. 
It never seems to occur to them to consider whether or not the children are "having a good time." Certainly, compared with the children of other countries - France, Germany, England they lack mirthfulness. Perhaps they are sensible, poor little dears, of the sacrifices made on their behalf; perhaps the strife around them, which they passively witness every hour of the day, has entered like iron into their souls; perhaps they, in common with their elders, attempt too much and learn too soon the weariness of satiety. I have talked with little maids of four, who knew that their dolls were stuffed with sawdust. I have seen the same little maids pull down their tiny skirts, blushing. 0 , ye Prunes and Prisms! Ought a little girl of four to know that she has - legs? I remember one miss of seven (a born coquette, by the way) who honoured me with her friendship. She was in my room when I was unpacking a portmanteau, and she took the greatest interest in my coloured shirts. Presently she said softly, "My father buys my frocks, but Auntie gets my underclothes." Then she added, with a queer little stare, "Perhaps I ought not to mention underclothes to a gentleman."

When they go to school, and they go too soon, evil besmirches them. From what I have learned from many parents, it is safe to assert that innocence is seldom found in the country schools of the West. One hesitates to indict a system of education that in many respects works admirably. One knows that a mother who is both cook and housekeeper cannot play the part of schoolmistress. And one sympathises with a natural ambition which 


\section{Life and Sport on the Pacific Slope}

confounds means with ends. If a smattering of book-learning is the be-all and end-all of education, the mothers of the West are justified in sending their little girls to school. If, on the other hand, purity of mind, modesty, unselfishness, be deemed a maiden's triple crown, she had better stay at home till she is old enough to know evil when she sees it, and, so knowing it, choose the good.

When I first came to California, the girls, with few exceptions, enjoyed unrestrained liberty. They scoffed at apron-strings. They walked, and rode, and drove alone with the man of their choice. The mothers always stayed at home. They said proudly that they could trust their girls. This trust was a beautiful thing, quite ideal, but how often was it betrayed! You must ask the doctors, read the records, and talk with the young men who take the girls to the picnics and dances, and when you have done all this you can answer the question for yourself.

In a country town, you will find the streets full of girls. They are sent alone on errands; they loaf about the station and post-office, they walk arm in arm up and down the thoroughfares. They ought, every one of them, to be at home working, helping their mothers, who-heaven knows! - want all the help they can get. And yet these same mothers admit that their girls are a hindrance to them in the kitchen and the laundry. "Bless you," said one hard-working farmer's wife to me, " my daughter could n't cook a meal o' victuals to save her life." From her tone I was left to infer that this incapacity was greatly to the girl's credit. In the 


\section{The Children of the West}

West a stream is expected to rise higher than its source. A minute later the mother murmured, "I do wish that you could hear Alvira play Weber's "Invitation to the Waltz.'"

Alvira was sweet sixteen, had attended school since she was six, and what she knew of practical value could have been put into a grain of milletseed.

On the other hand, the boys are encouraged to earn an honest penny as soon as they are breeched. I am speaking of the sons of the poor. Many a small boy, out of school hours, sells papers, peddles tamales, or does "chores," for a neighbour. The money so earned he spends on himself. This of course fosters independence. The boy learns to paddle his own canoe, to shoot the rapids. At fifteen he is - so to speak - a voyageur, a navigator. The father is a "back number."

The conceit of the very small boys, their bumptiousness and braggadocio, always amaze the stranger and foreigner. I read a story the other day that must have been clipped from a Western newspaper. A father leaving home had specially commended the care of the mother to his small son, aged five. That night, the urchin modified his evening prayer. He entreated the protection of Heaven on behalf of the absent sire; but he ended as follows: "Dear God, don't bother about mamma, for I'm taking care of her myself."

My own little boy, a Native Son brought up in California, was very much excited at the prospect of a first visit to England. The battle of Omdurman had just been fought. "I do hope," he said, 


\section{Life and Sport on the Pacific Slope}

after seeing the pictures in the "Illustrated London News," "that the Queen will keep the war in Egypt going - for me."

Another day he was listening attentively to the story of the Golden Calf and the Fiery Serpents. "Well," he remarked, as the Bible was closed, "they were wicked, those Israelites. No wonder God was mad with them. I don't blame him."

Irreverence is a characteristic of the children of the West. This is partly the fault of the pastors. I remember a funeral sermon preached by a Presbyterian minister upon a dead child. The child's play-fellows were in church, and attentive listeners to a discourse mainly biographical. The preacher concluded: "I can see him; yes, I can see our dear little friend;" he looked upward, and the eyes of the children were immediately fixed upon the ceiling of the church. "There he is, corralled in Heaven, playing about with all the other little angels."

This allusion to the corral, that homely feature in the Western landscape, appealed forcibly to the imagination of the children, but surely the ridiculous was too perilously near the sublime.

Speaking of funerals, I recall another anecdote that illustrates this peculiar blending of the sacred and the profane. In Southern California, funerals are, like the Irish wake, a source of entertainment to the many who attend them. If the deceased happens to have been in his lifetime a member of any order, such as the Oddfellows or Freemasons, his funeral becomes a public function, a parade. You march to the burial-ground clad in the uniform of 
your order; a band furnishes appropriate music; at the grave certain rites are observed. But the solemn procession to the cemetery is robbed of its significance, by the rout that follows the benediction. Peace, indeed, is left with the dead. The living race home, as if Death, with the "tiger-roar" of his voice, were pursuing them. After one of these functions I encountered the chief mourner and murmured my condolence. He asked me in return what I thought of the funeral; then he added, before I could answer: "It was fine. Every thing according to Hoyle. Well sir, she'd been a good wife to me, and me and my friends appreciated that fact, and so - we gave her a good send-off!"

Children attend these entertainments.

Talking with the boys and girls of the West, one notes the bias of their minds to what is material rather than ideal. This gives to each child a certain personality - he must be reckoned with as an individual. His egoism is so plainly manifested that it becomes dominant. And this egoism of the child is pregnant with ill-omen for the future of the race. What makes for character - sense of duty, reverence, humility, obedience - is not inculcated by the majority of parents in the West. On the contrary, they encourage the egoism latent in all children, till each becomes an autocrat. I shall never forget a morning I passed in what is called the "Ladies' Parlour" of a steamship. My mother was with me, prostrated by headache and sickness, and the room was full of fellow sufferers. Suddenly a boy marched in playing - toy bagpipes. The 


\section{Life and Sport on the Pacific Slope}

skirl of the pipes at a distance has been known, I believe, to please some persons with Scotch blood in their veins, but the wildest pibroch ever played in Highland glen was sweet melody compared to the strains produced by this urchin. The women glared at him, but he played on, delighted with himself and his toy. His mother was present, unprotesting. Presently he flung down the pipes, walked to the piano, opened it, sat down, and began to hammer the keys with his feet. The mother smiled fatuously. I rose up and approached the child. "You play very nicely with your feet," I ventured to say, as I lifted him from the stool, "but some of these ladies are suffering with headache, and your music distresses them. Run away, like a good boy, and don't come back again."

The child stared at me and obeyed. The mother was furious. Had I been Herod the Great, redhanded after the slaughter of the Innocents, she could not have looked more indignant or reproachful. I was interfering with the sacred rights of the American child to do what he pleased, where he pleased, and when he pleased.

In the East - I am glad to say - Fashion has ordained that the children of the well-to-do shall be quietly dressed, soft-voiced, polite, and considerate. They flaunt no absurd silks and satins, they wear no jewellery, they play neither the piano nor the fool - in public.

In the West it is otherwise.

South of Point Concepcion, the children suffer from the effect of a climate ill-adapted to the de- 
velopment of the Anglo-Saxon race. One hesitates to use the odious word, "décadent" in connection with them, but no other can be found. You will see many pretty faces, whose features lack strength and balance. The lads are pallid, narrow-chested, and rickety; the girls, like the roses, lack freshness and fragrance. There is an exotic quality about them, a quality not without a charm, a languorous grace denied to the robuster children of the North. These are the orchids of the Pacific Slope.

Their precocity is astounding. Most of them are allowed to read the public prints, and in particular the Sunday editions, wherein may be found a special page devoted to the young, and which the young - according to my experience - seldom read. In 1895 we were horrified by a dreadful double murder. Two girls were decoyed to a church, and there dishonoured and despatched by a fiend of the name of Durrant. The case furnished hundreds of columns of what is known in editorial sanctums as "good stuff," and for two years these details tainted the public mind. The very headlines were sufficient to debauch the imagination. To-day, you would hardly find on the Pacific Slope an intelligent boy of fifteen who is not familiar with the details of this murder. Finally, Dewey took the taste of Durrant out of their mouths.

If the mental diet is too stimulating for the children, the food they eat is no less so. Some parents gravely contend that the tissues of a child's stomach may be toughened, like his cuticle, by abuse. One man I know wakes up his children in the middle of the night to eat whatever he fancies: Welsh rarebit, 


\section{Life and Sport on the Pacific Slope}

cold plum pudding, caviare, or pickled clams. "I like my babies around me," he observed tenderly. I feared that he would n't have them long, but he assured me that they were none the worse for these noctes ambrosiano.

All the children of the poorer class eat too much salt meat, and drink tea that is little better than poison. The cooking on the ranches is inconceivably bad. Soda and cheap baking-powders take the place of honest yeast; steaks and chops are fried, not broiled, and served sodden with grease; the vegetables, particularly the peas, are tough and tasteless; the puddings alone are palatable. As a rule, these viands are gulped down in a few minutes. The children fill their pockets with doughnuts (the Western word "sinkers" is expressive) and scurry away to their lessons and games. The elders take a dose of some patent medicine, and fondly believe that they have enjoyed a square meal.

The amount of medicine sold on the Pacific Slope is significant of either stupendous credulity or stupendous ill-health on the part of the people. And the children get more than their share of the drugs. The weakening of a general belief in the Great Physician has quickened faith in the quacks. If Tommy cuts his finger the doctor is summoned; if Mamie coughs, a lung specialist must be consulted; if the baby has a pain, he must be dosed with paregoric. In a country where health once reigned supreme, where doctors were unknown, where drugs were sold by the grocers, you may hardly find today a perfectly healthy family. One child has lost 
his "adnoids," another his tonsils; this one goes twice a week to an aurist; an oculist has just operated upon that; a nose specialist (he won't be long without a name) has the fifth under special treatment, and so forth.

And yet, despite the money spent on them, despite the care and anxiety of the parents, despite the pampering, despite the endearments, the children of the Pacific Slope are emphatically neglected. You seldom see a father or a mother patiently and laboriously teaching a child. The common round is distasteful to the people of the West, the trivial task is abhorrent. The "grind" of slowly imparting to a child habits of self-control, obedience, and a sense of duty is a treadmill that few care to mount. Those who can afford it pay others to train their children for them, and this training is, as a rule, intermittent and ineffective.

The religious training is practically in the hands of the Sunday-school teachers. The more intelligent of these will tell you, if you ask them, that their efforts are often futile, because at home the men of the family habitually make light of sacred things and names. I remember one very small boy who astonished his mother one night by suddenly sitting up in bed and saying, "Well, I am a dam fool; I've forgotten to say my prayers!" Here again is the blend of sacred and profane.

The good qualities of the children of the Pacific Slope are: originality, independence, pluck, and perspicuity. They are extraordinarily quick-witted and plastic, full of quips and odd turns of speech, 


\section{Life and Sport on the Pacific Slope}

and blessed with the strongest imaginations. A grandmother gave me the following. She had explained very patiently the nature of that respect which is due to age from youth. At the end she asked, "Do you understand what I have been saying?"

"You bet I do," replied the grandson (aged six). "I know that it would n't do for me call you Tom."

During a heavy rainstorm, an urchin was seen by his mother to drop upon his knees. "Dear God," prayed the child, "father says we have had rain enough. Please turn off the faucet."

This urchin once begged me to read aloud to him from the paper I held in my hand. I assured him that what I was perusing - the annual statement of one of the banks - would not interest him. He begged to contradict me. So I began: "Capital Stock. . . \$3,000,000."

He interrupted me at once. Stock, seemingly, suggested dairy cows, for he said eagerly: "By golly, three million dollars! Would n't I like to own those cows, and would n't I milk 'em for all they were worth, and sell'em when they went dry?"

Upon another occasion, he had returned from a visit to one of the neighbours' wives, whom he pronounced a perfect lady. I took exception to the adjective and substantive, the person in question being a peasant. "Well," said he, "she may not be a perfect lady, but she 's a very agreeable woman." Upon the deck of a steamer I heard the following: A small boy from the West asked a friend of mine, a striking-looking man, who he 
was. "I'm the pilot," replied he, with a twinkle in his eye.

"The pilot," repeated the urchin, thoughtfully. "Then why arn't you on the bridge?"

These imps criticise their elders and betters freely. A tot said to me quite gravely: "My auntie is not as smart as she thinks herself. And she's often very rude. She cont'adicted me this morning."

A snub - need it be said - is good powder wasted on the Western youth. I remember a lad of eighteen who was selling books. He went into the office of a physician notorious for his crabbed temper, and submitted his wares. The medico bade him be gone, in very unparliamentary terms.

"Can you read?" demanded the youth, blandly.

" Read, sir! I don't read such books as you sell."

"I sell Shakespeare, and the Bible. You don't act as if you had read either. Good-morning."

This same youth - who surely will go far - had heard that at a certain bank the clerks had agreed to hustle any book agent who invaded their premises. The book agent, it must be added, is regarded in the West as a beast of prey. Our young friend took his own line. Rushing into the bank, he exclaimed excitedly, "Boys, have you seen him?"

"Seen whom?" repeated the clerks in chorus.

"That book agent."

“No, no. We want to see him! We're fixed for him. The last fellow made us weary. We're going to skin the next one alive. Where is he?"

"He is - here!" said the youth dramatically. "Start right in, boys, and enjoy yourselves. When you get through I'll sell you some books." 


\section{Life and Sport on the Pacific Slope}

He sold his books.

If they refuse to take a snub, they are quick to take a hint. There is an authentic story of a poor lad who approached a famous millionaire and asked for twenty-five cents (a shilling), wherewith to buy a meal.

"A meal ?" exclaimed the great man. "Why, my boy, twenty-five cents will buy you five meals - of bread and water. And a healthy lad like you can live on two meals a day. I 've done it. Here 's your quarter."

The boy took the coin and the advice. Years after he sought out the millionaire and thanked him.

Since I first crossed the Rocky Mountains, an extraordinary stimulus has been given to all athletic exercises. In 1882 baseball was the only game. To-day the muscles of the youths are hardened and expanded by football, polo, golf, tennis, and bicycle riding. And yet the physiology of bodily exercise is entirely misapprehended, even more so than it is in England. In no country do the young men "scorch" as in the West. You may see them any Sunday upon the highways and byways. Their faces are streaming with perspiration; their eyes are popping from their heads; their brows are seamed with anxiety. Doubled up above the handle-bars they always seem to me the most pitiful notes of interrogation. They are asking for health and strength. What are they getting?

I hold with Walt Whitman that "in man or woman a clean, strong, firm-fibred body, is more 
beautiful than the most beautiful face;" I know, also, what athletics has done for the young men of the West; I am well aware of the many (who might have been drunkards and debauchees) whom a love of manly sport has reclaimed and regenerated. But I cannot blind myself to the fact that in this, as in other matters, the pendulum has swung too far the other way. The strenuous competition that stalks in the market-place rages furiously in the playing-fields, too furiously for the weal of the athletes. In their play, as in their work, would it not be wise for the Sons of the West to give pause? 
1

$+10$ 


\section{V}

\section{RANCH LIFE-I}





\section{V \\ RANCH LIFE - I}

UTSIDERS look at ranch life through rosecoloured spectacles. The word "ranch" has peculiar charm: it sounds more pastoral, more alluring than "farm." A farm suggests hedges, fences, stone walls. Of necessity, life on a farm would seem to be life within bounds, circumscribed by convention, lacking the freedom and freshness of the ranch. A ranch implies ampler pastures, purer air, the essence of Arcadian things.

In the West the word is linked indiscriminately to a score of industries. We have cattle-, horse-, hog-, fruit-, berry-, chickenl-, and even bee-ranches. According to your inclination, according to the amount of capital at your disposal, you may choose any one of these; but remember, you will infallibly fail - losing money, time, and probably health unless you give to your ranch undivided energies, unwearied patience, a fair measure of brains, and a leaven of common-sense.

The writers who have described ranch-life as easy and leisurely, a refuge for men who have broken down in the professions or in business, have - consciously or unconsciously - lied.

On a cattle-ranch, you will be sensible of its remoteness. You are far from railroad and post- 


\section{Life and Sport on the Pacific Slope}

office. Once a week, perhaps, you get papers and letters; once a week you see a fresh face, hear the tones of a fresh voice. The world wags on, but you are out of it. To some this isolation is intolerable; to others, doubtless, it brings comfort and content. The life grows upon one. You rise early, feed your horse and yourself, and ride forth into the hills. After a time you begin to know your cattle; you can see them, distinguish one from another at a distance that surprises the tenderfoot. If one is missing you are aware instinctively of the fact, and glance skyward. A buzzard circling slowly on motionless pinions advises you that the beast is dead, or dying. Perhaps he has mired down in some rotten ground, or is cast in a gulch, or stolen. It is the business of your life to know where the cattle are, and what may be their condition. At certain seasons the calves must be branded; the beef cattle must be cut out, as the phrase runs, the estrays must be given to their lawful owners. These rodeos are the high days, not the holidays, of ranch life. From the neighbouring ranchos ride the cowboys, and in the corrals you will see them at work with the lasso and branding-iron. Time was when cattle were roughly handled. They came streaming across the hills, the vaqueros shouting behind them and whirling their reatas. Now quieter methods prevail. The foreman instructs his men to drive the beasts slowly, not to shout, not to swing the reata. He wants his cattle tame. Even in the corral the lasso is less used than formerly, and the skill of the vaqueros is passing for lack of practice. Some 
,?

; , 30,

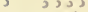

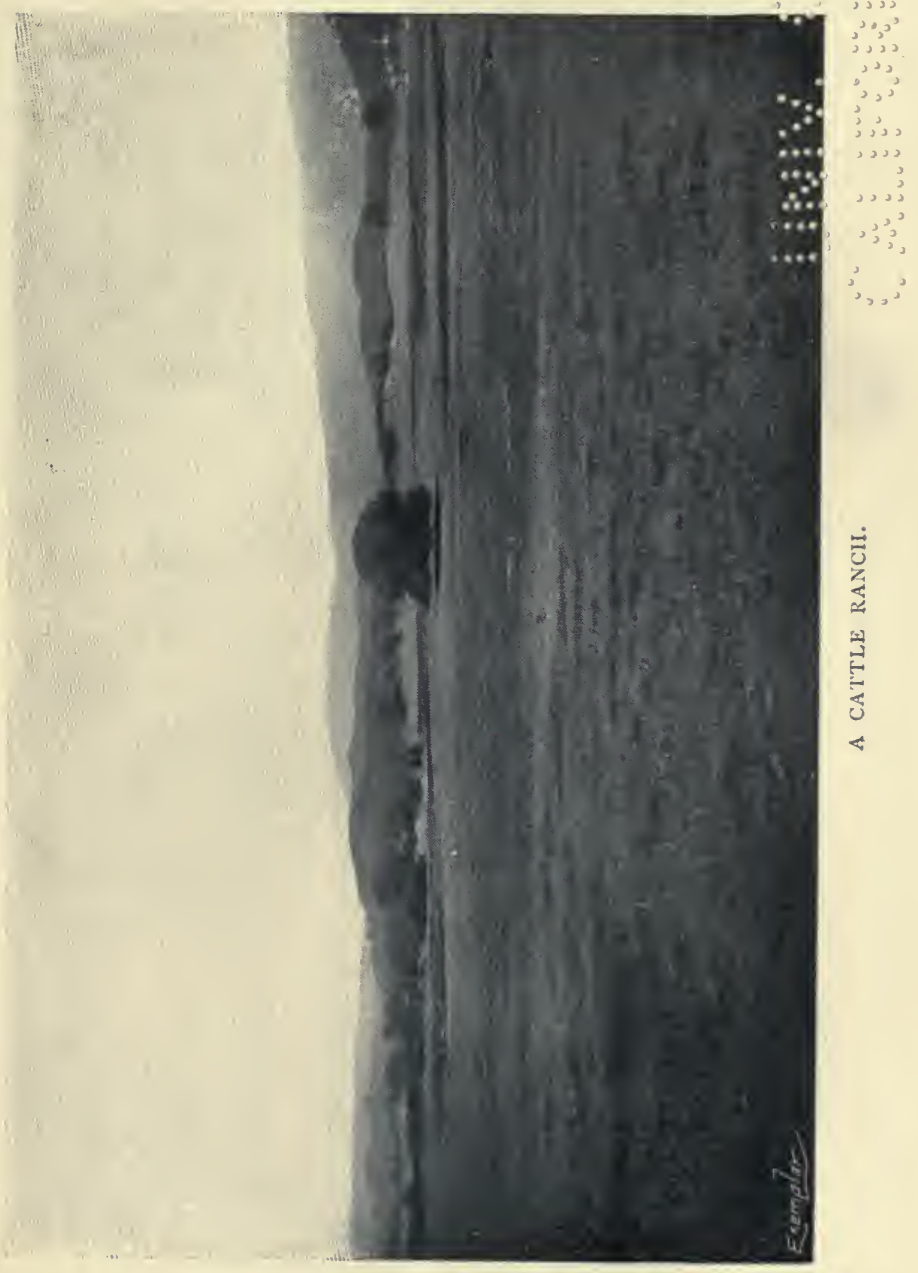



of the "greasers," however, can still fling a rope with such exquisite art that the loop seems to be guided by an invisible hand to the horn or hoof it is destined to encircle; they can vault on, and off, and over, a horse at full gallop, or snatch a coin from the ground as they race by - swinging far out of their big saddles and into them again with extraordinary grace and agility; they can "tail" a bull; they can "tie up" and untie a wild Texan steer, single-handed; and they can break and ride anything that goes on all-fours. In the days before the American occupation of the Pacific Slope the mastery of such feats was part, the larger part, of a caballero's education, and the vaquero was held in high esteem. To-day, poor fellow, his occupation is almost gone.

There is plenty of work to be done on a big cattleranch: fences must be built and repaired; water troughs - where there are no streams - must be filled; the hay-land must be sown to barley, and the crop harvested. You eat the plainest and most unpalatable fare, - bacon and beans, for the most part, with canned vegetables and dried apples and apricots. You sleep in the hardest of bunks, between rough blankets. You wear canvas overalls. You smoke coarse tobacco. But you are strong and well. That is the reason why so many men, who would seem to be ill-equipped for a rough life, deliberately chose it in preference to any other.

As a rule, the cowboys spend what they earn in drink, the most fiery whisky they can find - the brand known as "Sheepherder's delight." After 


\section{Life and Sport on the Pacific Slope}

leading a sober and temperate life for perhaps two months they will ride into the nearest town, and proceed to paint it a beautiful blood-red. As long as the money lasts, all comers are invited to drink. When the last cent is spent the cowboy mounts his bronco and returns to the ranch, where, you may be sure, no indiscreet questions are asked. In the '80's, when southern California was still a pastoral country, these roysterers were anathema maranatha to the townsmen, despite the money they put into active circulation. You may see them to-day jogging into town, astride their wiry, fiddle-headed geldings (your true vaquero never rides a mare), clad in chappareros (long, loose leggins made of stout leather, designed to protect the legs in riding through the tough manzanita and chaparral), and wearing big stiff sombreros tied under the chin by a piece of black ribbon. The dandies are distinguished by a fine silk neckerchief, loosely knotted, by the high-heeled boots (the high heels prevent the foot from slipping through the large wooden stirrups), by the silver mountings of the Mexican bit, by the rawhide bridle and cuerda, by the long buck-skin gloves. Those who wear canvas overalls instead of "chaps" will be careful to turn up the ends of them, so as to display the black trouser beneath, and when they dismount and lounge through the streets, you will mark an easy swagger, the cachet of the caballero.

Drunk, they are dangerous; sober, most capital fellows, - cheery, kindly, without fear, hard as nails, and generous to a fault. From such men Roosevelt recruited his famous Rough Riders, and they 
make the finest irregular cavalry in the world; but they are and always will be-Ishmaelites. They are profoundly ignorant of everything outside their own calling, and always laugh disdainfully at a tenderfoot's blunders. It is best to laugh with them, but sometimes the tables are turned. I know a man, now famous, who once silenced a camp full of cowboys. He had made some trivial blunderI forget what - which provoked the jeers of the "boys." "My God!" he exclaimed, " is it possible that you fellows, born and bred in this cow country, laugh at me? Look here, I have been twice round the world, I speak half a dozen languages, I have lived, lived, mark you, in half the States of your Union, I have met your famous men; and you, you dare to laugh at me because I do not know the one little thing which you know. Well, laugh away, boys. What I don't know about cow-punching is worth a laugh, but what you don't know about everything else in the world is enough to make a man cry."

I have found a warm welcome in dozens of cowboys' camps and never, but once, anything else. On that occasion my brother and I were the unpremeditated cause of the "trouble." We had been camping out in the mountains, and had with us in our spring-waggon a small demijohn of whisky. This demijohn we carefully hid, at the special request of the foreman of the ranch, but the cook, who had not been to town for many moons, found it and annexed it as treasure-trove. It seems that this cook had had "words" that morning with the "boss," and our whisky, in large undiluted doses, fanned 


\section{Life and Sport on the Pacific Slope}

into flame resentment that otherwise might have smouldered harmlessly till it burned out. As we were sitting together after supper, spinning yarns and smoking, the cook suddenly marched into the room, and bade the boss and the other cowboys be gone into the hills, or where they pleased, but off the ranch. He carried my Winchester rifle in his hand, and as he spoke covered our group, which dispersed like a bevy of quail when a hawk circles overhead. In a jiffy, none was left in that room save the cook, my brother, and I. I cannot explain why we stayed, but we had received no orders to go, and we knew of course that the cook had no grudge against us. Then followed a scene, ludicrous enough now, but not so funny at the time. The cook paraded up and down the room, assuring us that he was the King. To emphasise his claims, I remember, he fired into the ceiling two royal salutes, and just then - it being moonlight outside - I saw a dark figure, pistol in hand, flit past the open door. There were two doors in the room exactly opposite to each other. At the same time I saw another figure, similarly armed, at the other door. The King, apprehending danger, brought his rifle to his shoulder, pointing it first to the right and then to the left, according as the heads appeared and disappeared. Meantime he waxed grimly facetious, entreating the gentlemen outside to come in, or at least to stand still, and so forth. The comic side of it did not strike me till afterwards, because I was wondering whether it would not be expedient to lie down upon the floor, out of the line of fire, a position commended by all tacticians of the West. 


\section{Ranch Life}

However, I was sensible that the men outside were not going to shoot first, so I sat still and waited. Suddenly the King's mood changed. He called to one of the men outside, the brother of the foreman : "Say, Charlie, - I'm cold. Bring me my coat; it hangs in the kitchen."

Now drunken men are sometimes as subtle as the serpent, and I decided that if I were Charlie, I should remain outside, and not play the valet, even to a king. Charlie, it seems, was not of my opinion, for he said quite naturally: "That's all right: I'll get your coat." And in less than a minute he was standing in the open door with the coat in his hand. It was a plucky thing to do. The King eyed Charlie, and Charlie eyed the King. There was a light in Charlie's keen grey eyes that was not to be mistaken by a sober man.

"Give it to me," commanded the King.

Charlie held out the coat. The King, with an eye cocked at the door opposite, advanced to take it.

"No funny business," growled his Majesty. "If your brother sticks his ugly head into that door, I 'll shoot you deader 'n mutton."

Charlie - as it proved afterward - had persuaded the others not to interfere. He wanted to play "a lone hand." As the King put forth an arm for his coat, the other jumped like a cat at the rifle - and we jumped too, and everybody else jumped, till there was a big heap of men in the middle of the floor, and at the bottom of the heap the King. Presently we disentangled ourselves, and nobody was left on the floor save he who was no longer King, and the boss. 


\section{Life and Sport on the Pacific Slope}

"You are king, are you?" said the Boss. "Take that!"

He had the monarch by the ears, and at "that" he raised the royal head, and pounded the floor with it, till the foreman entreated him to stop, for the flooring, he said, was rotten. Then the ex-King was handcuffed, and securely tied to a bed. Next day, the boss and the foreman led him to the ranch fence, and explained to him that if he had any consideration for his own health, he must never, never, never come back again. And I am quite sure he never did.

I can tell another story that ends less happily, and which illustrates a peculiar phase of ranch life. Around nearly all the old Spanish grants, the ranchos proper of Southern California, lies Government land, valued by Uncle Sam at one dollar and a quarter an acre. A great deal of this land is worthless save for grazing purposes, and it often happens that the possession of a fine spring or a small creek gives the owner undisputed title to many hundreds of acres not worth taking up on account of a scarcity of water. But when it was proved that some of these hitherto neglected lands were the natural home of certain grapes and fruits, men were eager to file homesteads - as the phrase runs - upon them, and the squatters who had had the use of them for many years naturally felt aggrieved. In some cases they had fenced in these hills, to which they had no legal title whatever. Not far from us was an old squatter who had grown rich upon Uncle Sam's lands. He had, I think, some three hundred and twenty acres of 


\section{Ranch Life}

his own, well-watered, and his stock roamed over a couple of leagues of rolling hills. One day a man and his wife filed their claim to a quarter section (160 acres) of these hills, and began to build a cabin. The first squatter protested and blasphemed - in vain. Finally, he and his son and a nephew deliberately stalked the stranger, and shot him dead on his own land; they also shot and wounded the wife, who dragged herself several miles to a neighbour, and recited the facts. Within twenty-four hours the murderers were locked up in the village "calaboose," and during the following night they were taken out and lynched. The Vigilantes hanged them from a bridge not a mile from our ranch-house, and some children, crossing the bridge on the road to school, found the bodies stiff and stark at the end of two stout ropes. A rope had been provided for the nephew; but at the last moment, as he stood shivering upon the ragged edge of eternity, he was released and commanded to leave the county for ever. He needed, I have been told, no urging. This case has a certain interest, because the old man, it appeared, had not fired a single shot; but it was equally certain that he, and he alone, had planned the affair. Further, he was rich, and the people in our county were only too well aware that in California it is easier for a camel to pass through the eye of a needle than for a rich man to be convicted of murder in the first degree and executed. Accordingly, they very properly hanged an old scoundrel who otherwise would have escaped almost scot-free. 


\section{Io० Life and Sport on the Pacific Slope}

Many persons supposed that my brother and I were amongst the Vigilantes. We were not. We knew absolutely nothing of what was going on, so to speak, under our noses, till the next morning. What knowledge came to us after the event we discreetly kept to ourselves. One young fellow, I remember, a druggist, imprudently hinted that he could tell a strange story if he pleased, and it seems that towards midnight he had been wakened out of his sleep by the Vigilantes passing his drugstore on their way to the calaboose which adjoined it. It was said that the young man looked out into the night and saw a dozen masked men, that he heard the dialogue that ensued between the leader of the Vigilantes and the constable on guard, that he followed the party to the bridge (a most unwise proceeding), and witnessed the lynching. For a brief season this youth was the hero of the hour; then a quiet, middle-aged citizen, a man with a square brow and chin, and a pair of keen blue eyes, was seen to enter the drug-store, and mirabile dictu! - after this the mind and memory of Peeping Tom became a blank. He had seen nothing; he had heard-nothing; he knew nothing. But observant persons remarked that this young gentleman's face, normally as ruddy as David's, had turned of a sudden a dirty grey-green ; so we may infer that the quiet, middle-aged citizen did not call upon his fellow-townsman to pass the time of day, or to buy drugs.

According to the gentlemen who write with ease upon any subject within or without their ken, the West is now tame. My own experience is this: 
a man in search of what is tcchnicelly called "trouble" can find it on the Pacife Slope "very quickly; the man who minds his own business and keeps a civil tongue in his head is as safe in the wildest parts of the West as he would be in London-perhaps safer. Looking back, I can recall many deeds of violence: men stabbed or shot in drunken brawls, stage-coaches " held up" and robbed, trains stopped and looted, banks sacked, and so forth, not to mention the horse and cattle thieves who used to infest our part of Southern California. But to-day, you will find few desperadoes, and those few, like the rattlesnakes, live in the brush hills far from telephone and telegraph. In the ' 80 's it was not uncommon to meet the knights of the road at the taverns and saloons just outside the towns. In our county, during my time, the infamous Dalton gang of train-robbers owned a small ranch. not far from ours. The notorious Black Bart has been pointed out to me. This gentleman always worked alone. Wearing a long black mask, he would not hesitate to "hold up" a stage-coach. When he had robbed the passengers, whom ho paraded in line, he would politely request them to remount and be gone. Then he would pin to the trunk of a neighbouring tree a copy of verses, commemorating the event in quaint English, and signed by himself. I was given to understand that Black Bart was even prouder of his "poetry" than of his exploits as highwayman.

But even to-day, young Englishmen settling upon cattle ranches on the Pacific Slope would do well to mind what company they keep. I remember 


\section{Life and Sport on the Pacific Slope}

one por fellow, the son of a parson, who came to us inany year's ago. He arrived with an amazing kit. Pistols and knives lay meekly by the side of manuals of devotion. He was armed cap-àpie against the assaults of the world, the flesh, and the Devil. My brother and I looked at these weapons and advised the owner of them to keep them, where they were, at the bottom of a portmanteau. But he objected to this, being the son of a man who belonged to a church militant. Then we explained to him that a fight in California was a very different affair to a row with an English rough. It is, in fine, a combat à outrance. At the time I am writing of, if one man struck another, the blow or slap was regarded generally as a deadly insult, only to be wiped out with blood. The man who was struck drew his pistol, if he carried one, and fired instantly. If he had no pistol or knife on his person, he went in search of these weapons, and, further, deemed it no shame to lie in wait for his antagonist, and to shoot him down like a dog when he came within range. If you care to consult the records, you will find dozens of cases of what people in Europe would pronounce cold-blooded murder, in which the murderer has not only been suffered to remain at large, but has won for himself the respect and esteem of the community whose unwritten law he has vindicated. "It don't pay to fool with that feller," is the popular verdict; "he is too quick with his gun." In such cases it is disgraceful to sustain defeat. I knew an Irishman whose daughter had married a crack-brained fellow, the terror of our district. Finally, this Greek met 


\section{Ranch Life}

another Greek, who dropped him dead in his tracks. Shortly afterwards, I was passing the Irishman's house, and marked a red-headed urchin playing on the porch. In reply to my question: "Whose boy is that?" the Irishman murmured mysteriously: "Sorr - 't is me daughter's husband's chi-i-ild." The name of the vanquished and the dead was too inglorious to be mentioned.

The parson's son listened attentively to what we said, but he remarked in conclusion: "Of course I shall be careful, but - " He never finished the sentence; we inferred from the tone that his father's son did n't want to fight, but - ! Not long after he struck a man, a foul-mouthed, drunken blackguard. Before the parson's son knew what had happened, he was stabbed, and he died a few hours later. The man was arrested, tried by a jury of his peers, and acquitted! 

VI

\section{RANCH LIFE - II}





\section{VI \\ RANCH LIFE - II}

N our ranch, we wore canvas overalls. My brother used to say that the unfastening of a large safety pin left him in condition for a plunge into the pool at the bottom of our corral. Yet on Christmas Day (and also upon the Queen's first Jubilee) we solemnly arrayed ourselves in dress things and dined d̀ la mode.

We had many pets. One - a goat - gave us a deal of trouble. He was a remarkable beast, with a cultivated taste for sheet music, and he could swallow, whole, Sunday editions of San Franciscan newspapers: a feat never accomplished by mortal man. If anything was missing on the ranch, such as a monkey-wrench, or a button-hook, or a packet of tobacco, we always knew where it was - inside the goat. Finally he took to roosting on the piano, for neither bars nor bolts kept him out of our sitting-room; and he had a playful habit of approaching you very quietly from behind and then - Bif! We loved that goat, but the time came when we had to choose between him and our Lares and Penates. It was no use giving him away, because he refused to be a party to the transaction, and always came back more wicked than before. Our Chinaman said he was a devil. So he was condemned to death, and three of us drew lots to 


\section{08 Life and Sport on the Pacific Slope}

decide who should be the executioner. I shall not reveal upon whom that lot fell, but the man who slew the goat has never been quite the same since. $\mathrm{He}$ carries the brand of Cain.

We had also a tame pig that answered to the name of Dolly. Dolly was a thoroughbred PolandChina, and she used to follow me about like a dog and eat out of my hand. Dolly became enormously fat, and after a time refused positively to budge from the kitchen door, transferring her affections, after the manner of her sex, from her lawful lord and master to another, the cook, who wooed her wantonly with wash. Dolly was eaten; and we have never dared since then to speak disparagingly of cannibals. We had also a parrot that was possessed not of one but of a dozen devils. Some parrots attain a great age, but this bird died young - I am glad to say. Of course we tamed many colts: a grave mistake unless you intend them for a. eircus. It is easy to teach a horse to shake hands, and waggle his head, and stand on a tub, and lie down; but you cannot teach him a sense of the fitness of things. I remember a black whom I used to drive as leader of a pony tandem. $\mathrm{He}$ was on such intimate terms with me that he never questioned his right to do as he pleased. This perfidious wretch would not only stop when he came to a hill, but also lie down, flat on his back with all four legs in the air, - a disgraceful abject.

Speaking of horses reminds me of an incident. Some neighbours and friends of ours had a horse called Alcalde. Alcalde was a most respectable 


$$
\begin{aligned}
& a^{2} a^{3} \\
& j, 30030 \\
& \text { म 2 } 30 \\
& 0^{3,5} 3000 \\
& \int^{3,25}
\end{aligned}
$$

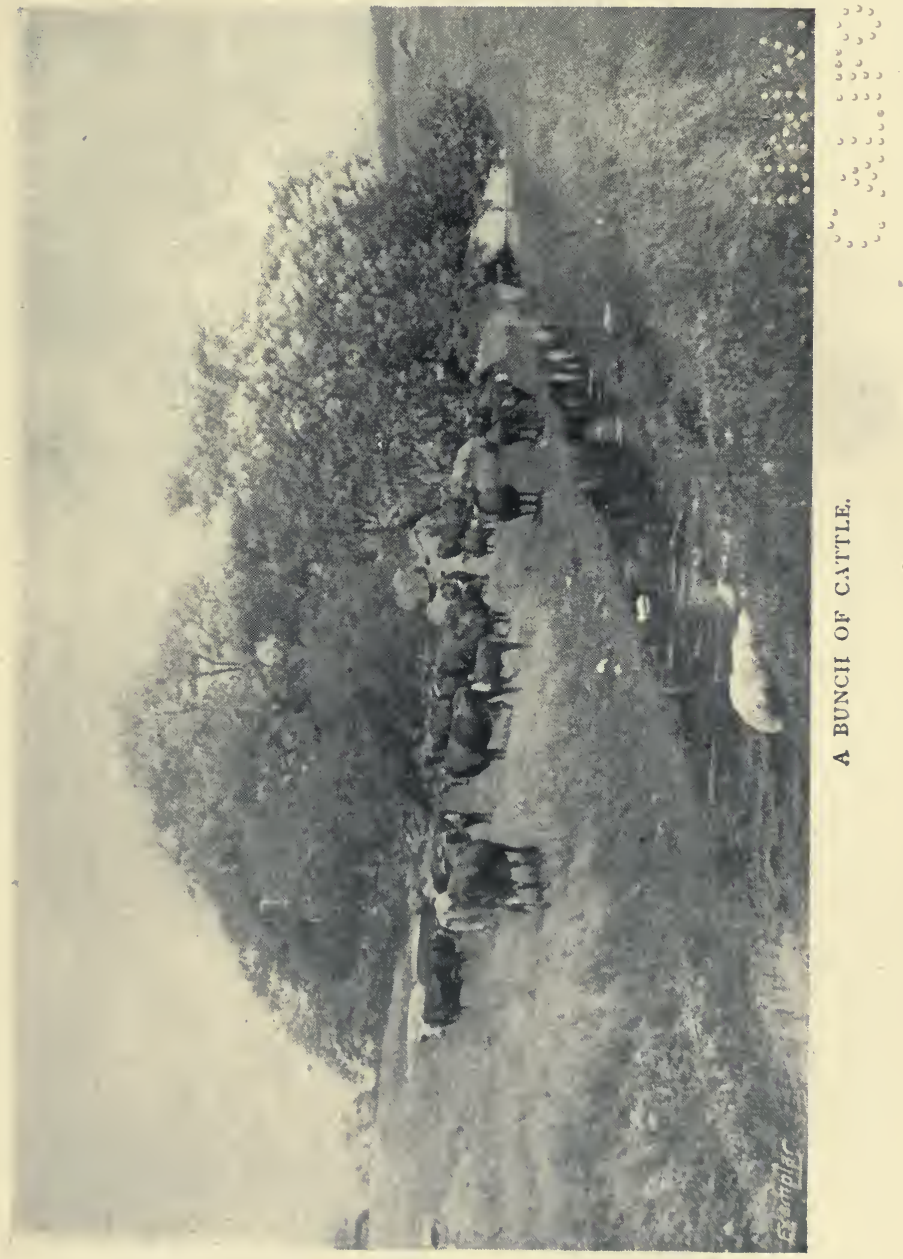



person, but like all of us he had his failing: he would flick his tail over the reins. Now it happened that my friend was of a nautical turn, and in his youth he had learned the art of tying wonderful knots. Accordingly, one day, when he was about to take his wife for a drive, he tied down Alcalde's tail so tightly and so securely that not a wiggle was left in it. Now it happened that only that morning my friend's wife had turned on the water, - water, you must understand, is very precious on a ranch in Southern California, - and, alas ! she had neglected to turn it off, being distracted possibly by household cares; so the water had flowed away, leaving the family tank empty and cracking beneath the ardent rays of the sun. Conceive if you can the wrath of a husband condemned by a wife's carelessness to pump many hundreds of gallons of water! You may be sure that he (he was an Englishman) told his unhappy wife she had committed the unpardonable sin, and she, poor soul, apprehending the magnitude of her offence, held her peace (which is remarkable, because she was a daughter of the West). Perhaps - you may draw your own conclusions - the husband was sorry that he had spoken so harshly, and thought that a drive behind a fast-trotting horse would establish happier relations between two who should be one. Be that as it may, after the drive was over, he began to unharness Alcalde, his wife standing by and talking to him. The traces were unhooked, the breeching straps unbuckled, and then Alcalde was commanded to leave the shafts. But Alcalde, wise as Balaam's ass, never stirred, for he knew that his 


\section{10 Life and Sport on the Pacific Slope}

tail was still fast to the buggy. Thereupon my friend took the whip and applied it smartly to Alcalde's quarters. Alcalde, who had doubtless been nursing his wrongs throughout that afternoon, and who now was given an opportunity, as the lawyers say, to show cause, retaliated by kicking the buggy into a heap of kindling wood. My friend's wife watched this performance with interest, and when it was over she turned to her husband and said quietly: "My dear, after this, I shall turn on the water and let it run as often and as long as I please."

Of the hired men and girls who honoured us by working for wages which an English curate would not despise, I could write currente calamo, but I dare not do it, for I feel like the stout gentleman who remained in the plains, because he was sensible that in the hills he might begin to roll, and go on rolling, till he rolled out of the world altogether. I have so much material that I dare not cut the wire which holds the bale together. One or two stories, however, may be pulled out, without disturbing the rest. We employed a man who in his youth had had an encounter with a circular saw. The saw, in such cases, generally has the best of it; and on this occasion two of our hired man's fingers were left in the pit. Upon one of the remaining fingers he wore a diamond ring! And he actually told me that his hand "kind o' needed settin' off." It never seemed to strike the poor fellow that the proper place for that maimed hand was his pocket. He used to wave it about - so my brother said as if it were a Pampas plume. 


\section{Ranch Life}

Another anecdote illustrates that amazing lack of a sense of proportion which characterises the people of the West. We had a girl, as cook, who was always leaving us to assist at the funerals of her relations. These died one after the other. Finally the mother died, and the girl asked for a week's leave. At the end of the week I drove up to her father's house to fetch Jane, and he (the father) came out to speak to me. Naturally I murmured a few words of condolence.

"Yes," he replied mournfully, "poor Jane, poor girl, she has had bad luck," he seemed to ignore his share in it; "she's lost in one year," he began to reckon on his fingers, "yes, - Tom, Mamie, her uncle Charlie, her mother, and to-day, this very morning, she has lost Dick."

"Good heavens!" I exclaimed, confounded by such unparalleled misfortunes. "You have lost Dick! Let me see, he was your youngest boy, was n't he?"

"No," said the man, gravely, "Dick was poor Jane's canary bird. She thought the world of it. And it died this morning. Too bad, - ain't it ?"

Max O'Rell, in one of his lectures, pointed out the radical difference between the French servant, Marie Jeanne, and the English Mary Jane. "Marie Jeanne," he would say, "puts her wages into a stocking and puts that stocking into a hole in the ground; Mary Jane puts her wages into a new hat, puts the hat on to her head, and gets photographed in it." I wish it were possible to reproduce Mons. Blouet's quaint, ironical accent, and to show you the quirk of his eyebrows. I do not 


\section{2 Life and Sport on the Pacific Slope}

know what he said about the Californian hired girl, - possibly he never had the honour of meeting her.

Many queer characters lived within a small radius of our ranch-house. I dare say we appeared equally queer to them, for I often intercepted winks and grins not intended for my eyes which bespoke a keen sense of the humorous. Reciprocity is a blessed thing, and I am happy to think that we afforded some of our friends as much amusement as they furnished us. One most remarkable instance of how much stranger truth is than fiction came under our immediate notice: a case of Enoch Arden. There were two brothers, and the eldest married a wife, who bore him children. Then, tired perhaps of domestic joys, he sailed away seemingly for ever. Now the younger brother had lived beneath the elder's roof, and he knew that his brother's wife was as gold that has been tried in the fire; accordingly, when the years passed and the elder never returned, nor sent word that he was alive, it seemed good to the younger to marry his brother's wife, which he did, and in due time became, in his turn, the father of several children. And then, like a bolt from the blue, the man who had disappeared reappeared, descending "perpendicular," as Sterne would say, with a "me voici mes enfants!" What happened? If you come to think of it, this is a nice little problem - something akin to Mr. Stockton's Lady or the Tiger riddle. Here were two husbands, two fathers, - and one wife! The problem was solved to the entire satisfaction of all persons concerned, including Mrs. Grundy, who 


\section{Ranch Life}

is not quite so particular in the West as she is in Mayfair. It was obvious, you will admit, that the elder had the law on his side, but only a tenth of it, for the very substantial nine-tenths were and had been for many years in the possession of the younger. It is also obvious that the elder had no such passion for his spouse as, shall we say, Juliet inspired in the heart of Romeo. He had deliberately forsaken her. Still, it is not impossible that he had often repented, thinking, may be, of his children's faces, and the old homestead, and the savoury dishes that his wife could make (for she was an excellent cook). Mind you, he had not been lost in a sub-arctic forest, or living on a desert island, or doing anything, in short, which could be pleaded as an excuse for his absence and silence. The story is tragic from an English or New England point of view. You will say at once that the sailor went back to sea. Not a bit of it. He bought a piece of land hard by, and settled down comfortably as his brother's neighbour. He did not want - so he said - to make any "trouble;" but he wished to see his children, and his brother, and the mother of his children. So he acted according to his convictions, and the people said Amen. It seemed to them, as it seemed to the sailor, the only sensible thing to do.

In the brush hills were many squatters - wild folk, living the primal life, half-clothed, half-starved, drinking coffee made from roasted barley, eating what they could shoot, and not unfrequently what they could steal. A friend of ours, a foreigner, a man of breeding and culture, went to live amongst 


\section{4 Life and Sport on the Pacific Slope}

them. One day, I asked him the why and the wherefore of it. "I will tell you," said he, very gravely. "I have lived, as you know, in ze capitals of ze vorld. And I came to ze conclusion zat society was a big monkey-house, and zat all ze monkeys were trying to pull each ozer's tails. But I will tell you - entre nous-ze monkeys in ze backwoods of California are worse, far worse, zan ze monkeys in society!"

Some of the men, however (they are generically known as "Pikers," because many of them came originally from Pike County, Missouri), if found lacking in the "small, sweet courtesies of life," have, none the less, some interesting attributes. I knew one capital fellow who in happier circumstances would have become a naturalist of note. $\mathrm{He}$ was what is called "a market hunter;" and none was more familiar than he with the habits and habitat of game. He seemed to know by instinct where the big trout might be found, and could catch them with his hands; he was the finest stalker I have ever met; he used to come striding into town with dozens of quail, when other market hunters would tell you that there were no birds in the country; he could always predict the coming of the snipe and wild duck, of which he shot thousands annually; and he was, in his youth, as strong and as handsome as Hercules. Another man was an ornithologist, a daring fowler and scaler of cliffs. He performed the almost impossible feat of robbing a condor's eyrie. These birds are larger than the South American condor, with a spread of wing exceeding 
ten feet, and a beak powerful enough to crack the shank bone of a sheep. Our friend captured a young condor and nourished it successfully for some weeks. Then he asked us to arrange with the Zoological Society for its purchase and shipment, but, unfortunately, before we could do so the bird died. These rapacidæ are only to be found, I believe, in the County of San Luis Obispo, and in the mountains that lie near the seaboard in California Baja. Another Missourian, a cousin of the last, was also a market hunter and a naturalist. $\mathrm{He}$ had made a special study of wild bees, the bees that hive in holes in the steep sandstone cliffs and those also who hive in rotten trees. From the sale of the honey taken from them, from the sale of game and venison (the latter sub rosa) and fish, both seafish and trout, this son of Arcadia supported himself, his wife, two brothers, his wife's mother, and a large family of children! He often told me that he could not work, using the word work in its Western significance; yet, in his own calling, he laboured more assiduously and to better purpose than two ordinary hired men.

I have not entered into a detailed account of our ranch duties, because these will be treated in the appendix.

Of our amusements something may be said. At one time we played polo, and I believe I am entitled to the credit of introducing the game to the Pacific Slope. We used to play regularly in '83, and I should be very interested to know if the game was played West of the Rocky Mountains 


\section{6 Life and Sport on the Pacific Slope}

at an earlier date. The vaqueros delighted in it, and proved amazing players, although it was impossible to teach them team play. Each played for his own hand, and each rode as if he had a dozen lives. I can remember one memorable game when four of us Englishmen played against four vaqueros. Half the county witnessed the match, and the excitement was tremendous: the women standing up in the spring waggons and shouting, and the men betting and cursing. The umpire had a sorry time of it, for our opponents broke every rule, written or unwritten. The game was drawn: each side winning two goals. We should have won hands down had our antagonists ridden ponies like ours under standard size. But we had conceded to them the odds of riding what horses they pleased, and as many as they pleased. So they outgalloped us from first to last. But it was a glorious match! Every man who played was more or less hurt; but no bones were broken, and no money changed hands. Some people imagined that we made the game a draw on purpose. I, as captain, can testify that we played to win, and were within an ace of losing.

We had plenty of fun apart from polo, breaking our ponies and training them to jump. And we practised throwing the lariat, although we never became skilful with it. There were no racemeetings in our county till the County Fairs were organised; but one man would match his horse against another's, and these matches would generally take place upon the Pizmo sands, a magnificent race-course fifteen miles long and fifty yards wide. 


\section{Ranch Life}

Here also were held the clambakes and barbecues: Homeric feasts whereat the meat was hung upon long willow spits, roasted over glowing wood-coals, and eaten with a sauce cunningly compounded of tomatoes, onions, and chiles. These delightful entertainments were given and attended by Spanish people for the most part. The fair señoritas would bring their guitars, and sing those pathetic love lilts which have a charm so distinctive and peculiar and ephemeral, for they are passing with the people who sang them, and will soon be utterly forgotten. After the barbecue, the men would smoke, and often take a nap, and then would follow some feats of horsemanship. A race between a caballero and a man afoot to a post twentyfive yards distant, and back, was always well worth watching. As a rule the man beat the horse on account of the difficulty in turning.

Some of the country dances were amusing. Jack always took his Jill to these functions, and certain unwritten laws were rigorously observed. It was not considered good form to take your partner outside the ballroom. After the dance, you led her to a seat, and, bowing, deserted her. One Englishman, at his first village dance, got himself into what might have proved a serious scrape. $\mathrm{He}$ had no Jill of his own, and being introduced to a pretty one belonging to somebody else, made himself agreeable. The girl danced with him, and was then taken for a short stroll outside beneath those stars which seem to shine more brightly in California than anywhere else - particularly when you are young. I must not presume to say what passed 


\section{8 Life and Sport on the Pacific Slope}

between the pair, but I am sure nothing of more importance than a few idle compliments, for the maid was very pretty, and she danced like a sylph, and the man - I knew him well - could turn a phrase. When they returned to the dancing hall, a waltz had begun, and Jack now appearing to claim it, little Jill was easily constrained to give it to the other. My friend told me afterwards that he marked a ring upon her forefinger, a gold ring with a diamond set in the middle of it, and he was rather surprised when she refused to leave the heated room after the waltz was over. She blushed too when he begged her to go to supper with him, and said, without assigning any reason, that that was quite impossible. The Englishman, unconscious of giving offence, sat down and entertained his partner to the best of his ability. Suddenly, a young farmer strode across the room, and, standing in front of the maid, said in an angry voice: "Give me my ring."

"But - " protested the maid.

"Give me my ring."

As she was pulling it from her finger, the Englishman understood. He had been annexing somebody's best girl! So he rose up, and grasping the youth's arm led him to the door and into the road, where apologies and explanations were offered and accepted.

These dances always began with a Grand March, a very solemn and silent function, a parade of Jacks and Jills walking arm in arm to the sound of appropriate music. During the quadrilles the steps were called by a Master of Ceremonies, the language 


\section{Ranch Life}

used being for the most part French, although I did not find this out for a long time. We, being Englishmen, made a sad mess of these steps - which were often peculiar and complex; but the word "Swing Partners," never failed to adjust our difficulties and blunders. I can well remember one dance in a small village at which this command was given so often that I ventured to ask my partner if, in her opinion, the Master of Ceremonies knew what he was doing. "He's rattled," she replied glibly. "Whenever he forgets, he says, 'Swing Partners,' and while we 're a swingin' he thinks over what comes next. I think 'Swing Partners' more interesting than 'Sachez,' or ' d la main left,' - don't you ?"

Now in those days "Sachez" and "à la main left" were manœuvres executed with great dignity and grace; you accorded your partner nothing more than the tips of your fingers in the latter, whereas in the former you advanced and retreated upon the tips of your toes. But at "Swing Partners," you grasped the young lady firmly round the waist, and were not rebuked too severely if her feet, in the abandon of the pirouette, swung clear of the ground altogether. Such freedom would be eyed askance in the large towns, but I am talking of the hamlets of Southern California - long ago. Accordingly, I assured my partner that in my opinion "Swing Partners" was - interesting.

When you are introduced to a young lady in the country, she will probably repeat your name. Mr. Robinson begs to present Mr. Jones to Miss Smith. Mr. Jones murmurs "Miss Smith ;" and Miss Smith 


\section{Life and Sport on the Pacific Slope}

murmurs "Mr. Jones." If Mr. Jones be English, she is sure to add: "From London, I presume." This always annoys an Englishman of the upper and upper-middle classes, because he does not wish to be taken for a cockney. I can recall meeting two ladies who were not from the country, but essentially town-bred. They too "presumed" that I was from London. I said, "No."

"Perhaps," said the younger of the two, "you have been in London?" and on my admitting as much, she continued: "And perhaps you have met a friend of ours, Mr. Simpkins?"

I regretted that I had not the pleasure of Mr. Simpkins' acquaintance, but the lady was not satisfied. "England" - I make no doubt that her thoughts ran in this strain - "is a small country. These men must have met some time and somewhere." Accordingly she smiled and murmured: " $\mathrm{He}$ has curly hair and he was connected with a large firm, yes, a very responsible firm - the jewellery line. Are you sure you have never met him?"

"Never," said I.

"He had a jealous wife," she insisted; "and his hair was beautiful: black and curly - was n't it, Sadie?"

"He was an elegant gentleman," assented Miss Sadie ; "and his wife was - terribly jealous."

I hinted that curly hair and moral rectitude did not always, so to speak, trot in the same class. I have no doubt that Mrs. Simpkins was not jealous without reason.

In '86 the rise in the value of land, with increased 


\section{Ranch Life}

taxation and a fall in the price of cattle, turned many rancheros into farmers. The big Spanish grants were cut up and sold in small tracts to Eastern and mid-Western buyers. These men fenced their farms with barbed wire, built ramshackle board-and-batten houses and barns, and talked glibly of improvements. Across the fair face of the Southern Californian landscape was inscribed the grim word - Ichabod. In an incredibly short time, the superb trees - the live oaks, white oaks, madrones, sycamores, and cotton-woods - were chopped down. A spirit of utilitarianism was abroad, smiting hip and thigh, sparing nothing, not even the ancient mission of San Luis Obispo. It stands to-day smugly respectable in a cheap modern overcoat of concrete and paint. The picturesque tiles have been thrown to the void; the pillars and arches have been pulled down; and the padres' garden - a cool sequestered pleasance, fragrant with herbs whose very names and uses are forgotten - has been subdivided into town lots!

Once, upon the steps of the church, I met an old Spanish woman, whose withered face was framed in a soft black shawl, most becomingly draped. She chattered of the pleasant yesterdays, and I asked idly if she approved the changes that had been wrought in the ancient building.

"My American friends," she answered in her own tongue, "tell me to wear a jacket with big sleeves, and to buy a bonnet, but, señor, this shawl suits me best. And the Mission was getting like me - ugly and wrinkled; but I wish they had left it - its old shawl." 


\section{22 Life and Sport on the Pacific Slope}

My brother and I sold our cattle, and began to sow wheat in our valleys and on our hills. Some of the neighbours planted out large orchards and vineyards; others opened stores. Churches and school-houses were built. Everywhere, even in the brush hills, was heard the buzz of the big threshing machines, the skirl of the circular saws, the clang of the hammer on the anvil; all the sounds, in fine, of what is called Prosperity.

The tiny hamlet that lay upon the outskirts of our ranch became a bustling village. My brother and I rubbed our eyes, just as Rip Van Winkle rubbed his when he returned to the town that he had known as Sleepy Hollow. But if the dust was still in our eyes, we were soon sensible that those around us were wide awake. The change from past to present was as the contrast between Jacob and Esau. The vaquero, rough, honest, brave, and chivalrous, had galloped away to other pastures; in his place stood the farmer, the smooth-talker, the man of guile, cunning, and crafty. Gone too were the long days in the saddle, gone with the quail and the wild ducks, and the deer and the antelope. Our ploughshares were bright, but our guns rusted in their cases.

On a wheat ranch, the work begins before cockcrow, and it ends when you fling yourself, spent and aching, upon your bed. For in a new country leisure is seldom found on a farm. There is so much that clamours for adjustment and readjustment: trees must be felled and split up into posts ; post-holes must be dug (two feet deep); wire must be stretched; stumps must be taken out; brush must 


\section{Ranch Life}

be burned off; and so forth - ad infinitum. And above us hung the impending sword of uncertainty. Our county had not then passed the experimental stage. Speaking personally, I was always conscious that no matter how hard we worked, that the harvest would be reaped by others: that they would profit by our mistakes.

Of the many mistakes that we made, it is painful but expedient to speak. We planted vineyards and were compelled to plough them up when they came into bearing, because we had chosen varieties ill-adapted to our particular soil; we (I speak now of my brother and myself) planted orchards of prunes and apricots and apples and pears; and they came to nought because we lacked the special knowledge that is now the inheritance of the Western horticulturist; we tried to breed fine fowls, prize pigs, fast trotters, and we failed, not because we lacked intelligence or energy or patience, but because we did n't know how, as a child would say.

And we attempted to do too much, as our neighbours did. To use a homely expression, salted and peppered to suit the Western palate: "We bit off more 'n we could chew."

Upon the ordinary ranch, of course, mixed farming has become a necessity. In early days, you seldom found milk or cream upon the tables of the big rancheros. The wheat farmer bought his vegetables, his hams and bacon, his eggs, his fruit, his Thanksgiving turkey, - everything that was consumed in his house. This policy was justified then by the price of wheat; it can be justified no longer. 


\section{Life and Sport on the Pacific Slope}

The petty farmer, who to-day buys anything at the local store except tea and coffee and sugar and clothes, is either a fool or a spendthrift.

It is so easy to have a "home" on the Pacific Slope: roses bloom perpetually; all fruits and vegetables grow in profusion and perfection; the dairy, the poultry yard, and the hog pen should keep the table abundantly supplied. What ruined the farmers in the hard times was not drought, nor low prices, nor bank failures, but big store bills and big mortgages. If the farmer and his wife and his sons and daughters had been content to wear canvas and fustian, to eat only what was raised on the ranch, to work together - the husband and his sons behind the plough and harrow, the mother and daughters in the dairy and poultry yards - they would have weathered the storm. Instead of this, they kept up appearances. The ranch was mortgaged and crop-mortgaged, and every acre sown to wheat: a dishonest speculation, which proved disastrous also.

I have known some happy farmers - a few. If you wish the soil to bless you, you must wrestle with it, as Jacob wrestled with the angel. And the fight must be-without gloves and to the finish. Kid-glove farmers are the most unhappy of all. And the soil will stain your hands and roughen them; and the hard toil will warp your mind as it will bend your back. Great loss is involved; and the gain may not be easily computed. And yet despite an experience which has been unfortunate, I firmly believe that life in the open air, beneath the genial skies of the Pacific 
Slope, upon a rich and generous soil, ought to be a life worth living.

"The secret lore of rural things, The moral of each fleeting cloud and gale,

The whispers from above that haunt the twilight vale."

These to me have inexpressible charm, a charm the greater perhaps because they may not be lightly apprehended. To the farmer whose heart is in his work, there may, there must come many trials and disappointments, for he is the plaything of the elements, the victim of laws that he cannot control; but there will come also, in the fulness of time, the harvest, the golden sheaves that a man can take with him when he dies. To the farmer in the West whose heart is not in his work, I can only say that it were better for him if he had never been born.

For the seamy side is there: rough, encrusted with frustrated hopes, scored by many harsh lines, like the faces of the women who work too hard. Always you are haunted by the sullen spectre of a dry year, the dry year that comes, it is true, only once in twenty years, and leaves when it does come the hearts of the farmers as colourless and arid as the brown, bleak hills which encompass them. In some years, too, the rain falls capriciously, bringing plenty and prosperity to one, to another want and misery. I have stood day after day watching the green spears of wheat as they turned sere and yellow, bending at last in abject supplication for the moisture that came not; and I have seen, how often! the blight and wire worms 


\section{26 Life and Sport on the Pacific Slope}

ravaging a landscape, making it leprous and unclean. On the orchards and vineyards fall frosts and scale, transmuting the silvery buds into charred cinders, blackening the green shoots and tender leaves till the trees would seem to be draped in crape, mourning for their dead blossoms.

And here, in this land of sunshine, as elsewhere, disease spares not, and if you are living far from town and doctor, you must wait in torment for the help that is so long in coming. Your child, your wife, is dying perhaps, and you sit beside what is dearest to you in all the world, straining your ears to catch the sound of the galloping horse that may bring life or find death.

I have already spoken of the sense of isolation. If you have led the gentle life, if you have depended largely upon others, if your nature craves the friction of human intercourse, if fine music, beautiful pictures, the playhouse, the cathedral, have become to you not superfluities but necessities, then ranch life will surely be hateful and unprofitable.

The domestic difficulties drive some housewives distracted. On a ranch it is hard to keep servants, even if you are rich enough to pay them well for their services. Sometimes, for many weeks, a mistress is compelled to do her own cooking; she cannot buy what she wants from the village stores; the meat is tough and poor in quality; the groceries are adulterated. These things are not trifles.

What affected us more than anything else was the consciousness that we were living in a cul-desac. Happily, my brothers and I had so much in 


\section{Ranch Life}

common that we were more or less independent of others. Yet this very fact contracted our sympathies; our circle, instead of widening, grew smaller and smaller till it contained nothing but ourselves. When we stepped out of it, I remember, we were always amazed to find out how unconsciously we had lost touch with civilisation. Great affairs that were interesting the world that thinks and reads excited in us but a tepid interest; we were queerly sensible that nothing mattered very much except the price of cattle, and the amount of feed in the pastures, - all the rest was leather and prunella.

I have been tempted to dwell only upon memories that grow brighter and more fragrant as the years roll by. How often, after a hot summer's day, I have watched the brown foothills, as the purple shadows were stealing across them. It is then that the breeze from the ocean stirs the tremulous leaves of the cotton-woods; it is then that the cattle wind slowly across their pastures, leaving the cañons and gulches where they have lain during the sultry hours; it is then that a golden haze envelops all things: a glamour as of the world unseen, a mirage so fair to the eye, so cunningly interwoven with fact and fancy, that the realities of life, no matter what they may be, seem to melt away into the gathering shadows.

And after the sun has set, the air is filled with enchanting odours, - the odours of a land that the Lord has blessed, the scent of herbs innumerable, the balmy fragrance of the pines, the perfume of the wild flowers, a pot-pourri of essences distilled by night alone. 


\section{Life and Sport on the Pacific Slope}

These are dear to the sons and daughters of the West: the promise, so to speak, of better and happier days, when life on the Pacific Slope will be purged of what is mean and sordid, purged and purified.

This is the dream of those who love the West. Is it only a dream, a vision of Utopia? It would seem that only cities please a generation not content with rural joys. Worldly wisdom, what Maurus Jokai calls our evil angel, tells a young man that he can never make a fortune on a ranch, which is true. It is also true that the same young man, nine times out of ten, will make no more than a bare living in the town, but this knowledge is withheld from him. Only the very few have the money-making capacity; only the very few can come to their full stature in the over-crowded streets of a big town; the many die in middle age, worn out and weary, sick in mind and body, paupers in all that constitutes true wealth. At the mines, on the cattle ranges, in the orchards and vineyards, on the farms, these same men, working as hard and patiently, would preserve their health, achieve independence, and learn at length the lessons that only Nature can impart, the lessons which teach a man not only how to live. but how to die. 
VII

BUSINESS LIFE 


\section{VII}

\section{BUSINESS LIFE}

SOME years ago, an article appeared in the "Cos$S$ mopolitan Review," entitled: "The Young Man in Business." It was written by the editor of the "Home Journal," Mr. Edward Bok. None reading the article carefully could fail to mark two qualities in it: the sincerity of the writer, and his cock-a-whoop faith in his creed. Mr. Bok, I believe, came to America as a boy with no credentials save those that are inscribed upon an honest face, with no capital save health, strength, and commonsense. To-day he is a rich man, widely known and respected. Some people laugh at Mr. Bok because he caters and caters successfully to a certain class of readers. Perhaps he is, in a sense, the William Whitely of journalism, the Universal Provider. You may be sure that Mr. Bok never laughs at himself - he has n't time. Life to him is a synonym of effort. Watch Sandow when he is putting up his three hundred pound bell; you will mark a frown upon his face. Singers are trained to smile sweetly when warbling; did you ever see a tenor smile when he was standing on tip-toe attacking the high " $\mathrm{C}$ "? Never. In fine, effort warps and twists the face, as it warps and twists the body. This was abundantly set forth between the lines of Mr. Bok's paper. The writer spoke 


\section{32 Life and Sport on the Pacific Slope}

convincingly of the fierce competition that rages around all trades, all arts, all sciences. He made it plain that to succeed - as he interprets success - you must not only work hard, you must work harder than anyone else. Whatever pace be set, do you set a faster. If your competitor works ten hours a day, do you work twelve. You must read the books, and those alone, that have a direct bearing on your work; you must talk to the people, and to them alone, who can push your fortunes; you must eat and drink and make merry, bearing in mind the penalties that wait on excess; you must beware of the club, the theatre, the campus, because these will extinguish the sacred fires of energy. I am not quoting Mr. Bok verbatim, but in sum and substance that is what he said. Reading the article, I was sensible that nothing short of this eternal manifestation of energy, this perfervidum ingenium which seems to be the peculiar heritage of the Scandinavian, would prevail. The mere recital of what ought to be done made my bones ache.

Since, I have never thought of Mr. Bok without thinking also of the fable of the two frogs. The frogs, you will remember, fell into a bucket of cream. One of them, conscious of weakness, knowing that night was coming on, that he could not scale the slippery sides of the bucket, that it would be hopeless to try to keep afloat till morning, incontinently drowned. The other struggled and struggled, and was found next morning by the milkmaid alive and well - upon a pat of butter! We are not told any more; but you may be sure that the hero sang the song of the churning to all the frogs in Frog- 


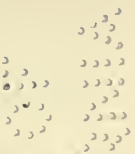

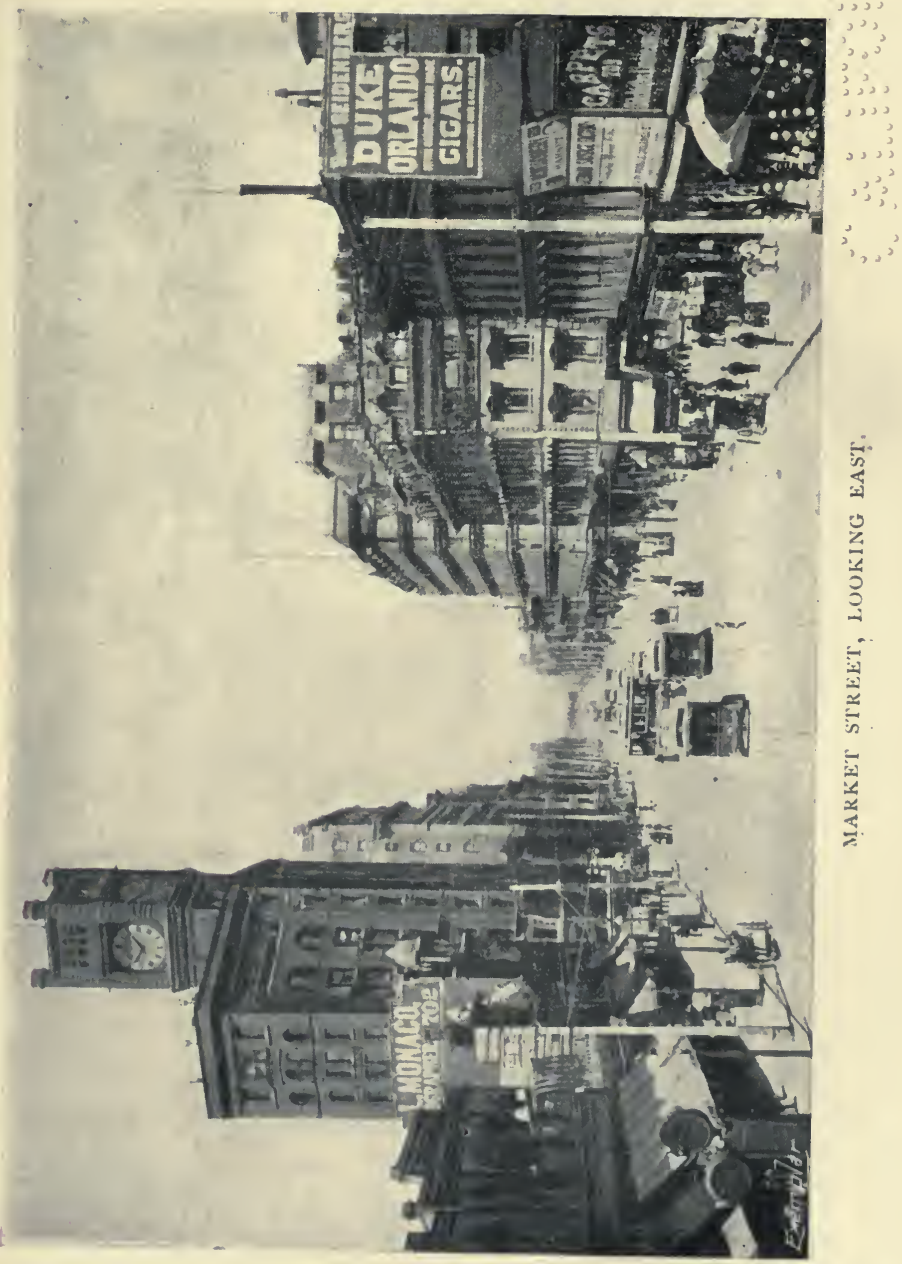





\section{Business Life}

land, and became a great and shining example to his race for all time.

Now Mr. Bok's paper - as has been said - laid stress upon the comparative value of effort, but he laid still greater stress upon the superlative value of concentrated effort. According to him, it is necessary to place all your eggs in one basket - and to watch that basket.

Unhappily, this advice does not commend itself to the Native Son of the Golden West. He likes to place his eggs in many baskets; and then he sets himself the task - thereby wearing himself to skin and bone - of trying to be in two places at one and the same time, - like Sir Boyle Roche's bird. If you had access to the ledgers of the men who have become bankrupts in the last decade, you would find, under Profit and Loss, that the profits made in the bankrupts' regular business had been squandered and lost in half a dozen or more wild-cat enterprises. They will generally plead in extenuation that they have had bad luck; which reminds one of the story of the man who murdered his father and mother, and then invoked the mercy of the Court upon the ground that he was an orphan.

In a certain town I know there is a sign, upon which is inscribed the following legend:

"Home-Made Bread: Job Printing:

RUbBer Stamps."

Bread, of course, demands in the making clean hands; job printing is more defiling than pitch. One person was baker, printer, and rubber stamp 


\section{Life and Sport on the Pacific Slope}

manufacturer. I ordered a rubber stamp, and arranged to call for it at a certain hour. It was not ready at the stipulated time, because - so said the baker - the dough had been troublesome that morning. When I called again later, the stamp was still unfinished, because - so said the printer - some job work had been promised by noon, and as the dough had not risen properly, the type-setting had been necessarily postponed. It was a case of Stick won't beat Dog; Dog won't bite Pig ; \&c.

This robbing of Peter to pay Paul is the particular sin of most Western business men; it clogs the wheels of progress; it palsies prosperity; it keeps capital seeking investment in the vaults of the banks. In hard times it spells stagnation. After the collapse of the land boom, I heard many a man say : "I have to pay what I owe, but nobody pays my bills receivable." (A curious perversion of fact. No money changed hands at all. In the county where I was living at that time, we went back to the primitive methods of bargain and barter.)

This state of affairs is profoundly immoral. It obscures all distinctions between meum and tuum; it makes honest men thieves against their will. Amongst a people who venerate evolution, and regard the word as a fetich, who inscribe upon their coins E Pluribus UnUm, this policy, if persisted in, will surely achieve degeneration and disintegration.

That I am speaking within my brief, none will dispute who is familiar with the history of Banking in the West. We have, it is true, Bank Commissioners, who are paid by the people good salaries to 
perform certain duties, involving a periodical examination of the business done by the banks, a report upon their financial condition, and, if this be deemed unsatisfactory, certain powers plenipotentiary in regard to a change of management, or, in extreme cases, the suspension of payments. The laws upon this subject could hardly be bettered; the administration of them has become a farce. The Commissioners are often ill-chosen; their work is too hastily done; they consider the feelings of the Board of Directors, whom they know personally, rather than the depositors; and consciously or subconsciously they conceal rather than reveal fraud. I used the word subconsciously advisedly. There is a sentiment in the West, underlying all conduct, which the Native Son fondly calls tolerance: a sentiment which wilfully blinds itself to things as they are, and prattles sweetly of things as they ought to be. In a country where the unforeseen nearly always happens, the Bank Commissioners doubtless justify themselves by predicting good whenever they are confronted by evil. Spero infestis should be taken as their motto. It is obvious that these gentlemen should be compelled to do their duty, or their office abolished. At present, they are a menace to the community, who, for the most part, have faith in them - a faith sorely tried of late. I know of cases when unhappy persons allowed all they possessed in the world to remain in the keeping of those whom the Bank Commissioners publicly proclaimed to be solvent and trustworthy, and who were proved shortly afterwards to be neither the one nor the other. 


\section{36 Life and Sport on the Pacific Slope}

An anecdote illustrates the point of view of the Bank Commissioner. I can vouch for the truth of it. A man was indicted by the Grand Jury for embezzlement. At the trial it was abundantly shown that he had misappropriated money held in trust by him. But the verdict of the jury was Not Guilty. A friend of mine remonstrated with the foreman. "Oh, yes," said that gentleman, " he took the money sure enough, but, you see, the poor devil did n't take much."

Let us return to the Banks. Nearly all the wise men of the West are bankers, or connected with banks, because it is (or was) obvious to them that it is safer to play with other folks' money than with your own. It seemed to these gentlemen, who possessed all the qualities necessary to success save second sight, that land had a certain definite value, a value easily to be determined by the experts in their employ. As a matter of fact, land, like any other commodity, is worth what it will fetch, neither more nor less. Accordingly, in defiance of the principles of banking, large sums were loaned upon real estate, sums tied up for a term of years. During the great boom, hardly a bank in the West refused money to its regular customers when the security of a first mortgage was offered in exchange, and so it came to pass that when the boom collapsed, when bad prices and dry years confronted the mortgagors, when principal and interest became overdue and delinquent, hundreds of thousands of acres fell into the hands of the banks, who were in consequence forced to either sell them or farm them, both 


\section{Business Life}

the sale and culture of land being lines of business which they were ill-qualified to undertake. The land in most cases came under the hammer, and was knocked down to the highest bidder at a price equivalent to perhaps one fourth of what the mortgagor had paid for it. This upheaval of land values paralysed the best brains and energies in the West. Even those who had paid in full for their land, and owed no man anything, were terror-struck. An Englishman suddenly told that the bag of sovereigns he had slowly collected during a life of labour and selfdenial was nothing more than a bag of crown pieces would present an analogous case; and it does not require a vivid imagination to conceive what his feelings would be. It is perfectly true that the fictitious value of most of the lands west of the Rocky Mountains was steadily maintained by those who were unable or unwilling to sell their properties, but none the less it was in the air that we were not upon terra firma at all, but encamped on shifting sands.

"Honour" amongst business men is a delicate question to discuss, but one germane to this chapter. If you talk to capitalists in any of the European cities, they will be certain to impugn the Western sense of honour. These gentlemen draw odorous comparisons between their methods and ours. Judged by their standard, we fall short, - that is certain; because in an old country it pays to be honest, whereas in a new country the Lord would seem to only help those who help them- 


\section{38 Life and Sport on the Pacific Slope}

selves freely from other folks' piles. The Chosen People are a concrete example of this, for they pilfer and prosper after a fashion quite impossible overseas. But I imagine that an impartial judge would pronounce the difference, ethically considered, to be one 'twixt Tweedledum and Tweedledee. We have no "guinea-pig" system in the West; we are not hypocrites; we don't take very much (compared with others); and what we do take is always published in the newspapers. If you read the "Times" diligently, you will come to the conclusion that a rich man can do no wrong; a Western editor will prove to you conclusively that a rich man can do no right. In "Aurora Leigh," Mrs. Barrett Browning speaks of those who sit in easy chairs and damn the rows that stand. The Englishman, snug in his easy chair, is given to cheap condemnation of those who stand, and that is why he is so beloved by the nations. When you have nearly all that the Gods can give, it is not difficult to be virtuous - as Becky Sharp observed.

Of the many in business upon the Pacific Slope who are honest we hear nothing, which reminds me of a story. At the time of the last Presidential election, when the claims of Free Silver were being generally exploited, the following was overheard: "Where are the Gold men?" demanded a Popocrat, a street orator, who was holding forth to a crowd in sympathy with his dogmas, "where are they? I don't see them. I don't hear them. Where are they?" After a pause a deep voice answered: "I'll tell you where they are, they'reat work." 


\section{Business Life}

The live-and-let-live philosophy of the West is slowly changing its skin. Adversity has taught us to check our accounts. Not so very long ago a store-keeper found, after an annual stock-taking, that a saddle was missing. He instructed his book-keeper to charge all the customers who were cattle-men with one saddle. "Those," he argued, "who have not bought a new saddle will protest." The book-keeper obeyed instructions, but not a single bill was protested. Such laxity is no longer the rule, but the exception.

In all big businesses, in the offices of the transportation companies, in the saloons and restaurants, in the hotels and places of entertainment, you will observe automatic tills that register the sums paid, and make peculation upon the part of employés almost impossible. This ingenious machine has taught the employed to rely not upon what they can steal, but on what they can lawfully earn; as a factor in the ethical development of the working classes it is justly entitled to mention. Before it was introduced, employers, when estimating future profits, always deducted a certain percentage for undiscovered thefts. At one time I employed a large gang of Chinamen to cut wood and cord it. They were cunning fellows, and their tricks were not easily detected. For instance, they would pile the wood on a side-hill, or around a stump, or the wood in the centre would be loosely corded, so that the tale of cords, when I, in my turn, sold the wood, would be short. I measured the wood myself, but, despite my intimate knowledge of their heathen arts, I was regularly robbed. 


\section{40 Life and Sport on the Pacific Slope}

Finally, I deducted from the money due to them ten per cent, to cover fraud that had escaped my eye. They did not object to this tax, and my cook said that I was " heap smart, same as 'Melican man." I commend this policy to all who employ Chinese wood-choppers.

I went into active business in the year 1890 , and the business - involving the sale and subdivision of large tracts of land-brought me at once into contact with many sorts and conditions of men: bankers, merchants, journalists, politicians, parsons, lawyers, and of course farmers. Our offices were open from nine to four to all comers, and anything that pertained to the development of the county or state was discussed freely and at length. The harvest moon of prosperity was just beginning to wane on the Pacific Slope, but land was still in good demand, and our correspondence was very large. Every scheme of importance, every enterprise of moment, challenged our interest and attention. To my father-in-law, the head of the firm, was entrusted also the management of a street railway and of a large hotel. An Investment and Development Company, of which I was secretary, and the members of a committee formed for the purchase of a right-of-way for a great railroad used to meet daily in our private room. I mention these things, that may perhaps be considered irrelevant, because it will be seen that being identified with a firm which had done and was still doing an immense business, I had exceptional opportunities of studying many phases of business life, and the characters of business men. 


\section{Business Life}

What impressed me most, I remember, was the fluid nature of the credit extended by capitalists to all willing to buy and improve land. Credit alone opened up the country and developed it. And credit established also a state of interdependence between man and man which brought in its train some curious results. Debtors, sensible that a golden fetter linked each and all of them to a common creditor, Capital, grew fearful of offending that creditor. Many excellent plans devised for the public weal, and for no other purpose, were nipped i' the bud, because men could not be persuaded to vote against the will of those to whom they were indebted. There is no such slavery as debt. From the debtor's point of view, the very cardinal virtues must grovel in the dust before that false god-Policy. In the name of Policy every debtor's knee must bow.

As time passed, men began to chafe beneath their chains, to fret and fume in secret. Finally, the freemasonry of misery binding them together, they began to talk openly of rebellion and repudiation. Debt bred the Popocrat, the Silverite, the man who wanted something in exchange for nothing. Debt set class against class.

Thus it will be seen that credit, percolating everywhere like a river in flood, irrigating the waste places, making the desert to bloom and blossom, accomplished great good and great harm. But the harm is passing away, the good remains. A clever writer once said that if you wish to change a man's character, you must change his point of view. The point of view of the Native Son has changed en- 


\section{42 Life and Sport on the Pacific Slope}

tirely during the last decade. Plastic, quick-witted, eager to excel, with immense recuperative and reconstructive powers, he is not so reckless as of yore; he has learned humility; he is beginning to understand himself - and his limitations. The heart of the Native Son is in the right place, but his head has been cocked at a wrong angle. And you can forgive him much on account of his youth: he is not that detestable object - an old sinner.

The business man of the West burns his candle at both ends. As a youth, his recuperative power is immense; as he nears middle age, it dwindles and flickers till nothing but a spark is left. He never rests. As soon as breakfast is over, he hurries to his office and begins work at once; luncheon is bolted in ten minutes, food not easily digestible being chosen, then more work. His dinner hour finds him jaded, in no physical condition to eat and digest a large meal; yet you will see him consume half a dozen courses with an appetite sharpened perhaps by a cocktail or two. After dinner, does he keep quiet? Not he. The club, the theatre, or his everlasting work claim him. His busy brain responds to the stimulus of debate, or emotion, or greed: it grinds on and on, not even stopping when he crawls, spent and weary, between the sheets of his bed.

An inscrutable Providence has given America the English tongue, a medium of speech unsuited to a people rather Gallic than Anglo-Saxon in their quickness of apprehension and power of articulation: that is why Americans talk French so much 
better than we do - and English too for that matter. But a Volapuk of home manufacture would be better than either for a nation who has plenty to say and but little time to say it in. I remember giving a friend the name of my London tailor. When I saw my snip some months after, he thanked me for sending him a good customer, but he added: "He was a queer gentleman, sir." I asked for an explanation. "He was in such a hurry, sir, that he would n't try his clothes on." That reminds me of another story. I had a large water scheme to submit to a New York capitalist. He told me that his time was so filled up it would be impossible to talk over the matter unless I would waive insular prejudice and discuss business at dinner. I dined with him, bringing maps and reports, and three times during that dinner he was disturbed by men wishing to see him! In apology, he observed that he was sailing to Europe on the following Wednesday, and that his engagements were "crowding" him. "If you are going to England," said I, "let us meet at my club in London, and go into this scheme thoroughly." He stared at me and laughed. "Why did you not tell me that before?" he exclaimed. "I have always a little leisure over there." Then I demanded the name of his steamship. "I am not sure whether I shall sail on the 'Teutonic' or 'St. Louis,'” he replied. "As it is winter I can secure a berth on either at the last moment, and there is a difference of one hour and a half in the times of departure. An extra hour and a half in New York means many dollars to me." 


\section{44 Life and Sport on the Pacific Slope}

Truly does the Western poet sing:

"I look in vain for traces of the fresh and fair and sweet

In yellow, sunken faces that are drifting through the street;

Drifting on, drifting on,

To the scrape of restless feet;

I can sorrow for the owners of the faces in the street."

It is interesting to contrast two faces often seen side by side in Western theatres and places of entertainment: the Anglo-Saxon and the Teuton. The German, stolid, phlegmatic, round, and rosy, has worked perhaps as hard as or even harder than the restless, keen-eyed, sallow-cheeked man at his side; but now he is taking it easy. He does not chatter between the acts to his wife or fiancée; he absorbs the sights and sounds in front of him with evident gusto, but he gives nothing back. The Native Son, on the other hand, is giving rather than taking, he is entertaining his companion, instead of allowing the people on the stage to do so. The German goes to bed to sleep soundly till the morrow; the Native Son lies awake for half the night, pursued by a Comus rout of vagabond thoughts.

Again, ask the German what he reads. You will be surprised to find that a big fellow whom you have contemptuously stigmatised as a beer-swiller has read and assimilated the masterpieces of Goethe, Schiller, and Heine; he talks intelligently of the great historians and metaphysicians; he will tell you of the triumphs achieved by his fellow-countrymen in pathology and therapeutics. But what will particularly strike you, is the man's capacity for absorbing and retaining facts that may prove of 


\section{Business Life}

service to him in his trade or business; his mind is a storehouse, wherein may be found the food best adapted to support and prolong life. The Native Son's mind, on the other hand, is a showroom full of "notions," a heterogeneous collection, containing much that is quaint and ingenious and amusing, but little that is useful and enduring.

If the Native Son has any respect for himself and his race, he must learn to husband his resources, instead of dissipating them. Systematic reading of what is best and most inspiring in our literature, careful attention to exercise and diet, rest and refreshment alternating with work and fatigue, would regenerate the toilers of the West. 
VIII

ANGLO-FRANCO-CALIFORNIANS 



\section{VIII}

\section{ANGLO-FRANCO-CALIFORNIANS}

HAVE already spoken (figuratively) of a stone 1 wall which the Anglo-Franco-Californians have built around themselves. Within that wall may be found a wonderful and exact presentment of European life: English men-servants, French cooks and dresses, décadent pictures, five o'clock tea, eight o'clock dinner, and what is inseparable from all these good things - ennui. And yet a fly lurks within the ointment of their luxury: the sense that by the West they are regarded as a joke, an extravaganza. Within the stone wall is what Disraeli used to call the sustained splendour of a stately life; without sits Ridicule singing ribald songs.

Of the many things English to which Americans have a right to strenuously object, nothing is more objectionable than the stone wall, whether it be concrete or abstract. In England it has definite meaning, a raison d'être, but even in England it is an open question whether the stone wall has not kept out more than it kept in. In the West, the stone wall is an anachronism, more, an impertinence. I do not wish to be misunderstood. Life would be intolerable without a certain amount of privacy The exclusiveness that keeps an uncongenial neighbour at arm's length is justifiable on the plea that 


\section{50 Life and Sport on the Pacific Slope}

his tastes and habits differ from ours. It is not justifiable on the plea that we are intrinsically better. The Anglo-Franco-Californians are accused, perhaps unjustly, of posing as being better than the people who are not upon their visiting lists. Only Omniscience can determine so nice a question; but if they claim to be better, the onus of proving it lies on them; when they have done so, it is probable that the people will cheerfully admit the supremacy. As Professor Peck pointed out, Colonel Roosevelt may be considered an aristocrat, because he has proved himself to be more patriotic, more unselfish, more courageous - better, in fine, than the average citizen.

The Anglo-Franco-Californians have what few possess in the West, - the means and the leisure to do what they ought to do, the things that workaday folks are sadly constrained to leave undone. Many of them soberly realise their opportunities and responsibilities. The spirit that impels Dives to cheerfully loan to exhibitions his pictures, and china, and plate, the spirit that drives him from his comfortable library into the Pandemonium of politics, the spirit that makes him cheerfully endure the hardships and perils of a campaign, is his good angel; the spirit, on the other hand, that drives him to the uttermost parts of the world in search of what can only please or profit himself is his demon, no matter how angelically disguised.

American readers will remember a certain fancydress ball given in New York, and the excitement it created. When an army of the "unemployed" was marching to Washington, when times were 


\section{Anglo-Franco-Californians}

troublous all over the country, when it seemed to thoughtful men that the chain which links labour to capital was about to break, so fierce was the strain put upon it, one of the leaders of society issued invitations to a ball which was to bear the same relation to ordinary balls as the entertainments of Lucullus bore to the every day dinners of ancient Rome. As a matter of fact, the cost of this ball was absurdly exaggerated, but the principle is what concerns us. Much ink was spilt in setting forth the pros and cons of the case. It was shown that so far from the ball being an injury to the poor, the benefits accruing to them from the large sums of money put into active circulation amongst a score of industries would very measurably relieve a vast deal of distress. And yet the sentiment on both sides of the Atlantic set dead against what was termed the elevation of the Dollar. The Ball was a grievous blunder on the part of Capital, because lavish display during a season of want and suffering is and always will be cruelly inexpedient and inept.

The Anglo-Franco-Californians have both added to and subtracted from the prejudice against things "English," - a prejudice that nothing short of an awful war waged by the English-speaking peoples against the rest of the world will be strong enough to uproot and exterminate. Curiously enough there is no such prejudice against things French which are surely not above criticism. I remember a smart equipage that used to be seen daily at Del Monte some years ago. A Californian confessed to me 


\section{52 Life and Sport on the Pacific Slope}

that he did not like it, because it was English. I explained to him that the whole thing, just as it stood, - horses, harness, and vehicle, - was not English at all but Austrian. He eyed me dubiously. Then he said: "Well, it looks English any way."

The American nation borrowed our national air and set to it words of their own. It is now part and parcel of Uncle Sam's dearest possessions, and many of his children fondly believe that Uncle Sam composed the music, just as many English peasants are convinced that the Bible was originally written in the vernacular. In the same spirit, English customs that formerly were eyed askance have been adopted and naturalised.

When the first English drag rolled through the streets of San Francisco, the street arabs flung stones at it, regarding it as a symbol of what they abhorred: the stage-coach, so to speak, of Class Distinction, whereon the few could be driven through life, exalted above the many. To-day there are many drags, and the gutter-snipes cheer as they roll by, freighted with youth and beauty, not because their democratic principles have forsaken them, but because they realise that to them personally the coach brings pleasure and profit, - the joy of beholding a perfectly appointed equipage; the profit of reflecting that one day they too may sit in the seats of the mighty.

I can remember when it was hardly prudent to walk abroad in breeches and leggings. The small boys, if they refrained from throwing stones, would pelt you with ironical remarks. "Give that feller the whole sidewalk - he needs it," was a favourite 


\section{Anglo-Franco-Californians}

observation; or, if you wore white polo unmentionables, "Say, Mister, ain't you forgot your pants?" Anything, in fine, that differed ever so slightly from what they, as Californians, were accustomed to, provoked ridicule and displeasure. Servants in livery (the livery being regarded as a badge of servitude), dog-carts, ponies with hogged manes and bang-tails, knickerbockers, English saddles and harness, and the like, were absolutely hateful to them during the ' 80 's. To-day, these prejudices are evaporating. Indeed, the pendulum is swinging far the other way. I remember being asked to. a luncheon given at the Burlingame Country Club in honour of some distinguished New Yorkers who had acted as judges at the San Francisco Horse Show. We drove down to the Country Club upon coaches belonging to members, and I, the Englishman (the only Englishman, so far as I can recollect), out of all that large party wore the ordinary clothes of the American citizen. The others were attired in the latest sporting fashion. Nor did their garments provoke criticism from the foot-passengers. And yet, not half a dozen years before, curiosity taking me to a revival meeting, I had been publicly apostrophised by the gentleman (white) who conducted the proceedings. It happened that I had been in the saddle all day, and was wearing an old check shooting coat and a pair of well-worn breeches. I seated myself upon the bench farthest from the preacher, and was rather astonished to find myself an object lesson to the assembly. "There sits one," exclaimed the revivalist, pointing a finger of scorn 


\section{54 Life and Sport on the Pacific Slope}

at my coat, "who toils not, neither does he spin. And Solomon in all his glory was not arrayed like unto him." This was so obvious to the meanest understanding that the speaker's assurance seemed superfluous. I know now that he was protesting against a costume that, in a sense, distinguishes the man who rides from the man who walks. The same spirit inspired another gentleman of humour and imagination to enroll himself in a hotel register as "John Jones, and valise," merely because the last entry immediately above his ran: "Thomas Smith - and valet."

I mentioned just now the Burlingame Country Club. The history of that club has, I think, peculiar interest, because it is the epitome, the substantial sum and substance of what the AngloFranco-Californians have accomplished in a single decade. In its way it is unique, because it does encompass and manifest so much that is good in contemporary French, English, and American life. Such as it is, moreover, it must be seriously reckoned with as a factor in the development of the Pacific Slope. It has passed the experimental stage; it stands upon a firm social and financial basis; it has withstood ridicule, envy, and internal dissension. The word club will mislead English readers, for the Burlingame is not, as Hurlingham or Ranelagh, a mere place of amusement, but a colony where people live-some of them all the year round - a colony of persons who have tacitly agreed to obtain, regardless of cost, the comforts of life, and to rigorously exclude the mean, the sordid, and the common. Burlingame is a model village 


\section{Anglo-Franco-Californians}

of the rich. Nature has done much for the place; art has done more. It lies upon the park-like foothills that slope gently to the Bay of San Francisco. In the wooded cañons and gulches may be found the "cottages" of the members, houses built for the most part for comfort rather than show; houses with broad and deep verandahs, with large living rooms, with cosy corners. Within, you will mark no silken and velvet hangings, but the freshest of chintzes, the most exquisite linen, that simplicity, in short, which is so delightful and so costly. Here the women wear the plainest clothes, while the male gladly lays aside his cut-throat collar and assumes instead the soft and becoming stock. But stock and skirt must be cut by an artist. The hypercritic at Burlingame might complain that art had just failed to conceal art. The négligé is too studied. But the whole is amazing. You have polo, tennis, golf, pigeon shooting, bathing, boating, and a score of minor amusements to distract your leisure. You can hire from the club stables a well-appointed four-in-hand, a tandem, even an Irish jaunting car, at a price considerably less than you would pay in London. You have all the advantages of country life in France or England. A pack of drag-hounds - some five and twenty couple of well-bred English fox-hounds meets twice a week during the season. Coaching parades (at the last there were eleven coaches and thirteen tandems), steeplechases, pony racing, flower shows, give the cottagers opportunities of filling their houses with guests.

It will be seen, therefore, that Burlingame, as 


\section{Life and Sport on the Pacific Slope}

an institution of the Pacific Slope, has claims to be considered. But this is exactly what the "others" refuse to do. The funny man uses the place as a peg whereon to hang some ancient jokes; the "oldtimer" condemns it as being "too high toned"; the man who wants America for the Americans pronounces it too English; the moralist insinuates that the smart set are bold and bad; the rake finds it slow; and so forth. Some of these charges are true; most of them are false. The smart set in England is both bold and bad; the smart set in New York is bold, and hopes in time to be bad; the smart set on the Pacific Slope is neither bold nor bad. On the contrary, in contrast to the somewhat lax manners and morals of early days, it is punctiliously conventional, almost Pharisaical in observance of Mrs. Grundy's unwritten laws. At Burlingame, for instance, the ordinary amusements of the gilded youth of the West - gambling, drinking, and debauchery - are strictly tabooed. No debauchee can play polo properly or ride straight across country. No drunkard can play golf. In fact, Burlingame, as an influence for good, has done, is doing, and will do more for the rich and the sons of the rich than even they can estimate. Unconsciously it is setting a standard by which not only the rich but the poor will learn to profit; but this standard will profit neither if it be kept under lock and key.

Of things English (and French) that do not bear transplanting, the Anglo-Franco-Californian had best beware. I remember a story in ( $I$ think) 


\section{Anglo-Franco-Californians}

"Le Petit Journal pour Rire." One Frenchman is absurdly dressed as an English sportsman; another finds fault with his appearance: "Alphonse, tu as l'air diablement bete."

"Ça m'est égal," replies the Anglomaniac complacently, "Pourvu que j"aie le chic Anglais."

On the Pacific Slope the chic Anglais cuts some queer capers. You will find married women bearing crests on notepaper: a solecism not unknown in England amongst people of quality. I told one dame that no woman bears her father's crest, and that it is not the best form to use her husband's; but I've no doubt she thought me an officious and ignorant ass. There is a story in New York of a lady who chose for armorial bearings a shield, argent, with a bend, sinister!

These are the ha'penny matters, but fraught with a certain significance. The English custom of "tipping" servants has also come to the Pacific Slope, where servants receive already enormous wages; nearly twice as much as is paid in England. This might have been left overseas. More, the people who "tip" deem it necessary to give gold, utterly regardless of those whose pockets are lined with silver. The docking of horses' tails, too, in a fly-infested country, in a country moreover where these same horses are regularly turned out to grass, is not to be commended merely because it is English.

But the characteristic which more than any other stirs the spleen of the Native Son, and which is far more easily acquired than an English accent (whioh after all is funny without being vulgar), is 
I $5^{8}$ Life and Sport on the Pacific Slope

that you-be-damnedness which has so endeared Englishmen to all foreigners. Now in England a Cambyses' vein has its uses. It would seem as if the Captain were no Captain without his choleric word, but the same in the mouth of an American - is rank blasphemy against common-sense, kindliness, and humour. I am always impressed by the Briton who buys one railway ticket and occupies a whole carriage. He is so truly sublime, so monumental, that you would like to thank him warmly for the pleasure he has given as a-spectacle. But the Californian, poor fellow, cannot assume the god so easily. When he attempts the Olympian nod, no spheres are shaken - only the sides of the witnesses. An Englishman can look superior. A Californian, stiffening his mobile face into the solemn, stolid, stupid mask of the heavy British swell, looks exactly what he is - an ape. 


\section{IX}

\section{THE ENGLISHMAN IN THE WEST - I}




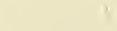




\section{IX}

\section{THE ENGLISHMAN IN THE WEST - I}

A YOUTH, we are told, once swore that he A would fire the Atlantic; on trial he proved too feeble to strike a match! So colossal a failure is pathetic. The abyss between promise and performance may only be spanned by pity or ridicule. And who is heartless enough to laugh at the poor fellow! Did his friends, we wonder, temper his hot braggadocio with cold common-sense? Doubtless. Yet one fears that their attitude towards the weakling was ungracious. Some premonition that the boaster would live to become importunate, a clog, a bore, perhaps a corpse to be buried, soured the milk of their kindness. Sensible of their own merits, his demerits become a reproach, ay, a menace to peace of mind. They might have urged him to fire the Thames, or even a teaspoonful of water; but a failure at home would provoke offensive comment. So they gave him a box of matches and set him afloat upon the ocean.

In this spirit heads of families in England send their fools abroad. If Johnnie fails, he will fail at a distance; and then sorrow at his mishap will be computed inversely according to the square of the distance between father and son.

Johnnie, of course, takes himself very seriously. He is not going to fail, not he. And he studies 


\section{Life and Sport on the Pacific Slope}

profoundly not the getting, but the spending of the gold that will be his. He scatters a largess of promises. The dear old governor shall have that piece of land he covets. The Mater shall spend her winters in the Riviera. Kitty will look sweetly pretty in a pearl necklace. The dear old governor coughs nervously; but Kitty and the Mater kiss Johnnie; and they drop a tear or two together afterwards; for they know in their hearts that Johnnie's promises and cheques will be honoured at only one place, the bank of Love.

Let us skip the farewells, and follow Johnnie to New York. As he is morbidly anxious that he should not be mistaken for an American citizen; he wears a golfing suit instead of the frock coat and silk hat that are as much de rigueur on Fifth Avenue as in Mayfair. Crowned with a cap, he parades his motley up and down a crowded thoroughfare, serenely unconscious that only the bells are missing. However, he lingers not in Gotham. He pines for the Pactolian west, for the boundless plains where he can spread his wings, and soar. So he "takes the cars," and they take him across that wonderful New World, which, despite its amazing charm and beauty, seems so very painfully new to Johnnie. $\mathrm{He}$ is sure to air his impressions in the smoking-room of the car, and he will believe that the bagman by his side, who listens with such courteous interest, is mightily affected. Presently the bagman asks those two significant questions: whence and whither; and in reply to the latter Johnnie confesses vaguely that he means to make his pile somehow and somewhere, but his plans as 


\section{The Englishman in the West ${ }_{1} 6_{3}$}

yet are hardly inchoate. The bagman, who has made plans and brought them to a successful issue ever since he was breeched, abhors a vacuum and tries to fill it. The "filling" amuses the other passengers and does no harm to Johnnie. Soon he is stuffed like a Michaelmas goose, although still unplucked. Alas! the plucking comes after the roasting.

He has now, we will say, reached the Pacific Slope. The sense of distance - the miles that stretch between himself and home - affects him strangely. Contrast colours his opinions, dyes them from drab to red. In a country as yet unfenced, young men, he finds, ride where they please, setting their own pace. Johnnie reflects that if his horse should run away there are no barriers to stop him. This robs the adventure of danger. In England are many pitfalls, many hedges and ditches. Who dares ride across country with a loose rein? But in California -

Who-whoop! Let her go, Gallagher!

Once in Santa Cruz, a bland Mongolian mounted a horse, and the beast straightway bolted in the direction of some steep cliffs. "Where are you going, Quong Wo?" yelled an American.

"I no sabee," replied the Celestial.

In this spirit of nescience Johnnie vaults into the saddle and gives his bronco the spur. He does not know where he is going, but the bystanders know very well.

Sometimes he goes over the cliffs, and that is the last of him. Poor, poor fellow! Who is responsible for this pitiful end? Not he, assuredly. Per- 


\section{I64 Life and Sport on the Pacific Slope}

haps his best qualities have hounded him, hot foot, along the Devil's Causeway. Generosity, pluck, mirthfulness, a desire to please, have brought him to grief. When the dear old governor opens the letter that tells him his son is dead, does he realise that he signed the lad's death-warrant?

But these desperate rides seldom end fatally. Johnnie has a tumble or two, and sooner or later he decides humbly to go a-foot. He will tell you, if you happen to meet him, that he has sown his wild oats, and means to soberly and sedulously seed the future with wheat. This means buying a ranch. None of his people - he assures you have soiled their hands with trade. "I'm not fitted for anything of that sort," he concludes cheerfully; and heaven knows that he speaks truth. So he buys an orchard, a vineyard, a cattle ranch, a wheat farm, or a dairy. You can take your choice, as he does, of these alluring industries. In the end it will make as little difference to Johnnie as it does to you sitting snug in your chair. Whatever basket receives the eggs, they inevitably will be smashed!

Had you the magical carpet, you could transport yourself to his new domain, where your host will be delighted to show you his pony, hog-maned and bang-tailed, and also his keg of Glenlivet (for he is a hospitable chap), and his big canister of tohacco, and "that cañon yonder, where, by Jove, the quail simply swarm, my dear chap," - and many other things animate and inanimate in which at present he is keenly interested. The crops, you may observe, look patchy, as if wire-worms were at work, or the 


\section{The Englishman in the West 165}

trees in the orchard have the scale, or perhaps the "hoppers" are eating the vines, but Johnnie can greet even the woolly aphis with a grin. "It's not quite so simple as I thought it was, this ranching," he confesses over a pipe and a toddy. "I'm-I'm going behind this year; but next year I shall make pots o' money! You bet your life!"

Who is brute enough to retort that so far from betting one's life upon a result so very dubious, it would be folly to hazard a farthing? Yet one is miserably sensible that Johnnie is betting his life, and that the odds are against him.

Meantime he wears his tweeds, and is happy. For a season, knickerbocker breeches made for happiness with Johnnie; so do polo boots, and pigskin saddles, and brier pipes. But the sight of these insignia of the broken brigade brings tears to the heart. It is like seeing a well-cut dress-coat on the back of a tramp. As the years pass, Johnnie's English clothes wear out and are thrown aside; but the breeches remain, stained and discoloured, a symbol of what has been, and what in all human probabilty can never again be. Note the warp and woof of the stout cloth: wool all through, no shoddy. Johnnie too was made of good stuff, and has worn well; but he is stained and discoloured, thin and patched, torn by adversity, a scarecrow. These breeches have other significance. They are Johnnie's protest against the overalls of Western life. They advertise the wearer's contempt of public opinion, his ineptitude, his utter lack of a sense of proportion. Think of thick Scotch tweeds and thick Scotch stockings in hot, dusty Southern 


\section{66 Life and Sport on the Pacific Slope}

California. The mere thought irritates a sensitive skin. Yet you may see these garments any day you please to walk through Los Angeles. There they are in the glare of a semi-tropic sun, as absurdly out of place as a mackintosh in the Sahara desert.

An Englishman whom the writer knows used to drive tandem in California. Once, coming out of a livery stable, his leader slipped and fell upon the asphalt pavement, rolling over like a shot rabbit. He had no groom with him, no friend. $\mathrm{He}$ dared not descend from his lofty perch, because the wheeler was kicking savagely, but some good Samaritan set the leader on his legs and cunningly unravelled the tangled skein of traces and ribbons. As he drove on, these words drifted after him: "It takes lots of trouble to be an Englishman."

Johnnie, of course, despises American whisky and American methods. He drives his four workhorses after the fashion of his kinsman of the Coaching Club. He would scorn to call the reins "lines," or to hold them, western fashion, in both hands; he dearly loves to turn sharp corners smartly. One day he turns too smartly: the waggon is smashed, the horses injured, the harness ruined. "By Gad," exclaims Johnnie. "We took a toss - did n't we?"

These accidents - one a week would be a fair average - are not altogether displeasing to his neighbours. Indeed, Johnnie's little ways have not commended him to the favour of what he calls "the unwashed." He prances upon Yankee 


\section{The Englishman in the West 167}

corns, sublimely unconscious that he is inflicting pain, or, to do him justice, he would be more considerate. Many years ago, a sprig of English nobility called upon a compatriot, at what was then the most fashionable hotel in New York. In the corner of the room was a coaching horn. The mere sight of this filled my lord with a fine frenzy. Before he could be stopped, he had seized and was tooting it with all the strength of his lungs. Bell-boys came a-running, and later a note from the manager. His lordship promised to make an amende honorable. "You see," he told the chief clerk, "I've always understood that in the States a man could toot his own horn wherever and whenever he pleased. So I naturally supposed, you know, that he could toot another fellow's, if he wanted to." This explanation was not considered satisfactory.

Johnnie always gathers round him other Britons as helpless and impecunious as himself. Some of these are remittance men, who go to town when the cheque comes from home, and when the money is squandered return to Johnnie's beans and bacon. Of these gentlemen more will be said presently. They belong for the most part to the rapacidoe, and must not be confounded with either the wild or the domestic goose.

When Johnnie's domain is taken from him (under foreclosure proceedings), he seeks work where he can find it, and the search wears out shoe leather. Farmers know that he failed to take care of his own property; how - they ask pertinently - can he be trusted to take care of theirs? Finally, some com. 


\section{68 Life and Sport on the Pacific Slope}

patriot offers the dole of board and lodging. One man was known to many sheep-owners in Southern California as El Fraile (the friar). An ardent Roman Catholic, he had a prodigious memory glutted with odds and ends of learning: all of it quite unavailable for work-a-day uses. What El Fraile did not know about the ante- and post-Nicene Fathers was not worth knowing. He herded sheep badly, although it was his duty to herd them well. Yet he had a fine sense of humour! One day he was sent to town to buy groceries, and on his return the other herders marked on his usually pleasant face a most villainous and hang-dog expression. Examined, he confessed with groans that the storekeeper, a German Jew, had slapped his cheek. And be had submitted tamely to the insult because without provocation he had kicked the storekeeper's dog! So he had accepted his thwackings meekly as a penance. For a week he moped; then he went again to town and returned to the ranch in fine feather. $\mathrm{He}$ had caught the storekeeper cheating a child, and had thrashed him soundly with a stout pigskin belt. The friar grew very peculiar as time went by, and the vaqueros said that he had surely eaten of the "loco" weed, and was now crazy. His greatest and indeed his only pleasure was confessing his sins. To reach the confessional, no obstacle was too great to be surmounted. In winter, holding a heavy stone in each hand, he would wade through boiling torrents that the greasers pronounced impassable. In his haste to deliver his soul he would outstrip the stage to Santa Barbara. His appearance, you may be sure, was no less disordered than 


\section{The Englishman in the West 169}

his wits: he wore a ragged, grey flannel shirt, a pair of tattered pantaloons, and huge Blïcher boots. Father X-, of the Mission, who was rather particular, and with whom El Fraile loved to walk, gave the poor fellow a long, white dust coat; but the friar, finding it inconveniently long, trimmed off the skirts with a blunt clasp-knife, and when he came to the pockets cut around them, doubtless considering that they were too useful to be sacrificed to mere symmetry. Wearing this mutilated garment, he used to take the air in the padre's company. Finally, he informed his friends that a vision had been vouchsafed him: the Blessed Virgin had personally assured him that he was appointed by Heaven to fill the pontifical throne, and must accordingly betake himself to Rome. $\mathrm{He}$ dared not disobey, he said; so El Fraile, without purse or scrip, drifted away from the ranges and out of our lives.

Requiescat in pace.

Religion, however, offers its sublime consolation to few. As a rule, Johnnie steeps his past in drink. When he audits his accounts with fate and finds that the assets are nil and the liabilities past computing, he throws down his tools and hies him to the demijohn. Some whisky kills quick; but there are Englishmen proof against sheep-herder's delight. One fellow has been drinking it steadily for thirty years. During all this weary time he has received each week from his mother the "London Graphic;" and each week when it comes he staggers to the nearest bar, and exchanges it for one drink! 


\section{70 Life and Sport on the Pacific Slope}

In or out of his cups Johnnie damns the country for his failure. The country, need it be said, is not to blame. No finer country than California lies out of doors. Others - plenty of them-succeed where Johnnie and his friends failed. Had he given undivided attention to his business, he too would have succeeded. But from the start he misinterpreted that grim word-work. He pronounced ranching simple. Had he been taught that nothing in life is simple, that in the strenuous competition of to-day no hour may be wasted with impunity, no dollar squandered, no trifle ignored - had he mastered these, the principia of life's science, he might, who knows, have graduated with honours.

To be crowned with laurel abroad, this sort of teaching must begin at home. Perhaps the fool will never learn his lesson. A youth not clever enough to pass into the army or navy, the Civil Service, or the learned professions, not quick-witted enough for the Stock Exchange or business, a hopeless duffer in short at all that pertains to genteel bread-winning, - such a lamb as this must be kept in the fold, not suffered to stray into the stony places of the world.

True; but what can you do with him at home?

Let him serve his sovereign as a soldier or a sailor in the ranks; let him be apprenticed to some honest trade; let him become a hewer of wood, a drawer of water; let him fill any position, however humble, under the eye and ægis of authority, rather than be driven forth into the wilderness to perish miserably. 
We can hear paterfamilias fuss and fume when he reads the last paragraph. "What! My son an apprentice?" Yes, dear Pooh-Bah, even your son. You and Madam placed that empty head on his shoulders. See to it that it is not filled with lead, or whisky, or worse!

"His sisters must be considered," growls the father. "They will lose caste if Johnnie is selling ribbons across a counter, or working as a labourer in the fields." In this democratic age, it is doubtful whether any person would care twopence what Johnnie was doing. If the sisters were nice girls, they would not lose caste; and if they did find the houses of a few snobs closed to them, what of it? But if Johnnie owes something to his sisters, do not they also owe something to him? Is it right to push a weak-minded lad outside the circle of their influence? Wellington, I believe, in his Peninsular campaign, directed that the lists of certain soldiers reported for punishment should be sent home to the men's respective parishes, there to be nailed up on the church door. Johmnie is just the sort of fellow who would have a wholesome awe of such publicity. He goes to the devil abroad, not knowing his destination, as has been said, but at home he goes to church. However, there may be cases in which it is expedient that Johnnie should be sent to America or the colonies. Then, teach him first a trade. A blacksmith need never herd sheep; a cobbler will never lack butter to his bread. And who would not sooner see his son a good mechanic, rather than a starving, solitary, homeless, and friendless-gentleman! 


\section{72 Life and Sport on the Pacific Slope}

The fathers of the fools are, as a rule, army and naval officers retired on half-pay. What a pathetic procession they make, these veterans of the Crimea and the Mutiny! You meet them in every country town: two and two, marching stiffly, keeping step to the drums and fifes of precedent and prejudice, chests well inflated, clothes well brushed - clean, kindly, honourable men. And their sons - so say they all-must be also gentlemen. God knows one wishes for their sakes it might be so; but is it possible? Is it practicable?

"My lad is a fool," a major-general complained to the writer, some years ago. "What shall I do with him?"

"Don't send him to America or the Colonies unless you first teach him a trade."

"There is no place for my son in trade, sir," replied the veteran, stiffly; "and no place for him at home," he added grimly.

Did this Roman father probe the true significance of his words? Had he no bowels of compassion for the infirmity of his boy? Did he deliberately determine to expose the weakling, to let him die out of sight, whilst he, the father, kept immaculate his bubble reputation as a gentleman? The lad in question was sent forth absolutely unequipped for the struggle (although his breeches were cut by Tautz), and he died. Who killed him?

For the wise, the strong, the patient, and the thrifty there is gold everywhere; for the weak and the witless there is no gold anywhere, only the hard quartz in which the metal was once imbedded. 


\section{The Englishman in the West 173}

In England, the beggar gets the crumbs and pity of the rich; abroad, he gets not bread but stones, not pity but contempt.

In the name of mercy, keep your fools in the family. 


\section{$\mathrm{X}$}

\section{THE ENGLISHMAN IN THE WEST - II}





\section{$\mathrm{X}$}

\section{THE ENGLISHMAN IN THE WEST - II}

TN addition to the family fool, the types of Eng1 lishmen to be found on the Pacific Slope include the parson's son, the fortune-hunter, the moral idiot, the remittance man, and the sportsman.

Of the parson's son one might quote the French proverb : a cobbler's child is not the best shod. It would seem that many of the Children of the Church of England are not shod at all. They wander barefoot through the stony places, kicking furiously at the flints of convention. Win their confidence, and they will confess that the shoes provided by their sires were too tight. Accordingly, they discarded them at the first opportunity. As a rule, they go without shoes to the end of their days - which are not very long in the land of the West. You meet them everywhere: beachcombing by the summer seas of the Pacific, tending bar, selling cigars, herding sheep; and on most of them is the brand of Drink.

The fortune-hunter, on the other hand, is always well-shod in boots cut by a crack London craftsman; and he shuns the wilderness as he would a poor relation. His credentials are his clothes and his impudence. It may be said of his impudence that it passes all understanding and endures for 


\section{78 Life and Sport on the Pacific Slope}

ever. If this gentleman bears a small handle to his name, his ultimate success is almost certain. This is curious, for Western women are not snobs nor vulgar (till they settle down in England, where they soon catch the national disease), and the obvious fact that our fortune-hunter has not been able to secure a mate in his own country would one would suppose - discolour his reputation. Not at all. $\mathrm{He}$ anticipates comment by maintaining that the English Miss is dull, dowdy, and impossible. When the daughter of the West marries the fellow and follows him to England, she soon learns that the English Miss is often dull, sometimes dowdy, and always impossible - to the wrong man.

One girl with a sense of humour and great expectations from a rich father told me an amusing story. A fortune-hunter paid her attentions and finally entreated her - as she put it to me - to provide him with a permanent home. "But," she protested, "I understand that you are engaged, or as good as engaged, to another young woman." The fellow smiled reassuringly. "Don't let that trouble you," he replied. Six weeks later, notwithstanding the snubbing he got from the heiress, he proposed again. "But you are not free to offer me marriage," she remarked; "you are still engaged to that girl." Nothing daunted, the seeker after good board and lodging replied once more: "And I tell you now, what I told you then-don't worry. That little affair can be easily arranged!" "So can this," retorted she. "Don't you dare, sir, to come near me, or to speak to me again."

I have nothing to say against the belted earl 


\section{The Englishman in the West}

(with nothing left but his belt) who can offer a woman rank and position in exchange for her shekels. And who will throw even a pebble at the girl to whom getting the best of everything regardless of cost is a vital instinct, the girl who justifies her upbringing by buying as husband the most expensive article in the market? Such matches turn out indifferently well, because, as a rule, the contracting parties are under no delusion in regard to the nature of the bargain. The adventurer I speak of has nothing to offer an heiress except himself: goods, it is true, upon which he places an extravagant valuation, but goods invariably more or less damaged. Most of these gentlemen assume a military style and title. They have been Captains in crack regiments. But it is indiscreet to ask these warriors the names of their corps, or indeed any questions concerning the past; and what information they do give in regard to such matters needs more than a pinch of salt. The big hotels are the happy hunting grounds of these sportsmen; and it is not easy for an American man to keep calm when he sees them firing - so to speak - into the "brown" : missing many, of course, wounding a few, and bringing to bag perhaps one pretty bird who deserves a happier fate. It is comic - were it not tragic - to study their methods. Listening to the Captain, one might even infer that the American girl is not quite good enough for one who has worn her Britannic Majesty's livery. This attitude is the master-key which unlocks the hearts of the fair. Some of the gilded girls are sensible that a plain citizen who cannot 


\section{80 Life and Sport on the Pacific Slope}

ride to hounds or shoot driven grouse, who bears no crest and wears no livery, is unworthy of them; accordingly, when they meet a man who in his turn mounts the pedestal, they look up to worship, instead of looking down to despise.

The Moral Idiot is sent abroad because England is too right and tight a place for him. In the West he finds a climate and a people more adapted to his idiosyncracies. If you wish to play the dog in England, well-meaning friends insist on the muzzle and the chain. In the West you can run riot.

I remember a man who charmed the good and bad of his acquaintance by his geniality and fine presence. He was the son of an officer in a crack regiment, and although he had failed to pass into Sandhurst, he had taken high honours as a bachelor of those arts which please everybody except perhaps the Army Examiners. This one raced down the slopes of Avernus! He was so big and so powerful that those of his fellow-countrymen who tried to stop him were simply knocked head over heels, or else were constrained to follow him. But we hoped that he would pull up before he reached the bottom, because he was so cheery, so generous, so plucky, and because - strongest argument of all - he had such nice people, whose very photographs - so to speak - were letters of credit. Now the photographs of, let us say the Family Fool's nearest and dearest are generally kept under lock and key. Poor Johnnie, with all his stupidity and simplicity, is dimly aware that he cannot digest his husks beneath the reproachful eyes of those fond angels, his mother and sisters; so he lays their portraits, 


\section{The Englishman in the West 18 I}

face downwards, at the bottom of his portmanteau, where he cannot see them, nor they him. But our Moral Idiot was afflicted with no such sentimental scruples. His photographs stood - blushing, so it seemed to me-upon the mantelpiece of his room, whence they witnessed many a shameful scene; and beside them were other pictures of other women (although one might ask Heaven if they were in truth of the same sex); and seeing this it was obvious that nothing would suffice to stop the runaway, that, morally speaking, he was dead. Not long after his body died also.

The Remittance Man is the curse of all new countries, although in a sense he is nobody's enemy but his own. The monthly dole he receives from home serves to keep his body, but it plays havoc with his soul. As a rule the remittance is squandered within three days; and then follows a period of incubation, perhaps of repentance, during which the poor fellow lies snug on his ranch, or in his squalid room, if his tastes be urban. The homes (?) of the remittance men are curiously alike; an epitome, in fact, of the men themselves. If the remittance man be still young, a ranchero of three years' standing, you will note in and around his cabin the half-effaced signs of labour; a garden full of weeds, a cypress fence untrimmed, white-washed outbuildings now stained and discoloured, but once as clean and bright as the steel bits and stirrups which our friend brought from home. If you are of a curious turn of mind, the dust-heap at the back is worth exploring. The upper strata reveal a sorry collection of tomatoes and sardine cans; 


\section{82 Life and Sport on the Pacific Slope}

but stir the heap to its depths and you will find terrines and glass jars; the empty flesh-pots of Egypt, - relics of those happy days when Jim many remittance men are called Jim, - had hope in his heart and cash at his bankers. In this heap, too, are many bottles: from the aristocratic flask of maraschino to the plebeian pint of stout. Jim will inform you with honest pride that he knows how to do himself well. Inside his house, a three room board-and-batten shanty, is a dismal collection of household effects, and if you are easily shocked, it would be prudent not to enter the kitchen. For Jim never washes up unless he is expecting company, and you have caught him napping, for he is never so happy as when asleep. $\mathrm{He}$ will be sure to ask you to have a drink out of the demijohn that stands in the corner of the sitting-room, and, warmed by whisky, he may relate some of his misadventures. He planted out an orchard of Bartlett pears, but the jack-rabbits barked and destroyed his trees; he then planted alfalfa, which the gophers ate; then he bought some Jersey cows, and that year his pasture was accidentally fired and all the feed burnt up. You will note that Jim, and the gentlemen like Jim, generally begin with some enterprise that exacts special knowledge (which they don't possess), patience, and hard work. They try to run before they can crawl. It is a kindness to turn the talk into the domain of sport, for Jim cleans his gun, if he cleans nothing else, and he generally owns a handy dog who lies at his master's feet and is the best company that Jim keeps. Jim's eye 


\section{The Englishman in the West 183}

brightens as he speaks of the quail and ducks, and he will tell you that he and a pal are thinking seriously of shooting for the market next winter, only he will add it is "a beastly grind shipping your birds in good condition." Most things are "a beastly grind" to Jim and his friends. They keep no cow, because a cow must be driven in from the pasture and milked twice a day. You will mark few hens about the barn, for Jim will tell you that, in a country where coyotes and coons are many, it is necessary to lock up your hens each night in a marauder-proof hen-house. And that, too, is a " beastly grind.". Poor Jim blushes through his tanned skin when he asks you to stop and take pot-luck with him. Presently he retires into the kitchen, and you are left alone in his sitting-room. Here you will be sure to mark a curious assortment of old clothes, boots, a few books, a hunting-crop, some English illustrated papers and magazines sent regularly to Jim by his kind sisters and aunts at home, and many pipes. Upon most of these articles lies the dust of the West: that fine sand which drifts invisibly into everything - even into the hearts of men like Jim. You feel, perhaps, that you would like to buy a broom, to sweep and garnish, but your labour would be wasted. Dust, the dun dust of life, settles thick upon the Remittance Man. And he - this is the pathetic part of it-does not care. $\mathrm{He}$ has sold the birthright of a gentleman: the right to be well-groomed in body and mind, for a - remittance.

While you sit dreaming by the hearth, Jim has found a few eggs, and cooked a meal that tastes 


\section{84 Life and Sport on the Pacific Slope}

better than it looks. He has made some tortillas (pancakes) and the stew is excellent. Jim has a huge pot into which he puts his game, some tomatoes, an onion or two, and a double handful of rice. It is needless to add that a remittance man has no garden of his own. His vegetables are given to him by his neighbours, humble hard-working folk to whom Jim is a sealed fountain of mystery. They cannot understand how it comes to pass that a "high-toned, highly-educated, English gentleman" is content - like the fat weed on Lethe's wharf to rot at ease, when, if he chose to exert mind and muscles, a life of honourable endeavour lies within his grasp. But then they know nothing of the vampire which sucks from Jim's veins the good red blood of every ambition. Let cruel charity fasten her fangs in their throats, and they too would shrivel into paupers and parasites. Take from Jim his dole, force him to work, and he may attain unto the full stature of a man.

As a rule remittance men live in a small colony of their own. Co-operation is no empty word to them; it spells a little polo, a little golf, billiards, cards, and so forth. Play with these fellows is the serious business of life, and yet they talk glibly enough of their work! What a queer smack the word has in their mouths!

I remember a trio, whom my brother and I (we were reading "Trilby") used to call - les trois Angliches. Arm in arm they would parade up and down a broad road that had no beginning and no end. It was not a quarter of a mile in length, but smooth and level as an ivory tablet. High cliffs, 


\section{The Englishman in the West 185}

almost but not quite inaccessible, lay to the north and south; to the east was a summer sea; to the north, running the length of the road, a number of gay booths flanked a huge hotel. You could not wish for a brighter, more mirthful, fresher scene than this road presents in the middle of July; for it is Pleasure's Rialto, where the weary workers of Southern California come for a too brief holiday. It is, in effect, all that is left of the lotos land. And here the busy bodies of the Pacific Slope find, what they so sorely need, rest and recreation. But we never saw the three remittance men strolling leisurely from booth to booth, turning and returning, inhaling and exhaling the essence of the place, inspecting its simple wares, tasting and savouring its cakes and ales, without reflecting that they were not visitors but prisoners in this pleasance: hugging their chains it is true, but none the less captives. Did they, I wonder, turn sometimes a wistful glance to the cliffs? Who can tell ? They had their share of brains; they had been educated at famous schools; they came of good stock. And not one of them was fit to black the boots of an honest ploughboy.

Perhaps the Sportsman is the best type of Englishman who comes to the East, always excepting those distinguished travellers - diplomats, officers of the Army and Navy, and the like - who merely flit through the country on their way to Australia and the Far East. He belongs to the upper and upper-middle classes; and as a rule has the tall, slender, wiry figure of the man inured to hardships, the man who can ride, or shoot, or fish, all day and 


\section{86 Life and Sport on the Pacific Slope}

every day, and be none the worse for it. These Nimrods acquire a knowledge of the West at first hand. They see many phases of life; they talk with rich and poor, with gentle and simple, with honest men and knaves. Living themselves the primal life for many months, facing boldly the perils of the wilderness, apprehending, as they must, the obstacles that confront the pioneer, they can and do assimilate the facts, - those facts so indigestible to the traveller who sees a new country through the windows of a Pullman drawing-room car. More, leaving the wilderness they approach civilisation by degrees, passing over the trackless forest, then the blazed trail, then the foot-path, the rude country road, the highway, and lastly the shining rails.

The Native Son can never quite understand why these thin, sun-scorched, silent men take all that concerns sport so very seriously; they wonder how such men, possessed of energy, patience, powers of endurance, can hold themselves aloof from the traffic of the world. And it takes an Englishman, and a lover of sport, to answer the question. To those to whom "the long results of time" are an inheritance, there comes a nostalgia for life under new and more stirring conditions. The war of great cities, the ignominies and indignities of the modern struggle for money, or fame, or bread, drive them into the silent lands, into the enchanting solitudes of mountain and forest. Let it be remembered that these men have enough money, and the striving for more may mean the robbing of another. From this point of view, their abstention becomes surely a 


\section{The Englishman in the West 187}

virtue. But the energies inherited from fathers who worked hard and to good purpose cannot be denied; and these energies sustain the explorer, the hunter, and the naturalist. What else would drive a man into the pestilential swamps of equatorial Africa, or into the boreal twilight of a sub-arctic forest? 
XI

\section{THE SIDE-SHOW}





\section{$\mathrm{XI}$}

\section{THE SIDE-SHOW}

7 HE side-show of a big three-ring circus, where 1 you may view at your ease and leisure the freaks, is to my mind more amusing than the show itself ; for nowadays the senses are stunned by the ordered confusion of a triple entertainment. In like manner the thoroughfares of modern life have become so crowded and noisy that one turns with a sigh of relief into the alleys and byways that run to and from them.

Americans, I believe, have a keener appreciation of what they call "the side-show" than we. Perhaps in a new country there are more side-shows, but I doubt it. I know of a cathedral town in the south of England where four great classes live cheek by jowl: the military, the Dean and Chapter and clergy, the masters and boys of a great public school, and the ordinary townsfolk. By those who like to bet on certainties, a sum might be wagered that here within the shadow of four ancient institutions could be found more side-shows than in any city of the West; only you would have to search for them patiently. In the West the side-show is on the side-walk! Take, for instance, the side-shows of religion: Theosophy, Spiritualism, Christian Science, and the like. In England these entertainments are - so to speak - not 


\section{92 Life and Sport on the Pacific Slope}

licensed by the Lord Chamberlain, but in America, and particularly in the West, you can dance the hula-hula upon the tables of stone, and none will interfere.

Since the exposure of Madame Blavatzky, Theosophists have split up into camps: those who still believe in the priestess of Isis, and those who don't. The priestess, it will be remembered, unveiled Isis ; then in her turn she was unveiled, and the veil of mystery that encompassed a most remarkable woman was rent in twain. Reading the evidence of fraud that was submitted, it would seem incredible that any sane person should still believe in Madame Blavatzky, but so it is. Theosophy, however, being esoteric in its teaching, appeals to the few; whereas Spiritualism appeals to the many, the many whoas the immortal Barnum observed - like to be humbugged. It is true, of course, that a counterfeit coin does not impeach the value of the gold piece, but the most ardent Spiritualist will not deny that the bad coins have had an enormous circulation. Much of the so-called phenomena of Spiritualism has been explained by science, a little still remains - inexplicable. But the men of science who have given the subject attention, assert that science will reveal what is now hidden and will do it without the assistance of spirits. The Homes and Slades and other wizards who fairly enchanted alike believers and sceptics have been proved charlatans; but the mediums who advertise in the newspapers - unselfish women, for the most part, who, remaining poor themselves (their fee is only a dollar), devote their lives to making others rich - increase 


\section{The Side-Show}

and multiply. To certain minds the psychic powers of the seventh daughter of a seventh daughter born with a caul are incontestable.

The number of mediums, clairvoyants, astrologers, and palmists in San Francisco alone is most significant. One cannot doubt that curiosity is the besetting sin of the mob, but beyond and above it lies the worship of the visible rather than the invisible. The mob does wish to put its fingers into the wounds, to see, to hear, and to feel. The curiosity that drives some sorrow-stricken soul to the "parlours" of an illiterate stranger to learn news, however small, of the one who has passed into the world unseen may be condemned, but it is at least human and intelligible. And if proof of immortality is to be vouchsafed us from one whom we would not deem fit to dine at our table, or even be included in the circle of our casual acquaintances, shall we refuse it on that account? Here is a question which each must answer for himself. In the West it would seem that in some wells not Truth is found, but carbonic acid gas. But the motives that drive the mob to the ladies I have mentioned are not always so ingenuous. Many seek them for the most sordid reasons: for advice in regard to investments and speculative enterprises, for love philtres, for, in effect, a special knowledge of the future which they, the seekers after an unknown god, may transmute into dollars and cents.

The Christian Scientists, however, are cutting the ground from beneath the feet of the Theosophists and Spiritualists. I have carefully read Mrs. Mary Eddy's book, "Health and Science," and was not 


\section{94 Life and Sport on the Pacific Slope}

surprised to find that the good and the tender and the true, which illumine so many of its pages, have been taken from the New Testament. Indeed one might say of "Health and Science" what was said by a wit of another book: "There is much that is new in it, and much that is true; only what is new is not true, and what is true is not new." Mrs. Eddy bottles the wine of Christ and sells it under her own label. The metaphysics in the book were made long ago in Germany. And the stories of the miracles would astonish all of us were we not familiar with what is going on at Lourdes, and Sainte Anne d'Auray, and a dozen other places. According to Mrs. Eddy and her school, matter is not; Berkeley also said there was no such thing as matter, and the wits retorted that in that case it did not matter what he said. I have met many Christian Scientists, and I have noted that matter is not when, and when only, there is nothing really serious the matter. If the child of a woman professing Christian Science happens to be bitten by a rattlesnake, you will find that she sends hot-foot for the nearest doctor, and the antidote he prescribes is administered promptly. There is a profane story about a man tormented by toothache; the sufferer was assured by a Christian Scientist (the name challenges a smile, because Christian Science is endorsed by neither orthodox Christians nor men of science) that he was the victim of his imagination, that if he would sit still and allow his mind to dwell upon the true substance of life, what has been wrongly termed the idealities, weening it from the trivial shadow, his throbbing molar, he would 


\section{The Side-Show}

infallibly become sane and whole. The sufferer was willing enough to try the experiment, and did sit silent and absorbed for nearly half an hour. At the end of that time the Christian Scientist asked sweetly how he felt. "I feel, Madam," he replied, "like a damn fool."

The men of the West owe much to Mrs. Eddy, for her teaching has wrought some wonderful cures amongst anæmic, hysterical, drug-poisoned women. A physician told me that Christian Science was a specific for nervous affections. He also told me that a colleague of his, an Agnostic, had been treating a Catholic patient for one of those obscure lesions to which female flesh is heir, and that, despite his efforts, the patient had steadily grown worse. But she was quite confident that if only she could visit Lourdes, her health would be miraculously restored. The doctor gravely and truthfully assured her that in his opinion holy water of Our Lady would wash away her infirmities; and, as it was impossible for the patient to undertake a journey overseas of some seven thousand miles, he begged her to send for some of the water, which the lady did; and, having absolute faith in the elixir, recovered her health and strength!

It is curious to mark in a new country that men run after strange gods as soon as they forsake the faith that sustained their fathers, but we are concerned now not with ethics but side-shows. Perhaps the side-show is more amusing when one individual occupies the stage. This was emphatically the case with Richard Hobson, the hero of the Merrimac, better known perhaps as the Hero 


\section{Life and Sport on the Pacific Slope}

of the Merry Smack. After his achievement he was turned into a side-show. As one of the newspapers put it: "The American women are trying to make a star-spangled ass out of our national hero;" and the women came perilously near to doing so. The hero was kissed into exile, it was said; and at one place more than two hundred and fifty fair adorers stood in line, and patiently and rapturously awaited their turn to be embraced. Lieutenant Hobson accepted this homage with an humble and grateful heart; but one hardly likes to think what would happen if similar sweet courtesies were offered to Admiral Dewey or to Sir Redvers Buller.

Hobson, willy-nilly, was made a side-show; Joaquin Miller, the poet of the Sierras, made himself one: surely a greater offence. It will hardly be believed in England that this man, who has written some of the finest poetry in the English language, should join a variety show and exhibit himself nightly, in costume, to all comers. One would as soon expect to see an archbishop dancing the hornpipe in Ratcliff Highway.

There are many side-shows. The word is often used to express an isolated sense of the ridiculous. A person in our county was preaching on behalf of Total Abstinence. To clinch his argument, he cited the case of his own father who had destroyed a vineyard in full bearing rather than make wine of the grapes. We were profoundly affected by this, and felt that it was a privilege to sit at the feet of such a man's son. Some weeks later, this parson was in the office of a friend of mine, and the 
talk turned upon Californian wines. "As a matter of fact," said the parson, "most of the vineyards now in full bearing don't pay, because the wrong varieties were planted out. My poor father made that mistake, and he was forced to root up every vine." My friend told me this story (he had heard, of course, the sermon), and I asked him if he had allowed the parson to escape without a word of protest. "If I had let him know that I heard his sermon I should have spoiled the side-show. Now whenever we meet I shall have it all to myself."

I remember another story, told to me by a gambler. A gambler in the West is higher by a few rungs of the social ladder than the whitecoated gentleman who dispenses drinks across a bar. I gleaned this important fact from a bartender many years ago. I had asked if a certain friend of his tended bar. "What!" he exclaimed, "tend bar? Not on your life. He plays - keerds." My gambler was a character, as indeed are most of these knights of the green cloth; and he was not averse to relating - to sympathetic ears - his adventures by land and sea. He had heard, it seems, that a notorious poker-player had taken passage upon a certain steamer, where high play was not forbidden (as it is to-day on nearly all steamship lines). Billy (my friend) wishing to shiver a lance with this champion also booked his passage, and so in due time Greek met Greek. "Of course," said Billy, in telling the story, "I played 'possum, and Mister Man had n't a notion that I knew the very first thing about poker; but he did know that I had about four thousand dollars in my inside pocket 


\section{Life and Sport on the Pacific Slope}

and I saw, by the fire in his eye, that he meant in due time to annex 'em. We played several games before he went to work; and he allowed me to win most of his small change. Well, sir, about the fourth day, after dinner, he asked me to share a bottle o" wine" (champagne) "with him; and after that he said he felt like a little game, and I told him that I was with him, and that I'd never felt more like a winner - which was so. Four of us sat down, and we fooled away about two hours. During that time I had collected the six, seven, eight, nine, and ten of diamonds. I took no face cards, for I knew he'd miss them in his shuffle. Presently he dealt me three Jacks, and in the draw he got the fourth. He could play poker, that feller, for although I was watching him close I could n't see any monkey business. Pretty soon only him and me was left in, and the pot was a big one. 'You 'd better quit,' said he, pleasantly, 'my hand is a corker. I know how to deal, my boy, and it will cost you one thousand dollars to gaze on my hand.' He was quite the gentleman, and I played up to him. 'You are not a good dealer,' said I, - for you've given me a better hand than yours; so although I hate to take a friend's money, still as you insist, I'll see that thousand and go two thousand better.' Two minutes after there was eight thousand in the pot and we showed down. He had four aces, and when I spread out my flush sequence you'd ought to have seen his jaw drop. $\mathrm{He}$ took his medicine without a whimper, but Great Scott! - that face of his was a - side-show!"

It is a side-show when a man says something 
humourous, being himself unconscious that he is affording amusement to others. One day a man came into our office, and observed in the course of conversation that he was about to take a little holiday: "My brother-in-law," he added, "is a mighty sick man, and the doctors are going to operate on him. It will kill the poor fellow sure." $\mathrm{My}$ brother, to whom he was speaking, looked sympathetic, but the man seemed to enjoy discussing details. In conclusion he casually observed: "Well, I'm not making this trip for pleasure only. I hope to ring in a little business." The story would be funnier if one substituted mother-in-law for brother-in-law, but I have told the tale without embellishment.

Alphonse Daudet (I think) said that he had attended many amusing funerals, and doubtless he was alluding to the side-shows. In the West-as I have already "pointed out - the funeral has often the characteristics of the wake. I remember attending an imposing function which had been entrusted to the Knight Templars, of which exalted order the departed had been a member in good standing. The Sir Knights attended in full uniform, and the exercises - as they are called - took place in the double parlours of a large hotel. The relations and intimate friends of the dead man occupied the inner parlour; the rest of us sat in the outer. At a certain stage in the proceedings the officiating minister invited those of us who wished "to view the remains" to walk into the inner room: a detestable custom that still prevails in many parts of America. A pair of female ghouls 


\section{Life and Sport on the Pacific Slope}

promptly availed themselves of this gruesome opportunity, and while they were absent two ladies came in, and, seeing the vacant chairs, sat quietly down in them. Presently the ghouls returned, glaring at the intruders. Finally, one of them, giving indignation words, said in a loud whisper: "Madam - these are our chairs." Now chairs being at a premium, I wondered what would happen. The lady who was addressed looked up and smiled blandly: "Your chairs?" she repeated, sweetly. "Oh, dear, no! They belong to the hotel."

At another funeral of a county official I marked the extravagant grief of the widow, who with difficulty was restrained from flinging herself into the grave. Speaking of this afterwards to a friend, he said, rather brutally I thought: "That was side-show. I know that woman. She has made her plans already. She will marry again within six months." She married again in three months.

This appreciation of the side-show means much to the people who live in the West, particularly to those who live in the towns and cities. To the average man of business, as to Dr. Johnson, a green field is like any other green field; Brother Jonathan has no stomach for Nature's varied bills of fare; Bills Payable and Receivable engross his attention. But he studies mankind (not womankind) far more closely and to better practical purpose than John Bull, and the study brings with it its own reward. Curiously enough, he obeys the poet's rather than the philosopher's injunction. His knowledge of others, sound though it be, loses much of its value 
because study of himself, that intimate self-analysis which teaches a man his potentialities and limitations, has been neglected. In the West you see many men floundering in a quagmire of difficulties into which ignorance of their own powers has enticed them. An American overrates himself, whereas the Briton underrates others. An American, again, is truly thankful and grateful to those who furnish him with entertainment; the Englishman is slightly contemptuous. In England the cap and bells provoke a malicious laugh; in America a kindly smile; the Englishman is so morbidly afraid of making a fool of himself that he is often blind to the fact that others have performed that office for him; a son of the West begins by making a fool of himself, and thereafter considers himself entitled to make a fool of others.

In the West there is always "side-show" whenever sickness comes to a family. You may be sure that if the doctor has prescribed plain diet for a child prostrated by a bilious attack, some fond sister or aunt will appear at the bedside with a chicken fricassee, made with cream, or possibly a frothing cup of chocolate, or some other delicacy equally unsuitable, and the patient is allowed to swallow these rich foods because, if he did n't, the kind cooks would feel badly. 

XII

\section{POT-POURRI}





\section{XII \\ POT-POURRI}

T $\mathrm{N}$ the West all men, women, and children read 1 the daily papers - between the lines; but they want the lines exaggerated, particularly the headlines, which faithfully interpreted tell the busy man all that he cares to know. I shall never forget what was said of a certain governor of California at the time of the great strike at Sacramento. The militia had been called out, and everybody expected serious trouble. To some, civil war seemed impending ; traffic was suspended; business was at a standstill. During this crisis, the Chief Executive, for reasons which he has never given to the world, was lying safe and snug at his country place in the South, pursuing a policy of what may have seemed to him masterly inactivity. Commenting upon his absence, one of the big San Francisco dailies said in the editorial column: "Oh, what a tower of strength Governor M- has been to the State of California in the hour of her need!" That - and nothing more. The history of this strike is a concrete example of the contention that the Press reflects humourously public opinion, a mirror of invisible convexity which distorts things and persons seen therein. On the Pacific Slope generally the sympathy of the people hovered above the strikers. It appeared to them a case of the Man 


\section{Life and Sport on the Pacific Slope}

with the Dollar versus the Man with the Hoe. Mr. Eugene Debs, who posed for a brief season as the Napoleon of Labour, and his staff issued the most stirring manifestoes, and more than one thoughtful man believed that a certain prediction made by $\mathbf{M r}$. Herbert Spencer at a farewell dinner was about to come to pass. I cannot quote Mr. Spencer, but he foresaw the vast opportunities which a democracy offers to the man who can play popular tunes upon public opinion. Mr. Debs twanged his harp, and America listened - and was profoundly affected. In my county, it was hardly safe to criticise the music or the musician. Later, writing of another man, Mr. Ambrose Bierce remarked:

\section{" He fiddled his fiddle-did-dee} Till the bows and the strings Were invisible things ;

And a vibrant blur was he."

To the people with whom I came in contact, people lacking even an elementary knowledge of the principles of political economy, Mr. Debs was a vibrant blur upon the landscape. What had heretofore been clear to them - their own property rights, for instance-became suddenly obscured. And this obscurity reflected by the Press became a pea-soup fog, a Cimmerian darkness. Fogs, however, even London fogs, eventually lift. A brisk breeze from the lungs of the people cleared our skies. And why? Because some ill-advised wretches derailed a train. No matter how thick a fog may be, if you chance to stumble over a dead body you will know it. The people of California stumbled blindly 


\section{Pot-Pourri}

upon a corpse, and, lo! the scales fell from their eyes. In a jiffy it was quite obvious to the meanest understanding that innocent blood had been wantonly spilled, that a shameful and brutal deed had been done beneath the flag and in the name of Labour. Coincident with this 1,400 cars of California fruit were side-tracked in Chicago, and the fruit spoiled! Instantly the common-sense of the public asserted itself. As quickly the Press recorded the fact. Of the mob of gentlemen who write with ease what they are told to write hardly one was left to champion the cause of the strikers, and soon after Mr. Debs was clapped into jail, and we heard no more of him. It was the sense of the West that he had not only fiddled but fuddled away a great political opportunity.

There are some people West of the Rocky Mountains who take the Press seriously. One gentleman I know fathered a bill which provided for the justifiable slaughters of editors by those whom they had lampooned. No doubt the gentleman in question had suffered much and often, but being a public man he ought to have known that you cannot kill an editor with a bullet; you are far more likely to kill yourself. The Press received the bill with intense appreciation of its ludicrous aspect. One wit gravely contended that all newspaper men were fair game, but he demanded a close season - say one month in the spring - wherein the brethren of the pen might increase and multiply in peace! You can hoist such engineers with but one petard which they regard as peculiarly their own - ridicule. A story went the round of the newspapers 


\section{Life and Sport on the Pacific Slope}

about a poet who wrote some verses entitled: "Why do I live?" The editor to whom they were submitted returned them with these lines: "You ask the question - Why do I live? We will answer it. Because you sent your poem to us instead of bringing it."

The Western Press exasperates the travelling Briton, for things British are invariably caricatured. On the French stage milor is always presented with big protruding teeth and long, red whiskers, what were once known as Piccadilly weepers. Without these credentials, so to speak, he would not be accepted or recognised. In the West the people know nothing about England, and the Press faithfully records that ignorance.

With infinite regret I state as my profound conviction that the majority of persons living West of the Rocky Mountains rejoices when Britannia mourns. Salt it as you will (and as you must) abuse of England is greedily gobbled up. The demand creates the supply, a fact well understood by the editors of newspapers. The statement that a Boer, under the protection of the white flag, has treacherously shot an Englishman is branded as a lie by most Western journalists. The statement that Tommy Atkins has been guilty of a similar act of treachery is proclaimed as truth-despite the testimony of such witnesses as - let us say Mr. Julian Ralph, an American. A clipping lies before me as I write, in which the writer says that the Boers are twice as brave as the British soldiers. Yet the American correspondents in the field have all testified that the Boer dare not face the British 


\section{Pot-Pourri}

bayonet. An Englishman would make no insidious distinctions between Spanish and American valour; a Westerner wallows in odorous comparison, and the stronger the odour the more he likes it. The word "hireling" has been applied again and again to our soldiers most offensively. In a sense they are hirelings; so were Roosevelt's rough-riders, so are the Boers, and the soldiers of every nation on earth. The use of such adjectives plainly proves that the Western man in his heart wishes to insult and offend Englishmen.

It is time therefore that England understood that the vapourings of after-dinner orators upon the unity of the Anglo-Saxon race, upon blood being thicker than water, upon our kin beyond sea, and so forth, are so much smoke. The Americans are not Anglo-Saxon, but an amalgam of Teuton, Kelt, Latin, Slav, and Anglo-Saxon. We happen to speak a language somewhat similar to what passes current in the United States; we are also Uncle Sam's best customer and his biggest creditor; we have ideals in common; laws in common, Shakespeare and Milton in common; England and America have, in short, what has been called a "manifest destiny" to work (not together but apart) for that which makes for the enlightenment of the world and the progress of civilisation; but we are not brothers, nor cousins, nor good friends - and that is the naked truth. I am speaking of the Pacific Slope, although I am of opinion that in the East also the masses are hostile to England; and I have yet to meet an intelligent Englishman who has lived his life in the West who does not 


\section{Io Life and Sport on the Pacific Slope}

share my views on this unhappy subject. On the other hand, many of my friends in the West, and those connected with me by marriage, contend that no Englishman can possibly apprehend the spirit of the West, and that "things" - as Truthful James would say - "are not what they seem": that deep down in the Western heart are respect and esteem for the British nation. In reply I submit that this sentiment of affection is so deep down that, so far as I am concerned, it is absolutely out of sight.

None the less my friends may be right when they assert that the majority does claim kin with us, for has not the inimitable Mr. Dooley remarked: "They annoy us so much that they must be mimbers of our own family."

In England the great newspapers direct and mould public opinion upon matters not to be apprehended without special study. In the West the busiest man must do his own thinking. He might borrow the opinions of others, but this, as a rule, he is loath to do. Professor Hopkins, speaking of the Transvaal war, says: "I hold no brief for England, but while she serves God and man I rejoice in her triumphs. For God is served when Man is bettered. This was the case in India. It is true of Egypt. It is true of the many little lands she holds around the earth. It will be proved again in South Africa when Boer authority yields to the higher civilisation." Captain Mahan says of the Boers: "Their right to administer the country as they please depends upon the use they make or have made of that power. Personally I believe they " (the Boers) 


\section{Pot-Pourri}

" have greatly failed and have forfeited that right. I believe the Boer Government and general administration to constitute a corrupt and oppressive oligarchy. Is it possible that there are Americans who in face of the records really believe that the Transvaal rather than Great Britain stands for the cause of political liberty and purity of administration?"

Captain Mahan may well ask such a question. And the answer to it ought to stimulate the sense of justice and fair play upon the part of his fellowcountrymen. The majority of Americans do believe that the Transvaal stands. for the cause of political liberty. And they would sooner listen to the impassioned rhetoric of a Parkhurst than the wellweighed utterances of a Mahan, an Alger, or a Hopkins.

None the less, thoughtful Americans with whom I have talked on this subject are of opinion that truth prevails in the end.

It is impossible in a book like this to defend the Imperial policy of England or to indict the American misconception of that policy, but I cannot forbear quoting a few lines clipped from an editorial which appeared in the "San Francisco Chronicle" under date November 19, 1899 ; a fair sample of the food supplied by Western journalists :-

"The records of the Transvaal show that $a$ very moderate tax is imposed upon the net output of the gold mines of the Rand. ... To the Boer's credit it must be said that not one instance has been cited against him of maladministration of justice to the stranger who has invaded his country." 


\section{I 2 Life and Sport on the Pacific Slope}

\section{Not one instance!}

The man who wrote this leader was wilfully perverting the facts in obedience to the dictates of the Man in the Street.

Do the people who read such stuff know that the Transvaal Government threw into prison British subjects who refused to bear arms against the Zulus? Do they know that the property of British subjects was confiscated without trial? Do they know that the very moderate tax (indirect as well as direct) imposed upon the gold miners of the Rand brought them to beggary and starvation? Let those who doubt the unparalleled corruption and oppression of the Boers read such books as "The Transvaal from Within," "Side Lights on South Africa," or the Blue Books.

I will cite one more instance of deliberate misrepresentation upon the part of the American Press. When famine and plague were ravaging India in 1897, Mr. Julian Hawthorne was sent by the "Cosmopolitan Magazine" to report at length upon the condition of the natives and the efforts made by the British Government to ameliorate their unhappy lot. Mr. Julian Hawthorne - as all the world knows - is the famous son of a more famous father, and no better choice could have been made. To such a man public and private doors alike were flung wide open. He saw and described the horrors of starvation and disease, and what he wrote was widely read and as widely discussed. My numbers of the "Cosmopolitan Magazine" which contain his report are tossing about somewhere between Hampshire and Cape Horn, so I cannot quote Mr. Haw- 


\section{Pot-Pourri}

thorne verbatim, but he testified in no meagre words to the Herculean task successfully undertaken by Her Majesty's Government; and he said flatly that no other Government could have done as much, confronted as it was on all sides by prejudice, fanaticism, and the most heart-breaking ignorance of the laws of hygiene. And yet in this same magazine appeared an editorial comment, indicting in scathing language the very methods so handsomely commended by Mr. Hawthorne, and these editorial comments were copied by the Western Press. No honest man, reading them, could doubt that Mr. Hawthorne had found in India British indifference, intolerance, and inefficiency. To those too busy to read the articles of the special correspondent, these excerpts represented the facts.

I have said in a previous chapter that the tide of prejudice against English methods and institutions will turn when English and Americans fight under a common flag. That day may be nearer than some think. It is an open secret that the German Emperor has cast covetous eyes upon the Brazils. Germany, not England, will challenge that famous Monroe Doctrine which has been flaunted so often, and so unnecessarily, in the faces of English statemen. And when that day dawns the United States will appeal - and not in vain - to her kinsmen overseas.

It is significant that the Anglophobia which discolours the judgment of so many Americans has failed to inspire a similar sentiment upon this side of the Atlantic, The people of England grudge America none of her triumphs. The Stars and 


\section{I 4 Life and Sport on the Pacific Slope}

Stripes provoke the most enthusiastic cheers whenever they are unfurled. According to the Western Press, this is cupboard love. John Bull is portrayed as Iscariot betraying Brother Jonathan with a kiss. But let it be noted that I am not speaking of English statesmen who may or may not have an axe to grind. I am speaking of the masses, who do not care a rush about politics, but who do honestly profess a kindly affection for a great nation speaking a common tongue. ${ }^{1}$

In conclusion I wish to say on behalf of the Western Press that it is only partly responsible for a condition of affairs which may be illumined by light from within rather than from without. Newspapers are printed to make money; and that

1 Many Englishmen are distressed at the difference between our tongue and the lingua Americana. Uncle Sam cuts the " $n$ " out of favour. Why does he add an " $e$ " to whisky? Is it not better straight? Again, in America latinised words are pronounced (very properly) in accordance with the continental pronunciation of Latin. Westerners say "tonsileetis," not tonsilitis. Why then do they pronounce the word we call quineen - quinine? Such "cussedness" baffles the philologist. The vowels we shorten are broadened in the West, and vicê versâ. The native son lends a richness to the " $\mathrm{o}$ " in coffee seldom found in the drink. A cowboy grins and jeers if you pronounce "calf" according to the rule laid down in the Century Dictionary.

The use of the letter " $r$ " jars upon ears proof against twang and drawl; for twang and drawl are in a sense distiuctive of the nation, although they may annoy a sensitive British ear at first; but the burr of the " $r$ " (in such words as dinner - dear - your Arthur) is the peculiar heritage of the lower class in England. A lady of quality may speak through her nose; a sprig of nobility drawls his vowels; but you never hear the plebeian " $r$ " in an English drawing-room except from the mouth of a servant, or from a guest whose claims to recognition are other than those of birth. In fine, the " $r$ " is a gutter-bred consonant, and will remain anathema so long as distinctions of caste exist in England. 


\section{Pot-Pourri}

newspaper makes the most money which caters successfully to the greatest number of readers. The journalists of the West are neither ignorant nor prejudiced. But they are free lances fighting, and fighting hard, for little more than bread and butter. Their taskmasters instruct them to weave ropes out of sand, to make bricks without straw. One man, a man of letters too, told me that he had instructions from his boss to embellish fifteen out of the sixteen pages of his "newspaper with either a murder or a suicide. The sixteenth, the editorial page, was kept immaculate, because - so said my friend-it was never read! Bits of description a visit to a children's hospital, the departure of a troopship, a presidential election - are done delightfully, charmingly, with a gift of vivid expression, an informing joyous humanity, a sparkle and sympathy seldom found in the columns of the great London dailies. But "no talent," to quote George Lewes, "can be supremely effective, unless it act in close alliance with certain moral qualities." The Western Press is profoundly immoral, because it deliberately throws a glamour of attraction upon vice and crime. I could cite a score of instances, but one will suffice. For many months two trainrobbers, Evans and Sontag, set the police of California at defiance. These men were brutes, endowed with the redeeming qualities of the wild beast courage and endurance. Upon these qualities the Californian Press pounced. Day after day columns of brilliant description were devoted to the adventures, the hairbreadth escapes, the thrilling experiences of two desperadoes. One enterprising 


\section{Life and Sport on the Pacific Slope}

journalist - at the peril of his life - actually sought them out, and his account of that interview, an admirable piece of work, was read with breathless interest by every man, woman, and child on the Pacific Slope. So cunningly, so artistically, so diabolically (in a sense) were the virtues of these ruffians set forth, that their vices melted from the public sight. Sober citizens observed to the writer: "After all, - such fellows deserve to escape."

The venality of the Western Press does not make for immorality, because (like a drunkard reeling through the streets) it is seen, and serves as a warning. More, the Press is not nearly so venal as the Man in the Street believes it to be. I have often been asked ápropos of a kind review of my novels: "What did that cost you?" Some papers are notoriously in the pay of certain corporations; and others - I speak from personal experience do not hesitate to demand blackmail from men with large interests at stake. And yet I am strongly of the opinion that the people themselves, not the proprietors of the newspapers, are chiefly to blame, and the remedy is so obvious as to need no mention here. Lest some English reader may be tempted to curl an "unco guid" lip, it may be well to add that the financial papers of the city of London are more venal and more unscrupulous than the papers of the West.

I have met many Western journalists and am greatly indebted to them for much kindness and courtesy. For the most part they are Bohemians, of a type that is passing away in London. With some it is always either a feast or a famine; after a successful "scoop" the wine flows freely, and you 
meet them in the smart restaurants or in the clubs, ordering the best of everything for themselves and their friends. When the dun days come they lie low, and drink "steam" beer and eat the humble sausage - " bag o' mystery," as it is called in London. Rain or shine they are full of "grit" and humour and charity. I must mention one in particular, a prince of good fellows, the late Dan O'Connell, a nephew of the famous Irishman, and like him in many respects. I remember a day's shooting I had with him many years ago. We shot nothing - for there was nothing to shoot; but we carried with us good store of what Dugald Dalgetty called "provaunt"; and we had a glorious time, supplied by Dan, who was truly inexhaustible.

To the Western journalist the world is an oyster, which he hopes to open with his quill; it behoves him therefore to keep that quill in some toughening mixture such as printer's ink. Not long ago I was walking with my father-in-law in San José, a pretty town in California known as the Garden City. Rounding a corner, we came upon a fellow talking to three small boys and an old woman. We halted and listened to a most amazing jargon, something quite inarticulate and incoherent. As we moved on, my father-in-law said that the man was "practising." $\mathrm{He}$ was learning, in fine, his trade. One feels sorry for the three small boys and the old woman, but seemingly they had no objection to play the part of strop. I once asked a lady-barber how she learned her art. If you come to think of it the question bristles like the beard of a buccaneer. What man is brave enough 


\section{I 8 Life and Sport on the Pacific Slope}

to submit his cheek to the virgin blade of a ladybarber? Not I assuredly. She answered quite composedly: "Oh, I practised on my husbandhe did n't mind." And the public "does n't mind" the practising of the journalist, not even when the pen pricks or stabs. It (the public) demands something stimulating, pungent, well-spiced, and if the pepper makes it sneeze, what of it?

But you cannot explain all this to the travelling Briton.

Politics in the West, even more than in the East, is a profession, a profession moreover that exacts undivided energies and which unfits a man for other callings. No citizen is so stupid and incapable as to be ineligible for state service as a candidate, but the people, as a general rule, are unwilling to entrust their interests to a gaolbird. I remember two men who were candidates for the office of District Attorney. One had served before, the other was a young man conducting his first campaign. The veteran was speaking in a small town, and after setting forth his own claims, he spoke as follows of his opponent: "My friends, I understand that Mr. X- is in every sense a worthy and honourable man, but I ask you to remember that he has never been tried - he has never been tried."

"That's so," exclaimed a voice. "You've been tried, old man, hav'n't you? And convicted too, by Golly!"

After due inquiry it appeared that the veteran had, indeed, been indicted for horse-stealing, and convicted. He was not elected. 


\section{Pot-Pourri}

A hayseed and shirtsleeve campaign is peculiar to the West. The candidate, born of poor but honest parents, makes up accordingly. For a season he shuns soap and water, leaves the hayseed in his hair, travels about in a ramshackle buggy, and thereby harvests most of the votes of his sockless brother man. One of these fellows was speaking at our county town. He held out a pair of singularly dirty hands, and assured us that he could wield the lariat better than he could the pen, that he was more at home in the corral than on the rostrum. Whereupon a sage sitting behind me observed with a inimitable drawl:

"Yes - he prefers the smell of manure to that of rosewater."

A seat in the State Legislature entitles the holder to write "Honourable" before his name. I knew one man who boasted that during his two years at Sacramento he had paid off a heavy mortgage on his ranch. He was not re-elected, but he remained "honourable" till he died. Such gentlemen begin their careers by attacking some wealthy corporation. They end as staunch supporters of the people they have assailed, for - as one of them once observed to me-political opinions are subject to modification. To the man "with the sack," Anglice, the millionaire, the word legislator is practically a synonym for blackmailer, although the majority of state senators and assembly-men would refuse scornfully a direct bribe. The Devil has many baits; witness the parson who rejected gold and preferment, but swallowed greedily a garter. 


\section{Life and Sport on the Pacific Slope}

And yet the practice of bribery is robbed of half its virulence, because it is done openly-coram publico. More, the present political system - the machine, as it is called - works fairly well, for the bosses and wire-pullers serve a fickle public, and are constrained, willy-nilly, to behave themselves. One of the best known bosses of California has never made a penny out of his politics. He loves power, of course, and he controls his "gang" with the unerring skill and instinct of a dictator, but outside of politics he is known and respected as an honest and honourable man. $\mathrm{He}$ will talk quite frankly about himself and his methods. "If I want a thing," he says, "I don't fool about with understrappers, but I go to headquarters and ask squarely the price to be paid. If I can pay that price-good. If not, I bear no ill-feeling, and I always try to give value received. I buy and sell political privileges in the open market."

Our methods in England are not so very dissimilar.

Not long ago an experiment was made, which failed. A young man of large wealth and good education presented himself as candidate for an important municipal office. In the clubs and in the streets it was confidently asserted that the "boss" had had his day. And it really seemed to be so. None doubted that the candidate was honestly anxious to inaugurate a new and happier system; that he was sacrificing himself and his interests on behalf of the state. A great many infamous jobs upon the part of the city supervisors had inflamed the public mind, and the can- 


\section{Pot-Pourri}

didate promised the people that if he were elected the "spoils system" should cease, that patronage should only be given where it was deserved, that the money-changers should be scourged from the city's temples, that, in fine, executive ability, economy, and integrity should succeed rapacity, improvidence, and depravity. He was elected. But notwithstanding his efforts, evil still prevailed and multiplied; the machine was fighting the man, and the man had only the moral support of his friends too busy with their own affairs to lend him a helping hand. The man had his raw and undisciplined levies, which the machine mowed down with golden shrapnel. I have not the figures, but I think it was abundantly proved that the City Treasury found vice less costly than virtue.

Optimists, however, predict a change. And it is certain that public opinion will demand a cleansing of the political stables. It is a question of time and money. Time in the West is money, and those who are destined to handle the brooms must be willing to sweep long and patiently. To-day, everywhere, there is an uneasy feeling that the politicians represent faithfully enough certain classes, and that it must always be so, so long as these classes flourish. Once a prizefighter was sent to Congress by a New England community, whereupon a wit said that the people had a right to be represented. In the West the "tough" element is slowly and surely disappearing, and with it will pass away the jobbery and corruption which taint practical politics. It is beginning to be under- 


\section{Life and Sport on the Pacific Slope}

stood that office-seekers, irrespective of party prejudice, must make good their claims to be elected. Civil service reform is tickling the ears of both Republicans and Democrats, and the Auditors, the Recorders, the Postmasters, and the like, are being chosen because they possess qualifications other than impudence and a capacity for absorbing unlimited whisky. I can well remember a contest between a Republican and a Democrat for one of the most important state offices, an office highly paid, but involving great financial responsibilities. The Democrat was a Catholic and in possession of the Irish vote; he was a man of great personal charm, widely known, and very popular. He was also a saloon-keeper, a gambler, and a profligate. The Republican, on the other hand, was unknown, but his record as man and politician was clean. The politicians predicted an overwhelming majority for the Democrat; but, by virtue of that change in public opinion of which I have spoken, the Republican was elected, and morality vindicated. I could cite a score of similar cases.

Public Opinion, in a new country, is a slippery customer, a chameleon whose exact colour varies from hour to hour, a lightning-change artist: yesterday, the apostle of the Monroe Doctrine; to-day, an ardent Imperialist; to-morrow, what? However, despite this Protean faculty (perhaps because of it), Public Opinion in the West, while it has tolerated and even cherished a certain absolutism verging on tyranny in regard to the conduct of Western affairs, has also been quick to profit by 


\section{Pot-Pourri}

the mistakes of those who live in the East. And the absolutism which for so many years sanctioned moral laxity and ignorance, has become now passive rather than active. Men still drink, but they no longer boast of being drunkards; the illiterate have no hang-dog air as in Europe, but they are quaintly sensible that silence becomes them better than speech; the loose-livers prefer the by-ways to the roaring thoroughfares. I remember a man who was always prating that he was self-made. A fellowcitizen with a sense of humour finally silenced him. "You are self-made; yes," he murmured, "and we may concede perhaps that you are as good as God's creatures, but are you any better?"

Public Opinion in the West serves one sauce to the gander and another to the goose. Outside of smart society, it is held to be a sin for a woman to play whist for small stakes, although Progressive Euchre parties for valuable prizes are customary and perfectly proper. In the hamlets and small towns kissing games are played with ardour by church members in good standing, but dancing is tabu. Certain expressions, common enough in England, are held to be improper west of the Rocky Mountains; if used at all they should be draped, which to my mind makes them indecent at once, even as a fig leaf makes the nudity of a statue conspicuous. Mr. Anthony Comstock, amongst other things, objected to the cupids so delightfully drawn upon the cover of Life; shortly after a famous cartoon appeared in that paper in which horses, dogs, and all animals were invested with pantalettes. In the West, the stranger and pilgrim 


\section{Life and Sport on the Pacific Slope}

will do well to remember that certain subjects must always be presented - in pantalettes.

I intended to devote a chapter to Western Art and Literature, but on both these fascinating subjects I am unwilling to speak. The reader will remember the story of the undergraduate who was asked to name the minor prophets: he refused, on the ground that he was not in the habit of making invidious distinctions. In writing of the authors and artists of the Pacific Slope, it is hardly possible to avoid invidious distinctions. From what samples we have already: such landscapes as Keith's, for instance, and such poetry as Joaquin Miller's and Miss Coolbrith's - we may confidently expect both in Art and Literature something sui generis. Something entirely different from what the East has given us. Much as I admire the subtlety and delicacy of Mr. James's and Mr. Howells's art, I am sensible that they deal with what is secondary rather than primal. The grandeur of the Pacific Slope is elemental, and the form in which that grandeur will find adequate expression will certainly not be a préciosité of diction. I remember Mr. Ambrose Bierce falling foul of the words "local colour," which, like other phrases, has become shopsoiled. But for lack of better words, these do convey definite meaning. The colour of Californian skies and seas and mountains and flowers is local. At least I have seen nothing like it elsewhere. The colour of that great Silent Land to the north of the Golden State is local. The adjective may be detestable, but we seem to have no other. And so we may predict that the picture, or poem, or 


\section{Pot-Pourri}

novel, which will represent the West as it is will be conceived and executed in a spirit absolutely original, differing in form, although not inferior in form, from what we have already. If style be "the stamp which makes thought current," the thinkers of the Pacific Slope must mould a die of their own. They cannot expect their message to the world to be franked by others. Improperly stamped, it must be sent to the Dead-Letter Office. 



\section{XIII}

\section{ETHICAL}




\section{XIII}

\section{ETHICAL}

T $\mathrm{N}$ a Western town or village the first thing likely 1 to catch the eye of the traveller (indeed it was invented for that purpose alone) is the sham front of his hotel. Upon examination he will mark that nearly all the stores and buildings are built to beguile the imagination. Even the livery-stables, board-and-batten barns, unpainted, roofed with shakes (not shingles), present a solid and fire-proof appearance when seen from the street; brick has been used possibly, or stone. And yet none is deceived : the thing is obviously sham, obviously built for show.

Is there not something pathetic in this? It is a sort of mild hypocrisy which, like a Scotch mist, pervades the atmosphere. The men who leave old countries for new must be profoundly conscious of the difference between the old and the new; they are for ever adjusting, so far as they can, this difference. Lacking the real thing, they try to console themselves with its counterfeit presentment. And the consciousness that despite their efforts the thing is a sham has a curious effect for good and evil. For good, inasmuch as each man recognises the false and wishes to substitute for it the true. Were he content with the adobe huts that satisfied the Hispano-Californians, were he willing to lie in 


\section{Life and Sport on the Pacific Slope}

the sun, to eat, to drink, and to dance, aimless and listless, the plaything of the present, he could not call himself American. He must struggle upward towards the ideal, be it attainable or not. The little girl plays with her doll, thinking innocently of the baby that may one day lie in her arms; the boy toots his penny trumpet, hearing the clarion note of the man. Who would rob these children of their illusions, who is not charmed and touched by their sweet monkey tricks? And yet what more pitiful than the sight of a grown woman or a strong man who has not learned to put away the toys that belong to youth alone. And so with the children of a new country, who cares to laugh at the sham fronts of the houses, knowing that these are card castles to be rebuilt of brick, and stone, and marble - by and bye?

The same spirit that makes men build false fronts to their houses, forces them to "keep up appearances" in everything else. They pay the price of lies - the word is too harsh, perhaps - by being constrained, as the poet tells us, to lie on still. Finally the lie masquerades as truth; the liar becomes convinced that he is an honest man. George IV. believed firmly that he had taken part in the battle of Waterloo. Once he appealed publicly to the Duke of Wellington, asking the great commander if it were not so. The Duke replied grimly: "I 've always heard your Majesty say so."

The writer has seen a country practically bankrupt, banks tottering, tradesmen unable to meet or collect their bills, farmers in despair; and this condition of affairs was not the effect of low prices, 


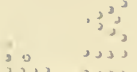

$$
\begin{aligned}
& \text { דבנד }
\end{aligned}
$$

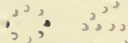

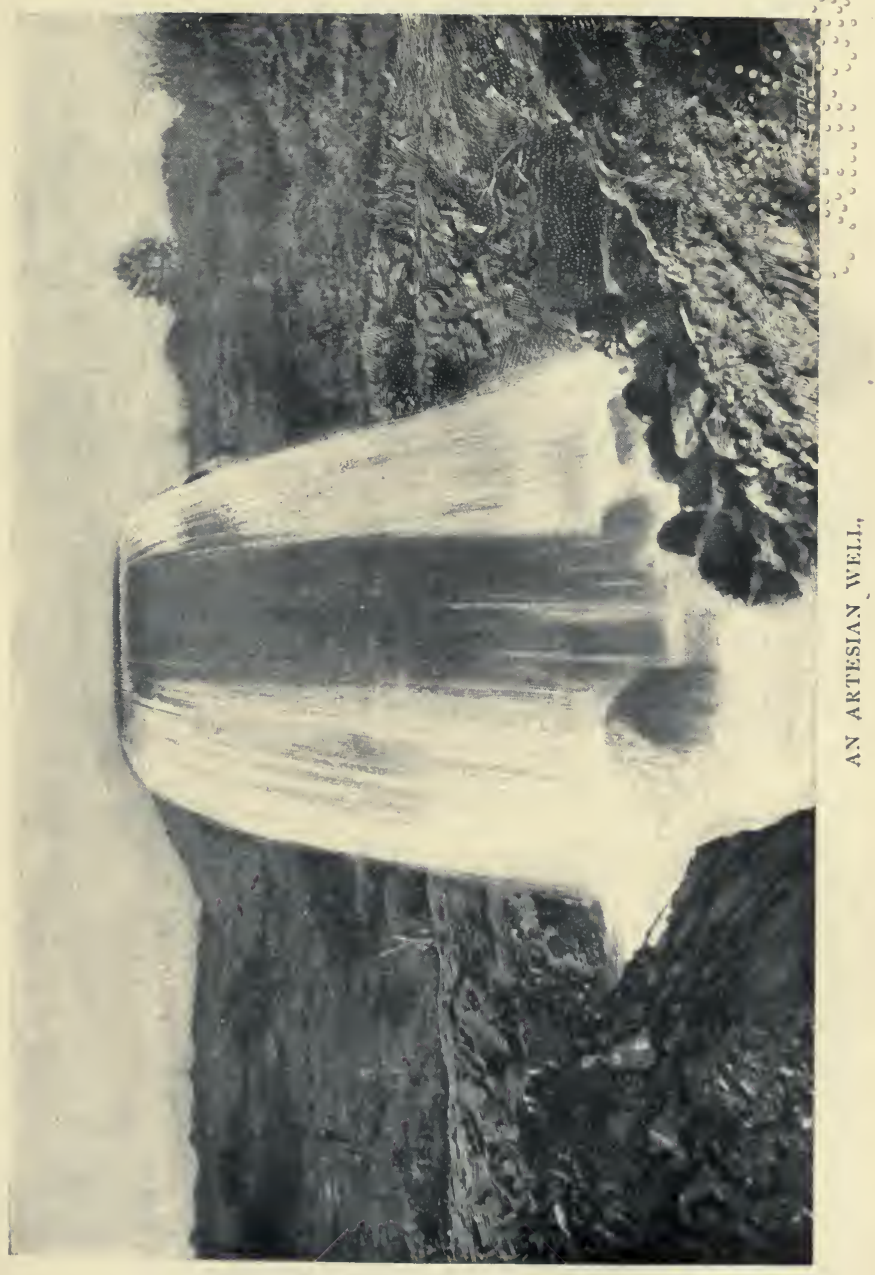



drought, and a collapsed boom, but the more subtle manifestation of doing business under false pretences.

It was then that the moral weakness of the community showed itself. The silver question was the topic of the hour. The leaders of the movement for what was called the "rehabilitation" of silver published pamphlets and small books by the million. These were easily read and digested. For many years the theories of the Silver men had attracted little attention. Now, of a sudden, these theories, in the mind of the crowd, became demonstrated truths. A French philosopher, Monsieur Gustave Le Bon, says that Napoleon was of opinion that the one figure in rhetoric of serious importance was repetition. The Silver men were sharp enough to grasp this truth. They kept on saying that if Uncle Sam passed a law making silver legal tender for all debts, at the ratio of sixteen ounces of silver to one of gold, their debts - and they were all in debt - would straightway be cut in half, silver at that time being worth as a commodity in the world's market about half the face value of the dollar. Men's minds were so inflamed, and their greed so quickened, that ordinary arguments were of no avail. The Gold "bugs," as they were called, tried to stem the tide with dignified remonstrance. "We can't have too much silver," said one street orator; "I never had too much silver - did you ?" Such talk passed current as wit and logic. I pointed out to a man that the debts of Uncle Sam to Europe were contracted on the understanding that they were to be paid in gold; that in obedience to a 


\section{Life and Sport on the Pacific Slope}

fundamental law, the cheaper metal would drive from the country the dearer; that America would be drained of its gold, and that these debts to foreign countries would be surely repudiated. My friend was in no way dismayed. "Look here," he said pleasantly, "that's an argument for and not against us. We ought to built a ring fence around the United States and then we'd cabbage these millions that you say belong to Europe."

Finally, the champions of gold were constrained to fight the Silverites with their own weapons. The country was flooded with more pamphlets mainly in answer to a man Harvey, the author of "Coin's Financial School." Other causes notably better crops and prices in the great midwest-combined to turn the trend of popular opinion. To-day, Silver, as a great political issue, may be pronounced - dead.

That Adversity taints men's sense of justice is a post hoc propter hoc argument. Not adversity, but ill-regulated prosperity preceding hard times really taints the people. I can remember the settling-up of the Arroyo Grande valley, one of the most fertile valleys in the world. When I first came to California it was a wilderness of weeds and willows - what the Spanish call "monte." When the "monte" was cleared, the soil proved peculiarly adapted to the growth of vegetables, and in particular the common white and brown bean. It soon became famous as having produced the largest onions in the world. Its pumpkins, too, and its carrots and beets were colossal. This valley belonged to a friend of mine, who sold it in small 


\section{Ethical}

subdivisions to the first settlers. They made a small cash payment, and gave their promissory note, secured by mortgage for the balance of the purchase money. In less than five years all these bean-raisers were rich. They built large houses, furnished them with Brussels carpets and oak furniture, bought their daughters pianos, clothed their women in silk and satin, and, in fine, spent lightly what they had lightly made. During the hard times of 1897 and 1898, I rode through this valley, and learned that nearly every farmer in it was bankrupt.

However, next time, when the wind of adversity blows keen and cold, their sails will be closely reefed.

English people, stay-at-home folks, condemn this extravagance and recklessness. But to me it is plain that nothing else could have reasonably been expected. Here is a country out of which, within the last forty years, have been taken tons and tons of gold, not to mention other precious metals. Its lands held at a few cents an acre have enhanced fabulously in value. Its products are found in every market in the world. And this enormous wealth fell, for the most part, into the hands of poor and obscure men.

I can remember a small experience of my own. There was a tract of land adjoining my ranch for which the owner asked some eight dollars an acre. It was similar in soil and so forth to my land; so I decided to buy it, and went to England for the money. In the frosty English atmosphere, my speculative instincts were nipped. Six months 


\section{Life and Sport on the Pacific Slope}

later I returned to California. The land had been sold to a friend of mine. And he had resold it, during those few months, for thirty dollars an acre!

To show how curiously the moral currency - to borrow Frederic Harrison's fine phrase - may be debased in a country subject to an amazing inflation and deflation of values, I will cite a remarkable case. The town of Santa Cruz sold some bonds in New York. These bonds had been placed in the hands of an agent who, after the sale, bolted with the cash. Thereupon Santa Cruz repudiated the sale. The Supreme Court, however, decided against the town, and made it honest. It is proper to add that this attempted rascality provoked emphatic condemnation from the State of California.

Nearly all the public buildings in the West are monuments of bad faith upon the part of the builder, contractor, architect, and those paid officials to whom the care of such important matters is assigned. The new City Hall in San Francisco is a pyramid of fraud incredible: the concrete example of a prodigious "job."

Speaking of public buildings, it has always seemed to me an incomprehensible blunder upon the part of a people who are shrewd beyond all others in adjusting means to ends that the designing and construction of school-houses, for instance, are entrusted to Tom, Dick and Harry, instead of to a Board of State Architects, specialists appointed for life, qualified to prepare suitable plans and see them honestly executed. Throughout Southern California, where the sun shines steadily for more than 


\section{Ethical}

three hundred days in the year, the school-houses lack awnings and broad verandahs. Economy forbids, you reply. Not so. Most of these gimcrack shanties are embellished with towers and cupolas. The instinct for display manifests itself in crude and vulgar decoration: friezes, panels, mouldings, what in short the people themselves call-frills. The moral effect of this upon the plastic minds of the children is not to be ignored. The girls learn to set an extravagant value upon appearance. Ask the druggists of the Pacific Slope how much money is spent by maidens not out of their teens upon complexion washes, arsenic wafers, hair dyes, beauty masks, bust developers, and - nose-machines !

In fine, the gentle art of pretending to be what you are not is ardently pursued in the West, although, like the will o' the wisp, it leads into quagmires.

The teachers in the schools and the pastors of the churches are not responsible for a condition of affairs which they strive (for the most part in vain) to ameliorate. Their efforts are handicapped by public opinion which assigns them a place too low in the social scale. In a new country, the interpreters of the spiritual lie beneath the heel of the material. Nearly all the ministers of the gospel are shockingly under-paid, and eating their bread and butter subject to the caprice of a committee of women. Above the head of the preacher impends a tempestuous petticoat.

The day must dawn when the men of the West will see the necessity of exalting the ministers of the gospel above the ignominies of work-a-day life. Now, they (the ministers) are constrained to beg, 


\section{Life and Sport on the Pacific Slope}

and borrow, aye, and steal the bread which should be theirs of right. I remember one man who went to a friend of mine to buy some timber. A poor, country parson, he had no ready money to pay for his timber, but he promised faithfully to pay within ninety days. More than a year elapsed and payment was not made. The parson had meantime been confronted by many trials and tribulations: his small stipend was not regularly paid; his wife and children were sickly; he was sensible that his influence over a scattered flock was languishing. The merchant called upon him. "I have come to tell you," said he, "that a preacher of the gospel ought not to promise what he cannot perform. It will pay you, sir, to be honest."

As if any man could walk upright with pebbles in his shoes!

In the West the churches are filled with women; the men are conspicuously absent. Talking with them on the subject, they say frankly that the entertainment provided is not to their liking. Divine service, without good music, fine singing, and an up-to-date sermon from an eloquent preacher, has no claims upon their consideration.

I often wonder what the children who are sent regularly to Sunday School and church think of the father who never accompanies them. They must indulge in some curious speculations, because there can be no quibbling, no double-shuffling concerning the issues involved. The children are solemnly warned that he who is not with the God of the Christians is against him ; and they are told again and again that public worship is an act of 


\section{Ethical}

allegiance, that a Christian goes to church to proclaim his loyalty and fealty, even as a soldier - no matter how well he knows his drill - attends parade. The men who say that they worship their Maker under the blue dome of Heaven are styled blue domers; but these gentlemen, I fancy, are not likely to shatter their health by a too zealous and protracted observance of their religious exercises. Many are professed Agnostics; but the Churches of the West have more to fear from the men who profess Christianity and do not practice it, who send their wives and children to church, while they remain at home, who talk glibly of duties and liabilities which they themselves ignore, than from the disciples of Huxley and Ingersoll, whose influence; like their teaching, is negative and passive.

And yet, religion - which has been so happily defined as a charter of happiness, not a bill of pains and penalties - is not dead but only sleeping in the souls of these men. The extraordinary sale of Sheldon's book, "In His Steps," proves this. Accordingly it would seem that Protestantism - for I am not speaking of the Church of Rome-lacks flexibility ; it does not adapt itself to the spiritual needs of the breadwinner.

But virile vigorous teaching can only come from the mouths of virile vigorous men; and few of these are unselfish enough to enter professions illpaid and ill-considered. The average American father does not wish his son to be a schoolmaster or a minister of the gospel; for, in his opinion, these gentlemen occupy a lower rather than a higher plane than the banker and merchant. 


\section{${ }_{23}^{8}$ Life and Sport on the Pacific Slope}

It is pleasant to testify that there are few Pharisees and hypocrites west of the Rocky Mountains. In this land of sunshine, men possess the virtue of transparency: their deeds, whether for good or evil, are not obscured. Let a drunkard reel through the streets, an object lesson to all, rather than lie whisky-sodden behind the bolted door of his own chamber! It is easy to know the men of the West. They talk freshly and frankly upon all subjects that are vital: religion, politics, love, hate, the topics which are carefully draped and masked elsewhere. But, subject to that instinct for display which impels some bankers to pile their counters high with big gold pieces, these wares of life, too garishly set forth, became shop-soiled and cheapened. When the Nevada Bank of San Francisco reopened its doors after a certain financial crisis, the gossips predicted an immense show of gold. They were disappointed; but the verdict of the Man in the Street was: "We know that they have it; why should they show it?" Millions lay in the vaults, the more potent to inspire confidence because unseen.

If snobbishness (as defined by the Century Dictionary) be a term applied to one who is servile in spirit or conduct towards those whom he considers his superiors, and correspondingly proud and insolent towards those whom he considers his inferiors, then the children of the West are not snobs. The pettiness and meanness which characterise the relations between the upper, middle, and lower classes of England are conspicuously absent. Class distinctions increase and multiply in California; but poor 
professional men - doctors, dentists, lawyers, dominies, and parsons - are not snubbed by their more prosperous fellow-citizens. Teachers and preachers - as I have pointed out in another chapter are underpaid; they are not treated as penniless curates and ushers in England - with supercilious indifference. Poverty, indicating physical or intellectual weakness, is pitied rather than despised. An example will make clear the difference between the two countries. An English gentlewoman of my acquaintance accepted a position as entertainer at a large spa. It was her duty to sing and play in the evening; but the manager assured her that if she were known to be upon the hotel staff, the snobs stopping under the same roof would treat her as a servant. The lady accepted the hint, passed as one of the guests, and was overwhelmed with gratitude and civility. In the West, the same lady would have received more attention by proclaiming herself to be a professional working for board and lodging.

And yet if Thackeray's definition of the word "snob" be accepted: "He who meanly admires mean things," the people of the West cannot escape criticism. Sharp practice, the meanest and most detestable of social crimes, is almost universally approved. Doubtless there is much sharp practice in England, but the sharpers do not brag of it. An English lawyer may fleece his client, a doctor may overcharge his patient; but these gentlemen do not publish to an admiring world the amount of the plunder. I know of one case (amongst many) where a "shyster" lawyer built a ten-thousand-pound 


\section{Life and Sport on the Pacific Slope}

house out of the fees received for the winding-up in less than a year of a dead man's estate. Strangers admiring the mansion are always told the story. One man remarked to me that the fellow was not really as smart as some supposed, because he might have taken more.

Other mean things unduly admired in the West are parades and processions with their dismal accessories of blaring bands, fire-crackers, penny whistles, and cheap oratory; self-assertion and self-advertisement, and an inordinate appetite for show. These, of course, are the small defects of great qualities; but it is doubtful whether they are regarded as defects at all by the Man in the Street. In common with us, too, the children of the West have a "lick-spittle" love of titles. Max O'Rell said that the United States contained sixty-five millions mostly colonels, but he said nothing about the colonels' wives. Mrs. Doctor Jones, Mrs. Judge Smith, Mrs. Major Robinson annex their husbands' titles with as little scruple as they assume his crest (if he has one) on their notepaper. There is a story of one eminent jurist who refused peremptorily to allow his wife to call herself Mrs. Judge XThis gentleman was given to the use, not the abuse, of cocktails, despite the protests of Mrs. Xwho was a pillar of some temperance organisation. It happened one night that his Honour returned home for the first time in his long life in a condition which he described afterwards as "mellow." His wife received him in silence, assisted him to bed, and waited patiently till the next morning. As the judge was finishing his second cup of tea, 


\section{Ethical}

she remarked acidulously: "Judge, after what occured last night, I shall for the future call myself Mrs. Judge X —." The husband shook his head. "Madam," he said, "I regret as much as you do that - er - the unforeseen came to pass last night; but it has not, I assure you, altered in any sense our relation to each other. I am still judge of the Supreme Court of California, and you, my dear, are only the same old fool you always have been."

In trying to understand the character of a people, it is necessary to find the master-key. What is it in the West? A worship of the visible? If the answer be in the affirmative, many doors are unlocked.

In England, the women, the very best of them, profess an ethical standard lower than it ought to be, because they wish to please the men. In the West, the men profess a higher standard (and profess it not the least hypocritically) because they wish to please the women - and children.

This wish to please - a delightful trait-has, when pushed beyond certain limits, a corroding effect upon character; it leads to the shirking of disagreeable duties, to a morbid fear of giving offence, to a tolerance of evil which soon becomes indifference; it ends by making pleasure - that form of pleasure which exacts continuous change and excitement - the supreme good.

According to Arnold, education is an atmosphere. If this be so, it is important that the air should be kept fresh and pure. Fresh it is in the West; is it pure? Let the parents answer that question. More, are they soberly of the opinion 


\section{Life and Sport on the Pacific Slope}

that the free-and-easy, go-as-you-please, what-'s-theodds-as-long-as-you-'re-jolly atmosphere of so many Western homes is free from baneful germs, the more deadly because invisible? The optimist contending that all's well with the world is a better fellow than the pessimist who maintains the contrary. Give me the joyous colours of hope, not the sable of despair, the shield of Ivanhoe, not the Disinherited Knight's. And yet the creed of that sneering host (enrolled beneath the banner of some fifth-rate De la Rochefoucauld) who holds that evil underlies all human conduct, that the good action is inspired by the bad motive, touches, as extremes always do touch, the vainglorious " $I$ believe in myself" of the rising generation.

Of political immorality, the wholesale bribing of legislatures, municipal corporations, debauching of the Press, - I use the words current in California, - something has been already said. When the secret history of California is given to the world, it will be admitted that such men as the late Senator Stanford, for instance, was absolutely forced either to fight the devil with his own weapons, or sacrifice the efforts and earnings of a lifetime. It is certainly not for Englishmen who know anything of their own political history to throw even the smallest pebble at such men. I hold no brief for expediency, but in the development of new countries it would seem that good does follow bad, and that a state may be compelled to take one step backward before taking half a dozen forward.

There is an almost universal desire to live intensely, rather than peacefully and comfortably. 


\section{Ethical}

The native son talks contemptuously of "rusting out;" he assures you that he proposes to wear out. I have never liked to tell him to his face that it is quite possible to rust out and wear out at one and the same time. I submit that a man is rusting when he avoids, whether of choice or necessity, the good company of books, pictures, and men wiser than himself; when he is blind to the freshness of fields wet with dew, to the glory of the skies; when he is deaf to the music of the woods. The mills of work-a-day life in the West grind exceeding slow, and the rust lies thick upon the men between the stones; but they do not know it, or knowing it, do not care. Juvenal's famous line will occur to some of my readers: Et propter vitam vivendi perdere causas. What is more pa-. thetic than the spectacle of a strong man who has gained his millions and lost his capacity for enjoying life? I can tell you. The spectacleso often seen in the West - of the man who has atrophied all the diviner qualities in the quest of wealth which he does not find.

Some of my readers will remember an anecdote of Bethel, afterwards Lord Westbury. He was famous as one of the most able and unscrupulous lawyers of his day. In one of his cases he had instructed his junior to call him promptly if the unforeseen presented itself. Shortly after the junior sent for him, and informed his chief that a certain judgment had been cited by opposing counsel which practically blew them out of the water; further argument, in the junior's opinion, would be wasted. Bethel rose to reply. He ad- 


\section{Life and Sport on the Pacific Slope}

mitted frankly that the judgment cited was incontestably adverse to his client's cause; and then, with his accustomed fluency and most impressive manner, he proceeded to show that this judgment had been reversed on appeal, and was therefore worthless. Opposing counsel was silenced. Bethel's case was won. Some weeks after the junior came to him in chambers. "Do you know," said he, "I cannot find any record of that judgment cited by $\mathrm{X}-$, nor of its reversal on appeal. Indeed I am inclined to believe that such a judgment was never given."

"Ah," murmured Bethel, in a voice indescribably bland and insinuating, "that is also my impression."

This story is not irrelevant, because in the West such smart practice is admired and imitated. The gain is obvious; the loss hard to compute. Those interested in such matters may examine the volumes of the California Reports which record the history of certain trials connected with land titles. To the student of ethics I would commend in particular the case of the Rancho de la Laguna de Merced, and the case of the Gabilan Rancho. In these, as in a hundred other somewhat similar cases, might drove right to the wall; but the end is not yet.

The late Mr. G. W. Steevens, in his amusing "Land of the Dollar," speaks of the Pacific Slope as "rapid." I cannot endorse the adjective. Mr. Steevens spent less than a week in San Francisco, and his own movements were so very "rapid" that, like a child in an express train, he may have 


\section{Ethical}

thought that he was standing still and that everything else was going to Jericho at the rate of sixty miles an hour. Fond mothers reading Mr. Steevens' prose would doubtless sooner send their sons to Jericho instead of San Francisco. And yet, humiliating as it may be to admit it, San Francisco is not in any sense more "rapid" than other big cities. Time was when she set a terrible pace; but to-day she "goes slow" in all things, as the merchants will testify. Los Angeles, lacking ninetenths of the advantages possessed by the metropolis, moves much faster. 



\section{XIV}

\section{BIG GAME SHOOTING}





\section{XIV}

\section{BIG GAME SHOOTING}

TF you want first class bear-shooting to-day, you 1 must go to British Columbia and Alaska. When we came to Southern California, two big grizzlies had just been shot not far from our cattle ranch; but we never had the luck to find one in our county, although we hunted diligently. One night, I remember, a huge fellow, judging by his tracks, passed within a few feet of where my brother and I were sleeping; but a grizzly travels fast and far, and owing to the thick brush we were unable to trail him next day. Dogs - small terriers - are almost indispensable, and these must be trained to their work. An old fellow in our county, where grizzlies were once extraordinarily plentiful, has told me many yarns, and, according to him, Ursus Horribilis is as easily killed as a big hog, if you can plant your first bullet in a vital spot. This man - he is still alive - used to shoot bear and deer for a living, and he shot more grizzlies than the famous Adams (whose book is still the delight of Californian boys.) More, he has the credit of a George Washington for unimpeachable veracity. According to this high authority, young grizzly bears often climb trees; but when they grow old and unwieldy they prefer the solid earth. Not far from our ranch house was a huge live-oak which 


\section{$25^{\circ}$ Life and Sport on the Pacific Slope}

served as a refuge for herders from the attacks of grizzlies. One poor fellow spent two sleepless nights in this tree, and on the following morning he threw up his job. His employer asked for reasons.

"You hired me," retorted the man, "to herd sheep; but I'm a liar if I ain't bin a herdin' grizzlies."

The vaqueros used to lasso them. Upon one of our shooting expeditions, I just missed seeing this done. Two men we knew, sighted a monster trotting slowly across a piece of level ground. They galloped up to him and roped him fore and aft; then one of the men slipped from his saddle and emptied his revolver into the bear's head. We examined the hide of this brute, the largest I have ever seen. The foreman of the ranch swore that he weighed eighteen hundred pounds; but this sounds incredible. We marked particularly the peculiar formation of the skull, the brow being set at an angle so acute as to turn any bullet unless it were fired from a balloon. For this reason old grizzly hunters will warn the tyro not to shoot at the head of a bear coming towards you. If you have the pluck to wait for him, he will stop and rear up; then let him have it in the chest. A side or flanking shot is the most certain.

My first experience with bear is worth recording. I was walking down a path, leading my horse, and looking for deer. Suddenly my horse snorted, and, lo! four silver-tips (a cross between the grizzly and the cinnamon) stood directly in my path. At the same moment the horse tore the bridle from my 


\section{Big Game Shooting}

hand and galloped back to camp. Meantime, the bears had not stirred, although the biggest of them was staring, disdainfully, straight into my eyes. I was idiot enough to drop onto one knee, and to fire pointblank into that grey grim face. The unearthly roar that followed shook the firmament. I can swear that I was cool till I pulled the trigger, but that hideous bellow, running the gamut of sound between rage and surprise, and culminating in a shrill scream of agony, undid me. The air seemed to be full of bears. In a jiffy I was up a tree, rifle in hand. It is my honest conviction that I pulled myself up to the first branch with one hand: a feat I have atternpted many times upon a horizontal bar, and never accomplished. Perched aloft, my wits returned to me. I looked down, peered through the leaves; the bears had vanished in the thick brush. Then I descended very cautiously, feeling no hero.

Next day, my cousin and I encountered these same bears, although the biggest was not with them (which proves that my aim had not been amiss); and we cornered and killed one of them. We wounded him badly, and he took refuge in a small patch of brush. Outside this we waited patiently, but in vain. Finally, I fired at random into the middle of the patch, and then out he came, determined to kill or be killed. What a fine fight he fought! I suppose we were a hundred yards or more from him when he waddled, growling, from the brush, and each time we hit him, he would stop and roar, biting and scratching at his wound. But he came steadily on, and he never stopped till my 


\section{Life and Sport on the Pacific Slope}

rifle was against his head! When we skinned him, we found that he had been shot through the heart, through the lungs, through the head, and through the loins!

Horses are terrified at the sight of bears, and I remember strapping the hide of this one to the pack-horse we had with us. Being somewhat cunning in such matters, we used the famous diamond hitch, and that horse bucked till I thought he would buck his own hide off as well as the bear's; but the hitch only tightened. Then he bolted, and we found him when we got back to camp, a sadder and wiser animal, peacefully grazing, with the bearskin still on his back.

The peculiar quality of a wounded bear's roar must be heard to be appreciated. We had a cook who one day met a bear, and fired at it. The bear roared; the cook fled. He came into camp (I was not there, but I can vouch for the truth of the story) screaming with fear; he entreated the "boys" to arm themselves; he swore that the biggest grizzly on earth was about to join the camp, et cetera. The camp listened, finger on trigger, but no bear appeared. Upon cross-examination the cook recited the facts: he had seen the bear under a tree; he had stalked it; he had drawn a good bead; he had fired. Then the bear had pursued him to within a few yards of the camp. Finally the boys set forth, and, lo! under the tree where he had been first seen was poor bruin - stone dead, with a bullet through his heart. However, the cook still maintains that the monster (he was only a small cinnamon) pursued him for more than a mile! 


\section{Big Game Shooting}

A bear-hunter I used to know well told me a story that sounds apocryphal, but which I firmly believe. He employed an Indian, who always accompanied him. One fine morning the pair sighted a large wapiti, which they shot and wounded. The Indian took the trail; but the hunter, knowing the habits of wounded deer, took a short cut across some hills, hoping to get another shot at the wapiti as it crossed a certain divide. $\mathrm{He}$ reached the divide and climbed a tree. Presently the wapiti came slowly up the steep slope; the Indian followed, knife in hand; and then, behind the Indian, not forty yards intervening, waddled a huge bear. So intent was the Indian upon his quarry that he was unaware that he, in his turn, was being tracked, till a bullet from the trapper's rifle whistled past his head and laid the bear low.

It is certainly imprudent to tackle grizzly, silvertip, or cinnamon bears on foot and alone, particulary in the brush thickets to which they nearly invariably retreat. Many a seasoned trapper has been killed or horribly mangled because he had the temerity to follow a wounded bear into the chaparral. Two men, side by side, can stop any bear; but beware the braggart who undertakes to show you bear and to help you kill them. I saw one of these fellows take to his heels at a critical moment, and he had previously boasted of slaying three grizzlies, single-handed, in one morning! Upon strength of this statement we engaged him as guide and protector. He never knew that we came within an ace of shooting him as he scuttled away.

It would be as well to particularly mention at 


\section{Life and Sport on the Pacific Slope}

this point the unwisdom of engaging scouts and guides on no recommendation save their own. The small towns that lie upon the outskirts of the big forests and prairies swarm with these gentlemen, and very few of them are worth a pinch of salt. Your honest trapper is in the woods, not lounging about a saloon or hotel, and it is only he who can show you first-rate sport, and he, remember, may always fail. Pay him well, and let it be plainly understood between you that he is not to shoot without orders. I remember one man - a very fine shot-who advertised in the local paper as follows: "John Doe undertakes to show gentlemen and sportsmen wild goats. Success certain. It is always your goat."

There are numbers of small black bear upon the Pacific Slope, but these afford tame sport. They are easily treed by dogs, and easily killed. In the woods and forests near the coast of northern California and Oregon, you are sure to find them if you are patient; but all bears, remember, are extraordinarily cunning and gifted with amazing powers of scent. I have been in skunk-cabbage swamps in Vancouver Island, where sign was plentiful, but bruin invisible; and once, in British Columbia, my brothers and I found a thicket where the tracks in and around the berry patches were innumerable; but not a bear did we shoot or see.

To-day, the best hunting ground is to be found upon the banks of the many rivers and streams which empty into the Northern Pacific. All bears love fish and berries, but, unfortunately (for the sportsman), at the time when the berries are ripe and the 


\section{Big Game Shooting}

salmon running up the streams, the fur of the bear is not at its best. The trappers like to shoot bruin when he comes out of his winter quarters. But his spring coat soon becomes shabby, and then you must wait till he grows fat again.

Reliable information can be obtained in either Victoria or Vancouver, and in the former town are several famous sportsmen who have shot everything that may be found in the forests of the North, from the rare musk-ox to the humble squirrel. But these gentlemen can hardly be expected to reveal the whereabouts of their own happy hunting-grounds. They will gladly tell you what to take in the way of impedimenta, and what not to take; and they will tell you also not to look for caribou and sheep in the places where these animals have been shot of recent years. If you can spare the time-and big game shooting is not to be undertaken in a hurry - it is wise to seek fresh ground, passing over the old en route to the new. Some parts of the country are more open than others, and after the first snows, the sheep and caribou are driven in search of food to ranges more accessible to the hunter. I believe October and November to be the best months for wapiti, caribou, sheep, and goats. The cold, it is true, is often intense; but there are no mosquitoes to drive you distracted, and the game is easily tracked. Many years ago, I spent the month of November in the North Park of Colorado, and although the mercury in my thermometer often fell below zero, and although our tent was as full of holes as a rabbit warren, we suffered not at all; and the sense of 


\section{Life and Sport on the Pacific Slope}

exhilaration, of physical vigour and vitality was delightful. At another time, my cousin and I were close to the Teton Basin, in Wyoming, whither we. had wandered in search of bison. We secured four fine bulls (almost the last that were shot), and awoke one morning to find the snow falling, and the possibility of spending Christmas in the wilderness staring us in the face. For several nights in succession we slept out without a tent, and were none the worse; but the tyro will do well not to stray far from civilisation when winter is impending.

I cannot advise the "tenderfoot" to hunt for wapiti in the woods. They may be found in the forests of Oregon and Washington, but only a seasoned hunter can stalk them successfully. The labour of cutting a path through dense woods is inconceivably trying to muscles and temper, and your impedimenta must be carried on your back, or on the back of your Indians. More, you may shoot-as a friend of mine did-some magnificent specimens, and be unable to carry home your trophies. Upon the Eastern side of the different mountain ranges that stretch from Mount Shasta to the Arctic circle, the foothills are, generally speaking, free from heavy timber. With a good field glass at your eye you can find your game, and approach it with the odds for, instead of against you.

Wapiti, the finest deer in the world, are rapid travellers, and soon driven from a country. It is expedient to make a rule not to fire a single shot when entering virgin country. I know how tempt- 


\section{Big Game Shooting}

ing it is to pot a grouse or a rabbit when there is nothing in the larder but "jerky" or bacon, but that one shot may drive a herd of these superb beasts to other pastures a hundred miles away! Once, I remember, we were constrained by our shikarri to leave our shot guns behind-a grave mistake. A month later we found ourselves on the borders of barren lands where there was no big game at all, and it seemed absurd to try and shoot small birds with Express rifles charged with one hundred and twenty grains of powder. So we borrowed from an old trapper we met an ancient flint lock, almost in pieces. The barrel of it was tied to the stock with string, and the flint would not strike sparks. We were actually compelled to fill the pan with powder and ignite it by means of a match. After stalking a sage hen, one of us would take aim; the other would strike the match ! Shooting under such circumstances is not an unalloyed joy.

Wapiti often betray their presence by whistling, a queer sound different to the call of a bull moose, and quite indescribable. The monarch of the herd, he whose enormous antlers thrill you to the marrow, generally trots along in the rear of the others, pausing now and again to look round. I once missed a monster point blank at forty yards, because I was fool enough to think that I could shoot him from the back of my horse. I had had an unpleasant experience with this same horse only a few days before, having dismounted in a hurry to take a snap shot at a running antelope. I missed the antelope, and nearly lost the horse, for he 


\section{$25^{8}$ Life and Sport on the Pacific Slope}

absolutely refused to let me come within twenty yards of him for more than four hot and exasperating hours. My cousin, who was with me, dismounted when I did, and his horse kept mine company. We were in an alkali desert at the time, and when eventually our animals suffered us to remount them, we swore solemnly that never again would we leave our horses untied. However, to return to my big wapiti: we had seen a large herd quietly grazing on the slopes of a bare hill, and recognising the futility of trying to stalk them, had sent a couple of men to drive them towards a divide in the mountains. We galloped to the same place, making a détour, and only arrived just in time. I took up a station some two hundred yards from my cousin, and marked with dismay the impossibility of tying my horse. Just then the herd began to ascend the slope at my feet, so without dismounting I hid behind a rock and awaited them. Long before I had seen through my glasses that the Nestor of them was unusually large, but I had formed no true conception of his truly immense size. I allowed all the others to pass, and presently he trotted by, very slowly, glancing now and again at the men half a mile behind him, apprehending no danger from my cousin and me who were invisible and to windward of him. I fired as he was broadside to me, and missed him clean with both barrels of my Express. Before I could reload, he had passed my cousin, who blazed away at longer range, and, being mounted, also missed him as cleanly as I did. We clapped spurs to our animals and had a tremendous gallop over a very stiff and 


\section{Big Game Shooting}

stony country, but we never got another shot at our quarry.

Talking of missing, I am reminded of another bitter experience that befell me many years ago near the Teton Basin in Wyoming. We had left our waggon, and taking a couple of pack-horses, made an excursion into a desolate country known as the "Bad Lands;" bad they were indeed: bleak and sterile hills rising out of alkali plains! But here we are told, and here only, the last of the bison might be found, and here we found them. We camped near a small spring whose waters were as those of Marah, and made an early start the next day. Before ten o'clock we were nearly dead with fatigue, and consumed by an intolerable thirst. The sun streamed down upon the glistening alkali and up again into our aching eyes; the ground upon which we trod seemed to emit a sickly and overpowering heat. At noon my cousin returned to camp, but I rode on, glass in hand, scanning eagerly hill after hill, seeking in vain that small black blot upon the brown landscape which would surely prove a bull bison. And at last, as I was beginning to despair, I saw two blots. Bison they proved, but how to stalk them successfully taxed imagination no less than experience. Finally I dismounted, tied my horse, and began a long and tedious stalk. I was compelled to crawl more than half a mile, lying face downward on the burning sand. As I crawled I was sensible for the first time in my life of the horrors of thirst, for my tongue began to swell; but I can swear that I was happy, for my ambition, so I thought, was about to be not satisfied 


\section{Life and Sport on the Pacific Slope}

but glutted. We had been assured by cattlemen and hunters, that the bison were almost extinct. To procure a specimen we had undertaken a long and dangerous journey into the heart of an unknown and sterile country. Now, not the prize, but the prizes, were within range. It never entered my head that a miss was possible, for as I crawled nearer, I saw that these were two immense bulls, big as barns, and seemingly quite unaware of my approach. They were lying down side by side. I crawled on till I came within eighty yards of them. Then I waited patiently till my heart stopped beating. Long before, I had endured the rigours of "buck fever," and I am sure that I was as cool as a man could be in such a place and beneath such a sun. But I missed them both! I made the mistake of firing at them as they lay. Had I whistled softly, they would have risen and stood still. I pulled trigger and saw the bullet strike the sand just beyond them. They scrambled up; and fearing they would run, I fired again with no result. Then they started towards me. In my haste I forgot to pull back the hammers of my Express. I wrenched it open, and rammed in a couple of cartridges. When I tried to close the breech, I realised, to my dismay, that the rifle was jammed. At the same moment the bulls saw me, and turned tail. I suppose they were six hundred yards distant before I got my rifle into working order, and then I pumped lead into the air till they were out of sight. After that I seriously considered the propriety of shooting myself. Life seemed worthless after such a misfortune. I told 


\section{Big Game Shooting}

myself that I should never have such a chance again. A truly wretched man rode into camp that afternoon.

Next day, I shot a splendid bull, and shortly after, another; but sportsmen will understand me when I say that life has never been quite the same since the irreparable loss of those two sleeping beauties!

Speaking of the "Bad Lands," les mauvaises terres, one is reminded of the "dry camps." A dry camp is a place where water is not. Nothing more forlorn can be conceived. After a long day's travel in sun and wind, you are obliged to pitch your tent where night overtakes you. The water you carry is hot and tainted, and the horses, poor beasts, snuff uneasily as you drink your thimbleful; well do they know that their thirst is not to be quenched. Then the question - an awful question - arises: "Shall we go on on the chance of finding some spring, or shall we go back?" Success or failure hangs upon a word; perhaps life or death! Uncertainty wrinkles the faces of even the dogs. The men in your pay are sure to be sulky and peevish. The wage paid to them seems, doubtless, inadequate. The master, on the other hand, finds the responsibility a grievous burden upon shoulders already stiff and aching. At such times fancy dwells upon the comforts of a club. Hungry, thirsty, dusty, and dirty, one asks one's self: "Is it worth while?"

Looking back, I find my memory tenacious of the good rather than the evil. I have endured many dry camps, but I cannot faithfully describe one; 


\section{Life and Sport on the Pacific Slope}

the outlines are blurred. When a man is fagged out of mind and body, sick at heart, as the old Latin primer had it, he takes no note of form or colour. Misery is grey and amorphous. On the other hand, the pleasant places grow greener as the years roll by. I can vividly recall a certain spot near a trout stream. Our larder was full of game : bear, venison, antelope meat, and small game. A deep, limpid pool invited us to bathe twice a day. The horses were up to their knees in bunch-grass. We slept beneath the pines, wooed to sleep by their plaintive sighs. We shot and fished and sketched; we ate and drank and slept; we were perfectly happy.

Not very far from this Paradise I had a narrow escape. My cousin and I were sleeping side by side. It chanced that during the previous day's ride we had seen a great many and killed a few rattlesnakes: a most exceptional experience. Suddenly my cousin woke up, and saw, by the light of the moon, a big rattler crawling across my chest. He lay for a moment fascinated, watching the sinuous curves of the reptile. Then he quietly reached for his six-shooter. But he could not see the beast's head, so he moved nearer, and, lo! 't was not a snake at all - only the black and yellow stripe of my blanket that gently rose and fell as I breathed. Had he fired, this book might never have been written, for he confessed to me that his hand shook.

Rattlesnakes have always inspired a certain terror in me, ever since I was struck by one. Fortunately I was wearing a porpoise-hide Field boot at the 


\section{Big Game Shooting}

time, into which the fangs entirely failed to penetrate; but I made - you may be sure - the record jump of my life. Some Californians have never seen one; but once seen or heard, Crotalus is not likely to be forgotten.

The sportsman in search of moose had better make up his mind to go to Alaska. He could not do better than stop en route at Tacoma, where Mr. W. F. Sheard, the taxidermist, will be able to give him valuable information in regard to the hiring of Indians, and so forth. I had a long talk with Mr. Sheard in the summer of '97, and looked over his collection of trophies, the finest (I believe) in the world. I have never had the good fortune to kill a moose; but Mr. Sheard told me that it could be done in the swamps and woods of the Yukon, although stalking in such places is very hard and disappointing work. Since I talked with Mr. Sheard, other localities may have been discovered, nearer to civilisation, but I much doubt it.

Caribou, the Barren-Ground Caribou (not the Reindeer proper), may be found in great numbers in certain parts of British Columbia. According to Mr. Warburton Pike, who has studied their habits, they annually migrate in huge herds to the barren grounds north of the Great Slave Lake. The woodland Caribou (Rangifer Caribou) is a larger beast; and they are still plentiful north of the Canadian Pacific line.

The Blacktail (Cervus Columbianus) is found from one end of the Pacific Slope to the other. They simply swarm in certain parts of the north, and the forests of Vancouver Island are full of them. 


\section{Life and Sport on the Pacific Slope}

In Southern California, in our own county, they were once equally plentiful; but the market hunters almost exterminated them in the early ' 80 's. Since then the laws for their protection have been enforced, and to-day they are increasing. ${ }^{1}$

The sportsman will find it hard to see them at first, for the grey of their coats melts at a short distance into the grey green of the chaparral. The best time to stalk them is at dawn in the dark of the moon, when they are feeding. After a cold night, you will always find them on the sunny sides of the cañons and gulches, and in the middle of the day they will lie in the thick brush near the crest of the hills. Some hunters wait for them at the deer licks, but this has always seemed to me a most tiresome and unsportsmanlike way of killing them. They ought to be stalked, and stalking in Southern California exacts much patience and skill. The breaking of a twig will drive them out of a cañon, and, once afoot, it is almost hopeless to follow them. On the other hand, when they are lying down in the chaparral, they will let you walk close up to them, scurrying away like a rabbit at the last moment.

1 Mr. Baillie-Grohman says that the blacktail (C. Columbianus) is the only deer found on the Pacific Slope. At the risk of differing with such a distinguished authority, I must submit that there is in Southern California a blacktail which would seem to be a cross between the Columbian and mule deer, not being so big as the mule-deer of the Rockies, nor so small as the deer found in Vancouver Island. Mr. Van Dyke (author of "The Still-hunter") and Judge Cotton speak of this deer as a variety of Macrotis. The mule-deer proper of Wyoming and Colorado is certainly not found in California. 
Antelope (the Prongbuck) were also plentiful in Southern California, and we have seen them on our ranch (and have shot them on the Carisa Plains beyond); but to-day they are very scarce on the Pacific Slope, and in California it is against the law to shoot them at all. I have shot a great many, and have watched large herds of them in Wyoming and Colorado. In California the vaqueros used to ride them down, an easy feat, if you have a horse that can both gallop and stay.

Antelope gave me my first attack of buck fever. I was in a country where the antelope were extraordinarily plentiful, but I could not manage to hit one. I could smash a small bottle at a hundred and fifty yards easily enough; an antelope at the same range laughed at my bullets. However, I persevered, and one morning killed a fine buck stone dead. After that my nerve came back.

Sheep and goat are considered hard stalking, but they are easily killed under certain conditions. Once, in the Selkirks, I shot six goats in as many minutes. I was above them, and when I fired, the herd ran straight at me. I could have clubbed one easily. It is well to mention that I had spent nearly ten hours in reaching my coign of vantage, an almost inaccessible peak. One of the goats fell two thousand feet after I had shot him; and I nearly followed him over the precipice, for the snow at my feet was crumbly and slippery, and a loose shale lay beneath. For the week preceding, my brothers and I had worn out shoe leather and 


\section{Life and Sport on the Pacific Slope}

patience without seeing a single goat. The month was November, and our camp thermometer fell each night below zero. The stalking, I remember, was uncommonly stiff, because the snow hid all mantraps, and again and again we tumbled ignominiously between trunks of fallen trees, or tobogganed down slopes, nilly-willy, - misadventures which look trivial enough on paper, but which discolour and distort the pleasures of big game shooting. Bad bruises mean sleepless nights, and sport without sleep ceases to be sport.

Many men think that hardships are part of the fun, but I am not of their opinion. Hardships, of course, must be endured cheerfully and patiently, but they need not be sought. For instance, it is folly to go into the wilds ill-equipped with food and bedding. $\mathrm{My}$ cousin and I were chaffed by the cowboys of Wyoming because our kit included rubber mattresses and rubber baths. These articles occupied little space, but how largely they added to our comfort!

One of the pains and penalties which wait upon a sportsman in the wilderness is being lost. Lost! What a word of ill omen! A word that in four letters embraces an encyclopædia. And the man who is cocksure of his bearings, who brags of his bump of locality, is, generally speaking, the first to go astray. Hills in a new country are amazingly alike. A familiar contour beckons you; a cañon invites you to enter; a stream prattles sweetly of banks higher up, where you have camped before. In the forest the trapper blazes his trail, but in the open foothills he must trust 


\section{Big Game Shooting}

to his compass and the landmarks; both often mislead.

I was lost once for three days in the company of a cook and a box of sardines. There was nothing to shoot, not even a sage-hen, and the sardines disappeared at the first meal. On this occasion I learned that a short cut is the longest way home. The cook and I endeavoured to cross a range of hills on the other side of which were our camp and supplies ; distant - so we estimated - less than twenty miles as the crow flies. We had an empty waggon with us, which we were forced to abandon (we retrieved it later), and we wandered round and round, compassless in an unknown sea of small hills and vales. Finally we struck the trail, and an hour later were sitting down to an immense meal, but I never, never stirred abroad again without a compass.

I have said that in my opinion the late autumn and early winter are the seasons when game (excepting bear) is most easily stalked and shot. But you must provide against cold, that may prove intense. Blankets are a sorry protection during nights when the mercury falls many degrees below zero, and I would strongly urge every sportsman to provide himself with a sleeping-bag and also a thick Tam o' Shanter. During one of my expeditions I had a professional antelope-hunter with me, who was supplying a railroad with venison. And, curiously enough, he, a hardened veteran, was badly frost-bitten, whilst I, the tenderfoot, escaped scotfree. We carried a small stove amongst our impedimenta, and a blessed comfort it proved, being 


\section{Life and Sport on the Pacific Slope}

a source of light in the long evenings, as well as warmth. At the risk of provoking a laugh or a sneer I shall advise the tyro to add a rubber hotwater bottle to his kit. Upon a night that is likely to prove extra cold, a good jorum of whisky and water and the hot-water bottle in combination will keep you snug and warm when others are shivering. It would be unwise to use the hot-water bottle regularly, but in cases of necessity it is worth its weight in gold.

In conclusion, Big Game shooting, like everything else that is really worth while, exacts all the virile qualities. A cheery resolution to meet disappointment and adversity with a grin will tide a man over many a weary hour. For this reason alone it is well to pick your "pal." A churl, no matter what his other qualifications may be, will poison your pleasure; and his sour looks will breed snarls and growls amongst your hired men. Some mighty hunters prefer to hunt alone with a trusty Indian. Most of us, however, have no stomach for pleasures unshared by a friend. Around the camp-fire, I have spent some of the happiest hours of my life. Would they have been happy had I been alone? I doubt it.

No man should brave the hardships of the wilderness unless he be strong of body; and even the strongest suffer at first. For a fortnight you sleep badly and wake stiff and unrefreshed, but when your apprenticeship is served, you reap a rare reward. The exhilaration of high health is a gift of the gods known to few who dwell in cities. The plain living, the pure air, the hard exercise, the 


\section{Big Game Shooting}

exciting sport, bring an extraordinary vigour and vitality; and yet I have seen men return from the hills and forests utterly worn out - physical wrecks. They had tried to do too much in too short a time.

Verbum sap. 



\section{XV}

SMALL GAME SHOOTING - I 



\section{XV}

\section{SMALL GAME SHOOTING - I}

TPON and around our ranch were vast stretches of low sage-brush that harboured quail innumerable. Then it was easy - not so very easy, for we were rank shots - to make big bags, and the difficulty lay not in killing the birds, but in the disposal of them afterwards. For our neighbours had no "use" for quails (nor for sweetbreads, which we obtained from our butcher for nothing); and in time we, too, tired of the bird's peculiar flavour. In Kibroth-hattaavah, we are told, six hundred thousand men fed upon these birds for a full month, until the food became "loathsome" unto them; and it is said in California that no white man can eat one quail a day for thirty consecutive days: toujours perdrix!

Callipepla Californica, however, must not be confounded with the bob-white (Colinus Virginianus), nor with the tiny Chinese quail who is kept for fighting purposes, and to warm the hands of his owner. Our bird is the Beau Brummel of quail, a dandy at all seasons, even in extreme old age. Who does not admire his dapper surtout of greyblue, his sporting waistcoat of brown and white, his black, glossy crest, his polished extremities, and his charming manners in captivity?

And what superb sport he affords! 


\section{Life and Sport on the Pacific Slope}

Near the ocean, separated from it by a long line of sand-dunes, blazing white in the sun, amethystine in the shade, lay our quail grounds. You could shoot till you were tired, then bathe, then lunch, then shoot again till dusk. It was never too hot, nor too cold. The sea-breeze kept you company, and in your ears was the melodious roar of the surf. The picture has stamped itself on our memories; in the foreground the grey-green sage-brush, soft, velvety, and aromatic; then the dunes fringing the Pismo Bay, and back of all, the enchanting Pacific, with the long, smooth rollers sliding across its placid surface, and crashing upon the hard, dun sand. A- and I shall never enjoy such shooting again. The quail would rise in enormous bevies, scatter out, and settle within fifty or a hundred yards. Then we would advance slowly, the retrievers well to heel, and flush the birds, singly and in pairs. One might suppose that the quail enjoyed the fun, so willing were they to lie snug, so complaisant in giving the worst duffer that ever fired a gun a dozen chances. They scorned the thickets in those halcyon days, and always flew straight away, low and fast, and on a horizontal line. $\mathrm{Z}-$, a member of the English colony, counted himself the laziest man in California, but even he shot quail fifteen years ago. This youth rose not with the lark, and, clad in flannel shirt and trousers, his red, good-natured face crowned with a sombrero, would ride bare-back - he was too lazy to saddle his pony - to pleasant Pismo. His bronco, a mild beast, never objected to carry a light fishing-rod beneath a coarse tail, that lay tight 


\section{Small Game Shooting}

as the dorsal fin of a mackerel, between the gluteal muscles. $\mathrm{Z}-$, when questioned, would assure the native sons of the golden West, that in England, where the sun never shines, all horses, even hunters, were so trained to carry umbrellas - and many believed him! The story has an apocryphal twang, but it is true. With $\mathrm{Z}$ - as mounted escort, A- and I would drive to the shore in a roomy spring-waggon that held ourselves, our dogs, our ammunition, and a generous luncheon. Upon the beach were clams, big, juicy clams, good when fried, better still in chowder, and best of all baked in fragrant sea-weed; but we were faithful, I remember, to sardines, potted meats, foie-gras, cheese, and marmalade; and we drank freely of a wonderful brown sherry, the pure juice of the Californian grape; and we told the old, old stories of the birds we had just missed. We missed about three out of four shots. Often a stranger would join us, generally a pot-hunter, a ground sluicer, whom we held in contempt and derision (doubtless he thought us extravagant maniacs), and also in fear, justly considering the condition of his ancient ram-anddam gun. As a rule, A- would dismiss the stranger with words as sweetly seductive as the brown sherry. Sometimes we would encourage the unwelcome guest to lie. Once we met a youth who swore, by Jing! that he never shot quail except on the wing.

"Are you a good shot?" demanded A-.

"I ain't an expert - yet," replied the youth modestly. "But I pack home as many quails as most. Yes, sir, I do purty well fer a beginner, 


\section{Life and Sport on the Pacific Slope}

purty dog-goned well! Lemme see. Now, yesterday I went a-huntin', and I packed along jest ninety-two cartridges, - no, I can't lie to ye, boys, 't was ninety-three. I'd disremembered that one missed fire. Well, sir, I used up them shells, all but three, and I showed them to maw when I got home. You can ask her if it ain't so. I'd three shells, gen'lemen, and jest eighty-one quails - all single birds. Yes, sir - all shot on the wing. Some day, boys, I hope to be an expert."

I can see my brother's face as he listened attentively to this remarkable yarn.

"My boy," said A—, solemnly, "you may or you may not become an expert quail-shot, but you are to-day the biggest liar in Christendom - bar none. And I'd like to shake your hand, and compliment you. If you'll stay with us and tell us one more gilt-edged lie, we 'll give you lunch and a glass or two of sherry."

The youth declined the invitation.

After a time we learned to hit these gentle quail, and others learned the knack; and then, alas! came the railroad, and the subdivision of the big ranchos, and dozens of settlers, who slaughtered the birds in and out of season, on the ground and on the wing, till finally the sage-brush that they loved knew them no more, and the survivors - if survivors there were - betook themselves to the chaparral, to the tangled thickets of manzanita, to the tops of the coast range, anywhere and everywhere, away from the insatiable enemy. So the golden age of quail-shooting passed away.

Of course some grounds still remain virgin terri- 


\section{Small Game Shooting}

tory, but to reach these the sportsman must travel far from all settlements, and camp out. A- and I annually organise at least one such expedition, and return with strings of the slain, now thankfully accepted by our neighbours; but as both of us are more or less tied to the ranch, we have been constrained to take to the mountains close at hand, and there have learned at last the art of shooting quail with all the odds in favour of the bird and against the gun. It is a day of small bags and very hard work, and we have been forced to study systematically the habits and habitat of the game. Till a sportsman learns to do this, he may be said to be still unbreeched.

For quail are crafty as foxes. For instance, we will suppose that a bevy has been flushed, and, rising out of range, has flown a quarter of a mile and lit in a steep gulch bristling with brambles and scrub-oak, - a favourite place. The veteran will waste no time in following his quarry, for he knows that they will run swiftly up the gulch, across the crest of the hill, and probably be lost in a heavily wooded cañon upon the other side. When he stands, breathless, upon the spot where the birds settled, he is not surprised that they are not there, and, as he pauses, he probably hears a cock call half-way up the gulch, "kah-kah-ka-0-0-w!" In reply there is a peculiar chatter from a bird, evidently concealed close by - a sentinel; and after that not a sound; but the wise man will infer that the main body of the bevy is running ahead as fast as their sturdy, well-muscled legs can carry them. Again, we will assume that a big band has 


\section{Life and Sport on the Pacific Slope}

been duly scattered and fair sport enjoyed. The guns have beaten the ground thoroughly and know that perhaps a hundred birds are lying here and there within a radius of half a mile. It is time for luncheon, and men and dogs are fagged out. The tyro will be sure to sit down, eat his sandwiches, and discuss the sport at the top of his voice. Not so the experienced market-hunter. He will steal quietly away, and munch his bread and cheese in silence and seclusion. Presently he will mark a cock-call, then another, and another. Before an hour has passed the bevy will have reassembled; his dog will find them, and perhaps a better bag will be made than before. The tyro, on the other hand, must find another bevy, for the quail, hearing voices, have not come together.

The finding of bevies in a rough country is no easy matter. Highly trained setters, field-trial winners who range at full speed are almost useless in the mountains. If you are happily able to keep them in sight they may stand to birds in places where two-legged creatures must crawl. As a rule the market-hunter finds his own bevies, drives them into country where the birds can be picked up when shot; and for this purpose uses a dog trained to range within twenty-five yards of his master. In a dry country like ours, where springs are scarce, the dogs should be lean as a coyote, hard-footed, for sticker-grass abounds, with the keenest eyes and a sensitive nose. An English setter, trained by a market-hunter, is in our opinion the best dog for work in the coast range, but some prefer the pointer. My brother still owns a veteran, half-spaniel, half- 


\section{Small Game Shooting}

setter, who was a wonder in his youth. He is not quite so accomplished as the retriever we have all heard of, who would stand on his hind-legs, shade his eyes with a paw, and mark down wounded birds falling half a mile away; but he made less mistakes and retrieved his quail more quickly and noiselessly than any thoroughbred I ever saw. However, we never used him to find the bevies; that part of the work we learned to do for ourselves. After rain and heavy fog, the birds will always be met with in the low brush, in sunny sandy patches, or amongst warm sandstone boulders. Upon fine mornings you are sure to flush them at the head of small cañons. Upon pipinghot days they seek the thickest brush and water, if water may be found. They have regular roosting-places and invariably work towards home of an evening. If it be raining you will explore the dense manzanita; and then, if you can drive them into low brush, they will lie like stones, and the whole bevy can be exterminated by a ruthless pot-hunter.

The bevy "located," you will do well to consider the direction of the wind and the general lie of the country before planning the campaign. Upon the intimate knowledge of a dozen seemingly unimportant trifles hangs success; one mistake spells failure, fatigue, and demoralisation of dogs and men. The northern slopes of the foot-hills are covered with high chaparral, and the quail will make a desperate effort to reach what they know by long experience to be sanctuary.

One fine morning, last October, we found a big 


\section{Life and Sport on the Pacific Slope}

bevy at the head of a cañon situated between our ranch and the ocean. There were three of us, the right number, $\mathrm{A}-$ and I and our guest, a famous shot in the old country, hard to beat upon the moors or at a hot corner, but a heavy-weight, not quite at his ease beneath a Californian sun. To our left lay a fine stretch of sage-brush, intersected with small gulches; above this some open ground, and yet higher some steep sandstone cliffs. We decided to drive our birds into the sage, if Diana permitted; and by spreading out, by shouting, and with furious tapping of brush and branches, succeeded in scattering the quail over the delectable slope. Then, in a straight line, our friend in the centre, we breasted the brush. Suddenly a single bird whirled into the air, turned sharply to the right, and whizzed at a double angle behind us and downhill. A- dropped him stone dead with his second barrel, and then asked our guest, at whose feet the bird rose, why he had not fired. Bruno trotted up with the quail, and the stranger examined it with interest. "By Gad!" he exclaimed, with a jolly laugh, "it's not eight inches long, and it frightened me out of my wits!" Five minutes later we are in the thick of what may be called the hardest and finest wing-shooting in the world. The birds, with a strong trade wind behind them, twist and turn like snipe, dodging in and out of the taller bushes, flying upward, downward, to the right and left, skimming the ground, facing the guns sometimes, in a plucky attempt to regain the thick woodland behind us, and presenting in short every conceivable kind of shot. Fortunately we 


\section{Small Game Shooting}

are fresh and in wind, so we kill half of the birds fired at, - a fair average in a rough country. In three quarters of an hour the fun is over, the runners are retrieved, and A- opines that a dozen quail may be flushed in the cliffs above us. Climbing these is stiff work, and a brace escape untouched as we stagger on to the summit. Here, a détour is made in the hope of turning what birds may be found into the brush we have just left. Nor are we disappointed. The quail lie snug amongst the warm boulders, and when flushed fly back-dropping like bullets down a well. A- misses four in succession, and his dog looks at him in solemn disgust. After fifteen years' practice we confess that the knack of killing quail dropping with folded wings down a precipice has not yet been vouchsafed us. Two angles - for the birds curve outwards - must be nicely calculated, and also the speed of the object, which varies according to the strength and direction of the wind. The reader, at ease in his arm-chair, will kindly remember that a cliff has just been scaled, that each man carries fifty cartridges, some dead birds, and his luncheon, and that none of us is a youth. Thoroughly blown, we sit for a moment beneath the shelter of a scrub-oak, and Prince, with lifted head and paw, advises us that a quail is concealed in the thick foliage above. He must be dislodged by a stone, then he will fly slantwise from the top of the tree, close his wings, and drop. A — offers to bet our guest two to one, in cigars, on the bird. It is agreed that the shooter must himself shy the stone and then fire. Our guest 


\section{Life and Sport on the Pacific Slope}

wins the bet, and quite recovers his temper. The night before he had talked rather contemptuously of quail-shooting; now he is humble, but very enthusiastic.

We spend ten minutes on the summit, inhaling the crisp, fragrant air, and pointing out the different landmarks. Below, to the west, lies the Pacific. The herring are in the bay, and we can see the big pelicans a-fishing, accompanied by their parasites, the gulls. Some streamers of grey mist steal quietly across the waters, and out of a fog-bank to the north comes the weird scream of a siren. We tell our visitor of the fish we have caught in this summer sea. We point out the marshes where we have slain hecatombs of ducks. Through the lowlying land, like a silver serpent, winds the creek that once swarmed with trout, and at its mouth we have caught and still can catch, steel-head trout, that take the fly and afford glorious sport for a too brief season each year. A- points out a deep cañon where black-tailed deer may still be found, and sighs as he speaks of the countless herds of them that roamed through these foot-hills in the seventies and early eighties. A- is a laudator temporis acti, and not without reason.

Then we descend the cliff, and, passing through the sage-brush, bag a few more birds. The day being very warm, we are constrained to beat the thickest covers, and flush at last another bevy, that swings into a gulch and from thence scatters into high chaparral. We walk through the thicket close together, and miss many snap-shots. A woodcock, flitting through hollies, is an easier mark than a 


\section{Small Game Shooting}

quail whizzing between scrub-oaks and grease-wood. Soon the brush becomes impassable, so we sit down and wait. Presently a cock calls, and our ears catch an answering note from a distant gorge. A- glances at me and shrugs his shoulders. We know that a monstrous bevy rises in this gorge, but it is a labour of Hercules to dislodge it. Fired, however, by the presence of our friend, we agree to make an attempt after luncheon. So we retreat to a spring, water the setters, eat our sandwiches, smoke our pipes, and then plunge doggedly into a wilderness of manzanita. The stiff, red branches scourge us pitilessly as we struggle through, and before many minutes have passed the three of us are on hands and knees, crawling at snail's pace up a steep hill. After twenty minutes' climbing, when hope deserts us, when hearts beat furiously against ribs, and every bone and sinew protests against a further advance, we hear a soft cluck, cluck, cluck - as of feeding chicks, then silence, and then a vibrant whir-r-r, the frenzied fluttering of a thousand wings, a thrilling sound, sweeter in our ears than the bel canto of a Trilby, a sound that begins fortissimo and melts in an enchanting diminuendo into silence. We know where the birds have gone, and a laugh breaks from A-'s lips. The choir invisible has flown straight up-hill to a potrero, a piece of tableland covered with low brush, an ideal spot for quail-shooting. The October sun is blazing hot, and the perspiration streams from our faces as we crawl up and onwards, but the heat will anchor the birds as surely as if strings were tied to them: 


\section{Life and Sport on the Pacific Slope}

so we rejoice and smile grimly, thinking of the prospective slaughter of the innocents.

When we tumble into the open, A-calls a halt, and we sip a little whisky diluted with cold tea, and examine our guns. Then we advance slowly, our fingers tingling for the trigger. We have agreed to fire if the bevy rises out of range, so as to scatter the birds, and when we do flush them, a moment later, are amazed at the number. The sun is almost eclipsed, and they spread out as in the beaux jours d'antan, fan-shaped, settling like a soft, blue-grey cloud amongst the feathery lupin and sage.

We made a tremendous bag, for the birds, living secure in what was practically a sanctuary, had seldom been shot at, and were comparatively speaking tame. They were flushed in pairs and threes; and our friend bolstered a reputation that had been sorely tested during the morning. But of course such sport is accidental: A- and I count ourselves lucky if we bag a dozen birds apiece after eight hours' hard work. It is safe to prophesy that the quail in the coast ranges will never be exterminated, as few sportsmen are willing to undergo exercise that puts to the proof brains, lungs, heart, and muscle. All said and done, I know of no finer sport. It is, and always will be, the sport of California. You shoot ducks standing at ease behind a blind; you kill snipe wading leisurely through a marsh; you bring your wood-pigeon down from the skies as you lounge cool and collected beneath the shelter of the oak whose acorns are the bird's food. But quail - unless you are prepared to wan- 


\section{Small Game Shooting}

der far afield (and then the disposal of the game presents an almost insoluble problem to the amateur) - quail, I repeat, must be hunted scientifically and killed, as has been said, with the long odds in favour of the bird.

They pair in February, and the first brood hatches out about the end of April, the second about the last of June. When the hen begins to lay the second batch of eggs the male takes charge of the first brood. Often the birds do not pair, but remain in bevies, although the females, without doubt, lay eggs in another's nest. If the hen be killed, the cock will hatch out the brood, and he sits on the eggs while his mate is feeding.

Longfellow uses the verb pipe in connection with the bob-white, -

"It was autumn, and incessant

Piped the quail from shocks and sheaves ;"

but pipe expresses inadequately the peculiar note of the Californian bird. Indeed, no musical instrument, save the human throat, can produce a perfect imitation of a cock-quail's call. I believe them to be accomplished ventriloquists, using their art consciously. A killdee will lure a boy from her nest by pretending to flutter along the ground as if badly wounded. And a quail is surely more intelligent than a ring-plover. 



\section{XVI}

SMALL GAME SHOOTING-II 



\section{XVI}

\section{SMALL GAME SHOOTING. - II}

R ESIDES quail - duck, swan, geese, snipe, grouse, 1 pheasants, pigeons, doves, ptarmigan, hares, and rabbits may be shot upon the Pacific Slope. We used to make tremendous bags of duck, but to-day it is impossible to secure more than a few birds in marshes where ten years ago they were slain by the hundred. In certain parts of California and Oregon there are Duck Clubs, the exclusive preserves of millionaires, but public opinion, as I have already said, is bitterly opposed to game preserving, and the law imposes but a trifling fine for trespass. In consequence the Club records show a decrease in the numbers of birds shot, and the price of a canvasback in a good restaurant is some eight shillings.

In the good old days, the ducks flew low, and seldom left the marshes. Four guns properly posted were sufficient to keep them flying up and down the sloughs from dawn to dusk. To-day they fly high, almost out of range, and soon depart for the ocean, returning to their feeding-grounds after dark. The big ducks, like canvasbacks, mallards, and sprigs, fly at a tremendous pace (some say ninety miles an hour), and to tear them down out of the skies taxes the skill of the sportsman and the quality of his gun. As they sail over your right or left shoulder, it is necessary to aim well forward of the tip of the 


\section{Life and Sport on the Pacific Slope}

near wing, for shot are dropping at sixty yards, the initial velocity (eleven hundred feet to the second, I believe) being less than is generally supposed. As a rule the shot goes under the bird. I can compare this kind of shooting with that of killing high rocketing pheasants driven out of hill coverts over guns posted in a valley. As with the pheasants, you must swing your gun with the bird and continue the swing after you pull the trigger. The same golden rule holds good with ducks flushed out of rushes. They are rising fast, and unless the gun rises at the same angle and pace, the bird, although seemingly an easy shot, is missed or tailed. Speaking of driven pheasants reminds me of amazing blunders made by Americans upon this subject. For instance, so brilliant a writer as Mr. Charles Lummis in his excellent book on Mexico (I cannot quote verbatim) sneers at the Englishman who shoots at battues. According to these critics tame pheasants flutter up in clouds before the guns, and are ruthlessly slaughtered. ${ }^{1}$ Not a paper of any importance

1 Since writing the above paragraph I have read a book on America called "The Land of Contrasts," written by Mr. Muirhead. Mr. Muirhead is an Englishman, and in the chapter on Sports and Amusements he goes out of his way to stigmatise a pheasant "shoot" at Highclere Castle as "a long drawn-out massacre of semi-tame animals." Amongst the guns was Lord de Grey, the finest game-shot in the world. Those who have had the pleasure of seeing Lord de Grey shoot know that he cares nothing for easy shooting; that he prefers to stand back of the guns where the "rocketers" present the hardest shots. Mr. Muirhead says: "It is certain" (the italics are mine) "that the pheasants in the bag must have been nearly as tame as barn-door fowls." It is sufficient to add that Mr. Muirhead, who writes most ably and convincingly upon most topics, is here writing nonsense. He can never have seen a good "shoot" in his life; 


\section{Small Game Shooting}

upon the Pacific Slope has withheld criticism upon this subject. Grouse drives, partridge drives, pheasant drives provoke bilious comment. It would be impossible here to write a full defence of methods approved by the cream of English and Continental sportsmen, but it may be observed that driven birds are never easy, but on the contrary very difficult shooting. They fly at a high rate of speed; if hit, they are generally killed, and they present an infinite variety of shot. The old-fashioned sportsman liked to see his dogs work - and who does n't ? - but modern agriculture, which strips the fields of stubble, has made this form of sport impossible in England. More, the old-fashioned sportsman, accustomed to shoot his birds from behind, would be sure to miss a rocketing pheasant driven at him. Indeed, so far as these big and rather clumsy birds are concerned, the only sportsmanlike way to kill them is by driving, and when they are flying over tall trees with a wind behind them it

and any English sportsman could have told him that the pheasants at Highclere do not present easy shots. These birds, that in his ignorance the writer alludes to as barndoor-fowls, come out of the Highclere coverts high up and flying as fast as it is possible for pheasants to fly. To make such a bag as Mr. Muirhead records, the most extraordinary skill and endurance on the part of the guns are required. If the old-fashioned sportsman attempted to fire off as many cartridges as Lord de Grey did on this occasion he would probably be taken home on a litter, paralysed in his muscles and a prey to a splitting headache. Mr. Muirhead and gentlemen like him who write of English institutions should be more careful. The international misapprehension of so many subjects which Mr. Muirhead deprecates is largely due - as I have said before - to ignorance. Who would blame Mr. Lummis should he accept Mr. Muirhead's indictment of battue-shooting as " confirmation strong" of his own published opinions? 


\section{Life and Sport on the Pacific Slope}

takes an artist to touch them. Having digressed, I may as well continue down a path which has always proved thorny to me. English sport, as practised by the finest shots and riders in England, seems to be entirely misapprehended in America, particularly in the West. Years ago, I remember a long article on fox-hunting which appeared in a first-class weekly paper. From beginning to end the writer displayed an ignorance of his subject that was absolutely monumental. I wrote an answer, temperately worded, giving a few statistics, stating what fox-hunting represented in dollars to English farmers, the number of men employed, the number of horses bred for hunting, and so forth. My letter was not inserted. It would be well for writers about to abuse modern English methods of shooting, to consult some text-book (there are many) of sport, and to learn what these methods mean for the masses. Not only do thousands of men find healthy and remunerative employment, but hospitals and countless poor families throughout the land are given large quantities of wholesome and delicious food. It is not too much to say that if the game laws of England were abolished, game would never be eaten at all save by the very rich who could afford to import it.

None the less, nearly all men not past the prime of life prefer'good wild shooting when they can get it. And to most, a mixed bag has superlative charms. We seldom returned from the marshes without mallard, canvasback, sprig, redheads, teal, widgeon, and snipe, with here and there a goose or brant, and very occasionally a swan. There are 


\section{Small Game Shooting}

other varieties of duck, - spoonbills (very poor eating), wood-ducks, and butter-balls, - but the firstnamed gave us the finest sport.

We imported a Berthon boat, which would fold up and lie easily in the bed of an ordinary springwaggon. The boat held two persons and proved most useful, although very easily upset. As a rule we stood in high rushes, wearing long "gumboots," with decoys spread out upon the water in front. You crawled into your "stand" before daybreak, and mighty cold work it was, turning out of warm blankets into half-freezing water. As retrievers for ducks we found nothing better than spaniels: most of them are slow, but they keep warm and are easily trained. In the East, I am told, they employ trained ducks as decoys, but I have never seen them in the West. Some of the market-hunters use duck-calls, but the note must be faithfully reproduced or the ducks will take no notice of it. And every variety of duck has a different quack.

I shall never forget those early mornings in the marshes: skies and water of the colour of amber, the marshes russet, with here and there a patch of emerald, - the bright green moss of some quagmire. Peering out of the tall "tules" we could see the duck approaching. The widgeon were innumerable - lines and lines of them. As they saw the glint of our barrels they would soar up, and the morning's light would blaze on their breasts. Coming straight over your head you wait till the bird is lost at the end of the swinging gun; then - pull, and down he comes - stone dead - with a mighty 


\section{Life and Sport on the Pacific Slope}

splash! The canvasback and mallards fly higher and faster in more solid phalanx. The wings of the widgeon seem to whistle: a sound not to be mistaken, but the heavier ducks come with a whir and a rattle. Soon the morning shoot is over and you return to camp and breakfast with many birds at your belt. Oh, those cheery breakfasts! And the good tobacco afterwards, and the talk and the chaff! Then the guns are wiped out, the cartridge belts refilled, and you draw lots to determine upon whom the task devolves of flushing the ducks for others to shoot at. Not till evening will the birds fly of their own accord.

Fortune ordains that the shortest straw is drawn by you, so you walk briskly off to the lower end of the marsh, while the others post themselves at different points. You will have plenty of fun and plenty of hard work before you see camp again. Just round that corner is a small pool screened by low rushes, a favourite feeding-place of the mallards. Listen, and you will hear them. As you crouch down, your spaniel crouches too, and together you steal through the rustling grasses. Confound it! They are not to be caught. With a mighty whir-r-r, and Homeric quackings the splendid birds take wing. You watch them fly up the marsh - too high up, you think, for the ambushed guns. Not so. Even as you strain your eyes into the blue, two of the birds fall, and the double report of the gun floats to your ears. Good old A-! His sixteen-bore (which the market-hunters regard as a pretty toy in comparison with their huge tenbores) has vindicated the famous name upon its 


\section{Small Game Shooting}

barrels. As you plod on you hear another double shot and turn sharply, but the ducks are now beyond your sight. Halt! What is that? A line of geese, grey geese, not the white and uneatable variety. Are they to be stalked? For be it known that the grey goose is a wily bird, hard to kill as a Boer burgher behind the rocks of his veldt. Anyhow it is worth a trial, so you tie the spaniel-much to his dismay - to a sage-bush, and stop his whimpering with a gentle cuff. Then, flat on your stomach, you wriggle slowly towards the thin grey line. Presently you stop, for as luck would have it, a cowboy is riding near the geese. They will let him come quite near, and he may take a pop at them with his six-shooter. Then the odds are they will fly over your head. Just so. The geese rise majestically, and the old gander leading them steers straight for the Polar Star. The birds fly in a " $\mathrm{V}$ "-like wedge, one behind the other, and you pick out the third on the left. By Jove! They must be higher up than you supposed. You have hit the fourth. He comes sailing down with a broken wing, and you give him the second barrel as he tries to make off into the rushes. What a superb bird it is!

The spaniel licks your hand as you untie him, and smells delightedly the goose, which you hide at the foot of the sage-bush. There is now a big piece of shallow water in front of you covered with widgeon. These you flush for the benefit of those behind you. They rise far out of range and presently you hear a fusillade from the north. Here they come back again. You are snug behind 
296 Life and Sport on the Pacific Slope

a clump of "tule," and get a nice right and left as they whistle over. One falls dead at your feet; the other, wounded, strikes the slough, and the spaniel is after him in a jiffy. The duck dives and the dog is puzzled. He turns to you imploring eyes. You wave him toward a mass of weed. There is a flounder and a gurgle. Good dog! What a nose he has!

At the lower end of the marsh you flush a jacksnipe and miss him clean. Evidently the early rains and heavy frosts in Oregon have sent the snipes south. This will be glorious news to take back to camp. Meantime you are stirring up the duck, getting a few shots here and there and driving them north. The "boys" are blazing away and must have a bag already. Gad! how hot it is!

When you return to camp, the guisado, or Spanish stew, is scenting the air, and you fall to with an appetite worthy of it. The recipe for this savoury dish is as follows: Into a large iron camp-pot you put some butter, in which you fry brown a couple of large onions carefully shredded. Then you add the contents of two big tins of tomatoes and three dried chillies. Plenty of salt and what game may be in camp fill the pot. The whole must simmer in the embers of a camp fire for four hours. After eating your lawful share of this you can say with the poet, -

"Fate cannot harm me, I have dined to-day."

If, however, you consume more than is needful, Indigestion, masquerading as Fate, may present a bill of pains and penalties. 


\section{Small Game Shooting}

After dinner comes the inevitable nap, the siesta of the Lotus Land, and then the camp is put in order. At five you prepare for the evening shoot. Then follows supper, and the yarns and songs of the camp-fire; and so - as old Pepys has it - to bed.

Snipe-shooting is perhaps more fascinating than any other kind of sport because it comes so seldom. In our county I have known a couple of years to pass without our bringing to bag more than a few birds. And even in the best of seasons, they come and go mysteriously: here in legions to-day - gone to-morrow.

We had the right of shooting snipe in a marsh belonging to a friend of ours, and here we have passed many days for ever marked with red. Our friend was a Southerner, upon whose genial face hospitality was writ large, and his wife was a Scotchwoman, a daughter of the Land of Cakes; so you may believe that we fared well beneath their roof. Not only were the snipe plentiful, but we were sure also of shooting many ducks - widgeon especially - and bordering the marsh was some capital quail-ground. Shooting snipe is a knack; a knack, however, that some men never acquire, partly perhaps for lack of practice, and partly because they will shoot at the bird as it goes away, instead of just above it. A snipe rises as it flies, a quail does not, and I have seen good quail-shots miss snipe after snipe although - as they always explain to me afterwards - they were "dead on" to their bird. 
298 Life and Sport on the Pacific Slope

Most men wear long gum-boots when walking through a marsh, but they make the feet very hot, and unless they fit perfectly are likely to chafe the heel badly. My brothers and I found that light shoes and stockings, which could be quickly changed and dried, were the proper foot-gear, and in these we could tramp up and down a marsh all day in perfect comfort.

In a country where stock is, - cattle, hogs, and horses, - look for your snipe in those parts of the marsh where the stock has broken the ground. This is a hint worth having, for we have noticed without exception that the birds always select such places; and often we have tramped over miles of seemingly splendid snipe-ground without flushing a bird, and then crossing a fence into an enclosure used by hogs, have filled our bags.

You cannot work your ground too carefully, for snipe, when they are not wild, lie close, - another reason which accounts for many misses. A greatuncle of mine told me to murmur "snipe on toast" before pulling the trigger - capital advice, by which I have profited. It is curious why a snipe should upset the nerves, but most sportsmen will testify that it is so. His peculiar "scape" as he swiftly and silently whirls into the air startles even the veteran ; because, perhaps, it is in itself an exclamation of surprise.

In the West (perhaps in the East also) the tenderfoot is sure to be told of an original and certain method of catching snipe. The "boys" will solemnly assure him that snipe will fly into an open sack at night, provided a lighted candle or a 


\section{Small Game Shooting}

lantern is held behind it. The travelling sportsman will do well to listen with keen attention to this ancient joke, and to accept with pleasure an invitation to bag snipe, insisting of course that his kind friends should accompany him to the nearest marsh. When he has set his sack and lit his candle, he can slip back to camp, and the expression upon the faces of the others when they return will be worth seeing.

Grouse and pheasants are found for the most part in the northern woods, and it is seldom that more than a few birds can be shot in a day, There are many varieties of grouse, and many local names for the same variety. Prairie-hens, sage-hens, and ptarmigan are grouse, but the birds most common in the woods of the Northwest are Canace obscurus and Canace Canadensis. Canace obscurus is aptly called the Fool Hen, for the bird will sit on a pine bough and allow you to shoot at it again and again. For such sport a rook rifle is the only weapon (or a pistol). We appreciated these birds most in a pie. The other grouse are not so easily bagged, but the shooting of them at any time is poor sport compared with that afforded by quail and duck and snipe. Of pheasant-shooting on the Pacific Slope I am not qualified to write, having had little of it. Attempts have been made to breed and preserve the English variety (Phasianus colchicus), but - so far as I am aware - with little success. The bird found in Oregon comes, I believe, from Japan (versicolor), and does well in certain places. It would be extremely interesting if the State of 


\section{Life and Sport on the Pacific Slope}

California would undertake the breeding and preservation of the English pheasant in some such place, let us say, as the Yo Semite Valley, which might be made a sanctuary. A pheasant is extremely delicate when young, but an old bird is hardy enough, and I am of the opinion that a sustained and practical effort to add this splendid specimen to the list of Californian game-birds would be crowned with success.

Dove-shooting is capital fun. In southern California the doves are to be found in most stubble fields after harvest, but only the tyro will care to shoot them as they flutter up in front of the gun. The sportsman will take his stand toward sunset near some pool or spring where the birds fly to water. If the spot is properly chosen, he will have an hour's excellent sport. The birds fly at a great pace, presenting every kind of shot, circling and swooping, now high, now low, and being about the same size as a snipe are no easy mark. In our part of California and particularly upon our ranch, the dove-shooting used to be superb, but it is today only middling, for reasons that I am unable to guess at. Certainly much more land is ploughed, and the doves feed on the wheat and barley that is left on the fields, and the weed known as doveweed still grows in profusion, but the birds are decreasing in numbers. Fat, they are nearly as good to eat as ortolans; lean, they are only fit for a pie. Curiously enough, we never experienced the slightest difficulty in disposing of our dead doves. Nothing exasperates a man more than to shoot 
game which cannot be eaten, and I have seen the day when a brace of mallard were hardly worth a "thank you" to our neighbours, but the doves were never refused.

Speaking of game as food reminds me that all over the Pacific Slope, ducks, snipe, and quail are as a rule vilely cooked. I except the clubs, a few restaurants, and of course many private houses. The ducks are overdone and sometimes stuffed with sage and onions! The quail are split in two and broiled. The snipe are robbed of their trail and baked till they are dry and tasteless. Quail in particular demand considerable care in the cooking, and - if the weather permits - should be well hung. Many housewives skin them! They should be carefully plucked, draped with bacon, and roasted. The more you baste them, the better they will be, and they should be served, like English partridges, with gravy and breadcrumbs. We always add bread-sauce (against which there is a prejudice in the West), and enthrone them on squares of crisp, well-buttered toast. There are many other methods, but this preserves the delicate flavour of the bird and prevents the flesh from becoming dry and tough. In camp we cook them with tomatoes and corn, allowing them to simmer for hours, and so treated they may be highly commended. The Indians covered them, feathers and all with clay, and placed them in hot embers; then the clay was chipped off, the feathers coming away with it, and the bird eaten. I have tried this recipe, - only once.

The wood-pigeons are plentiful in the fall of the 


\section{Life and Sport on the Pacific Slope}

year when the acorns are ripe. If the acorn crop fails, you see few pigeons, and at all times they are very wild. However, in the morning and evening they fly across certain divides in the hills, and a couple of guns posted behind blinds may enjoy good sport for an hour or two. Here again you are confronted with the difficulty of giving away your birds, for the wood-pigeon is a tough customer to eat, as he is to kill, and his flesh often has a bitter and unpalatable flavour.

Of the hares (jack-rabbits) and rabbits (the cotton-tail), there is not much to be written. I can remember the time when jack-rabbits were never eaten, and the prejudice against them still lurks in the breast of the Native Son. When free from disease they are a wholesome and delicious food, and make a civet fit for Lucullus. In Fresno, where the jack-rabbit is a plague, the farmers systematically drive the rabbits into an enclosure, where they are killed by the thousand. In some parts they are coursed; and in early days the vaqueros used to ride them down, - a by no means easy feat. For a reason that I cannot logically defend, this form of sport always seemed to me cruel. I once saw a rabbit chased by a horseman, and at the end it leaped from a high cliff into the Pacific. But the argument that would condemn the vaquero would condemn also the fox-hunter, so I made no protest at the time, although I have never taken part in that particular form of sport again. The ethics of the chase are in a Gordian knot that I for one am unable to cut.

The cotton-tail, darting from bush to bush, is 


\section{Small Game Shooting}

good to shoot, and when shot good to eat, - his flesh being white and delicate in flavour as a chicken's. They abound in the brush foot-hills and have furnished food to many a poor squatter.

Sportsmen coming to the Pacific Slope for the small game shooting will not be disappointed if they engage as guide a professional market-hunter. I have always found these men to be capital fellows, excellent shots, fair camp-cooks, and learned in the lore of Arcadia. They will provide the camp equipage, dispose of the birds shot, and good sport will be assured. Commission merchants in Portland, Tacoma, San Francisco, or Los Angeles will furnish the traveller with the names and addresses of a dozen Nimrods. It is wise, also, to have a chat with the local gunsmith. He will be glad to sell you your cartridges and to give you some practical hints. But, remember, information gleaned at second-hand must always be well salted. And in making a contract with a market-hunter, it will be wise on your part to fix his remuneration according to the sport he shows you. You can afford to be generous if he takes you to the best places, and your money will be well spent. 



\section{XVII \\ SEA FISHING}





\section{XVII}

\section{SEA FISHING}

$7 \mathrm{HE}$ fish to be described in this chapter are 1 the tuna, the king-salmon, the albicore, the yellow-tail, the black bass (or Jew-fish), the halibut, the bonito, and the barracuda. These, taken with rod and line, will furnish the sportsman with three months' ample entertainment.

The following excerpt from an article written by my friend Professor Charles F. Holder for the Cosmopolitan magazine is worth quoting:-

"The activity of the tuna is only comparable to that of the tarpon. I have seen them leap ten or fifteen feet in the air, while they have been known to jump over the boats in pursuit of them. Sportsmen from the East have devoted weeks to this fish, hoping to win fame and honour by taking one on a rod, but so far the tuna has harvested the rods, reels, and lines, and is still master of the situation."

Since those lines were written in '95, some twenty-nine sportsmen have succeeded in bringing this superb fish to the gaff. The first was killed by Col. Morehouse, of Pasadena, in 1896.

As the tarpon is to the fish that swim in Atlantic waters, so is the tuna to the finny tribes of the Pacific. Conceive, if you can - for imagination staggers behind reality - a gigantic mackerel from 


\section{Life and Sport on the Pacific Slope}

five to seven feet in length, and weighing from one to three hundred pounds, - a marvel of strength, speed, symmetry, and colour, which bears about the same relation to the coarse and monstrous black bass that the royal Bengal tiger does to the hippopotamus, or Phœbus Apollo to Daniel Lambert!

My introduction to this prince of the Pacific was on this wise. My brother and I were trolling for yellow-tail off the Island of Santa Catalina. The sun had just risen above the low fog-banks that obscured the mainland, and was dispersing with gentle authority the children of the mist that loitered upon the face of the waters. Around us, in palest placidity, was the ocean - vast, vague, and mysterious; abeam, snug in the embrace of bare brown hills, slumbered the tiny town of Avalon. We could see plainly the red façade of the big hotel, the gleaming canvas of a thousand tents, and, dotting the surface of the bay, long rows of pleasure boats, gay with white, green, yellow, and blue paint, whose reflected colours danced and sparkled with joyous significance; for these tender tints, resolved into sound, murmured a rondo of recreation and rest, - a measure enchanting to the ears of work-a-day Californians, whose holidays are so few and far between.

Suddenly, out of the summer sea, a flying-fish the humming-bird of ocean - flashed athwart our bows; and then, not a dozen yards distant, the waters parted, and a huge tuna, in its resplendent livery of blue and silver, swooped with indescribable strength and rapidity upon its quarry, catching it, mirabile dictu! in mid-air. In a fraction of a 


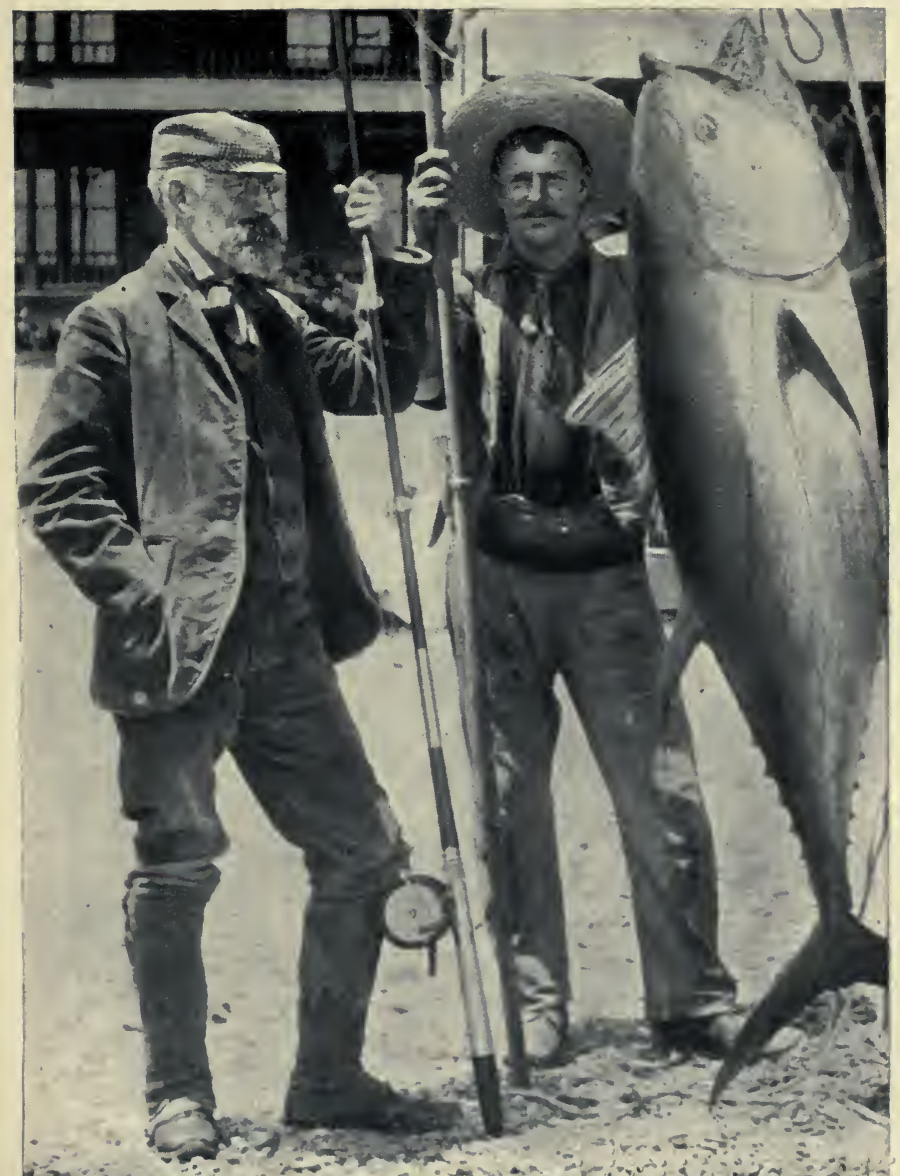

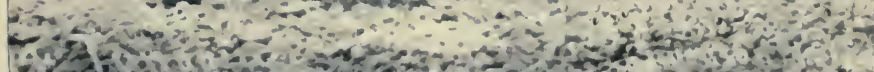

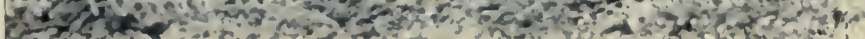
I.EAPING TUNA CAUGHT HY (IIAS. F. HOI.I)ER. 



\section{Sea Fishing}

second the deed was done; the ocean, recording the splash of the leviathan, rippled applause; and our questions pattered like hail upon the somewhat hard understanding of our boatman, a son of Alsace.

"Yes," he said, his white teeth in curious contrast to a lean, bronzed face, - "yes, messieurs, that is a tuna, - a two-hundred-pounder, at least!"

Then he swore stoutly that they were not to be taken with rod and reel. There were men, not more than two or three, who boasted that they had killed tuna with nothing more formidable than a ten-ounce rod and three hundred yards of fine tarpon-line. These gentlemen - so said the man from Alsace were amateur fishermen, and, of necessity, accomplished liars. He could lie himself, upon occasion, but in a modest way.

"Look you, messieurs," he added earnestly, "I, moi qui vous parle, have fished here for these many years; I have seen these fish jump fifteen, yes, twenty feet high into the air; I have lost lines and lines - shark lines and Jew-fish lines that are strong enough to hold a steer; and the tuna breaks them like this - Pouff! Gentlemen from Florida, messieurs, have come to Avalon with rods and reels that have cost hundreds of dollars, but they go away without the tuna-leaving their tackle on the beach!"

For the week following we fished for yellow-tail ; but our thoughts were with the tuna - of him we dreamed by night and talked by day. We met the hero who had captured the first fish in '96, and absorbed the words of wisdom that fell from his 


\section{Life and Sport on the Pacific Slope}

lips. We sat at the feet of another hero, Mr. W. Greer Campbell, who had fished persistently for more than a month, and, eclipsing all records, had brought five tunas to the gaff. Both he and Col. Morehouse had fished for tarpon in Florida; both awarded the palm to the tuna.

"The tuna," said Mr. Campbell, "knows all the tricks of the tarpon, and a few of his own. Both belong to the mackerel family, but the tuna is the high muck-amuck of his clan. You fish for tarpon sitting in a boat, with the bait upon the bottom; you must troll for tuna behind a power-launch."

The days passed, and the speaker added three more fish to his bag; two were gaffed in one day! Four other men had a fish apiece to their credit no more.

"How do you do it?" we asked.

"I fight them from the start," he replied, "and keep on fighting. I know what my rod and reel can stand, and I have the best boatman in southern California. Much of the credit is due to him."

Finally, business summoned the hero elsewhere, and my brother and I secured James Gardner, Campbell's boatman. We also engaged the same launch that Campbell had used, and in my hands were placed the rod and reel that had done such effective work. When my brother met me in the hall of the hotel at 3.30 the next morning the spirit of prophecy was upon him. He vowed that he had slept but a brief two hours, and had dreamed of a gigantic tuna which he had hooked and fought. But the issue of the combat had been left in doubt. 
"I'm not sure," he said, and his face was pale beneath the flicker of a single lamp, "whether I killed the fish, or whether the fish killed me!"

We sallied forth into the darkness and glanced anxiously seaward. A faint light illumined the bay, and across the eastern horizon quivered a bar of silver.

"They're off Abalone Point," said Jim a minute later. "Listen!"

Indeed, splashes were distinctly audible; the sounds floated heavily across the grey waters, and our hearts throbbed responsively as we seated ourselves in Jim's boat, facing the stern sheets, and side by side. The baits were already prepared: two flying-fish, some fourteen inches long. Each was hooked through the head; another hook, connected by piano-wire with the first, was sewn on to the fish's belly; a wire trace, a yard long, and a stout brass swivel completed the lure, which we attached by means of a clove-hitch and a bowline to our lines. Then the launch slipped her moorings, we dropped the baits into the water, and paid out thirty yards of line. The game had begun!

As we gripped our rods, Jim whispered encouragement and advice.

"We'll get a strike within ten minutes - sure! You'll think you've snagged a submarine island, and then the reel 'll tell you that you 've hitched to a shootin' star! Don't snub the son of a gun too much, but check him. When the strike comes, you just holler, 'Let go!' I guess I 'm on to my job, and I'll gamble that you don't lose more'n three hundred feet of line before this boat will be goin' 


\section{I 2 Life and Sport on the Pacific Slope}

with the fish. We're playin' in big luck to find tunies right here the very first time ye go out."

His oars were lying in the rowlocks as he spoke, and the painter was in his strong hands; the launch was nearing Abalone Point. But now, alas! no musical splash proclaimed the presence of the tuna. We sped here and there, now close to the beds of kelp, now heading straight to sea; boxing the compass in a vain quest.

"There they are!" yelled the man in charge of the launch. "Dead astern!"

He put his trim little vessel about as we strained our eyes and ears; we could see nothing and hear as much. The senses of those who go down to the sea in ships are quickened abnormally; we were land-lubbers, and realized the fact with shame.

Zip! Zip! Z-e-e-e-e-e-e!

My brother's reel was screaming for help. In a second Jim had dropped the tow-rope and seized the oars; in two seconds, the blades were gripping the water ; in three, we were slackening speed; in five, we were going astern in the wake of the tuna. The supreme moment had passed. Still the line hissed and smoked through the rings, and the reels shrieked more hoarsely and fitfully as the strong leather brake was applied.

"Check him - check him, sir!" shouted Jim.

"I can't," groaned my brother. "I might as well try and check a runaway locomotive."

I had reeled in my own line and was watching the point of my brother's rod. In fighting these Titans, both hands are needed for the reel. The butt of the rod is placed under one knee, and 
gripped as a bronco-buster grips his saddle; the rod passes over the other knee, and the point of it quivers some three feet above the boat's starboard quarter. To keep rod, line and fish in this position, and in no other, is the duty of a first-class boatman.

"By heaven, he's off!" said my brother, and I groaned in despair as the tip of the rod straightened. "Not he," cried Jim, cheerily. "Reel in, sir, for your life!"

And he did reel in - thanking the gods that he owned a Vom Hofe patent multiplier. For the tuna was still on, and charging like a bull bison.

"Look out for the turn!" said Jim. "When he sees the boat he 'll twist like a swallow."

The warning came not an instant too soon; the tuna fled kelpward, and the reel wailed a miserere that echoed in my heartstrings. If the fish reached that leafy sanctuary, he was safe.

"Turn him!" said Jim, between his teeth.

My brother clapped both thumbs to the brake, but the pride of the Pacific rushed on.

"Harder!" said I — " harder!"

"Lift your leg, sir," suggested the guileful James.

My brother obeyed, eying doubtfully the slender tip. The rod was brand-new, - a raw stripling facing the heavy guns for the first time. Would it stand the awful strain? By Jove - yes!

"He's turning!" said Jim joyfully. "The tunies don't like kelp. Now he'll put to sea, where we can handle him."

And, as he said, the tuna put to sea, steadily, in a straight line; no ocean-going yacht could have 


\section{I 4 Life and Sport on the Pacific Slope}

steered a truer course than he. And the light boat followed. I lit a pipe and smiled complacently.

"It's all right - eh, Jim?"

"All right? Not much! It's never all right with a tuna till he's in the boat."

We skimmed over the water faster than a man could row; then without warning, the boat slackened speed. The fish was sounding and sulking. My brother smiled for the first time, and held up his left hand, which was trembling.

"Don't you rest, sir," said the relentless James. "Lift him - lift him! When he takes it easy, you worry hirn."

My brother sighed and obeyed - using his left leg as a lever. Five minutes' pumping brought the tuna with a rush to the surface; Jim, backing water, approached the quarry, and some forty feet of line were reeled in. Then the tuna sounded for the second time, and the forty feet of line hissed back through the rings.

"He's a big 'un," observed Jim. "It may take three hours of this work to kill him!"

My brother's dream flitted across my memory. A glance at his face was not reassuring. Fifteen minutes' excitement and hard manual labour had set their seal upon him. The tuna could stand severe punishment; of my brother's capacity for the same I was not so confident.

"This ain't a game of croquet," said Jim, crowning my unspoken conclusions. "There was $\mathrm{X}$ He was blooded, too, but it came near killin' the old man. After the fish was gaffed he lay in the bottom o' the boat, limp as a dish-rag - petered 
out, by Golly! We just poured brandy into him, and he's left the tunies alone since that mornin' Thunder! What's he doin' now ?"

The monster had turned, and was towing the boat with renewed vigour towards Banning's Bay - an inlet bristling with rocks and glutted with kelp. For forty minutes the combat was Homeric, but might prevailed. The tuna slowly but surely neared the shore. Then the inevitable came to pass: the line parted!

We whistled for the launch, which hovered near us, and began again; but the fish were no longer feeding. Not a strike was registered. Yet we saw thousands of tuna. An enormous school of them was playing off Lone Point, a cape some six miles from Avalon. Through the multitude and around we passed and repassed. The fish were leaping with such vigour that acres of water were churned into foam ; but our baits were unmolested.

We returned to the hotel in time for a nineo'clock breakfast. The adjective "keen" but feebly describes our condition. Both launch and boat, with their respective owners, were engaged for a fortnight; yet my brother's thumbs were so sore and swollen that the effort of holding knife and fork proved a feat almost beyond his strength. During that day our tongues wagged deliriously. The tuna fever was upon us.

A week glided by, bringing to us bitter disappointment. We fished patiently, morning and evening. The propeller of our launch had a busy time of it. Each inlet, cove, and bay between Seal Rocks and the Isthmus was explored, but the tuna 


\section{I 6 Life and Sport on the Pacific Slope}

would not strike. Despair draped us as with a garment. Early rising and loss of sleep provoked dyspepsia and irritability. My brother and the boatmen stared askance at me: the odious word "Jonah" festered in their hearts and trembled upon their lips. I began to ask myself seriously if indeed I had cast a spell upon these exasperating fish. The very newsboys eyed us with pity. The outspoken sympathy of our waitress became insupportable. The presence of an importunate photographer was an insult. This wretch - he was on the ragged edge of eternity more than once - inspired in us a murderous hate: he dogged our comings and goings; he crushed us with inane questions; he turned us from Jekylls into Hydes!

But our purpose never wavered. We had come to Catalina Island to kill a tuna; a tuna - one at least - must be killed.

"Warburton Pike," said my brother, "spent two years in the Arctic Circle after musk-ox. In this lotus land we can, if necessary, pass the rest of our lives!"

But fate demanded no such sacrifice. According to Jim, who had studied the habits of the tuna, a pernicious ground-swell and the absence of flyingfish were responsible for our ill-fortune, - a case of cause and defect. One heavenly morning the ground-swell was not, and the flying-fish were so plentiful that they banged their heads against the boat.

"This time," said James, "we shall have a strike."

Ten minutes later I hooked a fine fish! $\mathrm{He}$ 


\section{Sea Fishing}

carried out nearly two hundred yards of line, and tried all the tricks known to the mackerel tribe: he rushed here and there like a mad coyote; he sounded and sulked; he towed the boat more than five miles; he circled round us with the speed of a planet careering through space; he jerked the line till it was taut and musical as catgut; he tested every aching sinew in my body, every fibre of the stout rod, every strand of that cutty-hunk line.

But he came at last to the gaff!

$\mathrm{He}$ was so done that he floated belly-up to the steel, and never quivered when it pierced his silvery side. He fought like a lion; he died like a lamb! His beauty, moribund, was indescribable: the deep peacock blue of his back melted with exquisite gradation into burnished silver, and from nose to tail he glittered with an iridescence that would put mother-of-pearl to the blush. We marked the dorsal fin snug in its sheath, the pectorals folded to the side and almost invisible, the mighty tail. And in the moment of triumph we wondered if the law of the survival of the fittest had been vindicated.

Time - one hour and five minutes; weight $125 \frac{1}{2} \mathrm{lbs}$.

Upon the morning following we had three strikes, and lost three sets of hooks and many yards of line. The next day was a blank; the day after, we watched a four-and-a-half-hours' fight between a tuna and Col. Morehouse. The fish proved the victor, but mercifully spared the life of our friend. This famous struggle was chronicled at length in all the local papers. Then Sunday brought us rest and hope. Upon Monday morning at 3.55 we 


\section{Life and Sport on the Pacific Slope}

struck into two fish - simultaneously! I lost mine in five seconds, and with it nearly two hundred yards of line. My brother was more fortunate his fish put to sea; and Jim persuaded me to leave the boat and try trolling from the stern of the launch. For an hour and a half I trolled without a strike, then I rejoined my brother. His fish was still on, apparently as vigorous as ever. Jim recited the old, old story that is always new to a sportsman. The tuna had towed the boat some eight miles; he had played all the tricks; he had shown amazing strength, speed, and bottom; he must, in Jim's opinion, prove a giant of the giants - the largest that had ever been hooked!

For three hours and twenty-five minutes my brother fought that fish! At last, inch by inch, he neared the steel - a yellow-tail gaff, not three feet long. Jim leaned far over the gunwale.

"He's as big as a whale," he yelled.

Then I caught a glimpse of him, as he surfaced within a few feet of me. He was seven feet long at a conservative estimate, and thick in the shoulder as any prize-fighter. A-two-hundred-andfifty-pounder if he weighed an ounce!

Then, as the gaff flashed in the air, he turned and fled; the reel shrieked in mortal agony. Ye gods and fishes! Would that wild rush never end?

"He must have taken two hundred feet!" I gasped.

"Two hundred yards!" replied my brother as the monster paused; "neither more nor less."

The day before he had spliced a new two-hundred-yard line on to what was left of the old one. 
I could see the splice vibrating between sky and sea.

"He 'll come now," said Jim. "Reel in, sir."

The fish still tugged and strained - but feebly. My brother admitted frankly that he personally was " cooked." Very slowly the good winch did its work. Presently I saw the purple back, and once more Jim seized his gaff. Then - how can I describe the catastrophe? - even as Jim made his pass, as a who-whoop began to gurgle in my throat, as my brother's set features relaxed, as doubt became certainty, - the fish broke water. I heard the splash, saw the tail strike the line, and caught Jim's agonised groan, -

\section{"He's off!"}

There is an ancient story concerning a man who took a load of Dutch cheeses up a very steep hill. As the waggon reached the summit, the tail-board broke and all the cheeses rolled from the top of the hill to the bottom; but the teamster said never a word. A bystander sympathetically invited him to swear. "No," replied the man solemnly. "It's no use, friend; cussin' won't help me. I - I can't do the subject justice!"

My brother and I were stricken dumb.

Tuna may be caught off Catalina Island, which lies within three hours' travel of Los Angeles, from May to December; but they do not strike unless the flying-fish are in the neighbourhood. June is the best month. It is wise to troll as close as possible to the kelp, skirting the bays and inlets. The tuna, like the seals, drive the flying-fish into the bays and keep them there. Moreover, a tuna can 


\section{Life and Sport on the Pacific Slope}

be handled to much greater advantage in shallow water, provided - bien entendu - that he is steered clear of the kelp. If hooked in deep water, he may sound at once. If he does this, in the fulness of his strength, no cutty-hunk line can stop him.

As I write, a letter has just come from my friend, Professor Holder, who held the record of '98 with a fish that scaled 183 lbs. He tells me that he caught the first tuna of '99, upon the 26th of May. This fish tipped over the boat and was brought to gaff in forty minutes. Col. Morehouse of Pasadena, who caught the first tuna in '96, now holds the record with a fish of 251 lbs., caught in three hours and a half. A Mr. J. H. Woods, of Lima, Ohio, deserves honourable mention, having (with the assistance of his boatman) played a large tuna for fourteen hours and fifteen minutes!

The tackle to be used should be of the best. Hardy Bros. of Alnwick-on-Tweed, and Edwin Vom Hofe of New York may be trusted to furnish the stoutest rods and reels. In Florida, tarpon fishermen scorn to use line heavier than eighteen-ply; the tuna has not yet been captured with a cuttyhunk finer than twenty-one; twenty-four is the favourite. When your quarry sulks he must be lifted, or at least snubbed; a fine line under such a strain snaps like pack-thread. A sixteen-ounce rod (split bamboo) should be bound from the butt to within three feet of the tip. The broken rods, so far, have generally snapped within a foot of the reel. I understand that Mr. Hardy has built a double-cane tarpon-rod with steel core. With such a rod, binding, doubtless, is unnecessary. 


\section{Sea Fishing}

The king-salmon stands next to the tuna in my affections, and may be taken with rod and reel in a dozen different localities on the Pacific coast, but seldom south of Santa Barbara. Monterey bay is a famous hunting-ground. At Santa Cruz are found boatmen, tackle, bait, and in the season, dozens of enthusiastic fishermen. My brothers and I have caught numbers of these fine fish off Port Harford. They vary in size from eighteen to forty pounds. Sir Richard Musgrave, I believe, holds the record with a monster of seventy pounds, taken with rod and reel at the mouth of the Campbell River. A cast of this salmon can be seen in the museum at Victoria, and no less august a paper than the Spectator chronicled its capture.

The bait is a fresh sardine, or, failing that, a large spoon. The rod should be light, stiff, and not too short; the reel should hold not less than five hundred feet of fifteen-ply cutty-hunk line. The authorities disagree as to the use of a sinker, but no rule can be laid down. I use a light sinker, and instruct my boatman to pull slowly in and around the schools of sardines, herrings, and anchovies, upon which the salmon feed. Failing in these tactics, I have substituted a heavier sinker, and trolled below the schools of bait; the salmon have then bitten freely. Of their comings and goings knoweth no man with certainty. December, January, February, and March are the best months, but, like wapiti, they shift their quarters with exasperating swiftness. Instruct your boatman to wire you the news of their advent, and lose not a moment in taking the next train to the fishing-ground. 


\section{Life and Sport on the Pacific Slope}

I think sea salmon-fishing is especially to be commended because the fish visits this State during the dullest season of the year. (I speak, of course, from a sportsman's point of view.) And they bite freely during the day. Early rising is quite unnecessary. Moreover, the hills and vales of California are wearing spring's mantle; even in December the bleak, brown slopes of the coast range begin to glow with tender tints, and the turbulent trade-winds are raging elsewhere. Upon land and sea lies the promise of peace and plenty, and the charm of this Frühlingslied cannot be set down in printer's ink.

The salmon makes a game fight, but he must miss the ice-cold waters of his northern home. His first rush is not always the worst. Sometimes he comes like a lamb to the steel, but at sight of it sounds with the speed of a stone dropped into a well. $\mathrm{He}$ is a past-master in the art of hammering a line. In the clear waters of the bay where I fish you may see him, deep down, shaking his thoroughbred head and striking the line with his tail. As he nears the surface you mark the superb proportions that are his insignia of royalty. Light coruscates from his silvery scales as from a Golconda diamond. $\mathrm{He}$ looks what he is - a king.

I leave His Majesty with reluctance, and turn to my friend the yellow-tail, sometimes called the white salmon. To the salmon, however, he is not even of kin. He belongs, strangely enough, to the pompanos (these delicious fish are esteemed by epicures an extraordinary delicacy), to the carangidoe, and his particular style and title is Seriola dorsalis. Until quite recently this handsome fellow 


\section{Sea Fishing}

was not found north of Point Conception, but of late large catches have been made in Monterey Bay. I have caught them off Pismo wharf in San Luis Obispo County, but Catalina Island is their home. Here they may be taken with rod and reel for nine months in the year - from April to December, and taken by the score!

The yellow-tail is stronger and speedier than the salmon, but he has a plebeian love of kelp, and is tricky as any street Arab. No spoon with seductive shimmer will tempt the Beau Brummel of Catalina. He turns aside from smelt and sardine if they swim ever so slightly askew, and he seldom swallows tainted bait - unless cast to the void as chum, when he proves himself less particular than a turkey buzzard. If he disapproves the lure he is apt to rub himself contemptuously against it, with results that (to him) must prove amazing. Many foul-hooked fish are caught thus.

You troll for this dandy, sitting comfortably in a chair facing the stern sheets, and the boatman who knows his business will use plenty of chum and row around, not through, the schools of fish. At Catalina, James Gardner, Arnold Hotson, William Sarnow, Harry Elms, and Mexican Joe, have studied carefully the habits of the yellow-tail; a blank day with any of these men in the boat is almost impossible. Out of one school it is not uncommon to take half a dozen fish.

The wise man hugs the kelp forest, but keeps an eye to seaward, for the presence of a school of yellow-tail is not to be mistaken. As soon as the fish strikes, the boatman must pull from the shore, 


\section{Life and Sport on the Pacific Slope}

even at the risk of breaking the line. For this reason slightly stouter tackle than that used for salmon is necessary. The first rush is always magnificent, and the reel sings shrilly, high up in alt. I myself use a twelve-foot rod, light and flexible, that describes under pressure the most enchanting parabola. The rods sold as yellow-tail rods in San Francisco and Los Angeles would serve excellently well as gaff-handles, but they are poles, nothing more nor less, and most singularly illadapted to the uses to which they are put. They are so short and stiff that a fish smartly turning will snap a twenty-four ply line as if it were thread. I believe my rod was the longest ever seen upon Avalon beach, but many good sportsmen expressed approval of it. My brother used a light lance-wood rod, some nine feet long, which was inexpensive and effective. Yellow-tail tackle-rods, reels, lines, and hooks - can be bought in Avalon. No first-class articles, however, are kept in stock.

These fish vary greatly in weight, running from fifteen to sixty and even seventy pounds. We used eighteen-ply line, but fifteen, I am convinced, is the sportsman's size, and of this, five hundred feet are amply sufficient. After the first mad rush the fish generally heads toward the boat; you think he is off the hook, but are soon most agreeably undeceived. As a rule, he resorts immediately to sounding and sulking. Under firm pressure he will surface, and sound again, repeating these tactics till he has exhausted both himself and you. So savagely does he sound that most fishermen wear a specially constructed belt, an abdominal protector that holds 


\section{Sea Fishing}

securely the butt of the rod. I prefer, personally, to fish for yellow-tail as one must, willy-nilly, fish for tuna, - with the butt beneath my right knee, and firmly grasped there, and the point of the rod above the starboard quarter of the boat. The left. leg, over which the rod passes, can be used to advantage as a lever, and both hands can thus be devoted to the reel.

At times the yellow-tail may be taken at the Isthmus by casting from the shore. The water is shallow and free from kelp, and the fun fast and furious. Unfortunately, the Isthmus is fifteen miles from Avalon, and the prospects of sport are precarious. When the fishermen draw their seines the yellow-tail follow the small fry into the shallow water, driving them ashore, thus supplying the angler with an abundance of fresh bait. Unless you actually see your quarry, casting at the Isthmus is labour wasted.

In trolling for yellow-tail the bait should swim, not spin, at least thirty yards behind the boat. Authorities disagree upon the nice question of giving the fish the butt when he strikes. Tweedledum says "Sock it to him!" Tweedledee asserts that the handsome knave will hook himself more surely if not interfered with. Personally, I side with Tweedledum. Early in the season, certainly to the end of July, the best grounds are to be found between Jew-fish Point and Church Rocks. After the first of August the largest catches are made between Lone Point and the Isthmus. The amateur will be guided in such matters by the professional experience of his boatman. 


\section{Life and Sport on the Pacific Slope}

The sea-bass affords capital sport, but he is not to be taken at Catalina after the middle of July. Later he may be found farther north; as I write (August 11th) the waters of Port Harford Bay are swarming with these fish. They are caught in nets at almost all seasons of the year, but in different localities. At Catalina they begin to bite freely about the middle of April. You must troll for them with a big smelt as a lure, and a fifty-pounder will give you a hard fight. Yellow-tail tackle should be used, and a short rod. I emphasise this, because the sea-bass is a sounder and sulker, and must be pumped to the surface again and again. He combines in his handsome person the beauty of salmon and yellow-tail, possessing the silvery scales of the former and the golden iridescence of the latter. A certain coarseness mars his appearance; he lacks the quality of salmon, and sometimes he plays the poltroon and comes sluggishly to the gaff.

The albicore may be taken with rod and reel at Catalina throughout the year, but you cannot make certain of his capture at any time. He likes plenty of chum, and the best lure is a mackerel or a flyingfish. He is a tuna in parvo, and knows all the tricks of his tribe. In weight he ranges from forty to seventy pounds; he loves blue water and plenty of company; he is frolicsome as a kitten, strong as a tiger-cat, and a voracious glutton.

His first cousin, the bonito, worthily sustains the family traditions as a fighter and a dandy. $\mathrm{He}$ is no sulker, and taken with an eight-ounce rod and trout-tackle, affords glorious sport. His rushes to and fro are positively bewildering to the most ex- 


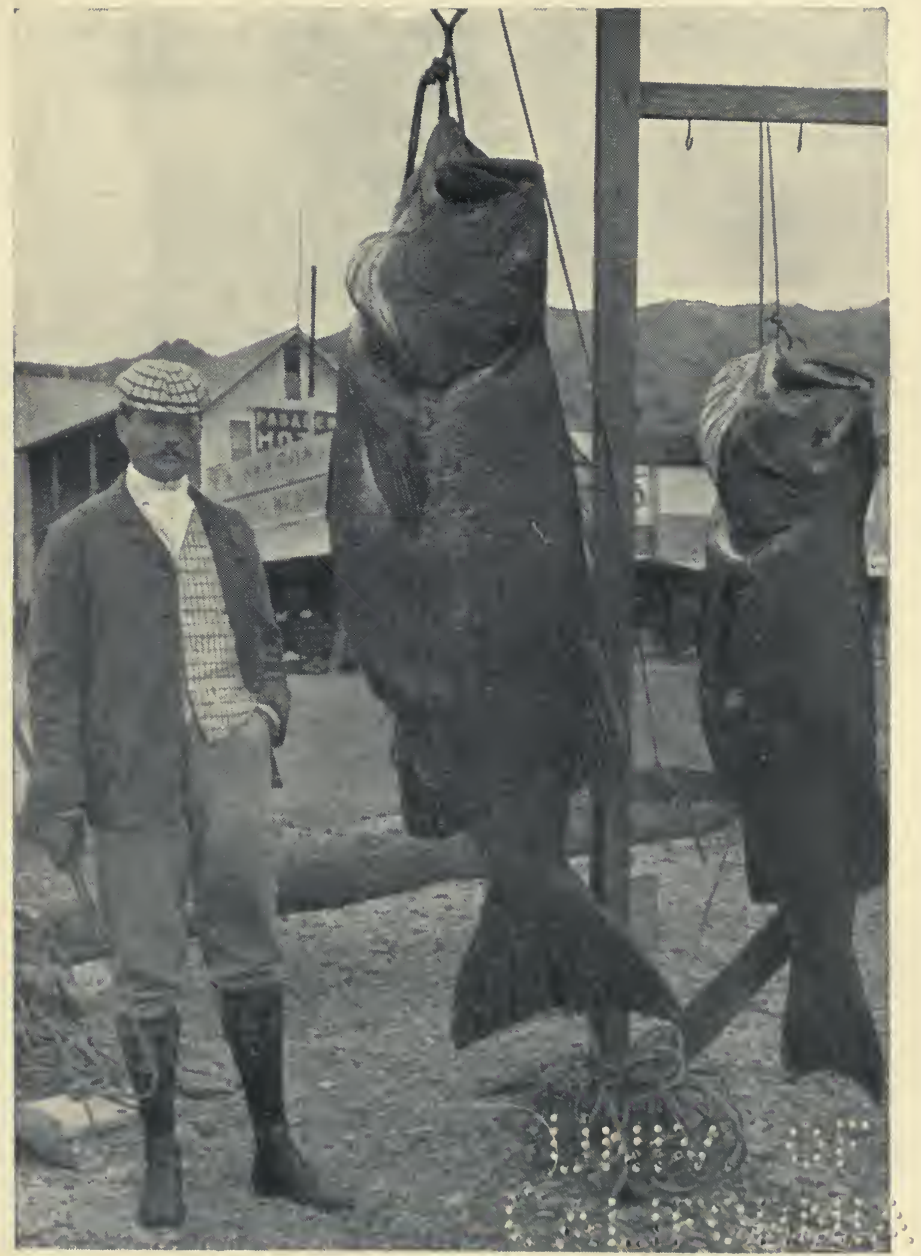

H. A. VACHELI. BLACK BASS-LAKGEST 320 LBS. 



\section{Sea Fishing}

perienced angler, and you are never certain of him till he strikes his own death knell upon the bottom of the boat. He may be hooked with jig, spoon, dead or live bait, and is to be found in the spring, summer, and autumn, between Point Conception and San Diego. My brothers and I have caught them at Port Harford and Pismo in August, September, October, and November.

These fish, like all mackerel, run in schools, and may be corralled, so to speak, by the abundant use of chum. I commend casting for them from the stern of a boat, and a small mackerel spinner is a deadly lure; if this fails, a sardine or anchovy may succeed.

I must emphasise, even ad nauseam, the necessity of employing light tackle when fishing for bonito. At Catalina, yellow-tail rods and lines are generally used, even by sportsmen. The fish are mercilessly reeled in, knocked on the head, and ultimately thrown away as refuse. Stout cutty-hunk line is about as well adapted to play an eight-pound fish, as an elephant gun would be to kill a quail on the wing. Bonito, moreover, should be salted and smoked; their bellies, delicately broiled, make a breakfast-dish fit to set before Lucullus.

To the halibut I am under obligations for many hours of excellent entertainment. $\mathrm{He}$ is not an aristocrat either in appearance or by birth, but he is a fighter, strong and speedy, and a heavy-weight withal. At Port Harford, during the late summer and fall, he may be taken with spoon, or dead bait. A heavy sinker must be used, as this fellow feeds on or near the bottom, and your boatman must be instructed to row slowly and hug the shore. The 


\section{Life and Sport on the Pacific Slope}

fish strikes vigorously, stampedes with terror when he feels the barb, but soon tires. My heaviest halibut scaled twenty-eight pounds; but fish weighing several hundred pounds are often taken with hand lines! They are found anywhere and everywhere, but seldom linger long in the same place. A friend of mine, who has studied their habits, says they bite most freely when the water is clear, and as the tide begins to flow. This has been our experience.

The barracuda comes last but one, and, like the bonito, merits better treatment than it receives at the hands of sportsmen. At Catalina, during the months of May, June, and July, these fish are slaughtered by the thousands. The power-launches, at times, are nothing else but shambles reeking with blood and slime; the. stands of the boatmen hang heavy with them every evening; and the importunate photographer drives a roaring trade.

The barracuda seldom weighs more than ten pounds, and affords fair sport if taken with light tackle. Any lure will serve, if he be biting, but he is an expert at disgorging. You will know him long before you see his lithe, sinuous body, by reason of his arrowy rushes and habit of shaking the hook. He seldom sounds, and never sulks, but easily tires. I have seen millions of these fish lying together, packed like sardines, side by side, motionless and deep down. At these times they never feed. Again I have seen them playing upon the surface of the water, lashing the summer seas into foam, too busily employed to make way for launch or row-boats, and falling, of course, an easy prey to both.

The black bass, Stereolepis gigas, is, I believe, not 
often caught north of Point Conception. He is a huge beast, as truly peasant as the tuna is prince, coarse, ugly, strong, and obstinate. He feeds in or near the kelp, and is a lover of carrion, particularly the red flesh of tuna or albicore. But the bonne bouche that he prefers to aught else is a live white fish or rock bass, carefully hooked below the dorsal fin. Mr. S. M. Beard, so I understand, was the first man to capture this monster with rod and reel. In a number of Outing, - which I regret to say I have been unable to procure, - Mr. Beard has described the fight, which lasted many hours. The fish weighed two hundred pounds.

Since then Mr. Rider has held the record of the largest fish taken with rod and reel (line not thicker than twenty-four ply), a record beaten last summer ('99) by Mr. T. S. Manning, who brought to gaff a bass of $330 \mathrm{lbs}$. Mr. Rider's fish weighed just three pounds less.

The two bass shown in the accompanying illustration were caught by me on a hand line. I fished for two days - eight hours a day - anchored off Silver Cañon, Catalina Island, in a ground-swell that exacted tribute from a boatman who had served a sixteen years' apprenticeship to Neptune; I held in hand my rod, with tuna reel and line attached, but had not a single strike. However, even with hand lines, black bass-fishing is exciting and not without a leaven of danger. Woe to the wight who fights the Jew-fish without gloves! I have seen scars that attest the Sheeny's strength and the angler's carelessness; a finger might easily be lost in such an encounter. 


\section{$33^{\circ}$ Life and Sport on the Pacific Slope}

This fellow approaches the bait with gutter-bred caution and suspicion, and bears it hence ready to drop it at an instant's notice. The fisherman feels but a gentle nibble, and allows the line to slip through his fingers. When six feet of it are gone, he stands up, and strikes! The massive hook must be driven home into a jaw that is hard and tough as sole leather. Then the monster flies kelpward, and must be turned if possible. He shows fair speed, but is a sluggard compared to the tuna. None the less he tugs and strains with right good will, putting your biceps and triceps to the proof. Give him slack and he escapes; no fish that swims can rid himself of a hook with greater ease than he. Finally, the steady strain tells upon his craven spirit, and he floats passively to his death. As he lies alongside a stringer is passed through his gills and out of his mouth and the ends made fast to the ring in the stern sheets of the boat. Then the boatman dispatches him with a single thrust of a keen knife. Dying, he manifests those vast muscular forces that properly exercised would have given him life and freedom. With his broad tail he churns the water into foam; with every roll of his gigantic body he threatens to overturn the boat. It is magnificent, but it is not sport!

My largest black bass weighed three hundred and twenty pounds.

The charm of sea-fishing is cumulative. Apart from the infinite variety of the sport itself, and above it, is the mysterious spell of ocean, of which so many men, from Ulysses to Louis Stevenson, 


\section{Sea Fishing}

have testified. And here, in southern California, where winds blow but blithely and storms are not, who can resist the sweet voice of the Pacific? To those who live upon the seaboard she calls night and day, in simple language that needs no interpreter. To the sportsman she promises much goodly entertainment and exercise; to women and children she warbles joyously of health and happiness; to the weary bread-winner she whispers - REST.

Yet how few of us give ear! 



\section{XVIII}

\section{FRESH WATER FISHING}





\section{XVIII}

\section{FRESH WATER FISHING}

WHEN many years ago an English officer was sent to Oregon - the Great Emerald Land - to report to the English Government upon its value and resources, he is said to have written these words: "Country not worth a d-n. Salmon won't take the fly!"

And this curse - for so an angler will regard it - still clings to the lovely streams and rivers of the north. The salmon refuse to rise to the fly. However, they snap at the glittering spoon and other baits, and once hooked, a salmon in condition will prove as game as the fish of Canada, Scotland, or Norway.

On the Pacific Slope there would seem to be five species of salmon : the king-salmon (the tyhee or quinnat), the dog-salmon, the blueback, the humpback, and the silver-salmon. Dr. Jordan, President of the Leland Stanford Junior University, and an international authority upon ichthyology, says: "Of these species the blueback predominates in the Fraser River and in the Yukon River, the silver-salmon and the humpback in Puget Sound, the king-salmon (or quinnat) in the Columbia and the Sacramento, and the silver-salmon in most of the streams along the coast. Only the quinnat has been noticed south of San Francisco. Of these species the king-salmon 


\section{$33^{6}$ Life and Sport on the Pacific Slope}

and blueback habitually 'run' in the spring, the others in the fall."

In the rivers near Mount Shasta, such as the Pitt River and the Macloud, the strength of the current and the numerous obstacles in the streams and along the banks add immensely to the sport. More than one angler has had to swim to save his fish, and if you happen to hook a ten-pounder in the rapids, you will be ready to swear that he is three times his actual weight. Accordingly, the sportsman who is unable to leave California would do well to make Sissons his headquarters. Sissons can be easily reached by train from San Francisco or Portland; but it is hardly necessary to add that if you want fishing extraordinary you must be prepared to camp out. There are very few places on the Pacific Slope where a man can enjoy first-class sport and sleep every night in a good hotel near the railroad.

Most men have their favourite spoon, but I prefer what is known (I think) as an Eel River spoon: of the size used for large steelhead. Sometimes the salmon only take a lure that looks as large as a sardine tin, but my brothers and I have had better fortune with the small article. It is impossible to lay down any rule. For the rest, ordinary salmon tackle is required. A Greenheart rod-about fourteen feet long (with several tips) - is more likely to stand rough usage than a split bamboo, and is easily spliced if broken. The simpler the reel, the better. Some American anglers use automatic reels, but for salmon spinning and trolling, the stout winch which was good enough for our 


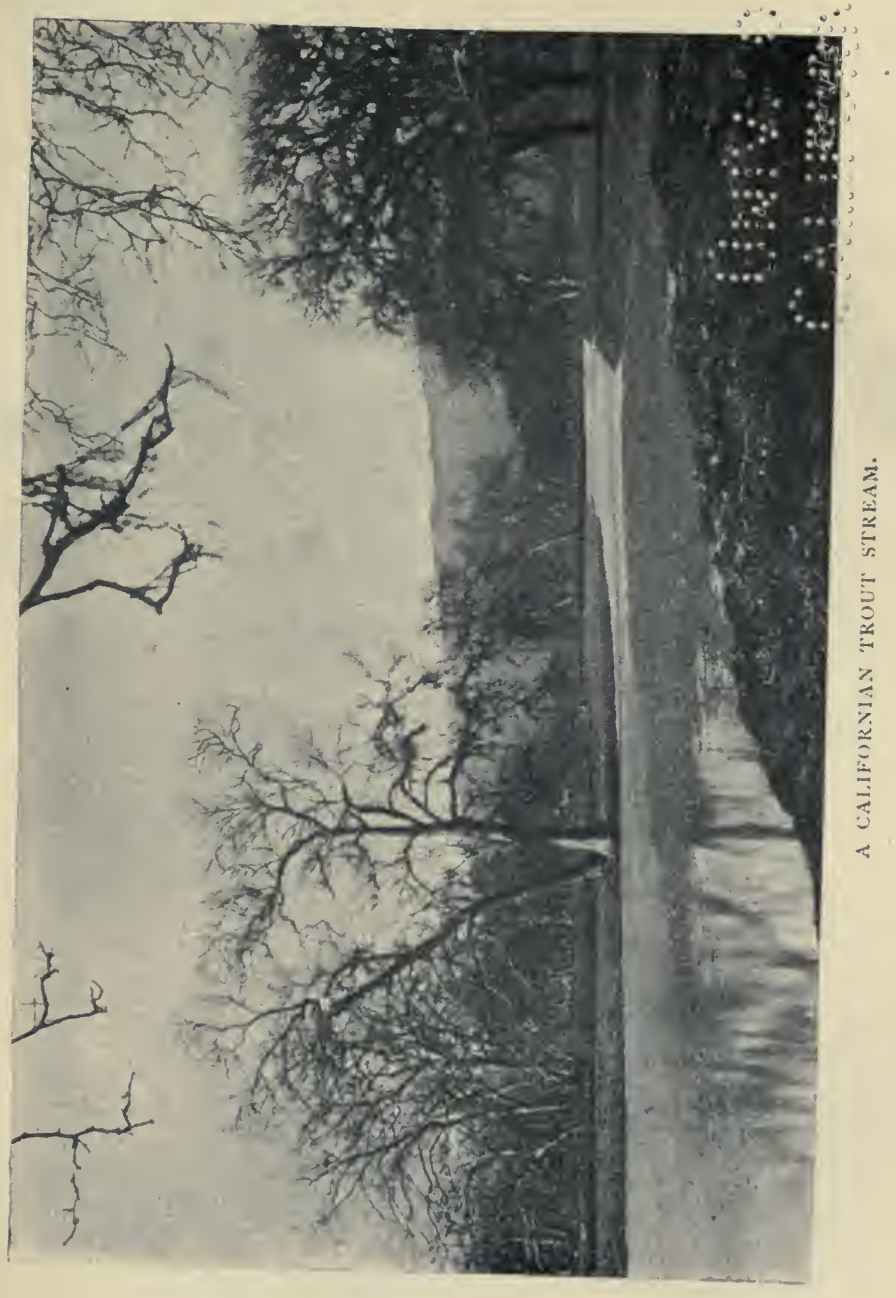





\section{Fresh Water Fishing}

grandfathers will prove in the end the most satisfactory. I should like to be able to say a kind word for American tackle, for the very best articles are superb, but there is an enormous quantity of trash on the market, and the middleman makes his profit out of the trash. Moreover the best is very expensive. I speak from bitter experience, when I urge the traveller to buy nothing but the best, and to buy that, if he can, in England, where he will pay just half what the crack Eastern makers will demand for their wares. Tackle, unfortunately, cannot be tested in a shop. I have bought flies and lines and traces which on the closest inspection seemed as good as they could be, and have had to throw them all away after a week's fishing! Most of the so-called waterproof lines "knuckle" after a few days' work!

If time is no object to the angler; I should advise him to travel straight to Victoria in Vancouver's Island, and on the rivers north of this pleasant town he will find, between the first of April and the end of October, sport so good that unless he is very keen he runs the risk of becoming glutted with it. He will learn on arrival that trout-fishing, not salmon-spinning, is the one topic of anglers, for trout take the fly, and the fishermen of Victoria hold the spoon in contempt.

No matter what river you choose, the fishing (nine times out of ten) must be done from a canoe. With a little practice two men can fish comfortably out of the same boat. You drop down stream till you come to a likely place, and then throw out a small anchor. The streams are wide, and the water 


\section{$33^{8}$ Life and Sport on the Pacific Slope}

very clear; so it is important to get out as much line as possible, casting your fly close under the bank. The rainbow trout average about a pound apiece, but five and six pounders are not infrequently caught. My brother and I would change ends every half-hour, for the man in the bow of the canoe fishes the left side and the man in the stern the right side of the river, and a change eases the muscles. As soon as a big fish is hooked, it will be prudent for the other fellow to reel in and lend a hand with the landing-net. A hint as to the use of the net. Many fine fish are lost at the supreme moment because the net is improperly used. The fish floating exhausted to the side of the boat is ladled out of the water as if he were a spoonful of porridge. If he has a kick left in him, he will resent this treatment, with a result that may be left to the imagination of the reader. And the more troubled the water, the more likely he is to break the line when he sees the fatal net. He should be tenderly coaxed half-way between the stem and stern of the canoe, and the net noiselessly held behind him. Then relax the strain, and in a jiffy he is in the toils. This rule is laid down, I suppose, in all the text-books, but I have seen it more honoured in the breach than the observance.

The fly of flies for these turbulent northern rivers is the Jock Scott, of the size used in Scotland for small grilse. Buy plenty of these, tied by the best man you know, and take others of the same size and colour, like the Silver Doctor, the Silver Grey, the Silver Wilkinson, the Blue Boyne, and that deadly insect, the Alexandra. These, I am aware, are all 


\section{Fresh Water Fishing}

salmon flies, but you can buy them of the smallest size, and in bright weather, on clear water, they ought to prove deadly. If a fish rises short, put on a smaller fly, and remember the Scotch maxim, "A bright fly on a bright day, and a dark fly on a dark day." Toward dusk, the Coachman, the Royal Coachman, the Coch-a-bondhu, and the Whitewing may be tried. The March Brown, the Red Spinner, and all the hackles are excellent. You will catch most of your trout early in the morning and after six in the evening, but there is generally a splendid rise in the middle of the day which seldom lasts more than three quarters of an hour.

Not the least part of the fun is poling up the rivers, and the passing of swift rapids exacts a nice adjustment of muscle and brain. The Siwash Indians are adepts at this work, and you will see one seemingly feeble old man poling a heavy bateau against a stream that you would pronounce irresistible. Those who can punt always fancy themselves at this game, till they have found out by trial the difference between rivers like the Thames and, let us say, the Cowichan. The man who poles uses his knee against the gunwale of the boat, and obtains thereby immense power. If, however, his pole should slip, the man's centre of gravity being outside the boat, it is almost impossible to avoid a bath. The secret of poling, like the secret of wrestling, is using the strength of what is opposing you. If the current strikes the canoe at a certain angle, a slight effort on the part of the poler will send the boat up stream. Suffer the stem to swing ever so slightly, and the canoe will 


\section{Life and Sport on the Pacific Slope}

be whirled round and round like a leaf in a mill race.

Sometimes you can wade, particularly in summer when the water is low. For this work you want wading-boots, not too light, and a fishing bag, not a basket, with two watertight compartments, one for the fish and the other for your fly-book. A good fisherman nearly always presents a workmanlike appearance, and details seemingly unimportant must not be neglected. A badly fitting coat, for instance, will cause intense annoyance and discomfort. You should buy a Norfolk jacket with what is called an expanding pleat, a coat which gives the arms full play. The inside pockets of this must be large and lined with waterproof which you can take out, wash, and dry.

Of the trout which swim in Pacific Slope rivers and streams, the largest is the steelhead (Salmo gairdneri), often miscalled the salmon trout, because the flesh is pink. These fish may be caught in most streams in the spring, and afford excellent sport, running in weight from four to fourteen pounds. They take the spoon more readily than the fly, but we have caught very many with the latter. My brother was fly-fishing one afternoon and hooking fish after fish, to the intense astonishment of a youth on the opposite bank, who was using the worm with no success. He (the youth) was not able to see the fly, but he concluded from my brother's actions that whipping the water was the only way to catch fish; accordingly he began thrashing the surface of the stream with worm, float and sinker, to my brother's great delight. $\mathrm{He}$ 


\section{Fresh Water Fishing}

worked away for nearly an hour and finally crossed the river and begged my brother to tell him why the fish were rising in one part of the stream and not in another.

Next to the steelhead in size comes the cutthroat trout, to be known at once by the deep orangecoloured blotches under the throat. After the cutthroat follows the glorious rainbow trout, which according to Dr. Jordan - may be distinguished from the young steelhead by the smaller scales of the latter, - there being in the rainbow trout about 130 in the lateral line, and in the steelhead about 150. Last but not least is the Dolly Varden, which, in salt water, grows to an immense size, and which swarms in the streams and inlets of the North.

These are the principal species, but there would seem to be many varieties. From the culinary point of view, trout vary in an extraordinary degree. Out of the same creel, filled with fish of the same species, caught in the same place, some prove delicious and others only middling. In Lake Cowichan we found a hideous parasite, something like a lamprey, which attaches itself to the big trout. The fish afflicted by this loathsome reptile were always thin and out of condition, and showed but poor sport. In the streams this parasite is washed off by the swiftly flowing water, but in the rivers we caught trout with the mark of the beast upon them.

Speaking of lake trout, I am inclined to believe that if you want to capture the monsters you must troll for them at a depth which demands the use 


\section{Life and Sport on the Pacific Slope}

of a heavy sinker; and the heavier the sinker the worse the sport. We caught some leviathans in Lake Cowichan, using immense spoons, but the fish taken on the surface with grilse flies were always small, - under two pounds. Fishing in the lake we invariably caught twice the weight of fish taken in the river, but we soon grew tired of the lake, whereas the beauty and charm of the river never palled. To those who are not prepared to camp out, no better place than the Cowichan Hotel can be found. It is within a few hours' travel of Victoria, and situated upon the edge of the lake. You can jump from your bed into eighteen feet of pellucid water! And the hotel is most comfortable. You are provided with boats and luncheons, and dinner is served when you return, no matter how late the hour may be. In most American hotels, if you miss the regular meals you must go without proper food, but across the border the tavernkeepers are more considerate. What man will leave a river when trout are rising freely? But it is hard indeed after a strenuous day with rod and pole, to return home to cold meats and a colder welcome.

Trout-fishing in California, particularly in southern California, and in smaller streams of Washington and Oregon, is tame sport. As a rule, the fish are very small, averaging about a quarter of a pound, and in many places may be caught by the sackful!

It is almost impossible to get reliable information about good trout-fishing in streams and rivers. The lake-fishing is another matter. I have found 


\section{Fresh Water Fishing}

it to be a rule without exception that if you insist upon first class sport, you must pay a stiff price for it. To reach rivers that are not, comparatively speaking, fished out, you must travel far and wide, and then - as with small game shooting - there is the problem of what to do with your fish. In the North, the Siwash Indian will smoke them for his own use in the winter, and if you go far afield, it will be necessary to take one or two of these fellows with you. They can be hired, according to their age and accomplishments, at a wage somewhere between fifteen and forty dollars a month.

You will find three rods, with extra tips, quite sufficient: one, as I have said a Greenheart, the other a split bamboo for light work, and a stout trolling-rod. You will do well to take a rifle with you, for sooner or later (particularly in the fall) you are sure to see a bear. Bruin loves fish, and when the salmon are running, he will stand on a sand bar and scoop them out of the water. Moreover, upon the banks of all the northern rivers berries grow in great and varied profusion, and Bruin is a glutton for fruit. Black-tail deer too are common, and if Fortune smiles upon you, it is possible that you may have a shot at a wapiti.

If you can sketch, your enjoyment will be doubled. The colour of this Far Northwest is enchanting. And the cool, lonely woods possess a fascination that some artist may learn to transfer to canvas. The great age of the moss-bearded pines and spruces and redwoods pricks the fancy. Beneath their fragrant boughs primal man still wanders. To the artist, these ancient groves are the sanctuary 


\section{Life and Sport on the Pacific Slope}

of the past, into which the pilgrim of to-day should pass reverently as into aisles hallowed by centuries. Through them roll the great rivers to the sea. Standing in the shade of the huge ferns, I have seen the canoes of the Indians glide by swiftly and in silence. The men at prow and helm are as graven images of bronze. A minute passes and they are gone - whither? But the pines and cedars remain.

Now and again you hear the mournful cry of the loon, the bird banshee of the lakes, - a cry so plaintive, so pitiful, that it would seem to be the sobbing protest of life against laws under which life has being. Or the silence is fractured by the crash of some falling tree, and you remember that a few miles away is a logging camp, and that the years of even the patriarchs are numbered.

To those who have lived in this Silent Land, and who are constrained to return to the noisy marketplaces of the world, there comes a nostalgia of the woods and streams, a yearning love that feeds upon the memory and is never satisfied with its food.

What message do these solitudes hold? What secret? And for whom will they break the silence of the centuries? Surely some Daniel will interpret for us the writing upon these shining walls. And the message, we may predict, will be strong and tender and true, - a gospel of purity and peace, of rest and of renunciation also.

May we live to read that message! 
APPENDICES 



\section{I}

\section{A FEW STATISTICS}

THESE statistics are taken for the most part from by the San Francisco "Chronicle." I am under obligations to Mr. M. H. De Young for permission to use his figures. It will be seen at a glance that the fruit industry in California has received at last the attention it deserves at the hands of the world. In the Annual Report of the California State Board of Trade written by General Chipman, the Chairman of the Industrial Resources of California, I find this significant paragraph, which I quote in full: "The year of 1898 was a year of drought in portions of the State, and it was a year of much injury from frost. It has been generally supposed that the fruit industries, as well as the cereals, suffered severely, and that there would be a large falling off in shipments. Let us examine the tables. They were made from the returns of the Transportation Companies, and represent actual shipments to points in other States. For the data as to shipments by rail, I beg to acknowledge my obligations to Mr. A. D. Shepard, General Freight Agent of the Southern Pacific Company, and to Mr. W. E. Bailey, Auditor of the Santa Fé System. The shipments by sea are compiled from the annual issue of the San Francisco 'Journal of Commerce.'

"In 1897 we sent away of fruit (including nuts), wine, brandy, and vegetables, by rail and by sea, 48,072 carloads (of ten tons each). In 1898 we sent away 56,149 carloads. The following table compactly shows the gain 


\section{8}

\section{Appendices}

and loss of each class carried into the table, expressed in carloads of ten tons each.

Table of Gains and Losses, 1897 and 1898 compared.

Carloads of 10 Tons each.

\begin{tabular}{|c|c|c|c|c|}
\hline Kinds. & 1897. & 1898. & Gain. & Loss. \\
\hline Green deciduous . & $7,235.0$ & $6,973.2$ & & 261.8 \\
\hline Citrus fruits . . & 9,854 & 18,06 & $8,211.2$ & $\ldots$ \\
\hline Dried fruits . . & $7,515.9$ & 7,666 . & 150.4 & $\ldots$ \\
\hline Raisins . . & 3,906 & 4,779 & 873.1 & $\ldots$ \\
\hline Nuts . . . & 580.8 & 581.6 & .8 & \\
\hline Canned fruits . & 7,346 & 5,22 & .. & $2,124.4$ \\
\hline Vegetables. . . & 4,734 & $3,847.0$ & & 888.6 \\
\hline Wines and brandy & $6,897.8$ & $9,014.0$ & $2,116.2$ & $\cdots$ \\
\hline Totals & $48,071.7$ & $56,149.6$ & $11,351.7$ & $3,274.8$ \\
\hline Net gain, carloads & $\ldots \ldots$ & & $8,076.9$ & \\
\hline
\end{tabular}

"Remembering the frost damage in certain localities and injury from drought, where water was not obtained for irrigation, this is certainly a most gratifying result. The increase in citrus fruit cannot fail to challenge notice. The best previous year for this fruit was 1895 , when we sent away 11,582 carloads. But 1898 exceeds that year by 6,476 carloads, and 1897 by 8,211 carloads. It is also gratifying to note that of 1898 shipments of oranges 589 carloads went from Northern California. Since we commenced to ship oranges from the north, the record stands : 1893, carloads, 4 ; 1896, carloads, 81 ; 1897, carloads, 286 ; and last year, 589. Considering that the first oranges to ripen come from the north, and go into home consumption largely, this is an encouraging showing.

"The increase in raisin shipments over 1897 was 873 carloads. The largest previous shipment of raisins was in 1894, being 4,695 carloads; the industry began to 


\section{Appendices}

decline after that year. I think its recovery is directly attributable to the placing of a protective tariff duty upon Zante currants (a competitor of raisins), towards the accomplishment of which this Board exerted a very considerable influence. To the present schedule of duties is due also a better feeling as to the citrus industry. The large increase in wines and brandy gives evidence of better times for the producer. The increase was about 30 per cent over 1897."

I now append a table showing the gains of ten years.

\begin{tabular}{|c|c|c|c|c|c|c|c|}
\hline & & & & & & 1888. & 1899. \\
\hline Dried prunes, & lbs. & - & - & & - & $8,050,000$ & $96,500,000$ \\
\hline Figs, & " & . & . & . & • & 175,000 & $2,000,000$ \\
\hline Raisins, & “ & . & . & . & . & $19,000,000$ & $66,000,000$ \\
\hline Peaches & 6 & . & . & . & . & $8,650,000$ & $8,000,000$ \\
\hline Apricots, & “6 & 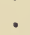 & . & & . & $3,250,000$ & $5,000,000$ \\
\hline Apples, & “ & 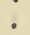 & . & & . & 550,000 & $5,000,000$ \\
\hline Pears, & “ & • & . & & . & 150,000 & $5,000,000$ \\
\hline Plums, & “ & . & . & . & . & 365,000 & $2,500,000$ \\
\hline Beet sugar & "6 & - & - & - & • & $4,280,000$ & $42,500,000$ \\
\hline Total . & . . & - & - & - & - & $44,470,000$ & $232,500,000$ \\
\hline
\end{tabular}

Of canned fruits put up in cans weighing two and a half pounds, and packed in cases containing two dozen cans, we find in 1888, 1,368,000 cases, and in $1899,2,900,000$ cases. Of fresh fruit sent East in 1895, there were 4,568 carloads against 6,469 carloads in 1899 . Of oranges, there were $1,325,000$ boxes exported in 1895 , against $3,654,000$ boxes in 1899. I cannot quote the figures for 1888 .

In looking over the above tables, it will be noted that the crop of apricots and peaches in 1899 was small. The crop of 1897 in apricots (dried fruits exported) was $30,000,000$, and the exported crop of dried peaches in the same year $27,150,000$. 


\section{Appendices}

Cereals.

\section{Our Wheat Crop.}

Our wheat crop for 1899 was about an average one. The acreage and yield since 1893 have been as follows, according to the estimate of our State Board of Agriculture :-

Acreage and Yield since 1893.

\begin{tabular}{c|c|c|c|c}
\hline Year. & Acreage. & Bushels. & Per Acre. & For U. S. \\
1893 & $2,875,307$ & $31,964,559$ & 11.1 & 11.4 \\
1894 & $2,587,568$ & $26,071,510$ & 10.0 & 13.2 \\
1895 & $2,033,938$ & $20,779,832$ & 10.2 & 13.7 \\
1896 & $2,423,585$ & $29,655,174$ & 12.2 & 12.4 \\
1897 & $2,665,943$ & $30,586,310$ & 11.4 & 11.4 \\
1898 & $203 \cdots$ & $12,404,166$ & $\ldots$ & $\ldots$ \\
1899 & $2,995,445$ & $30,833,333$ & 10.2 & $\ldots$ \\
\hline
\end{tabular}

The relative position of California as a wheat producer has been as follows for the past three years :-

Wheat Crop, 1897.

Bushels.

World . . . . . . . . . 2,269,352,000

United States . . . . . . . . 530,149,168

California . . . . . . . $32,394,020$

Wheat Crop, 1898.

Bushels.

World . . . . . . . 2, 2,907,000,000

United States . . . . . . . . $710,000,000$

California . . . . . . . . 12,404,166

Wheat Crop, 1899. (Estimated.)

Bushels.

World . . . . . . . 2, 2,540,000,000

United States . . . . . . . $717,300,000$

California . . . . . . . $30,833,333$ 


\section{Appendices}

From the foregoing we may infer that, roughly speaking, California usually produces about 6 per cent of the wheat crop of the United States and 1 per cent of the world's crop.

The value of the wheat crop of the State for the last three years, including the estimate of 1899 , has been as follows :-

\begin{tabular}{|c|c|c|c|c|c|c|}
\hline & er cent & & & & & $\$ 27,159,720$ \\
\hline 189 & “ & & . & . & & $6,670,000$ \\
\hline 1.05 & “ & & & , & & $19,425,000$ \\
\hline
\end{tabular}

The prices per bushel are 84 cents, 69 cents, and 63 cents for the respective years.

\section{The Barley Crop.}

Next to wheat the principal cereal crop of the State is barley, of which we export large quantities to Europe for brewing purposes. The requirements of barley for malting purposes are light colour, plump grain, and weight not less than forty-six pounds to the bushel. It must be clean and free from broken grains. The quality of our barley is such that it finds the highest favour with European brewers, and we always have an assured market at the highest prices for all the barley which we can produce that complies with brewing requirements. Barley is a comparatively small item of the grain exports of the United States, and of the total shipments California furnishes by far the greater part. In fact, the United States exports of barley fluctuate almost in a direct ratio with the size of the California crop. For example, in 1897, when California produced 26,309,325 bushels of barley, the exports from the United States were $11,237,077$ bushels (fiscal year 1898), while of the crop of 1898 , which in California amounted to but $11,413,043$ bushels, the exports from the United States fell to 
$2,267,403$ bushels. Since the harvesting of the crop of 1899 exports of barley from this State have rapidly increased, and, for the first time in the history of the State, our exports of barley have exceeded those of wheat, the comparative figures from the 1st of July to this writing being as follows:-

Barley and wheat exported since July 1, 1899 :

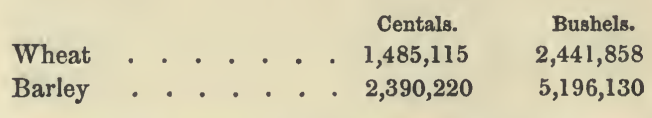

The value of the barley exported exceeds by more than $\$ 300,000$ the value of our exported wheat. It will also be noted that during the first six months of shipments of the crop of 1899, the exports of barley from California alone have been more than double those of the previous full fiscal year from the whole United States.

Our production of barley since 1893 has been as follows :-

California Barley Product-Bushels.

\begin{tabular}{r|r|r|c}
\hline Year. & Acreage. & Product. & Per Acre. \\
1893 & 702,321 & $16,780,952$ & 23.8 \\
1894 & 972,449 & $20,834,470$ & 21.4 \\
1895 & $1,071,998$ & $22,913,617$ & 21.4 \\
1896 & 918,384 & $19,837,094$ & 21.6 \\
1897 & $1,052,373$ & $26,309,325$ & 25.0 \\
1898 & $* 971,847$ & $11,413,043$ & $\cdots$ \\
1899 & $* 97,847$ & $20,782,608$ & 21.3 \\
\hline
\end{tabular}

* Estimated. No figures of acreage of 1898.

Prices of barley are materially lower than last year, when the great deficiency in our crop raised the prices for feeding to a figure only limited by the price of imported maize. A price of $\$ 1.25$ per cental would perhaps 


\section{Appendices}

be a fair rate at which to estimate the value of the barley crop of 1898 , and 85 cents is perhaps a fair estimate of the value of that of 1899 ; upon this basis the crop of 1898 was worth $\$ 6,562,500$, and that of 1899 , $\$ 8,075,000$.

\section{Corn and Oat Crops.}

There are no reliable statistics of the corn and oat crops of the State. The State Board of Agriculture collects the data of acreage of all cereal crops as reported by the County Assessors, and upon the best information attainable estimates the yield per acre, and from these computes the total crop. The Secretary of the Board does not pretend that these figures are reliable, but only that they are the best approximations that can be made with the means supplied by the State. They are published only biennially, and this is not the year for their publication. There are no commercial estimates, although "guesses" are sometimes made. I am therefore only able to reproduce the figures given last year, which are as follows :-

Crops of Corn and Oats.

\begin{tabular}{|c|c|c|c|c|c|c|}
\hline \multirow{2}{*}{ Year. } & \multicolumn{3}{|c|}{ Corn. } & \multicolumn{3}{|c|}{ Oats. } \\
\hline & Acres. & Bushels. & Per Acre. & Acres. & Bushels. & Per Acre. \\
\hline 1893 & 71,676 & $2,319,257$ & 32.3 & 61,039 & $1,406,350$ & 23.0 \\
\hline 1894 & 98,011 & $2,613,516$ & 26.6 & 120,229 & $3,384,007$ & 21.4 \\
\hline 1895 & 93,945 & $2,556,500$ & 27.2 & 111,367 & $3,160,661$ & 27.4 \\
\hline 1896 & 85,531 & $2,602,730$ & 30.4 & 116,527 & $3,433,920$ & 30.0 \\
\hline 1897 & 81,264 & $2,753,000$ & 33.7 & 122,253 & $3,670,500$ & 23.0 \\
\hline
\end{tabular}

Oats are not considered a profitable crop in California, except in the moist lands.

It will be noted above that the yield in bushels of wheat 
per acre, while it compares favourably with the yield per acre in other States of the Union (being about eleven bushels per acre), is less than one-third of what is obtained in England, and one-fourth of what is harvested per acre in Denmark. This is significant. American farmers do not, as a rule, prepare the ground properly; they use little guano, and summer-fallowing is the exception rather than the rule. Those who have given this important subject the attention it deserves, are of opinion that improved methods will enhance enormously the average yield of wheat per acre throughout the United States.

WINE.

\begin{tabular}{|c|c|c|c|c|c|}
\hline \multirow{2}{*}{\multicolumn{2}{|c|}{ Wine in gallons }} & \multirow{2}{*}{\multicolumn{2}{|c|}{$\begin{array}{c}1888 . \\
7,305,000\end{array}$}} & & \\
\hline & & & & & $\begin{array}{c}1899 \\
13,150,000\end{array}$ \\
\hline \multicolumn{5}{|c|}{ Miscellaneous. } & \\
\hline $\begin{array}{c}1899 \\
“\end{array}$ & $\begin{array}{l}\text { Wool } \\
\text { Hops }\end{array}$ & Crop & $\begin{array}{r}29,500,000 \\
8,325,000\end{array}$ & lbs. & \\
\hline $\begin{array}{c}1898 \\
\text { “ }\end{array}$ & $\begin{array}{l}\text { Butter } \\
\text { Cheese }\end{array}$ & & $\begin{array}{r}23,691,321 \\
5,148,372\end{array}$ & “ $(\mathrm{N}$ & returns for '99. \\
\hline
\end{tabular}

I regret that I am unable to obtain reliable figures in regard to other industries : cattle, hogs, horses, the bean crop, the olive crop, the amount of honey, etc.; but the returns from the lumber industry obtained for the first time are not without interest. The commercial woods of California are redwood, sugar pine, yellow pine, spruce, cedar, and fir. The returns show the output for 1898 in thousand feet.

Redwood. Sugar Pine. Yellow Pine. Spruce. Ceedr. Fir.

\begin{tabular}{|c|c|c|}
\hline 42,176 & 180,454 & 22,688 \\
\hline Total Redwood & & $276,451,596$ \\
\hline Total all others & & $327,565,171$ \\
\hline Total all kinds & . & $604,016,767$ \\
\hline
\end{tabular}




\section{Appendices}

\section{THE MINERAL PRODUCTIONS OF CALIFORNIA FOR}

\section{SEVEN YEARS.}

Compiled by Charles G. Yale, Statistician.

Under the direction of A. S. Cooper, State Mineralogist.

\begin{tabular}{|c|c|c|c|c|c|c|}
\hline & \multicolumn{2}{|c|}{1891.} & \multicolumn{2}{|c|}{1892.} & \multicolumn{2}{|c|}{1893.} \\
\hline & Quantity. & Value. & Quantity. & Value. & Quantity. & Value. \\
\hline Antimony, tons. . & none & none & none & none. & 50 & $\$ 2,250$ \\
\hline Asbestos, tons : & 66 & $\$ 3,960$ & & $\$ 1,830$ & 50 & 2,500 \\
\hline Asphalt, tons & 4,000 & 40,000 & 7,550 & 75,500 & 950 & 161,250 \\
\hline Bituminous rock, tons & 39,962 & 154,164 & 24,000 & 72,000 & 32,000 & 192,036 \\
\hline Borax, pounds . . & $8,533,337$ & 640,000 & $11,050,495$ & 838,787 & $7,910,563$ & 593,292 \\
\hline Cement, barrels . & 5,000 & 15,000 & 5,000 & 15,000 & none & none \\
\hline Chrome, tons . & 1,372 & 20,580 & 1,500 & 22,500 & 3,319 & 49,785 \\
\hline Clay (brick), M. . . & - & - & - & - & 103,900 & 801,750 \\
\hline Clay (pottery), tons & 100,000 & 50,000 & 100,000 & 50,000 & 24,855 & 67,284 \\
\hline Coal, tons . & 93,301 & 204,902 & 85,178 & 209,711 & 72,603 & 167,555 \\
\hline Copper, pounds. . & $3,397,455$ & 424,675 & $2,980,944$ & 342,808 & 239,682 & 21,571 \\
\hline Gold . . . . & - & $12,728,869$ & - & $12,571,900$ & - & $12,422,811$ \\
\hline Granite . . . & - & $1,300,000$ & - & $1,000,000$ & - & 628,272 \\
\hline Gypsum, tons · . & 2,000 & 20,000 & 2,000 & 20,000 & 1,620 & 14,280 \\
\hline Infusorial earth, tons & none & none & none & none & 50 & 2,000 \\
\hline Iron ore, tons & - & - & - & - & 250 & 2,000 \\
\hline Lead, tons & 570 & - 49,020 & 680 & 54,400 & 333 & 24,975 \\
\hline Limestone and Lime & - & 300,000 & - & 300,000 & - & 301,276 \\
\hline Macadam, cu. yds. & - & - & - & - & 271,500 & 256,875 \\
\hline Magnesite, tons. . & 1,500 & 15,000 & 1,500 & 15,000 & 1,093 & 10,930 \\
\hline Manganese, tons . & 705 & 3,830 & 300 & 3,000 & 270 & 4,050 \\
\hline Marble . : . & - & 100,000 & - & 115,000 & - & 40,000 \\
\hline Mineral paint, tons & 22 & 880 & 25 & 750 & 590 & 26,795 \\
\hline Mineral water, gals. & 334,553 & 135,959 & 331,875 & 162,019 & 383,179 & 190,667 \\
\hline Natural gas . & - & 30,000 & - & 55,000 & - & 68,500 \\
\hline Onyx and Travertine & - & 2,400 & - & 1,800 & - & 27,000 \\
\hline $\begin{array}{c}\text { Petroleum, barrels } \\
\text { of } 421 \text { gals. }\end{array}$ & 323,600 & 401,264 & 385,049 & 561,333 & 470,179 & 608,092 \\
\hline Platinum, ozs. & 100 & 500 & 80 & 440 & 75 & 517 \\
\hline $\begin{array}{r}\text { Quicksilver, flasks } \\
\text { of } 76 \frac{1}{2} \mathrm{lbs} .\end{array}$ & 22,904 & $1,036,386$ & 27,993 & $1,139,600$ & 30,164 & $1,108,527$ \\
\hline Rubble, tons. . & - & $\overline{0}$ & - & $\overline{-100}$ & 99,600 & 199,200 \\
\hline Salt, tons . . . & 20,904 & 90,303 & 23,570 & 104,788 & 50,500 & 213,000 \\
\hline Sandstone . . ' & - & 100,009 & 一 & 50,000 & - & 26,314 \\
\hline $\begin{array}{l}\text { Serpentine, sup. ft. } \\
\text { Silver }\end{array}$ & $\overline{-}$ & $\overline{953,157}$ & - & $\overline{463}, 602$ & $\overline{-}$ & 537.157 \\
\hline $\begin{array}{l}\text { Silver } \\
\text { Slate, squares : }\end{array}$ & $\overline{4}, 000$ & $\begin{array}{r}953,157 \\
24,000\end{array}$ & $\overline{3}, 500$ & $\begin{array}{r}463,602 \\
21,000\end{array}$ & $\overline{3}, 000$ & $\begin{array}{r}537,157 \\
21,000\end{array}$ \\
\hline Soapstone, tons . . & - & - & - & - & 400 & 17,750 \\
\hline Soda, tons. . . & $\overline{-}$ & $\overline{0}$ & - & - & - & - \\
\hline Tin, pounds . . & 125,289 & 27,564 & 162,000 & 32,400 & - & - \\
\hline Total . . . & & $\$ 18,872,413$ & & $\$ 18,300,168$ & & $\$ 8,811,261$ \\
\hline
\end{tabular}


THE MINERAL PRODUCTIONS OF CALIFORNIA FOR SEVEN YEARS. (Continued.)

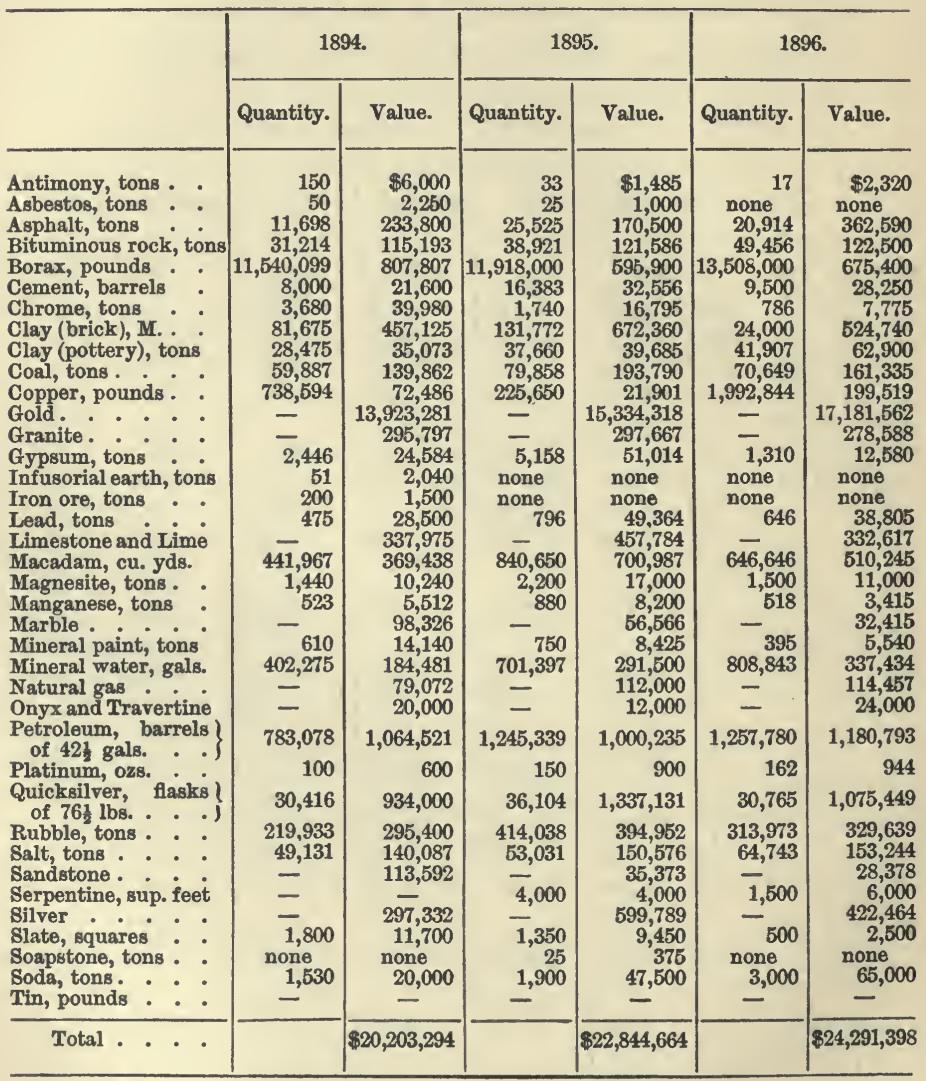




\section{Appendices}

THE MINERAL PRODUCTIONS OF CALIFORNIA FOR SEVEN YEARS. (Continued.)

\begin{tabular}{|c|c|c|c|c|c|c|c|c|}
\hline & & & & & & & \multicolumn{2}{|c|}{1897.} \\
\hline & & & & & & & Quantity. & Value. \\
\hline Antimony, tons & . & & & & & & 25 & $\$ 3,500$ \\
\hline Asphalt, tons. & . & . & . & . & . & . & 22,697 & 404,350 \\
\hline Bituminous rock, $t$ & ton & & . & . & . & $\dot{.}$ & 45,470 & 128,173 \\
\hline Borax, tons . & . & . & . & . & . & . & 8,000 & $1,080,000$ \\
\hline Cement, barrels & $\dot{0}$ & . & . & . & . & . & 18,000 & 66,000 \\
\hline Clay (brick), M. & $\dot{.}$ & . & : & . & . & . & 97,468 & 563,240 \\
\hline Clay (pottery), ton & ns & . & . & . & . & . & 24,592 & 30,290 \\
\hline Coal, tons & . & . & . & . & . & . & 87,449 & 196,255 \\
\hline Copper, pounds. & . & . & . & . & . & . & $13,638,626$ & $1,540,666$ \\
\hline Gold . . . & . & . & - & . & . & . & - & $15,871,401$ \\
\hline Granite, cu. ft. . & . & . & . & . & . & . & 339,288 & 188,024 \\
\hline Gypsum, tons & . & . & . & . & - & . & 2,200 & 19,250 \\
\hline Infusorial earth, tc & tons & & . & 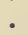 & . & . & 5 & 200 \\
\hline Lead, pounds & . & . & . & . & . & . & 596,000 & 20,264 \\
\hline Lime, barrels . & - & . & . & . & . & . & 287,800 & 252,900 \\
\hline Limestone, tons & . & . & . & . & . & . & 36,796 & 38,556 \\
\hline Macadam, tons. & . & & . & . & . & . & 487,911 & 313,087 \\
\hline Magnesite, tons & 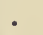 & . & - & . & - & . & 1,143 & 13,671 \\
\hline Manganese, tons & . & . & . & . & . & . & 504 & 4,080 \\
\hline Marble, cu. ft. & . & . & . & . & . & . & 4,102 & 7,280 \\
\hline Mineral paint, libs. & & . & . & . & $\dot{.}$ & . & $1,155,280$ & 8,165 \\
\hline Mineral waters, ga & als. & & & & - & . & $1,508,192$ & 345,363 \\
\hline Natural gas, cu. ft & & . & . & & . & . & $63,920,000$ & 62,657 \\
\hline Paving blocks, M. & & & & & & - & 1,711 & 35,235 \\
\hline Platinum, ozs. . & - & 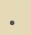 & • & & & . & 150 & 900 \\
\hline Petroleum, barrels & & & & . & . & . & $1,911,569$ & $1,918,269$ \\
\hline Quicksilver, flasks & s. & . & . & . & . & . & 26,648 & 993,445 \\
\hline Rubble, tons & . & 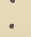 & : & : & . & i & 333,212 & 287,025 \\
\hline Salt, tons . & - & - & - & - & - & . & 67,851 & 157,520 \\
\hline Sandstone, cu. ft. & . & . & . & . & . & . & 77,000 & 24,086 \\
\hline Serpentine, cu. ft. & . & - & 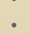 & 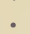 & 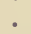 & . & 2,500 & 2,500 \\
\hline Silver . . . & . & . & & $\bullet$ & - & . & - & 452,789 \\
\hline Slate, squares & - & . & . & . & . & . & 400 & 2,800 \\
\hline Soda, tons . & . & - & . & - & - & - & 5,000 & 110,000 \\
\hline Total & - & • & & - & • & - & & $\$ 25,142,441$ \\
\hline
\end{tabular}


The Relative Position of California to Other States.

Population . . Twenty-second Wealth, per capita . . . First Size . . . . . . Second Savings deposits . . . Fourth Gold output . . . . . Second Wheat yield ..... Second Raisins . . . . . . First Hops . . . . . . Second Barley . . . . . . Second Hay . . . . . . . Fifth Lumber . . . . . Second Wines . . . . . . First

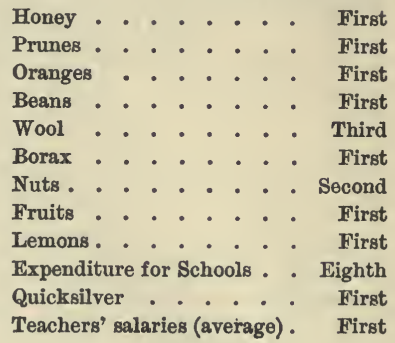

\section{Condition of California Banks.}

\begin{tabular}{|c|c|c|c|}
\hline RESOURCRS. & $\begin{array}{l}281 \text { Banks. } \\
1897 .\end{array}$ & $\begin{array}{l}285 \text { Banks. } \\
1898 .\end{array}$ & $\begin{array}{l}282 \text { Banks. } \\
1899 .\end{array}$ \\
\hline 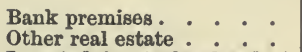 & $\begin{array}{l}\$ 7,174,93288 \\
15,130,61203\end{array}$ & $\begin{array}{l}\$ 7,105,03431 \\
17,594,32688\end{array}$ & $\begin{array}{l}\$ 6,865,42630 \\
18,334,10940\end{array}$ \\
\hline $\begin{array}{l}\text { Invested in stocks, bonds, } \\
\text { and warrants }\end{array}$ & $40,292,19419$ & $52,340,23714$ & $66,297,03154$ \\
\hline Loans on real estate & $116,794,72321$ & $111,283,35018$ & $107,104,39541$ \\
\hline $\begin{array}{l}\text { Loans on stocks, bonds, and } \\
\text { warrants }\end{array}$ & $18,458,98318$ & $19,041,11521$ & $20,631,89372$ \\
\hline $\begin{array}{l}\text { Loans on other securities } \\
\text { Loans on personal security } \\
\text { Money on hand } \\
\text { Due from banks and bankers } \\
\text { Other assets }\end{array}$ & \begin{tabular}{r|r|}
$4,449,314$ & 29 \\
$51,109,07130$ \\
$24,001,39301$ \\
$21,875,83236$ \\
$3,128,39917$
\end{tabular} & $\begin{array}{r}7,295,10559 \\
57,815,27176 \\
31,242,29676 \\
23,451,14801 \\
3,724,64574\end{array}$ & $\begin{array}{r}7,298,78031 \\
60,326,99784 \\
31,968,01603 \\
34,312,67836 \\
5,307,63911\end{array}$ \\
\hline Totals . . . . . & $\$ 302,415,45562$ & $\$ 330,892,53158$ & $\$ 358,446,96802$ \\
\hline \multicolumn{4}{|l|}{ LIABILITIES. } \\
\hline $\begin{array}{l}\text { Capital paid up } \\
\text { Reserve fund and profit } \\
\text { and loss }\end{array}$ & $\begin{array}{r}\$ 52,224,38185 \\
27,549,12339\end{array}$ & $\begin{array}{r}\$ 50,870,25821 \\
28,296,58414\end{array}$ & $\begin{array}{r}\$ 46,801,31862 \\
29,123,50478\end{array}$ \\
\hline Due depositors & $206,481,60045$ & $232,709,28416$ & $256,864,39547$ \\
\hline $\begin{array}{l}\text { State, city, and county } \\
\text { money }\end{array}$ & 100,54571 & 177,71829 & 491,47895 \\
\hline $\begin{array}{l}\text { Due banks and bankers } \\
\text { Other liabilities }\end{array}$ & $\begin{array}{l}9,292,57304 \\
6,767,23118\end{array}$ & $\begin{array}{r}12,380,73994 \\
6,457,94684\end{array}$ & $\begin{array}{l}14,044,91068 \\
11,121,35952\end{array}$ \\
\hline Totals & $\$ 302,415,45562$ & $\$ 330,892,53158$ & $\$ 358,446,96802$ \\
\hline
\end{tabular}




\section{Appendices}

\begin{tabular}{|c|c|c|}
\hline \multirow{4}{*}{ 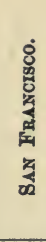 } & 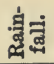 & 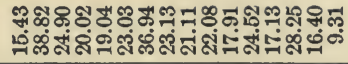 \\
\hline & 过 & 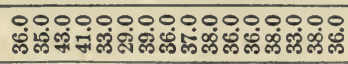 \\
\hline & 兰 & 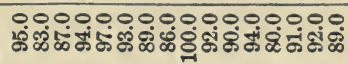 \\
\hline & ๕્ّ & 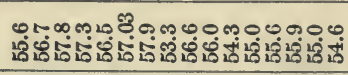 \\
\hline \multirow{4}{*}{ 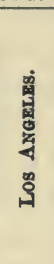 } & 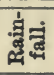 & 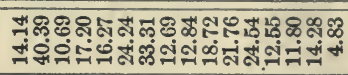 \\
\hline & 递 & 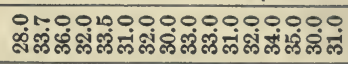 \\
\hline & 范 & 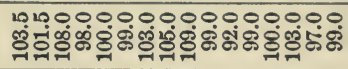 \\
\hline & ङ્ّ & 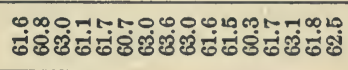 \\
\hline
\end{tabular}

\begin{tabular}{|c|c|c|}
\hline & \multirow[t]{3}{*}{ 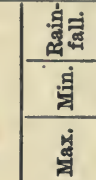 } & $|1|||$ | \\
\hline \multirow{2}{*}{ 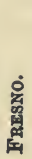 } & & 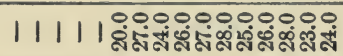 \\
\hline & & | | | | | \\
\hline
\end{tabular}

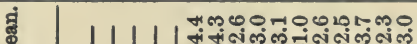

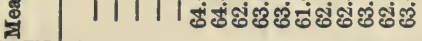

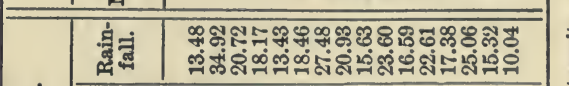

\begin{tabular}{|c|c|}
\hline 島 & 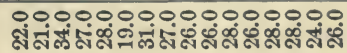 \\
\hline$\stackrel{\leftrightarrow}{\leftrightarrows}$ & 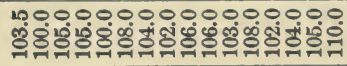 \\
\hline
\end{tabular}

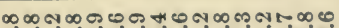
น์

\begin{tabular}{|c|c|c|}
\hline \multirow{4}{*}{ 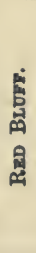 } & 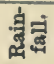 & 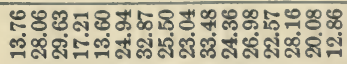 \\
\hline & 音 & 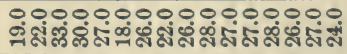 \\
\hline & हु & 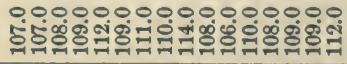 \\
\hline & 爮 & 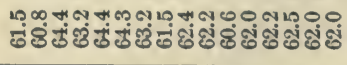 \\
\hline & & 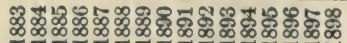 \\
\hline
\end{tabular}




\section{II}

\section{HORTICULTURE}

$7 \mathrm{HE}$ first questions for the would-be horticulturist to fornia he has the choice of hill or valley, of the seaboard or the interior, of climates which include the snows of Shasta in the north, and in the south the everlasting sunshine of San Diego. Of the many industries which challenge attention, it is sufficient to name the prune, the apricot, the peach, the olive, the apple and pear, and the citrus fruits : the lemon and orange.

The settler of course wants as much as he can get for his money; and I take for granted that he has, or will have, a wife and family. It behoves him, therefore, to consider not soil and climate alone, but those advantages, social, educational, and religious, lacking which life in a new country may prove not worth the living. A man of small means cannot afford to make mistakes; he has no capital to squander in costly experiments; and it is certain that he will make mistakes, that he will lose both time and money, unless he is prepared to profit by the experience and advice of others. On this account alone it is absolutely necessary to select a locality where the industry adopted has passed the experimental stage. Most young Englishmen, particularly those of the upper and upper-middle class, make their homes in places where Ishmael would starve. They try to combine two things which have no affinity for each other, viz., sport and money-making. Accordingly, they buy cheap land far 


\section{Appendices}

from civilisation, and discover too late that a little rough shooting is but a sorry equivalent for poverty, isolation, and wasted endeavours.

In horticulture the best soil, the best climate, the best advice are none too good for the man whose future happiness and prosperity are at stake. And so, if prune-growing be the industry chosen, I would urge the settler to buy land in Santa Clara county in preference to other counties, not because the prune will not thrive elsewhere, but because the prune output of this county is nearly three times greater than the entire product of the rest of America, and has a larger income from its fruit than any other county in the world. In like manner, the man who proposes to devote his energies and capital to the cultivation of oranges and lemons would be justified, in my opinion, in going south, to Orange, Riverside, Los Angeles, or San Bernardino counties, instead of north to Oroville; not because the Oroville oranges are in any respect inferior to those grown in the south, but because the south is par excellence the citrus fruit belt of the world. And let it be remembered that land (even in the heart of Santa Clara county) varies immensely : you will find thin, gravelly, unproductive soil side by side of the richest alluvial deposits.

The settler will ask - How can I, a stranger, tell the good from the bad? The answer is obvious, and lies on the tip of a thousand tongues. In a thickly settled community scores of persons may be found who will tell you the history of the piece of land in question. Find out what crops grew thereon, who owned it in the past, the nature of the subsoil, the depth to water, and so forth. It is inexpedient to accept blindly the testimony of one witness as to the merit or demerit of any piece of land, particularly if that witness be owner or agent; but Truth may be found, if you seek for her diligently. 


\section{Appendices}

Cheap land is nearly always poor land. And it will pay the horticulturist to give more than its value for the good rather than less for the bad. The men who have failed as fruit-growers bought, as a rule, cheap land, planted cheap trees, and employed cheap labour.

The highest priced land lies within a few miles of the large towns, but on that very account it offers irresistible advantages to the man of small means. While your trees are coming into bearing, you must support yourself by labour, or by the sale of berries and vegetables and eggs and poultry. In the big fruit-growing districts of California, men, women, and children can earn good wages picking, packing, and canning the fruit, while the merchants gladly buy the small products of the farm. In fine, a man of muscle and intelligence can make a handsome living upon a few acres near a large town, whereas he would probably starve upon a government claim of 160 acres five-and-twenty miles away.

Let it not be forgotten also that proximity to a town enables the horticulturist to sell his crop, either on the tree, or picked, or dried, without any tedious and perhaps expensive delays. More: if, for reasons unforeseen, he wishes to go elsewhere, his land near a town will sell quickly; in the hills, far from railroad and civilisation, a ranch, however good, may hang for years upon the owner's hands.

I submit some figures, but.I anticipate criticism of them, for I am aware of the amazing discrepancy between the experience of two men, let us say, living side by side, growing the same fruit, both successful, both entitled to speak with authority. My figures, collected at first hand, represent the mean between extravagance and a too rigorous economy.

Roughly speaking, the cost of setting out a vineyard, or an orchard of prunes, or peaches, apricots, apples, 


\section{Appendices}

olives, or cherries, is about the same. Citrus fruits are more expensive, as will be seen. And the profits are less variant than one might suppose, if an average be struck between the fat and lean years. The income should be at least ten per cent on the total investment, and often very much more.

Table showing prices of land per acre :-

Hill land for deciduous fruit . . . . . $\$ 30$ to $\$ 50$

Valley land for deciduous fruit . . . . . 100 to 200

Land, without water right, for citrus fruits . . 75 to 150

Land, with water right, for citrus fruits . . . 200 to 300

Land, with water right, and of the choicest qual-

ity, near Riverside . . . . . . . . . 300 to 400

Orchard in bearing of deciduous fruit . . . 300 to 1000

Orchard in bearing of citrus fruit . . . . 500 to 2000

These prices are for land in the choicest localities and situated near large towns. Some land companies in the State undertake to sell valley land, plant it to trees, deciduous or citrus, care for the same during three years, and then turn it over to the purchaser. Their figures average per acre $\$ 250$ for deciduous fruits, $\$ 300$ for olive trees, and $\$ 350$ for citrus fruits. I cannot commend this system of purchase. Corporations are said to have no conscience, and it is obvious that a company cannot give to these orchards the individual care they need. An orchard is like a kindergarten: each tree in it has its idiosyncrasies. If you do not wish to do your own work, it is possible to find in the districts $I$ have named reliable orchardists who will take charge of your property. I have made contracts with such men to plough, cultivate, prune, and supervise orchards of deciduous fruit at rates ranging from $\$ 8$ to $\$ 12$ per acre. These rates do not include, of course, the picking and drying of the fruit.

In Santa Clara county, an orchard of prunes or apricots 


\section{$364 \quad$ Appendices}

in full bearing should pay a net profit of $\$ 100$ per acre. Many pay more, very many pay far less. In and around Riverside and Orange are groves of ten acres which pay an annual income of $\$ 3,000$, but an average grove is not nearly so remunerative. At the same time, what man has done, man can do, and the horticulturist who fails iras generally nobody but himself to blame.

I can remember the time when wiseacres predicted that horticulture in California would be overdone. Since then the different fruit-growing industries have assumed a stupendous importance, and to-day California's orchards and vineyards bring in more money than the exports of her cereals. A glance at the statistics at the end of this appendix will satisfy any intelligent person that - as Horace Greeley predicted more than forty years ago "Fruit is destined to be the ultimate glory of California."

With new markets opening in the Philippines and all over the Far East, with an ever-increasing demand for her wares at home and abroad, with cheaper transportation, with co-operation on the part of producers, with better and more economic methods of handling her products, Horticulture in California holds out her arms to the world, not overdone, not played out, but young, fresh, and vigorous - another Atalanta, rejoicing because she has outstripped all competitors.

\section{A Short Catechism of Interest to Horticulturists.}

Q. What is the cost of planting one acre to prunes, peaches, apricots, or vines?

A. The prune is par excellence the fruit, for although an apricot or peach orchard costs no more to cultivate and care for, and the peach bears in three years, yet these fruits - while they command a higher average price than 


\section{Appendices}

the prune - are more subject to climatic changes. It is better to have an average crop of prunes every year than a bumper crop of apricots one season and a total failure the next. In the estimates submitted, cost of trees is not counted in. Prunes may be bought (the French is the leading variety) from 4 cts. up to 7 cts.; apricots, 8 cts. ; peaches, 8 cts. and 9 cts. Vine cuttings are worth 50 cts. to $\$ 2$ per thousand, and the cost of setting out a vineyard, with the vines from seven to eight feet apart, and cultivating the same till maturity, is about two-thirds that of setting out an orchard of prunes where the trees are one hundred to the acre.

The following estimate was taken from the books of a responsible prune-grower. It is the total cost of setting out and caring for a fifty-acre prune orchard, including every expense item : not omitting interest, computed at 9 per cent on original investment, and the cost of squirrel poison, etc. I believe that orchards can be set out and maintained for much less, but the man who bases his figures upon mine is within safe territory.

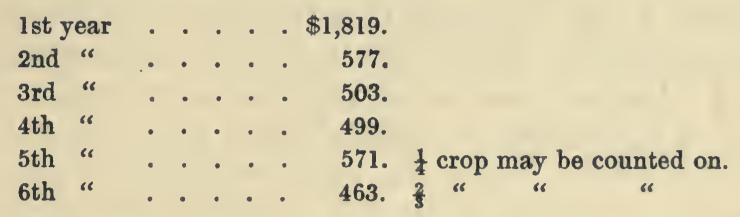

In the 7 th year the orchard comes into full bearing. Roughly speaking, it will be seen that the annual cost of an orchard per acre after the first year is about $\$ 10$.

The second estimate submitted is from an orchardist located upon our ranch. $\mathrm{He}$ is thoroughly responsible and capable. $\mathrm{He}$ is willing to agree with any intending purchaser to plant an orchard to prunes, to take care of it entirely for the sum of $\$ 20$ per acre for the first 
year, $\$ 11$ per acre for the second year, and for every succeeding year $\$ 10$, turning over to the owner the proceeds from fruit after the fourth year, less expenses of picking, drying, etc.

Q. In how many years do these trees bear remunerative crops?

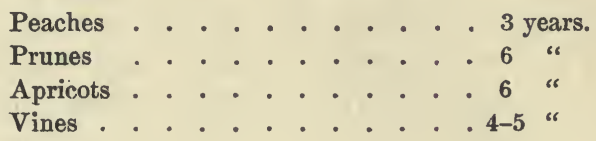

\section{Q. What is a remunerative crop?}

The value of a crop is determined by the laws of supply and demand," but generally speaking a small crop commands a big price, and a big crop a small price. The wise man must strike an average between the $\$ 2,000.00$ received for the crop of cherries from one acre, and the total failure from an acre of the same fruit near by. Roughly speaking a fair prune orchard in full bearing should net to the owner not less than $\$ 100$ per acre per annum, taking the average price of the green fruit at one cent per pound. To-day it is $1_{\overline{2}}$ and 2 cts. per pound.

Q. How may pests be combated?

It is a fact that in California means have been found to successfully destroy all pests that attack trees or vines. In the brief limits of a pamphlet it is impossible to describe at length the different methods of the leading horticulturists. Exact information can, however, be obtained. In no other part of the world have orchards and vineyards suffered so little as here; no danger need be apprehended from this source by the horticulturist who is willing to profit by the experience of others.

Q. What is the cost of lumber, rough and surfaced, and commodities? 


\section{Appendices}

Rough lumber . . . . \$1300 per thousand

Surfaced lumber . . . . 2100 " “

Flour . . . . . . . 400 " barrel

Butter . . . . . . . 25 " pound

Pork . . . . . . 10 " "

Bacon . . . . . 12 " “

Lard

09 “ "

Clothing and furniture are as cheap now as in the Eastern and mid-Western States, and a working man can feel comfortable in canvas overalls every day of the year.

Q. What employment can be found by orchardists and vineyardists?

Fruit-picking in the orchards and vineyards, and work in the canneries, dryers, packing establishments, and wineries give employment to thousands of men, wornen, and children. In the winter and spring there is work to be obtained by any man in possession of a stout team. None need be idle. Labour is worth from $\$ 20$ to $\$ 40$ with board. A good mechanic will work and supply his own board at $\$ 3$ to $\$ 5$ per diem. Cooks. command $\$ 25$ a month and board. Second girls $\$ 15$ a month. Girls from the East can always find employment at these figures. The supply of female help is far below the demand.

Q. Can money be made in the poultry business, with berries, melons, etc. ?

Yes; eggs and poultry always command a ready sale and a fair price. Turkeys, geese, ducks, and chickens do well throughout the year. The poultry yard of a thrifty orchardist should pay easily for the clothing of the family. Broilers average from $\$ 3$ to $\$ 5$ per dozen, eggs from 15 cts. to 30 cts. per dozen. Berries, melons, vegetables, etc., can easily be raised and sold or traded at local stores. California produces an enormous crop of berries, and every farmer ought to raise, between the trees 


\section{Appendices}

of his young orchard sufficient vegetables for his own use, and enough besides to pay his butcher's bill.

Q. Is it wise to purchase land with a small capital ?

The writer is honestly of the opinion that California. is one of the few places in the world where a man may start in business with a small capital. The State has been settled up and developed by persons who for the most part brought no money. While it is desirable to bring capital here, many men have been and are to-day making money without it.

Q. Is the present a good time to purchase - and why?

Most assuredly. The wise trader buys on the bumps and sells on the slumps. The stringency of the times a drought, - the first in twenty years, - and the general stagnation and depression following the disastrous boom of '86 and '87, have combined to place values below par, and according to expert authority a healthy reaction is now in order and almost inevitable. 


\section{III}

\section{VITICULTURE}

COOD wine, we are told, needs no bush, but Cali$U$ fornian wine is sold in England under a brand advertised extensively as the "Big Tree." Without in any sense depreciating this brand, it is proper to say that the best Californian wine is not sold in England at all. And it is not easy to obtain it in California. A friend of mine has in his cellars a certain Rhine wine some twenty years old, which he pronounces justly " a perfect dream;" but of this, I understand, there is hardly any left. Of the wines on the market, the best Burgundy of the SwissItalian colony, the sauternes of Livermore name, and the clarets made from the Lafite grapes (the Cabernet and Cabernet Franc) may be highly commended; while ports and sherries and other sweet wines made in Southern California find a fair market. So far the champagnes of the Pacific Slope have lacked the quality that distinguishes the French wine, but Mr. Paul Masson, of San José, is selling an article of uncommon merit; and he is enthusiastically of the opinion that champagne of the finest flavour, sparkle, and purity will in time be produced in his cellars.

Viticulture in California has steadily prospered in spite of disappointment, disease, and litigation. In early days a rough wine, "tinto," was expressed from the Mission grape by the Padres, and vines can still be found about the old adobe Missions more than a hundred years old, which still bear heavily. Mr. Nutting, writing on this subject, says :- 
"The oldest regular Mission vineyard known to me is about ten acres, planted in 1847 by the pioneer, Peter Lassen, on what is now the Stanford ranch at Vina, and it is more vigorous and prolific than some of the young vineyards of more popular varieties."

In 1880 more than 80 per cent of the 35,000 acres of vineyard in the State were of this quality-lacking variety; but to-day, out of 150,000 acres of vineyards, more than 60 per cent of the red wine is made from the Zinfandel grape. However, as the Secretary of the Italian-Swiss colony well points out, the Zinfandel can hardly be considered as one grade, because it varies according to the location and the soil in which it is grown.

The disappointment of which I have spoken overtook the men who, recognising the possibility of making wines of a high commercial standard, staked their time and money and special knowledge against the ignorance and prejudice of their fellow-citizens. The claret made from "quality" grapes came into competition with the rough red wines expressed from grapes that yielded five or more tons to the acre. The public generally were not able to discriminate between what was wine and what was not; in the East, those who did know the difference bought up the best wine at a price far below its value, and sold it under French labels, at an exorbitant profit, to the rich Californians. Many of the wine-makers were ruined, and the State as a wine-producing State was condemned, because only the worst wines were sold as Californian. This state of affairs was bad enough; worse followed. The phylloxera attacked the vineyards, and destroyed millions of vines. Then, when a brighter day seemed about to dawn, when resistant varieties were coming into bearing, when the public was just beginning to recognise the merits of the best Californian wine, when, in short, it seemed to the most conservative that the wine industry 


\section{Appendices}

was likely to become a stupendous factor in the prosperity of the State, a fresh disaster set its iron heel upon the vineyardists. The merchants, with that short-sighted policy which has always distinguished their relations with the producer, sought to monopolise the profits of wine-making, and succeeded for a season. Then cooperation on the part of the wine-makers brought about an armed peace, which terminated in open war. Finally, the claims of buyer and seller have been adjusted, and now - and not till now - wine-making would seem to have passed the experimental stage, and to have settled down into an organised industry which, properly managed, offers more than ordinary inducements to the prospective settler. I repeat if properly managed. Wine-making is an art, - an art, moreover, which would seem to be the peculiar possession of the Latin race. None the less, I am of opinion that the Englishman or American borrowing the experience of the Frenchman and Italian, and adding to it the results of his own observation and analysis, will beat the Latin in the end. Foreign wine-makers, I have noticed, cling like limpets to old world methods, but if there is one thing certain in regard to viticulture, it is that certain varieties of grapes vary enormously according to soil, climate, and elevation, and it is equally certain that the foreign wine-maker in California does not sufficiently take these variations into account.

Wine-making, however, requires not only experience, but a large working capital. The prospective viticulturist will do well, therefore, to confine his attention to growing grapes and selling them to the wineries. He can rely upon a price varying according to the season from $\$ 9$ to $\$ 12$ per ton. If he raises two and a half tons to the acre, his gross profits will lie between $\$ 22.50$ and $\$ 30$ per acre. Deducting 50 per cent for working expenses, interest on capital invested, etc., the net profit should 
average, year in and year out, not less than $\$ 13$ an acre, - a fair return from land that may be bought from $\$ 25$ to $\$ 45$ per acre. And it must be remembered that a vineyard is a permanent investment, and exacts less care and attention than a prune orchard or an orange grove. It is absolutely necessary to make no mistakes at first, either in the choice of your land, the buying of your cuttings, and the cultivation of the vineyard during the first five years.

I cannot do better than conclude these few remarks on wine and wine grapes with a clipping from an article which appeared some few months ago in the San Francisco "Chronicle:" -

- "Californian wine can compete with its European rivals, and, as to quality and price, to the great advantage of this State. The only drawback is the roundabout means of transportation. Californian wines have to be sent from here to New York, thence to England, and from there to the South American countries, becanse there is no direct line running either from this port or from the East. But it looks as if this hiatus would soon be a thing of the past. Several projects are maturing which promise the establishment of lines of steamers from New Orleans and New York to those South American republics which can be counted upon to consume a large proportion of the wine produced in California. The completion of the Nicaragua canal would also give us the required outlet, and of itself would go far toward solving the problem that has so long troubled those in the wine trade of securing markets for the wines grown in this State. ${ }^{1}$ Meanwhile domestic consumption is increasing, slowly, it is true, but yet it is growing, until now $20,000,000$ gallons of our dry wines are drank in the United States, and a trade is springing up with England, Belgium, Switzerland, and Germany which promises to attain considerable proportions.

1 The Panama Canal is now in the possession of New York capitalists. 


\section{Appendices}

Inquiries as to the handling of California wines are being received by San Francisco dealers that show that if the American tariff be placed in operation in the West Indies a large trade can be expected to be built up in Cuba and Porto Rico, where the middle and upper classes are accustomed to drinking Spanish and French productions, and will welcome the pure and low-priced vintages of California. In time, and if the trade be pushed, the Philippines will take off our hands millions of gallons of our low-grade wines, and it has been suggested that if the Government of the United States would place wine on its ration list so that it might be mixed with the unhealthful water of the tropics, the lives of many of the troops whom it will be necessary to maintain in the Philippines and the Antilles would be saved, and at the same time the vinicultural industry of California would be greatly benefited. Taking all these possibilities and probabilities into consideration, our annual average production of 20,000,000 gallons of dry wines should be as a drop in the bucket, and the time should not be far distant when every hillside in California should be set out in vines, and the amount of wine produced for home consumption and for export to our new territories and to other markets which stand ready to receive them, should rival that of the famed countries of Southern Europe."

\section{RAIsins.}

California produces as fine a raisin as that of Malaga, and one that keeps much better and is far cleaner. I have not lived in Fresno, which is the chief raisin district (it has about 35,000 acres in Muscat grapes, about three-fourths of California's raisin acreage), but I know from reliable sources that raisin-growing is a pleasant and profitable occupation, and that the industry was never more prosperous than it is at the present moment. The crop for 1899 was $66,000,000$ pounds (not counting the raisins consumed in the State), an increase in one decade of nearly 50,000,000 pounds : a result which must challenge the serious attention of the would-be vineyardist. 
A raisin vineyard bears well in four years from planting, and the fruit is dried in small trays by the sun alone. Each tray makes about seven pounds of raisins, and as there is no dew in raisin-growing districts, the grapes dry by night as well as by day. Experience alone tells the vineyardist when the raisin is sufficiently dried, but the methods are simple and inexpensive. A seeding-machine has been lately invented which extracts all seeds and turns out a raisin fit for a pudding. The inventor has certainly earned the undying gratitude of the busy housewife. Bare land can be bought at prices ranging from $\$ 50$ to $\$ 200$ an acre, and an acre in bearing ought to average year in and year out one ton of raisins. I learn with pleasure that the raisin-growers of Fresno, after a year's experience, have renewed their organisation for two years. Co-operation on the part of small farmers, fruit-raisers, and vineyardists is essential to their prosperity.

It is almost superfluous to add that no man who is intending to grow raisins should fail to visit Fresno, where he will learn more in a week than he could glean from fifty books on the subject. Fresno is now enjoying somewhat of a boom, owing to the flourishing condition of the Coalinga Oil fields. 


\section{IV}

\section{BEET CULTURE}

T Beet Culture California retains her leadership in 1 factory capacity and output of beet sugar, and seems likely to do so. The factories in California have a daily capacity of 8,500 tons of beets, while all the other factories in the Union combined average 8,300 tons. The sugar beet is raised in and around the following localities : Alvarado, Watsonville, Chino, Los Alamitos, Crockett, Spreckels, Oxnard, and Santa Maria.

The statement of the cost of raising beets and the profits derived therefrom is taken from the books of a beet farm near San Juan, and is quoted by Mr. Claus Spreckels, the father of Beet Culture in California.

It will be noted that in the case quoted above the land was rented. This land as a rule belongs to the owners of the factories, and so far the contract system of leasing land to farmers has worked well. Under the contract system the farmer has the assurance that he will get his money promptly at an agreed price upon the delivery of his product. He has also the advantage of the factory's expert advice upon all questions relating to the culture and harvesting of the beet. On the other hand, the farmer who owns his own land makes a larger profit, and consequently takes greater risks. Time - as General Chipman has well pointed out - will settle the present difference of opinion as to whether the farmer should be paid on the basis of the richness of the beet, or by the ton regardless of its purity or the sugar it contains. 


\section{Appendices}

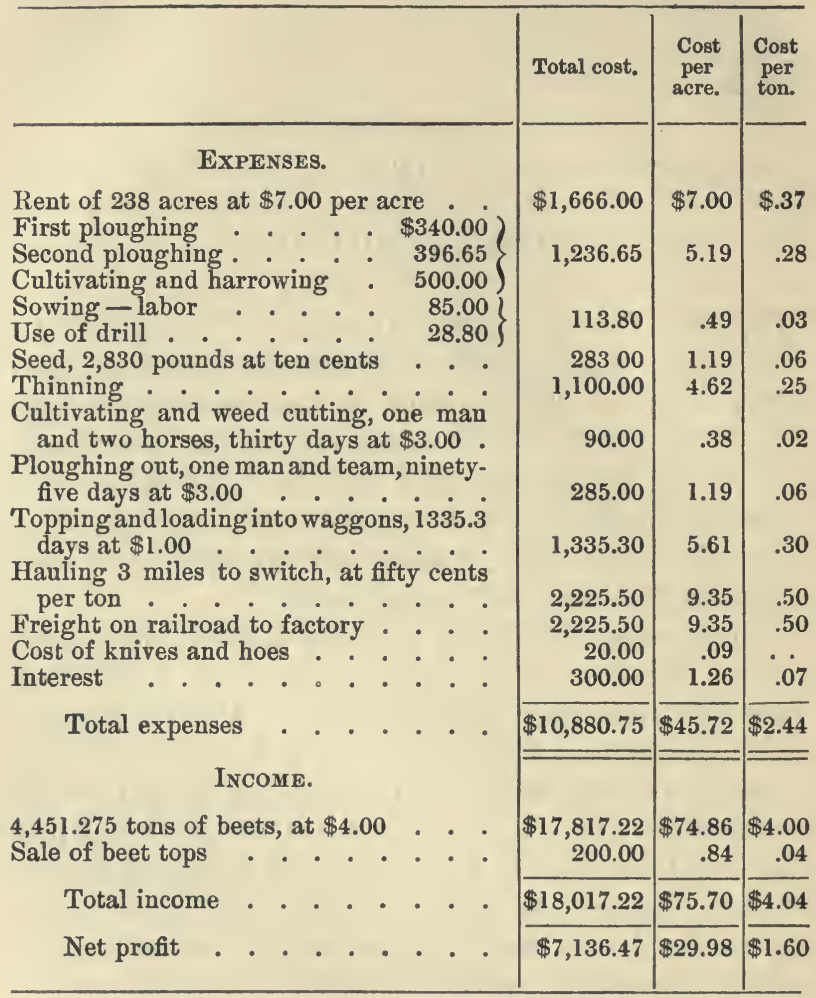

General Chipman, from whose report to the San Francisco Board of Trade I take my facts, goes on to say :-

"California is destined to become the beet sugar plantation of America as it has already become the orchard of America, because pre-eminence must be accorded and must surely come to that State where the conditions necessary to success, both in the growing of the beet and its manufacture into sugar, are most favourable. ... Briefly summarised, these favourable conditions are: earlier maturity of the beet, earlier opening 


\section{Appendices}

of the campaign, longer season for harvesting, longer run of factory, greater yield per acre, greater per cent of saccharine, immunity from frost, immunity from rain at critical periods, and ensilage or 'pitting' of the beets avoided."

The land adapted to beet culture in California extends through the interior valleys from Tehama County in the north to San Diego in the south, and along the entire California sea coast, and in the coast valleys - about 750,000 acres.

Constant cropping to beets is injurious to land, but the rotation of crops and slight fertilisation adjust the losses of potash and lime. According to an authority, land sown to wheat after beets will produce a twofold yield.

The price of the best beet land varies from $\$ 100$ to $\$ 250$ per acre, according to its location. 


\section{V \\ IRRIGATION}

7 HE drought of 1898 taught the people of California 1 the lesson of irrigation. Before the secularisation of the Missions the Padres dug many ditches, and water was carried to their vineyards and orchards from a long distance, involving enormous labour on the part of the Indians, labour in those days being compulsory for the most part. To-day, power will be found cheaper than the systems which bring water to land in obedience to the law of gravitation. In ' 98 we bought and operated two pumping plants which worked admirably; and it must be remembered that when you are dependent upon water supplied by a company from some huge reservoir there is always the grave danger of the water failing at critical times. In the Salinas valley, for instance, gigantic sums were expended in digging canals, but when these were dug, the river from which the water to fill these canals was to be taken, dried up, and the enterprise was temporarily wrecked. There are many parts of California, notably in the counties of Kern, Tulare, and Fresno, where the water obtained from the canals does not fail, but speaking generally it will pay the small farmer to own his own pumping plant.

I cannot do better than quote in full a memorandum on this subject written by Mr. William H. Mills, to whom I am indebted for many courtesies. Mr. Mills is widely known as a brilliant writer upon all subjects connected with the resources and development of California. He says :- 


\section{Appendices}

"Fruit raising, vine growing, and small farming in California will depend for their success in a very great measure upon the artificial application of water. These applications have proven profitable, and will continue to be so under favourable conditions without irrigation, but they are far more profitable with it. Every orchardist and vineyardist ought also to be a gardener, and, in order to diversify the products of the land, irrigation must be resorted to. Clover, berries, gardens, orchards, and vineyards should be found on the same holdings, and should occupy the attention of the cultivator of the soil in their various seasons. This diversity would in a measure equalise the demand for labour throughout the year and greatly improve the labour conditions. Irrigation will enable the orchardist and vineyardist to supply his table with poultry, eggs, milk, butter, vegetables, and fruits, and thus confer upon his holdings its first and paramount duty of affording him a complete subsistence. The problem of living having been solved, the question of profit would become more certain and happily less important.

"The ancient methods of irrigation will be superseded by modern and more economic methods. This revolution will be referable to the cheapening of mechanical power and the increased efficiency of pumping machinery. Under the old method a main canal carrying water at an elevation to lay a certain district under irrigation was necessary. Its construction and maintenance were costly, while the application of water to lateral ditches was also costly and unsatisfactory. A gravity supply of water can be passed over a surface where the decline is constant. There are no lands sufficiently level to make more than 60 per cent of their surfaces subject to irrigation from any point of elevation in their vicinity.

"There are seasons in which the excess of precipitation makes drainage a problem difficult of solution. In such seasons, a costly water system constructed after the old plan of canals with lateral farm ditches is uneconomic as well as useless. The money invested in it earns nothing in such seasons, and as a rule in the country in the northerly portions of the State the level areas have more to fear from excessive precipitation than from drought. 
"If it be suggested in answer to this statement that the summer months are dry months and that the application of water during the heated term will enable the cultivator of the soil to avail himself of the superior productiveness of the summer months, the answer is that the application of water by canals and lateral ditches produces in all countries where the practice has been in vogue swamp conditions on the lowest lands, unless a supplemental costly system of drainage is resorted to, and besides, as already noticed, it cannot be applied to the entire surface of the land.

"Naphtha or gasoline engines have furnished a very cheap power for pumping, while improvements in pumps have made their use far more economic than the application of water by the more primitive and crude method of ditches. Of course, the water must be brought to a point from which it may be pumped economically, and this can be done in three ways: first, by a main canal, which is tapped only with the suction of pumps. Such a canal would cost less and would be more permanent in its construction, because it would not be constructed with reference to supplying water to laterals. Second, by the use of the channels of living streams. For the most part the irrigable lands of California are accessible to streams. Third, by the sinking of wells. Concerning this latter, it should be noted that an irrigated country soon fills with water, and wells in such a country afford an ample supply for such portions of land holdings as need irrigation. The economic use of the pump is also greatly reinforced by the facility with which, in modern times, electrical power is transmitted at cheap rates.

"Some practical experiments in pumping were made in various parts of the State during the drought season of 1898. It is stated on seemingly reliable authority that there are not far from two thousand irrigation pumps in operation in the county of Santa Clara alone. For the most part these are using wells, and their use has proven beneficial and economical.

"In Capay Valley, with irrigating machinery, pumping from Cache Creek was practised and highly satisfactory results obtained. It was found that a six-inch pump, using a fifteen horse-power gasoline engine, was capable of delivering forty- 


\section{Appendices}

two thousand gallons an hour (700 gallons per minute) at the end of an eight-inch pipe two thousand feet in length at an altitude of thirty feet above the surface of the water. This would give two hundred and fifty gallons to each of 168 trees per hour, a little in excess of the equivalent of one inch of rainfall. Ten hours' pumping, allowing 250 gallons to each tree, would give a daily efficiency of the pumping machinery equal to 1,680 trees, or fully sixteen acres a day. Excluding the labour of handling the pipes, which was usually performed by the owner of the orchard, the cost was $\$ 5$ per day. The cash outlay, then, to"the orchardist, excluding his own labour, was $\$ 5$ per day for the application of 250 gallons to each of 1,680 trees through a pipe line two thousand feet in length. At a greater elevation than thirty feet the efficiency of the machinery was reduced. Careful arithmetical observation, however, demonstrated the practicability of supplementing the pumping station at the creek with pumps stationed at the end of the pipe line to reach still higher elevations, and practically demonstrated the superior economy and advisability of pumping as a substitute for ditches. Every portion of an orchard, however uneven its surface, could be reached with the pipe line, and from a single pumping station, where the highest point of the land was below thirty-five feet elevation, approximately 500 acres of alfalfa could be irrigated. The application of 27,000 gallons to each acre could be made for $33 \frac{1}{3}$ cents per acre. This is the equivalent of one inch of rainfall, or the equivalent of three inches of rainfall on each acre could be made for $\$ 1$ per acre; or the application of the equivalent of one inch of rain at three different times in the season for the same sum, not including the labour of moving the machinery or the necessary movement of the pipes over the surface of the land. The experiment brought plainly to view the fact that at below thirty-five feet elevation above the surface of the water the entire cost, including all the labour employed, would be the equivalent of one inch of rain for forty cents an acre, or at most $\$ 1.25$ for the application of this one-inch equivalent three times in a season.

"The machinery used for these experiments was constructed on a truck, movable from point to point, and the result ob- 
tained was very highly satisfactory. Over an accessible surface the water was evenly distributed, and when the irrigation was completed, there was no injurious excess in low places or deficiencies upon the higher elevations of the surface.

"The equipment with which these results were obtained embraced the following: One 15 horse-power gasoline engine, one 6-inch centrifugal Krogh pump, one truck 8-inch tread of tire, three thousand feet of 8-inch wrought-iron pipe with fittings, including priming pump, jack screws, oil tank, and duck cover; and cost $\$ 2,000$.

"The capacity of the equipment was equal to the duty of irrigating throughout the season 500 acres of land, and upon that area would supply all the water necessary for any species of cultivation desired, whether of alfalfa or orchard. Its capacity was equal to 1,200 acres of orchard land, and, as already noted, the original investment was but $\$ 2,000$.

"To recapitulate these conclusions, the experiment in Capay Valley demonstrated that a stationary pump, eliminating the cost of trucks designed to make the equipment portable, with 2,500 feet of pipe, cost less than $\$ 1,500$. For orchard purposes the efficiency would be equal to the duty of irrigating 1,200 acres of orchard or 500 acres of alfalfa throughout the entire summer season, and the application of 135,000 gallons of water to each acre during the season would cost $\$ 1.65$ per acre for the season, not including the labour of moving the pipes; or if the labour of moving the pipes is included, $\$ 1.75$ for the season.

"Aside from the advantages already noted, the superior efficiency of applying the water to the entire surface of the land and the control of the quantity of water placed upon the land, the interest on the original cost of the equipment is to be considered. It is doubtful if, by a canal system, lands anywhere in the State can be laid subject to an irrigation system for less than an original cost of $\$ 10$ per acre, and this original investment would be permanent and the interest element connected therewith would be a perpetual charge against the original equipment. $\$ 10$ an acre for 1,200 acres of orchard would be $\$ 12,000$, or for 500 acres of alfalfa $\$ 5,000$, as against $\$ 1,500$, the original cost of a coefficient pumping plant. 


\section{Appendices}

"The application of electrical power would reduce the cost from the figures herein given. To the estimates relating to the canal system must be added the cost of maintenance, the waste of water by absorption and evaporation, and the very unsatisfactory method of applying the water by gravity.

"It is within reasonable probability that from sixty to seventy-five per cent of the orchards and vineyards of the State could be laid subject to irrigation by pumping at a cost not exceeding that given in this statement.

"This by no means exhausts the subject. All over the State wells of sufficient capacity to supply a three-inch pump on small areas of ten or fifteen acres, using a five horse-power engine, are to be found. There is scarcely a land-holding where an equipment of this kind costing less than $\$ 1,000$ cannot be made available. The application of this cheaper and less ambitious equipment would greatly diversify the agricultural pursuits of the State; would enable cultivators of the soil to beautify their holdings and furnish the full round of home necessities." 


\section{VI \\ HINTS TO SPORTSMEN}

$\mathbf{T}^{\mathrm{T}}$ is a hard saying, but the sportsman in search of 1 game, big or small, must be prepared to encounter what is more grievous to bear than toil and fatigue disappointment. It is almost impossible to get reliable information in regard to game and fish, and the stuff printed in railroad circulars, real estate pamphlets, and most of the magazines, is absolutely untrue. More, a man may be honestly willing and able to give information, and the person to whom it is given may find it worthless owing to some misapprehension on his (the sportsman's) part. I could name half a dozen rivers and streams where the steel-head trout may be caught, and the angler might wet his line in vain on such rivers, because neither I nor any one else could predict exactly when these fish would be running.

Good sea-fishing, however, particularly at Catalina Island, is a certainty. Between the first of May and the first of September the fisherman may confidently count on killing tuna, black-bass, yellowtail, sea-bass, albicore, and bonito, beside many others. This is the only place, indeed, where tuna can be caught. You travel direct to Los Angeles from New York, and Avalon (Catalina's small town) is four hours distant. Here are several hotels, and within a stone's throw of them the stands and boats of the boatmen. Tuna fishing costs from $\$ 5$ to $\$ 7$ a day. For the other fish, a rowing boat (instead of a 


\section{Appendices}

launch) is quite sufficient, and the hire of one with a man to row it is $\$ 3$. Two men can fish comfortably from the sternsheets of these boats, and so divide the cost; or you can hire a boat by the week without a man for a small sum, and row yourself. The boatman supplies everything, including rods and reels; but I take for granted that the sportsman will bring his own tackle. You will need three kinds of rod: a tuna rod, a yellowtail rod, and a light rod for bonito. If economy must be practised, buy no tuna tackle (which is very expensive), for one boatman at least, James Gardner, has excellent rods and reels. I know of only one man who makes a reliable tuna reel, Edwin Vom Hofe, of New York, and his reel is not yet perfect. Upon this reel must be wound three hundred yards of cutty-hunk line, one hundred of twentyfour ply, and the back line of twenty-one. Unless the reel can hold this amount of wet line it is worthless for tuna fishing. The ordinary tarpon tackle will not prove satisfactory for tuna. Hooks can be bought on the island, and all the tuna boatmen have gaffs, although some of them (the gaffs) are not long or strong enough. You can also buy on the island piano wire, and make your own tuna and yellowtail spinning tackle at a price considerably less than half of what is paid for the ready-made article. Cutty-hunk lines are also for sale in Avalon. The rod should not be too stiff, but stiff enough to "pump" the fish when he sulks.

For black-bass you use tuna tackle. For yellowtail, sea-bass, and salmon (not found at Catalina), I have found the ordinary yellowtail rods much too short and too stiff. I commend a lightish spinning rod of split bamboo, and the line (despite the protests of the boatmen) should be fifteen ply cutty-hunk. The reel should hold two hundred yards of this easily. Beware the dealer who shows you a reel which he says will hold 
so much line, and which on trial holds some fifty yards less than you expected.

Take with you a stout box - wood or leather - holding scissors, pincers, a knife, hooks of all sizes, wire, gimp, extra lines, vaseline, file, thread, and the other odds and ends, lack of which interferes so often with comfort and sport. And do not omit from these binding silk, wax, and varnish, for a split bamboo is not proof against salt water, and if injured must be mended at once.

Your ticket to Catalina, allowing for a few days en route, and your expenses between London and Avalon, should not exceed fifty pounds. The rates at the Avalon hotels vary, according to accommodation, between $\$ 2$ and $\$ 6$ a day.

Small-game shooting begins about the first of October, and continues till the end of February. I have already said that it is impossible to get really good duck or quail shooting unless you camp out. The best quail grounds are still to be found in Southern California, but only a market-hunter can take you to them. He will provide everything, but it will be well, in your own interest, to add a few luxuries. You will take a tent, but $I$ advise you to sleep, if possible, in a waggon. My brothers and I always took a light waggon with two horses. The bed of the waggon was filled with hay for the horses, and on this hay we slept. As a general rule it is not necessary to carry much hay, as it can be bought at the ranches at a reasonable price; and farmers, we found, were generally willing to supply us with butter and milk and eggs. Do not sleep in their barns. You will be disturbed by the horses and by fleas, and there is always the danger of fire.

Remember, too, that if the autumn rains have not fallen, the country over which you are shooting is covered 


\section{Appendices}

with grass as inflammable as tinder. A spark burning in an empty cartridge may destroy thousands of acres of feed. You cannot be too careful.

For quail shooting I prefer to use very small shot, No. 8, chilled; and I seldom shoot at a bird that is more than forty yards away. A wounded quail is impossible to find without an exeellent dog, and the best of dogs soon lose their powers of scent on a warm autumn day. After a little practice you will learn to retrieve your own birds. If they are getting up singly one after the other, which often happens, and you have several down in the low sage brush, it is wise to mark the places where you think they have fallen with a cap, a handkerchief, or a glove. Then you circle slowly round these objects, gradually enlarging your circle, overlooking no tuft of grass or bush, and by this method, slow, but sure, you will lose few quail.

I have not given a list of stores, because your markethunter must travel at least twice a week to some point on the railroad whence he can ship the dead birds, and on these occasions he can buy what is needed for the camp. None the less, good hams, bacon, canned jams and vegetables should be purchased in a big town, as the village stores only keep third-rate articles.

Duck shooting is fairly good in Southern California, but excellent in the marshes north and north-east of San Francisco. Here again you will be helpless without a professional hunter, for you must have decoys, dogs, boats, and also that special knowledge of the habits of the birds which only comes after long experience. As I have pointed out, a commission merchant in either Los Angeles, San Francisco, or Portland, will gladly give you the names of half a dozen Nimrods, and he will also tell you who kills the most game - an important thing to know. 
For all these expeditions a waterproof hold-all should take your kit, not the common hold-all, but the large bag, into which, if necessary, you can crawl yourself on a damp night. This will contain two pairs of blankets, a small pillow, a change of clothes and underlinen, extra boots, towels, etc. A small bottle of Chamberlain's Colic Cure (in case you drink unknowingly of alkali water), some quinine pills, and a mild aperient, should not be omitted. .

The cost of such expeditions will be trifling compared to the expense of buying or hiring a complete camp equipage, and paying the wages of a guide. Markethunters work hard, and seldom make more than a bare living, so you will find them only too willing to accept a modest sum of money, better "grub," and the birds you shoot, in exchange for their companionship and a share of their sport. I have often found it difficult to prevail upon such men to accept any money at all.

Big-game expeditions are not lightly to be undertaken, and it is absurd to lay down the law in regard to them; so much depends upon season, locality, and the men themselves. Under certain circumstances you look askance at a tooth-brush, for every extra ounce must be paid for by the sweat of your brow. In the dense forests of the Pacific Slope each man packs on his back his own load, and the lighter the load the lighter the heart of him who carries it. Speaking from experience, I strongly advise the English sportsman to keep out of the woods of Washington, Oregon, and British Columbia, unless he can reach their solitudes by means of a canoe. The chance of shooting a wapiti in the forest is very slim, but the chance of returning from such expeditions absolutely worn out in body and soul is not so small. I shall speak, therefore, of those expeditions which can be made 


\section{Appendices}

either with a waggon or pack animals through a country tolerably open. Such country may still be found in Wyoming, Idaho, Montana, Eastern Oregon, Eastern Washington, and in the uplands of British Columbia ; but I dare not undertake to recommend any particular spot.

Roughly speaking, it is still possible to get wapiti, muledeer, antelope, blacktail, and bears of sorts in the States I have mentioned; but bighorn, wild goat, caribou, moose, and musk-ox must be sought for in British Columbia and Alaska. Mr. Baillie-Grohman suggests the Olympic Mountains of Washington as a likely place for the Pacific coast wapiti, which differs slightly from the "elk" of the Rockies; and into these same mountains I hope to go within a few months, but I cannot as yet claim a personal acquaintance with them. My brother and I were in the State of Washington, close to these mountains, some two years ago, but we were fishing. We learned that parts of the country were open, and that game was plentiful; and we had the pleasure of seeing several fine trophies which had come the year before out of the Olympics.

No matter where you go, however, it is all-important to find a good guide, and from choice-as well as for economical reasons - a trapper is your man; but be sure that he is a trapper and not an impostor, and make it clear to him what you want. In one of my expeditions the bag included bison, bear, bighorn, wapiti, mule-deer, and antelope; hut that was seventeen years ago. When I was in Vancouver Island in '97 I met a friend returning with an Indian from an expedition. He had shot nothing! But then he and his guide had plunged into the forest. The same man shooting the year before in the uplands of the Chilcotin district hacl enjoyed excellent sport with both bighorn and caribou.

The less you take from England in the way of impedi- 


\section{Appendices}

menta the better. We found a camp bucket (sold, I believe, by Silver) very useful, because it contains in a surprisingly small space nearly all you want in the hardware line; and I strongly recommend an air mattress and small indiarubber bath. I have used for many years two rifles, an English Express, 450 cal., and a Winchester repeater. The Express cost fifty guineas, the Winchester a few dollars, and I prefer the latter. The '95 pattern Winchester, 30 cal., shooting the U. S. service bullet, is a wonderful weapon for the price, and extraordinarily effective; but I cannot testify to its effect on big bears, although I am told that the trappers prefer it to a larger bore. Winchester cartridges can be bought everywhere.

Clothing and boots are better made and far cheaper in England; but blankets, tents, cooking utensils, and so forth, can be bought as cheaply in any Western town, and will fetch second-hand a certain sum. It is most important to take the best field-glass that money can buy.

Every sportsman has his own ideas about the commissariat department. Personally, I contend that the more you can conveniently take in the canned goods line the better. Straight meat agrees with very few. Canned corn, canned tomatoes, canned beans and bacon, dried fruits and vegetables, and plenty of cheese, make camp life healthier and cheerier. At any rate, a few cases of these will soften the first rigours of the campaign; and when they are gone, you will be hardened and able to forego such luxuries. In any case, don't stint the sugar. Saccharine matter in some form would seem to be an imperious necessity to a man living the primal life. Chocolate, too, is a wonderful food, and one too often ignored by the sportsman.

I submit a list, beginning, as will be seen, with 


\section{Appendices}

the necessities and ending with the luxuries. The quantity must be regulated by the number in the party and the time you propose to be absent. Your guide can adjust such matters.

Matches.

Flour.

Salt and pepper.

Baking powder.

Sugar.

Chocolate (a large quantity).

Whisky.

Coffee and tea.

Bacon.

Dried onions.

Cheese.

Beans.

Dried potatoes.

Dried apples.

Dried apricots.

Dried prunes.
Lard.

Dried fish (smoked salmon, etc.). Crackers.

Raisins (cheap and good food).

Keg of Syrup.

Oatmeal.

Canned vegetables.

Canned fruits.

Jams and marmalades.

Hams.

Tinned turkey, chicken, game, etc.

Tinned milk and cream.

Tinned soups.

Keg of butter.

Pickles.

I omit tobacco, because those who smoke will never leave the blessed weed behind. Whisky must be kept under lock and key if Indians be of the party. To most trappers strong drink is irresistible, and on that account many sportsmen take only sufficient for medicinal purposes. If you camp out in the winter, bacon and lard are necessities, and much more warming than alcohol.

I have spoken already of the sleeping bag, but I would urge the tyro once more to take plenty of warm bedding if he intends to brave the snows and frosts of the Far North. At a sharp pinch, you can sleep in gum boots and mackintosh. This, I need hardly say, is a last resource against the most piercing cold.

You can buy at the Army and Navy Stores a small leather medicine case, which contains a few drugs in portable form.

Englishmen are outrageously robbed when they begin to buy horses, mules, waggons, saddles, etc. Find out the market price of what you want: information cheer- 
fully given by any respectable citizen not directly or indirectly concerned with the sale. At such times good letters of introduction are invaluable. The men at the head of big enterprises, the railroad people, the bankers, the contractors, will take particular pains to see that the stranger within their gates is not swindled, provided always that you appeal to their sense of hospitality. It is possible to buy an "outfit," use it for six months, and sell it for nearly as much as you gave; but such a piece of luck falls to few.

In conclusion, I emphasise once more the expediency of borrowing experience. In Victoria, in Tacoma, in Seattle, in Portland, and in San Francisco, men may be found whose advice will save you not only money, but time and trouble. Most Englishmen are so desperately anxious to start into the wilderness that they grudge every minute spent in making inquiries. Such greenhorns nearly always return empty-handed, because they go emptyheaded. Long before we start on even small expeditions, my brothers and I begin to make careful notes. For instance, it is folly to take horses into a country where the feed is short; it is absolutely necessary to know something of the topography of the district you wish to bunt in : its rivers and streams, its mountains, woods, and trails (if any). You are sure to pass through many big ranches, and a letter to the owners will insure you a welcome at least. If you can do no better, a card from one of the merchants may prove an open sesame to priceless stores of information.

It is perhaps superfiuous to remind the sportsman that around the camp-fire all men are equal. And remember that, be they many or few, your hired companions will take their tone from the "boss." If you whine, so will they ; if you curse, so will they; if you loaf, so will they. Insist from the first upon order and cleanliness. Each 


\section{Appendices}

man should have certain definite duties, duties never to be shirked; and it is amazing how quickly these duties are performed after a little practice.

In regard to the preservation of your heads, a hint or two may not come amiss. In the dry uplands, scrape the skins free of flesh and fat, and dry them in the sum. The skulls can be sawn in two. See to it that the skin around the necks of the deer and wapiti is preserved; and be sure that the slit is at the back of the neck, so that the trophies when mounted will show no ugly seam. The appearance of many a fine head has been spoiled, because it was cut off too near the skull, and the skin slit below the neck. In the lowlands, where it may be hot and damp, it is necessary to use either pepper and salt or some preserving mixture. 




THIS BOOK IS DUE ON THE LAST DATE STAMPED BELOW

AN INITIAL FINE OF 25 CENTS WILL BE ASSESSED FOR FAILURE TO RETURN THIS BOOK ON THE DATE DUE. THE PENALTY WILL INCREASE TO 50 CENTS ON THE FOURTH DAY AND TO \$1.00 ON THE SEVENTH DAY OVERDUE.

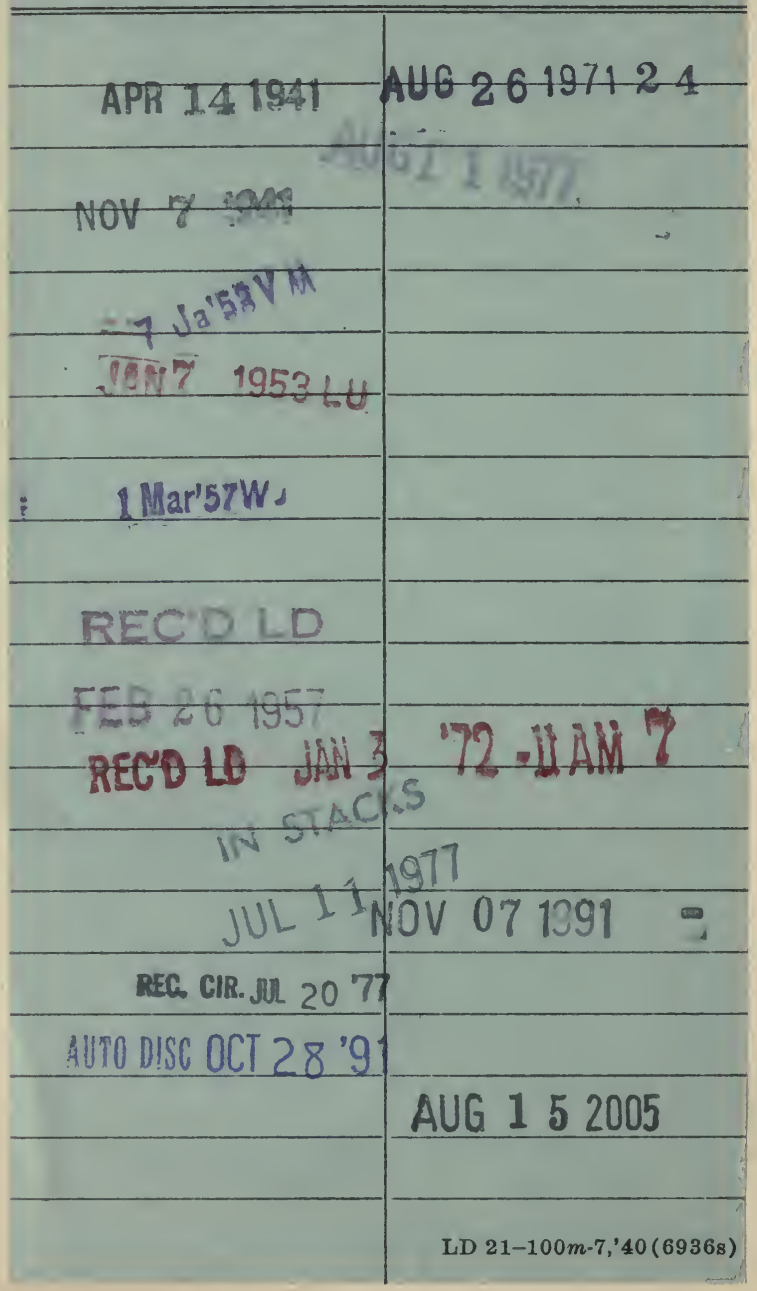


U.C. BERKELEY LIBRARIES

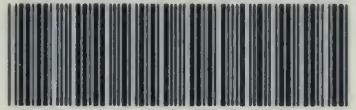

c038505270

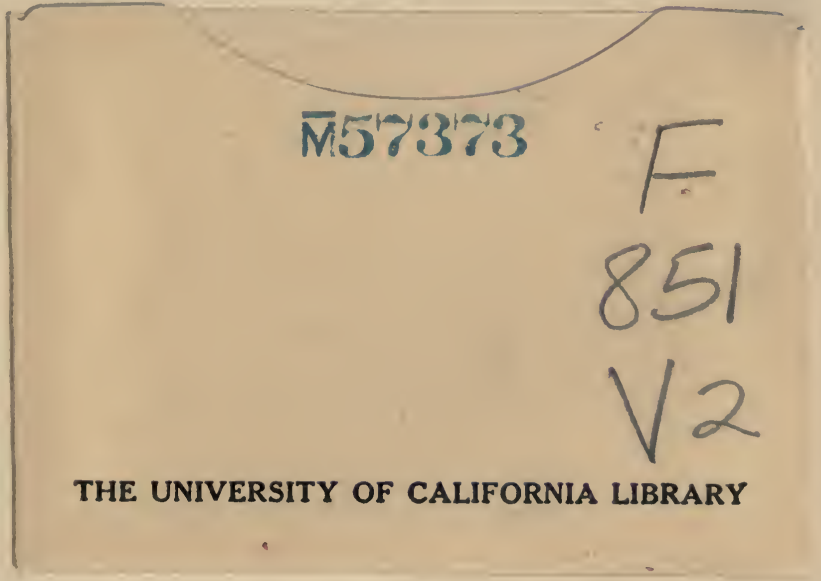


